Faculdade de Arquitetura e Urbanismo da Universidade de São Paulo

Mário de Andrade colecionador: olhar para além de seu tempo

Bianca Maria Abbade Dettino 


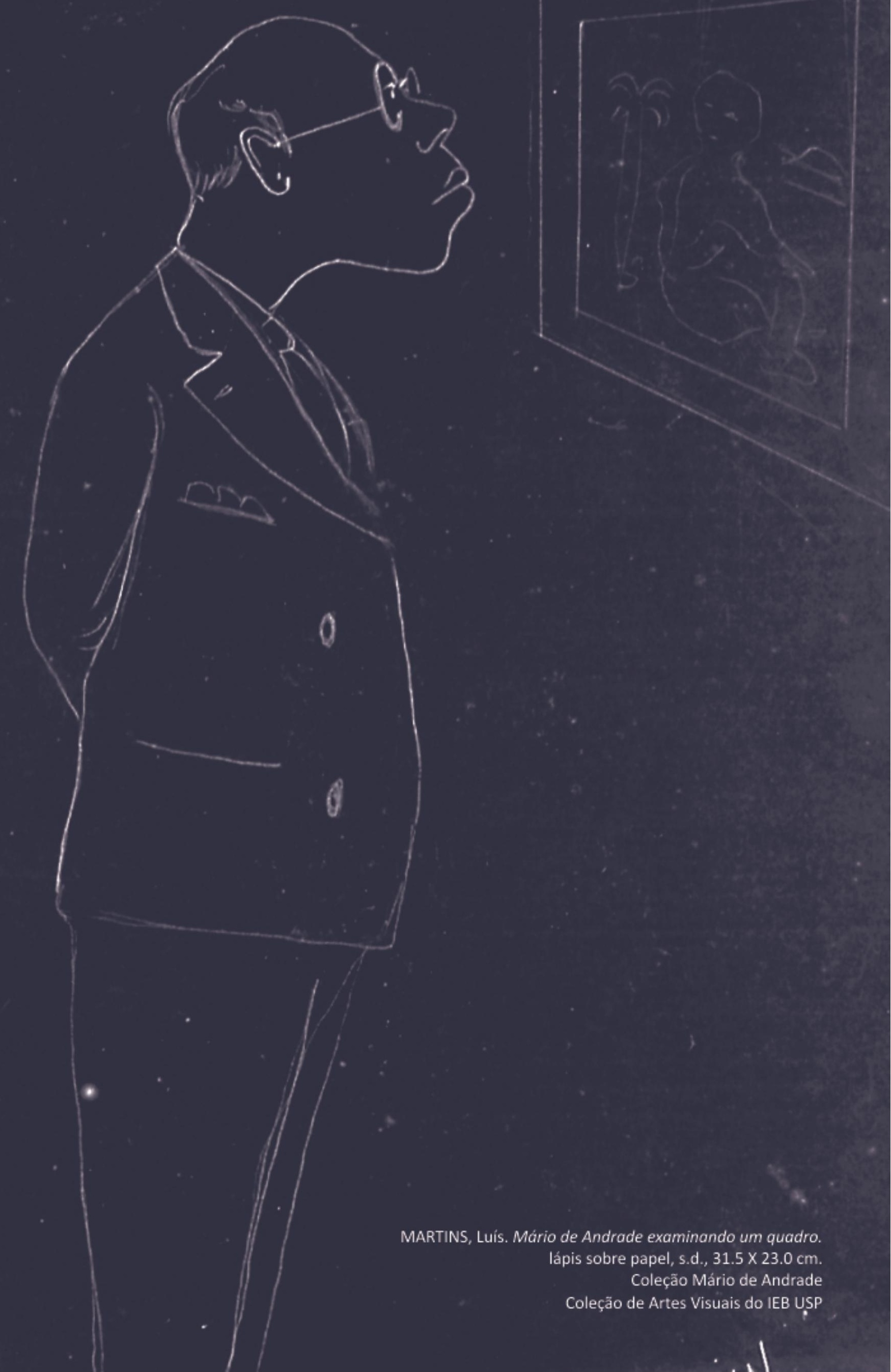




\title{
Mário de Andrade colecionador: olhar para além de seu tempo
}

\author{
Bianca Maria Abbade Dettino
}

Orientadora: Profa Dra Maria Cecília França Lourenço

Dissertação de Mestrado

Área de concentração: História e Fundamentos

da Arquitetura e do Urbanismo

Linha de pesquisa: Museu / Patrimônio

Faculdade de Arquitetura e Urbanismo da Universidade de São Paulo São Paulo, fevereiro de 2012 
Autorizo a reprodução e divulgação total ou parcial deste trabalho, por qualquer meio convencional ou eletrônico, para fins de estudo e pesquisa, desde que citada a fonte.

e-mail: biancade@usp.br

Dettino, Bianca Maria Abbade

D483m Mário de Andrade colecionador: olhar para além de seu

tempo / Bianca Maria Abbade Dettino. -- São Paulo, 2012.

177p.: il., CD-Rom

Dissertação (Mestrado - Área de Concentração: História e Fundamentos da Arquitetura e do Urbanismo) - FAUUSP

Orientadora: Maria Cecília França Lourenço

1.Artes plásticas - Século 20 - Brasil 2. Modernismo - Brasil

3.Coleções - Brasil 4.Andrade, Mario de, 1893-1945. I. Título

CDU: $73 / 76(81)$ 
Para Marinel e Rinaldo,

Aldo e Ricardo,

em especial minha mãe.

Em memória de Marta Rossetti Batista 


\section{Agradecimentos}

Em primeiro lugar agradeço às instituições consultadas nessa pesquisa: Cinemateca Brasileira - Centro de Documentação e Pesquisa - Biblioteca Paulo Emilio Salles Gomes, na figura de Alexandre Miyazato; Oficina da Palavra Casa Mário de Andrade, a Rosa Artigas e Grace Laine Pincerato Carreira; Fundação Maria Luisa e Oscar Americano, a Claudia Vada Souza Ferreira. À Biblioteca da FAU USP, nas figuras de Valéria Valente, Maria José Polletti e Paola de Marco Lopes dos Santos.

Ao generoso depoimento do Prof. Antonio Candido, incentivador incondicional da pesquisa, esclareceu pontos fundamentais para a compreensão do uso da casa de Mário de Andrade; além de, carinhosamente, convidar-me para acompanhá-lo no almoço. Essa entrevista só foi possível graças à oferta da Prof.a Marina Mello e Souza, a quem agradeço.

À Banca de Qualificação, que para além do papel de examinadores são parceiros de trabalho, Prof. Marcos Antonio de Moraes, cuja profundidade com que trata o tema é digna de entusiasmo, e Prof.a Ana Lúcia Duarte Lanna, que admiro pela acuidade na análise sistêmica do trabalho acadêmico e, também, pelos anos de convívio, incentivo e debate no IEB.

Aos professores Pós-Graduação da FAU USP, representados pelos professores Julio Roberto Katinsky e Luiz Américo de Souza Munari, que contribuíram em várias etapas desta pesquisa.

À Secretaria da Pós-Graduação e do Departamento de História da FAU, nas figuras de Silvia Freitas dos Santos e Rosemary Conceição Cruz, personagens fundamentais ao bom andamento do trabalho.

Às colegas da arquitetura, ainda na graduação, Júlia Rozo Perez Ferrari e Camila Ismerim Lacerda, que participaram da reconstrução da casa, a de Mário.

Ao Instituto de Estudos Brasileiros, que poderia estar no elenco de instituições examinadas, mas que coloco destacado, por ultrapassar os limites da consulta, uma vez que é, também, objeto de estudo e local em que exerço minhas atividades profissionais. Neste sentido, agradeço à atual diretora, Prof. a Maria Angela Faggin Pereira Leite. Cito também o diretor, entre 1998 e 2002, Prof. Murillo Marx (em memória) que sugeria rasgar os diplomas, apenas depois de alcançá-los.

À Biblioteca e ao Arquivo do IEB, que compreendiam as solicitações mais detalhistas, atendendo a todas com curiosidade e entusiasmo, nas figuras companheiras de Marita Causin e Márcia Pilnik; e, Elisabete Marins Ribas e Mônica Aparecida Guilherme da Silva Bento, respectivamente.

À Coleção de Artes Visuais, por estar "ali do lado", nas figuras de Dorivaldo Santana de Almeida e Leonildo Oliva de Araújo; e, também, dos estagiários, fiéis escudeiros, Marília Senlle, Wanderson Rezende, Roberta Lopo Bezerra e Thiago Folador.

Aos colegas e amigos de trabalho, Marlene Lúcia de Aguiar - que zela pela preservação do Arquivo Permanente -, Maria Inês Bento, Rubens Borges Pinto, Marcos Lopes, Márcia Dias, Tatiana Longo Figueiredo e Maria Célia Amaral.

Aos colegas do Grupo de Estudo sobre Museus e Patrimônio: Lisete Hanna, Paulo Barbosa, Mariana Dupas, Raquel da Costa Nery, Adrienne Firmo, Anna Rahme, Ethel Leon, 
Renata Motta, Hélio Herbts. Em destaque, à Ana Paula Nascimento, por estar presente em vários momentos desta pesquisa.

Aos queridos amigos, de estudo e de trabalho, Ana Rosa da Silva, Rogério Wagner, Ciça Winter, Nalú Medeiros, Bia Cavalcanti, Carol Boaventura, Ana Paula Lima.

Aos amigos de sempre Luiz "Feijão" Marcomini, Augusto César Rodrigues, Marcos Cardinale, Patrícia de Sá Romancini, Carla Gilbertoni, Fernando Lopes Abbade, Juliana Rinaldi Abbade, Orlando de Marco, Lidiane de Oliveira, Maria Izilda Fonseca Leitão. E, com especial afeto, carinho e admiração, a Lúcia Elena Thomé. A Daniel Cóstola, pela "casa do oscar". A Rafael Florêncio da Silva, pelo carinho.

Destaco os agradecimentos, a Elly Rozo Ferrari e a Dina Elisabeth Uliana, como incentivadoras desse trabalho, além da amizade diária.

À Denise Yamashiro, madrinha que até hoje exerce o papel, topando inclusive rever partes deste trabalho em tempo recorde.

Aos meus pais, Marinel e Rinaldo, terra firme e segura. Aos de casa, Aldo e Tathi, Ricardo e Adriana, meus fofos: Amanda, Diego, e àquele que já está a caminho.

Ao Thiago Lima Nicodemo, cuja presença tornou todo o processo bem mais leve, tranquilo e alegre.

À minha orientadora, Profa. Maria Cecília França Lourenço, Ciça como custei a chamála, talvez minha maior incentivadora, sem a qual este trabalho não seria possível. 


\section{Resumo}

Este estudo se dedica à compreensão dos caminhos distintos da coleção de artes plásticas, reunida e mantida por Mário de Andrade, ou seja, uma espécie de, vir-a-ser do conjunto, desde sua casa até a Universidade de São Paulo (USP). Ao ser expostas a diferentes, olhares, estudos e interpretação concretiza uma meta do escritor, sendo hoje preservada pelo Instituto de Estudos Brasileiros da Universidade de São Paulo (IEB-USP). No processo constitutivo desta coleção, contam-se diversas etapas, desde as primeiras aquisições do colecionador até sua incorporação pela Universidade.

Ao longo deste trabalho, pode-se observar que o processo de formação da coleção se dá na relação entre o privado, os desígnios pessoais do colecionador, e o público, momento em que a coleção ganha significado enquanto tal e se destina ao olhar anônimo ou de estudiosos. Pode parecer erroneamente que se trata de uma divisão entre vida e morte de Mário Andrade, contudo esta relação já está presente desde os primeiros passos do colecionador.

Para isso, esta dissertação está estruturada em três capítulos que funcionam como afunilamento do olhar, ante a coleção de Mário de Andrade. A primeira escala, mais ampla, dá conta das expectativas do colecionador, que possuía o desejo expresso de deixá-la para a posteridade, em instituições de cunho público, que veio ao encontro do objetivo institucional relativo ao Acervo do IEB. Já uma escala intermediária é o entendimento dessa coleção como detentora dos valores modernistas, levada ao olhar na Lopes Chaves; e, por fim, a escala mais detalhada, que reconstrói a exposição dessas no espaço da casa.

Palavras-chave: Mário de Andrade, coleção, movimento modernista, casa, Instituto de Estudos Brasileiros. 


\begin{abstract}
The purpose of this study is to further understand the developments of Mario de Andrade's art collection from the period when it was available at the collector's home to its transfer to the custody of the Institute of Brazilian Studies - University of São Paulo (IEB USP), thereby fulfilling Andrade's will to expose his legacy to different perspectives, studies and interpretations. The process that defined the collection may be divided into distinct phases, from early acquisitions to their incorporation into the University. This thesis emphasizes the relationship between the private sphere - or the collector's purposes and aspirations - and the public sphere - namely, the collection, understood as an independent unit and destined for public appreciation. It could be mistakenly taken for granted that this analysis is based on the assessment of the collection's development before and after Mario de Andrade's death, but public and private relations actually characterize the collection since it's beginning.

The study is presented in three chapters, by narrowing down the subject matter in correspondent levels. The first one, conceived in a wider scale, takes into account the institutionalization of the collection. The second chapter, in turn, analyzes São Paulo's city by the owner of the collection. Finally, the third analyses the disposition of the objects in his house, through a reconstitution of the space
\end{abstract}

Keywords: Mário de Andrade, collection, modern movement, house, Institute of Brazilian Studies 


\section{Lista de ilustração}

\section{Imagens}

Imagem 1. BASSI, Torquato. Lagoa tranqüila. óleo sobre tela, $72.5 \times 84.0 \mathrm{~cm}$. 37

Imagem 2. Cabeça de Cristo de Victor Brecheret, 1919/20 c., bronze, $32.0 \times 14.0 \mathrm{~cm}$. 40

Imagem 3. Paisagem com igreja de Richard Seewald, gravura em metal sobre papel, $17.6 \mathrm{X}$

$13.7 \mathrm{~cm}$. 41

Imagem 4. [Natureza morta] de Juan Gris.

Imagem 5. Casa da Rua Aurora.

Imagem 6. Esquina da Rua Lopes Chaves, com a Rua Margarida, 2011.

Imagem 7. Jardim frontal da Casa da Rua Lopes Chaves, 13 out. 1927.

Imagem 8. WASTH RODRIGUES, José. Fim da rua Direita em 1862 (Igreja de Santo Antônio), 1935. guache sobre papel, $22.8 \times 32.0 \mathrm{~cm}$.

Imagem 9. WASTH RODRIGUES, José. Rua Direita, esquina da rua São Bento em 1886, 1935. guache sobre papel, $25.0 \times 33.8 \mathrm{~cm}$.

Imagem 10. AITA, Zina. Retrato de Mário de Andrade, 1923. nanquim sobre papel, 28.1 X 21.9 $\mathrm{cm}$.

Imagem 11. AMARAL, Tarsila do. São Paulo, 1924 c. tinta de caneta sobre papel, 26.8 X 23.8 $\mathrm{cm}$.

Imagem 12. ANDRADE, Mário de. Paulicéia Desvairada (estudo de capa), s.d. tinta de caneta e lápis de cor sobre cartolina, $31.0 \times 25.0 \mathrm{~cm}$.

Imagem 13. DI CAVALCANTI, Emiliano. Paulicéia Desvairada (projeto para capa), 1921 c. nanquim e guache sobre papel, $25.0 \times 16.2 \mathrm{~cm}$.

Imagem 14. Capa publicada de Paulicéia Desvairada, desenho de Guilherme de Almeida. 57

Imagem 15. CENNI, Franco. Casario, 1939. óleo sobre tela, $55.0 \times 75.0 \mathrm{~cm}$. 58

Imagem 16. Pavilhão de Arte Moderna de Dona Olívia Guedes Penteado, 1925.

Imagem 17. e 18. Pavilhão de Arte Moderna de Dona Olívia Guedes Penteado, 1925 e posterior.

Imagem 19. Salão de Tarsila do Amaral, 1929.

Imagem 20. Entrada da Lopes Chaves, 2011.

Imagem 21. Porta de entrada da Lopes Chaves, 2011.

Imagem 22 e 23. De BRECHERET, Victor, Composição com dois nus, 1924 c., lápis sobre papel,

24.7 X $16.0 \mathrm{~cm}$ e Pietá e Composição - nu feminino com leques, 1924 c., lápis sobre

papel, $19.5 \times 15.1 \mathrm{~cm}$. 73

Imagem 24. Composição cubista de IOKANAAN, Joaquim Alves, 1932, lápis sobre papel, $24.0 \mathrm{X}$ $23.4 \mathrm{~cm}$.

Imagem 25 e 26. Cômodo do estúdio e móvel do hall manuseado pro Zé Bento, do andar superior.

Imagem 27. O mamoeiro, de Tarsila do Amaral, com moldura de Pierre Legrain 76

Imagem 28. Vista do vestíbulo.

Imagem 29. Vestíbulo da Lopes Chaves, com destaque para o porta-chapéu e a escultura Mãe e filho. $\quad 85$

Imagem 30. Vestíbulo da Lopes Chaves, vista de quem sai da casa. 85 
Imagem 32. Vista da saleta de piano. 87

Imagem 33 e 34. Vistas da sala de música. $\quad 88$

Imagem 35. Sala de música - piano e obras de arte. $\quad 88$

Imagem 36. Ludwig van Beethoven de ORLIK, Emil, s.d., gravura em metal sobre papel, $57.0 \mathrm{X}$ $38.5 \mathrm{~cm}$.

Imagem 37. Cabeça de Cristo de Brecheret, sob o piano da sala de música. Acima Ludwig van Beethoven.

Imagem 38. Vista das obras expostas, próximas ao piano, na sala para ensino de música. 90 Imagem 39. MONTEIRO, Joaquim do Rego. Nice, 1923. óleo sobre madeira, 46.2 X $33.2 \mathrm{~cm} .91$ Imagem 40. FERRIGNAC, Ignácio da Costa Ferreira. Colombina, s.d. nanquim, aquarela e colagem sobre papel, $28.0 \times 13.8 \mathrm{~cm}$. 91

Imagem 41. MOURÃO, Noêmia. Soirée de família, 1934/35 c. óleo sobre tela, 21.8 X 27.0 cm.91 Imagem 42. CORREIA DA COSTA, Ignês Maria Luísa. Mulher de chapéu vermelho, 1938. óleo sobre tela, $41.5 \times 34.0 \mathrm{~cm}$.

Imagem 43. REBOLO Gonsales, Francisco. Paisagem, s.d. óleo sobre cartão rígido, $13.0 \times 17.5$ $\mathrm{cm}$.

Imagem 44. Acréscimo de obras acima do piano. Cópia de Los Borrachos de Goya, sem identificação de autoria, s.d. óleo sobre madeira, $25.1 \times 15.8 \mathrm{~cm}$. 92

Imagem 45. Vista da sala de visitas $1 . \quad 93$

Imagem 46 e 47. Sala de visita com piano como focal e paredes adjacentes. 93

Imagem 48 e 49. Paisagem - canto de rua com palmeiras de ROSSI OSIR, Paulo Cláudio, 1927, óleo sobre tela, 38.8 X $46.5 \mathrm{~cm}$ e Marinha de COSTA, Mário Navarro da, 1915, óleo sobre madeira, $20.3 \times 30.7 \mathrm{~cm}$.

Imagem 50 e 51. Destaque para estante de objetos dos mais variados, santos católicos, exvotos, objetos indígenas, de culto afro-brasileiro, cuias, figas, bois, entre outros. 95

Imagem 52 e 53. Auto-retrato de PANCETTI, José (Giuseppe Gianinni), 1940, óleo sobre tela, $49.2 \times 38.2 \mathrm{~cm}$ e Auto-retrato de MALFATTI, ANITA Catarina, 1922, pastel sobre cartão rígido, $36.5 \times 25.5 \mathrm{~cm}$. 96

Imagem 54. Vista da sala de visitas 2.

Imagem 55. Cavalete no canto da sala e no canto superior direito A estudante russa, de Anita Malfatti.

Imagem 56. A estudante russa de MALFATTI, ANITA Catarina, óleo sobre tela, 1915 c., 76.0 X $61.0 \mathrm{~cm}$.

Imagem 57 e 58. Disposição da coleção e estante em um dos cantos da sala de visitas. 98

Imagem 59. O engraxate e o jornaleiro, ou Contando a féria, bronze. 99

Imagem 60. O jornaleiro, CIPICCHIA, Ricardo, s.d., madeira, $35.5 \times 10.5 \mathrm{~cm}$. 99

Imagem 61. Oxê de Xangô, Paraíba (João Pessoa), 1938, escultura em madeira polida, 22.9 X $6.2 \times 6.2 \mathrm{~cm}$.

Imagem 62 e 63. Descida da cruz, GOMIDE, Antônio Gonçalves, s.d., óleo sobre tela, $55.3 \mathrm{X}$ $33.0 \mathrm{~cm}$ e Rosto feminino, BRECHERET, Victor, década de 30, séc. XX, terracota, $24.5 \times 14.5 \mathrm{~cm}$. 
Imagem 66. Para comparar o Arlequim de Mário, reproduziu-se Paulo Arlequim de Pablo Picasso, 1923/24, óleo sobre tela, 92.1 X $73.6 \mathrm{~cm}$. The Nahmad Collection, 2011 ProLitteris, Zurich.

Imagem 67. Vista do hall entre a sala de visitas e de jantar.

Imagem 68. Sebastiana de Campos e Silva, Tana, cozinheira da Lopes Chaves desde 1925. No plano de fundo a direta, a obra Vaso com flores.

Imagem 69 e 70. Sinais que nos permite observar figura por de trás da pintura e Vaso com flores de GUIGNARD, Alberto da Veiga, 1933, óleo sobre cartão rígido, 41.5 X 34.0 $\mathrm{cm}$.

Imagem 71. Vista da sala de jantar.

Imagem 72, 73 e 74. Disposição das obras e do mobiliário da sala de jantar.

Imagem 75 e 76. De REBOLO Gonsales, Francisco, Paisagem com espantalho óleo sobre tela, s.d., 40.0 X $50.3 \mathrm{~cm}$ e Paisagem com casas, 1940, óleo sobre tela, $73.5 \times 92.5 \mathrm{~cm} .108$

Imagem 77, 78 e 79. Cebolas de ADAMI, Hugo, 1926 c., óleo sobre tela, $43.5 \times 54.3 \mathrm{~cm}$, Peixes de BIANCO, Enrico, 1940, óleo sobre tela, 46.0 X $55.5 \mathrm{~cm}$ e Natureza-morta de MALFATTI, ANITA Catarina, 1925 c., óleo sobre tela, 54.6 X $65.4 \mathrm{~cm}$.

Imagem 80. Vista de quem sobe as escadas.

Imagem 81. Retrato de Mário de Andrade de FIGUEIRA Júnior, Joaquim Lopes, 1938 c., bronze, $34.5 \times 20.0 \times 26.5 \mathrm{~cm}$.

Imagem 82. O Futebol de Lhote na parede da escada da casa de Mário de Andrade.

Imagem 83, 84 e 85. LHOTE, André, Futebol, óleo sobre tela, pertencera a Mário de Andrade; Futebol, óleo sobre tela. Outra versão da mesma tela do colecionador; e, LHOTE, André, Futebol, desenho.

Imagem 86. Vista do hall da escada.

Imagem 87. Zé Bento manuseia o fichário analítico constituído de fichas guardadas em envelopes.

Imagem 88 e 89. Móvel para o fichário analítico, que acondicionava algumas telas e, possivelmente suas pastas de couro com papéis flexíveis.

Imagem 90. Vista da antessala do estúdio.

Imagem 91. Vista de quem entra para o estúdio.

Imagem 92. Vistas para a porta do estúdio.

Imagem 93. Vista do estúdio.

Imagem 94. Vista do estúdio.

Imagem 95. Vista do estúdio.

Imagem 96. Vista do estúdio.

Imagem 97. Vista da cama no quarto de Mário de Andrade.

Imagem 98. Mário de Andrade fotografado, em seu estúdio, entre seus alunos: Carlos Ostronoff, Sônia Stermann e Oneyda Alvarenga, [1934].

Imagem 99. Mário de Andrade e A colona, de Cândido Portinari, no apartamento da Glória, RJ, 1938.

Imagem 100. Mário de Andrade e O mamoeiro, de Tarsila do Amaral, no apartamento da Glória, RJ, 1938.

Imagem 101. Mário de Andrade e as obras Soirée de família de Noêmia Mourão e seu Retrato por Lasar, no apartamento da Glória, RJ, 1938. 
Imagem 102. Mário de Andrade em sua mesa de trabalho, em que à esquerda está seu Retrato por Lasar, no apartamento da Glória, RJ, 1938.

Imagem 103. A esquerda em pé, Mário de Andrade veste chapéu, com Antonio Carlos Couto de Barros, Rubens Borba de Moraes, Yan de Almeida Prado, Tácito de Almeida, em casa de Baby e Guilherme de Almeida, [1922]. É notório que quase todos os homens adornam o bolso do paletó com lenço.

Imagem 104. Recibo da Casa Primor, datado de 4 de maio de 1943.

Imagem 105. Projeto do robe de chambre.

Imagem 106. Mário de Andrade de pijama em Natal, 5 jan. 1929.

Imagem 107. Yan de Almeida Prado em robe de chambre.

Imagem 108 e 109.. Retrato de Horace Vernet (1789-1863), editor musical e Retrato de Léon Escudier (1821-1881), estudioso de música. Executado por Dantan, Jean Pierre (dito Dantan Jeune), terracota, 1832 e 1841, respectivamente.

Imagem 110. Yan de Almeida Prado em robe de chambre.

Imagem 111. Manuel Bandeira, 9 out. 1940.

Imagem 112. Manuel Bandeira de pijama, segurando livros, entre eles Dia Garimpo, de Julieta Bárbara lançado em 1939.

Mapa

Mapa 1. Mapa topográfico de São Paulo, destaque para as casa de Mário: Rua Aurora; Largo Paissandu e Rua Lopes Chaves. Destaque também para os salões de Dona Olívia, Tarsila do Amaral.

\section{Plantas}

Planta 1 e 2. Desenho do térreo e do primeiro andar, Rua Lopes Chaves, por Antonio Candido. SV - sala de visitas, SJ - sala de jantar, SH - sala do harmônio, B - biblioteca, ES estúdio, Q - quarto.

Planta 3. Térreo da Rua Lopes Chaves. 
1. POUSO FINAL DOS SONHOS 21

No regaço duma casa de cultura 23

Desejos e intenções às coisas desta terra 28

Destino da sua coleção: uma Universidade $\quad 31$

Gênese do colecionador 34

Prefácio Interessantíssimo da coleção $\quad 39$

O colecionador e a salvaguarda de valores 42

2. CASAS E LUGARES QUE FALAM DE MÁRIO 49

Esses nomes de rua das casas de Mário $\quad 51$

A Paulicéia de Mário $\quad 54$

Espacialidade do movimento dos salões $\quad 58$

Nesta rua Lopes Chaves, a coleção de Mário 65

Bônus com ônus de uma coleção 71

3. MÁRIO ENTRE SUAS COISAS DA TERRA 80

Mário e as lembranças expostas ao olhar $\quad 82$

Vestíbulo $\quad 84$

Saleta de piano $\quad 87$

Sala de Visitas $\quad 93$

Hall intermediário entre sala de visitas e de jantar 104

Sala de Jantar 106

Intervalo entre espaços $\quad 109$

Primeiro andar 113

Estúdio distribui os objetos $\quad 117$

Mário como fruidor de suas coisas da terra 123

Indumentária de Mário e a construção do

homem público 128

$\begin{array}{ll}\text { CONSIDERAÇÕES FINAIS } & 134\end{array}$

REFERÊNCIAS BIBLIOGRÁFICAS

Livro 138

De Mário de Andrade $\quad 140$

Sobre Mário de Andrade $\quad 141$

Catálogos 142

Obras de Referência 143

Sítios consultados 143 
Filme

Documentação

144

Correspondência do Fundo Mário de Andrade

144

Documentos não publicados

145

Processo

145

Filme

145

Entrevista

145 
Nunca estará sozinho.

Nunca estará sozinho. A estação cinqüentenária Abre a paisagem ferroviária

Graciano vem comigo.

Nunca estará sozinho.

É tanta luz formosa, Tanto verde, tanto cor-de-rosa, Anita vem comigo.

Nunca estará sozinho, Artigas ali na Escola, Sargentos, Yan? Me pede esmola $O$ rancor do inimigo.

Todo o nordeste canta, Zé Bento vem comigo, Confissões na garganta, Nunca estará sozinho.

A Ponte das Bandeiras Indaga das remotas Zonas, imaturas zonas, Meu sinal do Amazonas...

Nunca estará sozinho! Nem há noite que o salve Da angústia que o dissolve

Em amigos e inimigos.

Lira Paulistana, 1945 Mário de Andrade 
INTRODUÇÃO 
ste estudo possui como tema a relação existente entre a construção da memória de Mário de Andrade por si mesmo, ainda no calor da hora, e o movimento das formas, por ele denominado coisas da terra, até chegar ao regaço duma casa de cultura, a partir da sua coleção, em especial a de artes plásticas, com intuito de explicitar a conexão do colecionador que com muito esforço adquiriu e reuniu objetos, na atualidade referência obrigatória em livros, manuais, estudos e exposições.

Tal como definida por Krzysztof Pomian, a coleção como conjunto simbólico destinado ao olhar é dotada de personalidade própria que se ajusta aos esforços de Mário de Andrade em constituir sua própria história, com o intuito em comum de sociabilizá-la na esfera pública. O percurso do vir a ser, do tornar-se coleção, perpassa as diversas temporalidades e espacialidades, colaborando igualmente para que sejam desnaturalizadas, pois, o contrário, se imaginar que sempre estiveram no Instituto de Estudos Brasileiros da Universidade de São Paulo (IEB USP), como marcos de uma história da arte postular revela que sejam desnaturalizadas amálgamas redutores da obra de arte como simples objeto de fetiche.

A trajetória de Mário de Andrade foi marcada pelo desejo de institucionalização da cultura no âmbito da esfera pública. Projeto parcialmente alcançado durante o período que esteve na direção do Departamento de Cultura, mas que fora levado a cabo, na esfera do privado, pela sociabilidade de suas atuações, pela fortuna cultura em suas correspondências, ou ainda pela maneira que expunha sua coleção de arte em sua casa na Rua Lopes Chaves. 0 movimento entre privado e público é constitutivo da própria coleção, que agora se encontra na Universidade de São Paulo.

Para além de obras autônomas e independentes, o estudo do conjunto formado pela coleção revela o desejo explícito e intencional do poeta de Paulicéia Desvairada em deixar para a posteridade, como possível leitura, afirmação e herança cultural pública da sua participação, enquanto figura protagonista do movimento modernista. Nesta direção, é fundamental a destinação pública do seu legado material, que veio ao encontro dos objetivos institucionais, reafirmado por gerações de estudiosos do Instituto de Estudos Brasileiros, receptor e intérprete deste precioso acervo.

O recorte adotado, para o estudo do colecionismo do escritor de Macunaíma, foi a exposição ao olhar de suas obras de artes plásticas, em sua casa na Rua Lopes Chaves, o que permite identificar a sua multiplicidade de interesses e a construção intencional de sua própria imagem pública e, por analogia, da sua coleção, para além de seu tempo. A coleção revela ênfases, lutas, alegrias e exílio de dada personagem, que então se humaniza, sendo aqui entendida como uma cultura material a ser ensinada, pesquisada e extrovertida.

Mário de Andrade deixou-se, em estado latente para ser estudado, investigado, interpretado, discutido e explicado, tamanha gama de possibilidades cujo ponto de partida reside nas tais, coisas desta terra. Quaisquer que tenham sido os interesses do autor paulista, seu legado composto pelas mais variadas tipologias, quais sejam arquivística, biblioteconômica e museológica, é fonte inesgotável de aprofundamento da pesquisa investigativa. Acrescente-se o mistério da correspondência a ser aberto após 50 anos de sua morte, o que amplia e por vezes até pode eventualmente carrear ações fetichista.

Neste sentido, o trabalho cotidiano que venho realizando com a coleção de artes plásticas pertencente a Mário de Andrade, há aproximadamente uma década, desencadeou reflexões e relações relativas à problematização da sua constituição nos diferentes tempos e 
espaços. Para além do contato direto com a Coleção de Artes Visuais do Instituto de Estudos Brasileiros, local em que esta série artística se encontra hoje, existe ainda a relação com todo o patrimônio herdado, seja o fundo pessoal e a coleção de livros do próprio Mário de Andrade, seja o cabedal intelectual gerado a partir das pesquisas com todo este conjunto, nos mais diferentes campos do conhecimento.

O recorte deste estudo se volta, portanto, para a coleção de obras de arte, por meio da intertextualidade entre as partes deste vasto universo documental. O próprio poeta dá pistas sobre a validade deste procedimento, quando mescla as suas mais variadas lembranças, com as quais se cerca, para nunca estar sozinho.

Compõe-se o acervo de inúmeros suportes com amplas referências e que se encontram firmadas no poema Nunca estará sozinho, em que fornece pistas sobre os símbolos e valores defendidos. Entre estas, alude a certa estação então cinquentenária, talvez Estação da Luz, que abre caminhos ferroviários para o interior; pergunto: seria do estado paulista, ou do Brasil, ou ainda o seu próprio? Por que Clóvis Graciano o acompanharia, juntamente com "o vigor exuberante" de sua pintura? Rememoraria o início do pintor que pintava tabuletas para a estrada férrea?

As recordações emblemáticas de sua vida, memoradas a partir da "festa da cor" de Anita Malfatti, pela qual conheceu a arte moderna, soluções que modificaram sua conceituação estética? Ou, a figura simbólica de Vilanova Artigas, associada com o grupo da Família Artística Paulista, com quem dividia aulas de modelo-vivo e que zelava pela operosidade do movimento modernista? Ou ainda, saudava a renovação na arquitetura, que culminou, tempos depois, na reformulação educacional da Faculdade de Arquitetura e Urbanismo (FAU USP)?

As contradições da vida, que levam Yan, provavelmente de Almeida Prado, ligado à aristocracia paulista, a lhe pedir esmola, quando o natural seria o contrário? Teria Ihe pedido um texto? Os ressentimentos de inimigo, que o conduzem para o exílio voluntário, no Rio de Janeiro? Estaria se referindo ao Prefeito Interventor Francisco Prestes Maia? A relação com seu secretário particular e bibliotecário José Bento Faria Ferraz, que o acompanha confidentemente, ora lado a lado em sua casa, ora distante nos tempos da então capital federal, a servir como ponte entre ele e suas coisas?

O poema passaria também pelo interesse voltado para o folclore, quando envia ao Nordeste grupo para pesquisar as mais variadas manifestações culturais, durante sua gestão, como Diretor, no Departamento de Cultura. Acrescentem-se também as viagens pelo Brasil, os tempos felizes em que fora o "turista aprendiz", a desbravar os recantos mais recônditos do Amazonas, sempre a partir de São Paulo, local em que tudo começara.

Este poema nos dá pistas sobre a conexão das partes no todo, como a fazer referências constantes em sua vida, sua obra, suas memórias e também sua coleção, cujo pouso final deste sonho é o Instituto de Estudos Brasileiros. Esta instituição concebida num esforço simbiótico entre diversos intelectuais ligados à Universidade de São Paulo, representado aqui na figura do Professor Sérgio Buarque de Holanda, com objetivo de unir a pesquisa científica em torno de fontes distintas, a fim de elucidar os diversos e múltiplos aspectos da cultura brasileira, para muito além da retórica do texto.

Ao trazer o poema de Mário de Andrade, é possível perceber que o colecionador se utiliza de sua multiplicidade de interesses para construir a sua própria imagem e, por 
analogia, a coleção. Assim, o objetivo desta pesquisa é o estudo das obras de artes plásticas pertencentes a Mário de Andrade pelo viés das escolhas do colecionador ao expô-la no ambiente doméstico, como a fazer uma curadoria da arte do século $\mathrm{XX}$, principalmente a brasileira, com resultados de atribuição ou não de valores que até hoje se fazem sentir em instituições, mostras, manuais e livros sobre Arte Brasileira.

A metodologia se vale da investigação filológica, em fontes textuais e imagéticas, tanto primárias quanto secundárias, a fim de reconhecer o acervo significativo para análise da coleção de artes plásticas. Procura-se qualificar o conjunto, relacionando-o e interpretandoo, como um trabalho institucional de discussão das escolhas de Mário de Andrade além das habituais escolhas de caráter meramente colecionista, ou patrimonialista, ou seja, centrada em fatores biográficos e/ou aleatórios, estaria valorando determinados eixos, ainda pouco reconhecidos como a sua seleção para a exposição ao olhar.

O levantamento da disposição da coleção em sua residência foi realizado a partir de dois filmes, cujos títulos são iguais Casa de Mário de Andrade, realizados em 1955 e 1968, associados a fotografias publicadas em periódicos, após a morte do colecionador. É interessante notar que as imagens da casa, ainda com a presença de Mário de Andrade, pouco documentam a distribuição das obras pelos ambientes, possivelmente por focar a imagem do intelectual, em detrimento de sua relação coma coleção, uma postura mais guiada pela palavra e a produção.

É importante ressaltar a riqueza encontrada na leitura de cartas enviadas por Mário de Andrade, ainda manuscritas ou já publicadas. Maior fortuna, quando além do que fora missivista, correspondências recebidas foram incorporadas, a formar uma rede enorme de remetentes e destinatários verdadeiro mosaico de uma época.

Somam-se a essas fontes, os textos literários de Mário de Andrade, sejam crônicas, romances ou poesias que também fazem parte da documentação consultada, sempre com o objetivo de esclarecer elementos que elucidassem as questões relativas aos caminhos de sua coleção e, também, da exposição ao olhar em sua residência.

O processo de reconstituir a residência da Rua Lopes Chaves conjugou três elementos principais: espacialização da casa e a inserção na malha urbana, realizada a partir do levantamento arquitetônico, elaboração de planta baixa e execução de maquete eletrônica; juntamente com os filmes, um de Ruy Santos datado de 1955 e outro de Geraldo Sarno e Thomaz Farkas, 1968. Foi fundamental para o enriquecimento destes materiais, a entrevista concedida por Antonio Candido, realizada em 27 de outubro de 2011, que, com toda a simpatia e generosidade, elucidou os usos da casa, ou seja, a maneira como os moradores a utilizavam. É também do Prof. Antonio Candido, juntamente, com da Prof.a. Gilda de Mello e Souza, o depoimento escrito que se referia à moradia da Lopes Chaves. Além disso, como contraponto de comparação, foram acionadas reportagens realizadas após a morte do escritor foram acionadas, cujo interesse se voltava, também, para sua casa.

A pesquisa não poderia deixar de ter como material básico o conjunto de Artes Plásticas da Coleção Mário de Andrade, que foi todo fotografado, em formato digital, para que os registros imagéticos das obras, quando acionadas, compusessem o corpus de análise. Para completar, as leituras de obras, livros ou revistas, de autores que falam sobre o tema, foram fundamentais para construir a apreciação de cunho teórico. 
A este arcabouço investigatório, se junta à análise do processo de aquisição do Acervo Mário de Andrade pela Universidade de São Paulo, indo aos instrumentos jurídicos e contratuais, cujo trâmite revela os caminhos, e até desvios, de sua chegada ao IEB.

O principal trabalho dedicado à série artes plásticas da coleção de Mário de Andrade é catálogo publicado por Marta Rossetti Batista e Yone Soares de Lima, que fora fruto de extensa pesquisa de identificação de cada uma das obras, juntamente com a sua inserção insere na história da arte brasileira. Esta investigação, de praticamente quatro décadas, teve ainda como frutos exposições institucionais, originadas de resultados parciais desta análise.

Para isso, esta dissertação está estruturada em três capítulos que funcionam como afunilamento do olhar frente à coleção de Mário de Andrade. A primeira escala, mais ampla, dá conta das expectativas do colecionador, que possuía o desejo de deixá-la para a posteridade, em instituições de cunho público, que veio ao encontro do objetivo institucional relativo ao Acervo do IEB. Já uma escala intermediária é o entendimento dessa coleção como detentora dos valores modernistas, levada ao olhar na casa da rua Lopes Chaves; e, por fim, a escala mais detalhada guarda em sua disposição amarras com os modelos de decoração do século XIX, como sala de visitas e de jantar, ou em seu estúdio ligado ao mundo externo.

O primeiro capítulo Pouso final dos sonhos trata do uso público que, desde sua formação Mário de Andrade mantinha como parâmetro de intrínseco para compreender o seu colecionismo. Os seus desejos e intenções expressavam que cada parte, do vasto conjunto reunido, iria para instituições paulistas conectadas, de alguma forma ao intelectual. Seu destino, entretanto, levaria as coisas da terra a permanecerem juntas no regaço duma casa de cultura.

Se por um lado, a coleção encontrara pouso, por outro contribui para a conformação dos seus rumos institucionais. Assim, a incorporação do Fundo Mário de Andrade vem fornecendo elementos para o fomento da reflexão e pesquisa sobre os múltiplos aspectos da cultura brasileira, bem como possibilitou e delineou os moldes de organização das suas partes conforme o tipo documental, o que deu origem aos locais de preservação: Arquivo, Biblioteca e Coleção de Artes Visuais, correspondentes, respectivamente, aos materiais arquivísticos, biblioteconômicos e museológicos.

Os objetos deixam de lado seu utilitarismo para assumir apenas sua carga simbólica, ou seja, nessa operação eles transformam-se em semióforos, termo que define as peças destinadas à promoção, celebração e consolidação, neste caso do movimento modernista, das modificações urbanas para atingir a tal cidade sonhada, neste caso São Paulo e, também, de seu colecionador.

Não se deve esquecer que, no momento em que a coleção era formada, a capital paulista contava com poucas instituições culturais públicas, entre elas a Pinacoteca do Estado e o Museu Paulista, além dos Museus de Arte Moderna e o Museu de Arte de São Paulo, ligados a grupos de industriais, em geral já consolidados, durante a primeira metade do século XX. Assim, a coleção de Mário de Andrade, para além da celebração do moderno, traz consigo um caráter de pesquisa interpretativa, formação educacional para diferentes faixas etárias e extensão para a sociabilidade do saber, com a respectiva volta para insuflar renovação para o IEB USP, tripé indissociável da universidade pública. 
A sua própria transformação de poeta simbolista para modernista ocorre em concomitância com o nascimento do colecionador de arte, ou seja, no nascedouro já visava pensar e comunicar, sem dicotomia. Para adquirir uma obra, é preciso que, num primeiro impulso, ela o comova. Os primeiros itens estão ligados com sua atualização às vanguardas estrangeiras, principalmente as francesas e alemãs, e também com a identificação das transformações brasileiras, seja por artistas daqui estudados no exterior, seja por estrangeiros que aqui atuassem.

Essa tendência continua, ao seguir os passos das diversas fases do movimento modernista, identificados no balanço que o próprio colecionador fizera deste período: heróico, da orgia intelectual e de construção. Interligadas pela pesquisa estética, atualização artística e consciência nacional, que segundo Mário de Andrade as três seriam as feições fundamentais para transformação da realidade brasileira. Dessa maneira, a coleção revela o intuito de construir a própria história artística do modernismo, num momento de primazia do academicismo.

O capítulo inicial encerra-se com as questões relativas ao reconhecimento da coleção de Mário de Andrade ainda em sua época, com ênfase à preservação e à manutenção deste universo da cultura material.

Já o segundo capítulo, Casas e lugares que falam de Mário, trata da ambientação das coisas da terra. Para isso recorreu-se a relação de Mário de Andrade com a capital paulista, levando-se em conta a espacialização das diversas casas que habitara, recorrentes em seus poemas, dos salões que frequentara, enfim da cidade em que vivera, que fora registrada em sua coleção.

Assim, recuperaram-se na Paulicéia três casas de Mário de Andrade: da Rua Aurora, do Largo Paissandu e da Rua Lopes Chaves. A primeira pertence ao imaginário do poeta, afinal o colecionador residira ali até os seis anos. O Largo Paissandu marcara presença tanto no prelúdio da coleção, quanto na adesão e na atuação do movimento moderno.

Desde 1921, Mário mudara-se para a Barra Funda e fizera parte, juntamente com outros salões - de Dona Olívia Guedes Penteado e da pintora Tarsila do Amaral -, da introdução da nova visualidade estética. A casa da Lopes Chaves continuara como palco de sua vida até sua morte em 1945, perfazendo todas as fase do movimento modernista.

Contudo, em São Paulo, Mário de Andrade nunca morou sozinho, portanto a disposição das obras ao olhar modelou-se com os usos e costumes da própria família, seja nos espaços privados, seja nos de uso público. Nesse sentido, foi fundamental a reconstituição da casa, alcançada também por meio da articulação de registros filmográficos e fotográficos, associado a reportagens e depoimentos, que culminou com a execução de maquete eletrônica, que permitiu locar a coleção de artes plásticas durante o período entre a morte do colecionador e a vinda das coisas da terra ao IEB.

Por fim, o terceiro capítulo Mário entre as suas e as coisas da terra, foca-se no andar superior nas áreas de uso exclusivo do colecionador, que se dirigia à construção da sua imagem pública.

Os distintos cômodos da casa, que serviam para a exposição ao olhar, possuem estreita relação com todos os moradores da casa. A sala de visitas e de jantar, nas quais o arranjo das obras revela uma rigorosa obediência aos preceitos pré-estabelecidos, mesmo que as obras fossem de alguma forma inovadoras. Além disso, misturavam-se com 
elementos visuais externos à coleção, tal como imagens católicas e retratos de família, o que diluía a força das obras caso observadas em outro contexto. Ainda no térreo, a saleta de piano é o ambiente que mais se aproxima da intenção de expor obras que perpassem o movimento modernista.

O intervalo entre espaços, seja da entrada da casa, seja do primeiro para a segundo andar, são locais de transição, não só da residência, como também das modificações estéticas proporcionadas pelo movimento modernista e a vida do poeta.

O andar superior é a produção do espaço por Mário de Andrade, local em que tudo funciona a dar a construção da imagem de seu colecionador, seja as obras expostas ao olhar, sejam as impressões deixadas em quem visitasse. Além disso, o capítulo apresentará as fruições da coleção, justamente aquela que carrega consigo quando vai para o Rio de Janeiro. 
1. POUSO FINAL DOS SONHOS 


\section{Quando eu morrer}

Quando eu morrer quero ficar, Não contem aos meus inimigos,

Sepultado em minha cidade,

Saudade.

Meus pés enterrem na rua Aurora,

No Paissandu deixem meu sexo,

$\mathrm{Na}$ Lopes Chaves a cabeça

Esqueçam.

No Pátio do Colégio afundem

O meu coração paulistano:

Um coração vivo e um defunto

Bem juntos.

Escondam no Correio o ouvido Direito, o esquerdo nos Telégrafos,

Quero saber da vida alheia,

Sereia.

O nariz guardem nos rosais, A língua no alto do Ipiranga

Para cantar a liberdade.

Saudade...

Os olhos lá no Jaraguá Assistirão ao que há de vir, O joelho na Universidade, Saudade...

As mãos atirem por aí, Que desvivam como viveram,

As tripas atirem pro Diabo, Que o espírito será de Deus.

Adeus.

Lira Paulistana, 1945

Mário de Andrade 


\section{No regaço duma casa de cultura}

O fundo pessoal e as coleções ${ }^{1}$ que Mário de Andrade formou, todo esse legado, ou pelo menos boa parte dele, faz parte do Acervo do Instituto de Estudos Brasileiros da USP desde 1968, quando foi adquirido e incorporado à Universidade de São Paulo. Esta grande e diversificada coisas desta terra ${ }^{2}$, como ele mesmo definiu em sua carta testamento, se compõem de: obras inéditas; fichário analítico; correspondência; gravuras; monotipias; aquarelas; guaches; desenhos; quadros; esculturas de arte; coleção de santos; objetos de valor etnográfico ou folclórico; jornais e documentos do chamado Movimento Constitucionalista de 1932; fotografias; partituras; discos de valor para estudo, folclóricos, nacionais e estrangeiros; livros com dedicatória; obras ditas "de luxo" com ilustrações e encadernação distinta; livros raros antigos; livros de musicologia e artes; além de dicionários, livros fundamentais clássicos fundamentais das literaturas, de estudo de ciências, de artes plásticas, de música ${ }^{3}$. Somam-se ainda a esse elenco, duas máquinas de escrever Remington, uma de mesa e outra portátil, bem como seu harmônio e algumas peças de seu mobiliário.

Quando Mário de Andrade expressou seus desejos e intenções, já estava posto que a destinação devesse ser pública. Durante os 23 anos entre sua morte e a chegada ao IEB, este acervo permaneceu na residência em que Mário de Andrade morava com sua mãe, Mariquinha, Maria Luísa de Almeida Leite Moraes de Andrade, e a madrinha, irmã de sua mãe, Nhanhã, Ana Francisca de Almeida Leite Moraes.

Possivelmente nem mesmo o próprio intelectual teria cogitado da possibilidade de todo esse conjunto permanecer em uma única instituição, entre as que ele atuou ou manteve proximidade, dada a precariedade destas naquele momento e não apenas na Paulicéia. Em 1944, sua carta-testamento para o irmão Carlos de Moraes Andrade, dirigia cada tipologia documental a um determinado caminho: correspondências lacradas por 50 anos à Academia Paulista de Letras; livros em geral, com dedicatória, de luxo e obras de arte em suporte de papel à Biblioteca Municipal; duplicatas de livros à Biblioteca de Araraquara ou, no caso de Brasiliana, à Biblioteca da Faculdade de Filosofia Ciências e Letras, da Universidade de São Paulo; quadros e esculturas à Pinacoteca do Estado; objetos relativos ao Movimento Constitucionalista de 1932 para o Instituto Histórico de São Paulo; a coleção de santos e documentos religiosos ao Museu da Cúria Metropolitana de São Paulo; objetos de valor etnográfico ou folclórico, bem como discos de estudo à Discoteca Pública do Departamento de Cultura.

\footnotetext{
${ }^{1}$ Segundo o Conselho Internacional de Arquivo, a definição de "fundo pessoal é o conjunto de documentos organicamente produzido e/ou acumulado por um indivíduo no decurso das suas atividades e funções, enquanto coleção seria a reunião documental acumulada com base em alguma característica comum, sem atentar para a sua proveniência". CONSELHO Internacional de Arquivos. ISAD(G): Norma geral internacional de descrição arquivística: 2a ed., adotada pelo Comitê de Normas de Descrição, Estocolmo, Suécia, 19-22 de setembro de 1999, versão final aprovada pelo CIA. Rio de Janeiro: Arquivo Nacional, 2001, p.5.

${ }^{2}$ Quando as palavras estiverem em itálico com corpo menor, são termos do próprio Mário de Andrade.

${ }^{3}$ Carta testamento escrita por Mário de Andrade em 22 mar. 1944 a seu irmão, Carlos de Moraes Andrade. In: ALVARENGA, Oneyda. Mário de Andrade, um pouco. Rio de Janeiro/São Paulo: J. Olympio/Conselho Estadual de Cultura, 1974, p. 31-35.
} 
O poeta detalhou com requintes a diversidade constitutiva de sua produção: no que concerne às suas obras literárias, sugeria duas possibilidades: integrar a publicação das Obras Completas; ou, no caso de pesquisas em andamento, sem finalização, apenas ser passível de consulta pública, de preferência em alguma biblioteca municipal. Em relação às suas sistemáticas de estudo, tal como o fichário analítico, deixaria para amigos próximos como Luís Saia e Oneyda Alvarenga, de acordo com seus interesses. Por fim, houve ainda, por parte do autor, a preocupação em transmitir para os sobrinhos, filhos de sua irmã, Maria de Lourdes de Andrade Camargo, os direitos autorais, a herança que recebera do pai, e as jóias de valor, além de livros e discos que não fossem de interesse da Discoteca Municipal.

As escolhas para destinação de seu amplo e vasto conjunto documental revelam a ligação de cada uma delas com o próprio poeta. Desde 1939, Mário de Andrade era membro da Academia Paulista de Letras, organização de escritores, e ocupava a cadeira de número 3, cujo patrono é Matias Aires, fundada por Luís Pereira Barreto, com sucessão de Alfredo Pujol e, depois, Franco da Rocha ${ }^{4}$.

Apenas o Instituto Histórico não possui laços tão estreitos quanto as demais organizações, pois está vinculado à história brasileira. Contudo, cumpre lembrar que o poeta preservaria elementos relacionados aos acontecimentos paulistas, ocorridos durante o Movimento Constitucionalista de 1932, o que denota um viso muito peculiar, irônico e afetivo com o tema. O então denominado Museu da Cúria aproxima-se ao autor pela sua religiosidade, inúmera vez reiterada em carta e documento ${ }^{5}$. Dentre as cidades do interior paulista, Araraquara the era cara devido a familiares que ali moravam. Inclusive, é, em 1926, na ocasião das férias de verão, hospedado na chácara de Tio Pio ${ }^{6}$, que Mário de Andrade escreveu uma "versão expurgada" de Macunaíma ${ }^{7}$.

Já, a Pinacoteca de São Paulo, criada em 1905, era das poucas instituições museológicas existentes na capital paulista, naquele momento, ligada a uma escola privada e sem maior expressão, ainda que Tarsila do Amaral tivesse breve passagem por lá. De abril de 1931 ao início de 1932, Mário de Andrade participara do Conselho de Orientação Artística $^{8}$, no qual uma das atribuições era justamente a aquisição de obras de arte para o Estado. A destinação de suas obras para a Pinacoteca corrobora, por um lado, com a destinação pública de sua coleção e, por outro, na entrada do moderno em instituição

${ }^{4}$ PIO \& MÁRIO: diálogo da vida inteira. A correspondência entre o fazendeiro Pio Lourenço Corrêa e Mário de Andrade. Antonio Candido (traços biográficos); Gilda de Mello e Souza (introdução); Denise Guaranha (texto e notas); Tatiana Longo Figueiredo (texto, datas e revisão ortog.). Rio de Janeiro/São Paulo: Ouro sobre Azul/ SESC-SP, 2009, p. 301.

5 “Mário de Andrade era católico, membro da Congregação da Imaculada Conceição, da Igreja de Santa Ifigênia, e irmão da Ordem Terceira do Carmo, provavelmente por influência familiar". In: BATISTA, Marta Rossetti. O crítico e o colecionador. Memória. Ano V. $\mathrm{n}{ }^{0} 17$. São Paulo: Departamento de Patrimônio Histórica da Eletropaulo, jan./fev./mar. de 1993, p. 71 a 76.

${ }^{6}$ Pio Lourenço Corrêa (1875-1957) foi grande amigo do pai de Mário de Andrade era fazendeiro proprietário da Chácara da Sapucaia, em Araraquara, na qual Mário buscava refúgio. Sua mulher Zulmira de Moraes Rocha vinha a ser prima de Mário de Andrade. "Chamavam-no de tio por ouvi-lo chamar assim um primo com o qual conviviam intimamente e era, este sim, sobrinho de Tio Pio". In: PIO \& MÁRIO: diálogo da vida inteira. A correspondência entre o fazendeiro Pio Lourenço Corrêa e Mário de Andrade, op. cit, p. 9-13.

7 SOUZA, Gilda de Mello e \& CANDIDO, Antonio. A lembrança que guardo de Mário. Revista do Instituto de Estudos Brasileiros, São Paulo, 36: 9-25, 1994, p. 10.

${ }^{8}$ Decreto no. 4.965, de 11 de abril de 1931. 
tradicionalmente acadêmica ainda que algumas obras modernas já houvessem então ingressado ${ }^{9}$.

No prelúdio da implantação do Departamento de Cultura, Mário de Andrade fora a Campos dos Goitacazes, no estado fluminense ${ }^{10}$, para analisar a brasiliana ${ }^{11}$ de Alberto Frederico de Morais Lamego. Esta coleção ia ao encontro tanto da ampliação dos volumes quanto da formação do perfil de pesquisa, eixos de ação pensados para a Biblioteca Municipal de São Paulo, pelo escritor paulista ${ }^{12}$; contudo, seguiu para a Faculdade de Filosofia, Ciências e Letras da recém-fundada Universidade de São Paulo ${ }^{13}$.

É interessante notar que, ao lado da Brasiliana composta por documentos relativos à história, geografia, etnologia e literatura, existem ainda obras de arte de Alberto Lamego que, no entanto, não integraram a compra realizada pelo governo de São Paulo, em $1935^{14}$. Em crônica publicada no Estado de S. Paulo ${ }^{15}$, Mário não chega a comentar a coleção de quadros, todavia recebe correspondência de Lamego, na qual manifestava o desejo de trazêla para São Paulo, "único estado brasileiro que leva essas coisas a sério" ${ }^{16}$. Seriam obras "representativas das escolas flamenga, holandesa, italiana e portuguesa" que adquiridas em 1949 pelo governo do Estado do Rio de Janeiro, seguiram para o Museu Antônio Parreiras de Niterói ${ }^{17}$.

Ainda mais notória é a data de transferência da coleção Lamego para o IEB: 1968. Mesmo ano em que o acervo de Mário de Andrade é incorporado ao Instituto. Conforme os dizeres do próprio autor de Macunaíma, a destinação da brasiliana de Lamego para a Universidade e, por paralelismo, a sua própria seriam uma "espécie de apoteose", "destino

9 Já estavam incorporadas as seguintes obras modernas: Tropical de Anita Malfatti, São Paulo da Tarsila, $O$ Bananal do Segall, a Carregadora de Perfume do Brecheret e, principalmente, O Mestiço de Portinari. Para saber mais, consultar: ARAUJO, Marcelo Mattos. Os modernistas na Pinacoteca do Estado: o museu entre a vanguarda e a tradição. São Paulo: FAU USP, 2002. (tese de doutorado)

${ }^{10}$ Quando Mário segue para essa viagem é com carta de apresentação de o então diretor do Museu Paulista, Affonso D'Escragnolle Taunay, conforme correspondência trocada entre os dois. São Paulo, 17 out. 1935, pertencente ao Fundo Mário de Andrade, código de referência: MA-C-CPL6638.

11 “Uma brasiliana é o conjunto de reflexões da mais variadas origens e sobre os mais variados aspectos do Brasil agrupadas sob a forma de produções intelectuais", segundo CALDEIRA, João Ricardo. IEB: origem e significados - uma análise do Instituto de Estudos Brasileiros da Universidade de São Paulo. São Paulo: Oficina do livro Rubens Borba de Moraes / Imprensa Oficial, 2002, p. 160.

12 RAFFAINI, Patrícia Tavares. Esculpindo a cultura na forma Brasil: o Departamento de Cultura de São Paulo (1935-1938). São Paulo: Humanitas / FFLCH USP, 2001, p. 67.

${ }^{13}$ DUARTE, Paulo. Departamento de Cultura: vida e morte de Mário de Andrade. Revista do Arquivo Municipal. São Paulo: DPH v. 198, 1990, p. 80.

${ }^{14}$ MARX, Murilo. Apresentação. NOGUEIRA, Arlinda Rocha; BELLOTO, Heloísa Liberalli; HUTTER, Lucy Maffei; CARDOSO, Maria Cecília de Castro. Coleção Alberto Lamego: catálogo dos manuscritos. 2a ed. São Paulo: IEB USP, 2002, p. 9.

${ }^{15}$ ANDRADE, Mário de. A Biblioteca Lamego, reproduzida na íntegra na apresentação da Prof.a. Myriam Ellis para a primeira edição do catálogo de manuscrito. NOGUEIRA, Arlinda Rocha; BELLOTO, Heloísa Liberalli; HUTTER, Lucy Maffei; CARDOSO, Maria Cecília de Castro, op.cit., pp. 16-18.

16 Correspondência de Alberto Lamego a Mário de Andrade. Campos dos Goitacazes, 20 maio 1936, pertencente ao Fundo Mário de Andrade, código de referência: MA-C-CPL3885.

17 Museu Antônio Parreiras. Disponível em: <http://www.museusdoestado.rj.gov.br/map/colecoes4.htm>. Acesso em: 24 jan. 2012. 
mais humano e generoso que podia ter, no regaço duma casa de cultura. Já agora ela será sem dúvida o melhor fim para obras vultosas" ${ }^{18}$.

Assim Mário de Andrade aponta para um dos tripés da Universidade, a cultura e extensão universitária. Sua própria Brasiliana representaria a abertura encontrada para inserção do poeta nesta instituição, que vira ser criada e da qual nunca participara. Dentre as instituições de destino citadas em seu testamento, o fomentador cultural se envolveu diretamente em duas delas, quais sejam: criação da Discoteca Pública e ampliação da Biblioteca Municipal.

Durante a permanência de Mário de Andrade no Departamento de Cultura, de 1935 a 1938, o projeto para a Biblioteca Municipal visava tanto à ampliação do número de livros, com perfil de formar "uma coleção brasiliana para pesquisas específicas acerca da história do país" ${ }^{19}$, quanto à construção de um novo edifício. Na direção da compra de novos acervos, a Biblioteca recebeu a coleção de Felix Pacheco. E, ainda, na gestão de Fábio Prado ficou acertado o terreno e a contratação da execução da sua nova sede, projeto do arquiteto Jacques Pilon ${ }^{20}$. Hoje é a Biblioteca Mário de Andrade, localizada à Rua da Consolação.

A criação da Discoteca Pública Municipal inseria-se no fornecimento de fontes sonoras para as transmissões da Rádio-Escola, com objetivo de transmitir "notícias, informações de interesse público, óperas, concertos, palestras e discursos e conferências" ${ }^{21}$. Sem a implantação da Rádio, a Discoteca limitou-se a divulgar esse material em cabines, assim como em uma biblioteca lê-se livro. Mesmo assim, Mário de Andrade reconhecia o trabalho e o potencial desta instituição ao destinar-lhe objetos etnográficos, folclóricos, bem como seus discos de estudo.

Nas diretrizes deixadas para o irmão, é curioso que um professor de música e musicólogo, dedicado tanto ao estudo musical quanto às aulas particulares e ao ensino no Conservatório Dramático e Musical de São Paulo, não tenha por expresso sua vontade relativa à destinação de suas partituras, apenas de seus discos e livros deste universo. Fica a questão. Devido à importância do acervo, o Serviço do Patrimônio Histórico e Artístico Nacional manifestara intenção de manter o conjunto indiviso de tudo que pertencera a Mário de Andrade. Nesse sentido, Luís Saia e Oneyda Alvarenga foram figuras importantes na movimentação deste processo ${ }^{22}$.

\footnotetext{
${ }^{18}$ ANDRADE, Mário de. A Biblioteca Lamego. In: NOGUEIRA, Arlinda Rocha; BELLOTO, Heloísa Liberalli; HUTTER, Lucy Maffei; CARDOSO, Maria Cecília de Castro, op. cit., p. 16.

${ }^{19}$ RAFFAINI, Patrícia Tavares. op. cit., p.67.

${ }^{20}$ No artigo-depoimento de Rubens Borba, o prefeito que sucedeu Fabio Prado, o engenheiro Prestes Maia tentou inviabilizar a obra, contudo o contrato com a construtora previa multa rescisória caso o empreendimento fosse interrompido. Assim, foi assegurado o prosseguimento da construção. Prestes Maia, no entanto, alterou o projeto de tal forma a impedir a colocação dos alicerces das torres previstas no projeto, o que reduziria drasticamente o espaço para os livros; além de alterar o projeto de iluminação. MORAES, Rubens Borba de. O engenheiro, o bibliotecário e o sentido de um projeto cultural. Revista da Biblioteca Mário de Andrade. São Paulo 50: 54-59, 1992, pp. 56-57.

${ }^{21}$ RAFFAINI, Patrícia Tavares. op. cit., p. 76.

${ }^{22}$ ALVARENGA, Oneyda. op. cit., pp. 29 e 38.
} 
A idéia manifesta do grupo - Oneyda Alvarenga, Luís Saia e, também, Antonio Candido - era transformar a residência da Rua Lopes Chaves na Casa Mário de Andrade ${ }^{23}$. Contudo, a moradia continuava habitada por D. Mariquinha e D. Nhanhã ${ }^{24}$. Talvez faltasse interesse naquele momento para dar continuidade ao assunto, uma vez que a morada do escritor, na atualidade, faz parte do conjunto de Instituições Culturais, a cargo da pasta da Secretaria de Cultura do Estado de São Paulo. Durante as décadas de 1970 e 80, lá funcionou o Museu de Literatura Casa Mário de Andrade; e, a partir de 1990, é ocupada pela Oficina da Palavra Casa Mário de Andrade. Entretanto, a casa nunca foi efetivamente desapropriada ${ }^{25}$.

Se por um lado, a iniciativa de manter o conjunto documental do intelectual foi bemsucedida; por outro, o espaço em que tudo havia sido formado, bem como sua ambiência, ficaram cessados no tempo. Foi preciso duas décadas se passarem para que as coisas desta terra, pertencentes a Mário de Andrade, encontrassem destino certo. Mais uma vez, é a mão do Professor Antonio Candido de Mello Souza ${ }^{26}$ que direciona este patrimônio ao Instituto de Estudos Brasileiros, ao intermediar as tratativas entre a Universidade e os familiares, representados por Carlos de Moraes Andrade, irmão de Mário.

Em carta, de 3 outubro de 1966, destinada ao então diretor, Prof. José Aderaldo Castello $^{27}$, o notável Professor sugere que para garantir a exequibilidade da proposta, a família seja recompensada, em virtude de sua boa vontade. Em contrapartida, o IEB incorporaria o patrimônio na íntegra, de modo a garantir que "tudo fique o menos dividido e o menos espalhado possível e, ao mesmo tempo, em condições de prestar o Máximo serviço à coletividade" ${ }^{28}$, conforme desejo do próprio Mário de Andrade.

Para efetivação da vinda deste acervo, durante 1967, foram realizados levantamento e avaliação de modo a se estipular seu valor. Para isso, o então reitor, Prof. Luiz Antônio da Gama e Silva $^{29}$, constituiu comissão de avaliação ${ }^{30}$ composta pelo diretor do IEB, juntamente com Prof. Walter Zanini ${ }^{31}$ e Sr. Américo de Souza Pinto ${ }^{32}$.

${ }^{23}$ A primeira casa-museu do estado se daria apenas em 1946, com a fundação ligada a outro escritor, ou seja, da Casa de Cultura Euclides da Cunha, na cidade de São José do Rio Pardo. Disponível em < http://casaeuclidiana.org.br>. Acesso em 25 jan. 2012.

${ }^{24}$ Ibidem, p. 28.

25 Depoimento de Antonio Candido, a A. em 27 out. 2011.

${ }^{26}$ O Prof. Antonio Candido realizou entre 1963 e 1968, projeto pioneiro de exploração da biblioteca de Mário de Andrade, ainda na casa do escritor. In: ESCOREL, Lilian. Escritura à margem: a criação poética de Mário de Andrade nas páginas da revista L'Esprit Nouveau . Disponível em < http://www.ieb.usp.br/ marioscriptor/escritos/ escritura-a-margem-a-criacao-poetica-de-mario-de-andrade-nas-paginas-da-revistalesprit-nouveau.html>. Acesso em 15 fev. 2012.

${ }^{27}$ Ocupou a direção do IEB, de 1966 a 1981. Segundo Antonio Candido, após sua criação em 1962 pelo Prof. Sérgio Buarque de Holanda, esta direção operacionalizou a Instituição para que assumisse a feição próxima ao que é hoje. Depoimento de Antonio Candido, a A. em 27 out. 2011.

${ }^{28}$ Processo USP 1967.1.107.31.8, p. 10.

${ }^{29}$ Logo em seguida, viria a se tornar Ministro da Justiça do governo de Artur da Costa e Silva (de 15 de março de 1967 a 31 de agosto de 1969). Em 1968, seria redator e locutor do Ato Institucional no 5, baixado em 13 de dezembro.

${ }^{30}$ Processo USP 1967.1.107.31.8, p. 58.

${ }^{31}$ Primeiro diretor do Museu de Arte Contemporânea da USP, de 1963 a 1978.

32 Dono da Livraria Américo de Souza Pinto - livros usados (esgotados e raros). Processo USP 1967.1.107.31.8, p. 114. 
Neste levantamento, o Sr. Souza Pinto ficou a cargo do volume estimado de livros, o qual the atribuiu o valor de NCr\$85.000,00. Já a estimativa das obras de arte, imaginária religiosa e popular, juntamente com os objetos relacionados à Revolução de 1932 ficou sob responsabilidade do Prof. Zanini, com consultoria do Sr. Pedro de Oliveira Ribeiro Neto em relação a arte religiosa, e inventário pela então licenciada, hoje Prof.a. Telê Porto Ancona Lopez. Este levantamento se fez pela valoração obra a obra e chegou a seguinte cifra $\mathrm{NCr}$ \$ 426.832,00. Assim, a quantia final totalizou $\mathrm{NCr} \$ 511.832,00^{33}$ (quinhentos e onze mil oitocentos e trinta e dois cruzeiros novos), dos quais a maior parte destinava-se à coleção de artes visuais $^{34}$.

Em 1968, enfim o patrimônio de Mário de Andrade chega ao IEB. Não é pequena a importância desta vinda ao IEB, uma vez que é a partir de sua chegada que a instituição se delineia com os contornos em que se encontra hoje. A grande quantidade e a variedade documental foram trabalhadas institucionalmente de acordo com a arquivística, a biblioteconomia e a museologia, o que deu forma ao tripé do acervo: Arquivo, Biblioteca e Coleção de Artes Visuais, tudo para disponibilização ao público, e, em especial, à pesquisa ${ }^{35}$.

O processo de configuração do Acervo do Instituto, tal qual hoje se encontra, não se deu imediatamente, nem tampouco se pode atribuir o crédito exclusivo ao patrimônio de Mário de Andrade, porém é inegável a catálise por ele proporcionada. Este preâmbulo permite observar o caminho percorrido entre o desejo da destinação pública pelo intelectual e sua efetiva disponibilidade à coletividade, como forma de conhecimento de ampla gama da cultura de uma época, a fim situar o leitor no que universo de que se fala neste trabalho.

\section{Desejos e intenções às coisas desta terra}

Os múltiplos interesses de Mário de Andrade se compatibilizam com o que ajuntara durante a vida. Consciente da importância do material reunido e, ao que tudo indica, interessado que houvesse a sociabilidade com o acesso da coletividade, o colecionador, assim como fez no poema Quando eu morrer, estabeleceu os locais para cada uma de suas partes.

Dentre as divisões propostas, é significativa aquela referente às obras de arte em suporte de papel, tais como gravuras, monotipias, aquarelas, guaches, desenhos; e, os óleos e as esculturas. Uma seguiria para a Biblioteca Municipal e a outra para a Pinacoteca do Estado. Para dar luz a essa separação, indicada pelo modernista, é fundamental o ensaio Do Desenho, realizado por Mário de Andrade. Uma primeira versão deste texto publicada em $O$ Estado de S. Paulo, em $1939^{36}$, e adicionada à reunião de textos seus em Aspectos das artes

\footnotetext{
${ }^{33}$ O salário mínimo, em 26 mar 1968 valia NCr\$ 129,60. Assim, a quantia estabelecida para o acervo de Mário de Andrade equivale a quase 4.000 salários mínimos. Guia trabalhista. Disponível em: < http:// www.guiatrabalhista.com.br/guia/salario_minimo_1940a1999.htm>. Acesso em: 25 jan. 2012

34 Ibidem, p. 59 e 65.

${ }^{35}$ BATISTA, Marta Rossetti. ABC do IEB: guia geral do acervo. São Paulo: Edusp/IEB-USP, 1997.

${ }^{36}$ ANDRADE, Mário de. Do Desenho. In.: POHLIT, Claudéte I. Kronbauer. Mário de Andrade: cronista crítico das artes plásticas. São Paulo: FFLCH-USP, 1996. (dissertação de mestrado), pp. 275-278.
} 
plásticas no Brasil, de 1965. Para a apresentação do álbum Mangue de Lasar Segall, em $1943^{37}$, o escritor aprofunda e amplia questões ligadas ao tema.

A argumentação do escritor parte da definição que "o desenho fala, chega mesmo a ser muito mais uma espécie de escritura, uma caligrafia, que artes plásticas". Por um lado, sua finalidade o aproxima da palavra escrita; por outro, sua realização avizinha-se das artes plásticas. Logo, o desenho seria arte intermediária, entre as artes do tempo, poesia e prosa, e artes do espaço, escultura e pintura ${ }^{38}$.

Pela finalidade literária, Mário de Andrade aproxima o desenho a um grafismo, com caráter aberto, o que o levaria a "inerente liberdade [...] mais legível que a pintura". O desenho estaria ligado ao sentimento do indivíduo, ao seu interior, e, portanto, liberto de "moldura, composição, equilíbrio", sem limites exteriores ${ }^{39}$.

Em consequência, os "desenhos são para a gente folhear, são para serem lidos que nem poesias". Seria um contra-senso colocá-los em moldura, já que nem mesmo o papel ou a margem impõe qualquer limite ao desenho ${ }^{40}$. Em 1943, quando escreve o texto para o álbum de Segall, Mário de Andrade acrescenta, ao rol do desenho, as gravuras, uma vez que, em essência, participa de sua natureza literária. E continua, ao falar sobre o manuseio dos papéis:

Todo desenho legítimo dança, balouça dentro do quadro e nada tem a ver com os limites externos deste. E é soltos em nossas mãos-intempéries, manuseáveis de qualquer forma no tremor dos dedos e do espírito, que desenhos e gravuras se expandem em suas sublimes excelências de expressão. ${ }^{41}$

Mário de Andrade ciente de suas possibilidades econômicas, em carta a Manuel Bandeira de 9 de janeiro de 1935, prefere escolher um desenho quando Portinari lhe oferece um de seus trabalhos, justificando-se "Quadro não posso colecionar, dinheiro não dá e desenho (que é minha paixão mesmo em plástica) posso e tenho umas duas centenas, por aí" ${ }^{42}$.

Em relação à pintura e escultura, a procura se dá em "descobrir e representar a eternidade, por meio da matéria: tinta a óleo, têmpera" ${ }^{43}$. Dessa forma, a interação entre a obra de arte e o indivíduo, seja ele o próprio artista ou o fruidor, há que ser direta, sem

${ }^{37}$ MANGUE. Rio de Janeiro: Editora Revista Acadêmica, 1943. Álbum contendo 42 reproduções de desenhos originais de Segall, impressos em zincografia, 3 xilogravuras e 1 litografia originais, assinadas pelo artista. Textos de Jorge de Lima, Mário de Andrade e Manuel Bandeira. Disponível em < http:// www.museusegall.org.br/mlsTexto.asp?sSume=13>. Acesso em 25 jan. 2012.

Este ensaio de Mário de Andrade foi publicado postumamente pela Revista Acadêmica, Rio de Janeiro, no 66, nov. 1945, conforme POHLIT, Claudéte I. Kronbauer, op. cit., pp. 321-327.

${ }^{38}$ ANDRADE, Mário de. Do Desenho. Aspectos das artes plásticas no Brasil. São Paulo: Livraria Martins Editora, 1965, p.71.

${ }^{39}$ ANDRADE, Mário de. In.: POHLIT, Claudéte I. Kronbauer, op. cit., pp. 321-322.

${ }^{40}$ ANDRADE, Mário de, op. cit., pp. 71 e 74.

${ }^{41}$ ANDRADE, Mário de. In.: POHLIT, Claudéte I. Kronbauer, op. cit., p. 325.

42 CORRESPONDÊNCIA Mário de Andrade \& Manuel Bandeira / Organização, introdução e notas Marcos Antonio de Moraes. São Paulo: EDUSP / IEB USP, 2a ed., 2011, p. 608.

${ }^{43}$ ANDRADE, Mário de, op. cit., p. 75. 
qualquer interferência. Assim, é possível experimentar a consistência física e a patina do tempo, que "acrescenta um valor estético maravilhosamente sensível" ${ }^{4}$. O poeta pondera que o verniz da pintura seria uma proteção "indevida e cruel". Possivelmente pela alteração cromática ao oxidar, arrancando a cor da camada pictórica. Mesmo o uso de vidros na frente dos quadros, não seria algo desejável, o que se justifica diante do tipo de vidro, à disposição naquele período.

Ao contrário da pintura, "o vidro realçaria o valor do pastel e da aquarela", tratados separadamente porque são entendidos como "processos intermediários entre a pintura e o desenho". A moldura envidraçada serviria como uma caixa de ressonância, aumentando a sua intensidade artística ${ }^{45}$.

Por meio da concepção do colecionador das artes do tempo, do espaço e daquelas que estão no meio destas, compreendem-se as destinações de sua coleção de artes plásticas para duas instituições diversas.

Mário de Andrade destinaria seus desenhos e gravuras para a Biblioteca Municipal, pois se aproximam dos tipos impressos nos livros e, também, da sua inerente liberdade. Destarte, há o entendimento amplo de leitura, que "não é tanto adquirir noções, como contemplá-las" ${ }^{46}$. É digno de atenção que a destinação de Mário de Andrade, permitiria a constituição de um amplo conjunto de arte para a Biblioteca Municipal, que em 1945, inauguraria sua Seção de Artes ${ }^{47}$.

Os quadros e esculturas seguiriam para a Pinacoteca, que juntamente com o Museu Paulista, eram os únicos museus com obras de arte de São Paulo ${ }^{48}$. O perfil deste museu de arte, àquela altura, era essencialmente acadêmico, com o conjunto de obras provenientes da exposição francesa realizada em 1913, dos espólios de Henrique Bernardelli e de Pedro Alexandrino.

Quando as coisas desta terra se mantiveram como conjunto e seguiram para o IEB, tanto pintura e escultura quanto desenhos e gravuras ficaram integrados formando a série artes plásticas da coleção Mário de Andrade, trabalhada em termos museológicos pela Coleção de Artes Visuais, tal e qual outras instituições culturais e museus com acervo artístico.

Na composição atual do IEB, os livros de "luxo" com ilustrações são tratadas tal como as coleções bibliográficas ${ }^{49}$, entretanto possuem uma grande quantidade de gravuras, ora soltas, ora costuradas pela encadernação. Seria meritório um estudo, com o

${ }^{44}$ ANDRADE, Mário de. In.: POHLIT, Claudéte I. Kronbauer, op. cit., p. 325.

45 Ibidem.

${ }^{46}$ NOGUEIRA, Arlinda Rocha; BELLOTO, Heloísa Liberalli; HUTTER, Lucy Maffei; CARDOSO, Maria Cecília de Castro, op. cit., p.15.

${ }^{47}$ Em relação às artes plásticas, o projeto do Departamento de Cultura previa espaços destinados "ao fazer artístico e à difusão". O Teatro Municipal abrigaria ateliês para "núcleos atuantes, reunindo artistas e iniciantes". Apenas em 1940, a "parte inferior do Viaduto do Chá, tivera adaptações do local para ações sistemáticas de ensino e difusão, contudo reduziu-se a um local de exposição do Salão Paulista e do Sindicato, sem atividades permanentes de ensino como projetado". LOURENÇO, Maria Cecília França. Operários da modernidade. São Paulo: HUCITEC / EDUSP, 1995, p. 211.

${ }^{48}$ NASCIMENTO, Ana Paula. Espaços e a representação de uma nova cidade: São Paulo (1895-1929). São Paulo: FAU USP, 2009. (tese de doutorado)

49 A Biblioteca do IEB identifica cada livro, incluindo esses, de acordo com o sistema Dewey - classificação dividida por amplo espectro de classes ou categorias. 
estabelecimento de critérios de interesses diversos, como museal, estético, relacional, entre outros, que incorporassem estes volumes ao setor de artes plásticas ${ }^{50}$.

\section{Destino da sua coleção: uma Universidade}

Para levantar questões relativas às coisas desta terra, a definição de coleção por Krzysztof Pomian elaborou conceitos e definições significativos, acrescentando importantes aspectos aos vigentes no campo da Norma de Descrição Arquivística. Para este filósofo e historiador, coleção é o "conjunto de objetos naturais ou artificiais, mantidos temporária ou definitivamente fora do circuito das atividades econômicas, sujeitos a uma proteção especial num local fechado preparado para esse fim, e expostos ao olhar do público" ${ }^{51}$.

A retirada do objeto do circuito é justificada por várias maneiras: prazer estético, formação de repertório, aquisição de conhecimentos históricos e científicos; no entanto Pomian considera todas estas razões insuficientes para análise, pois a formação da coleção é uma característica humana e ultrapassa "as fronteiras da nossa sociedade" ${ }^{52}$. Considerandose ainda que sejam inerentes ao objeto vários tempos: aquele de seu surgimento como coisa desta terra; o momento em que se toma consciência no presente; e, o intervalo interposto pelos dois ${ }^{53}$. Assim como para o tempo, a mesma análise vale para o espaço, de tal forma que a exposição ao olhar, traz consigo todos estes elementos ao espectador.

Para Pomian, os diferentes tempos e espaços constituem o invisível, lugar de proveniência das coleções, que, portanto, intermedeiam "o espectador que as olha e o invisível de onde vêm" ${ }^{54}$. Deste modo, "as coleções participam no intercâmbio que une o mundo visível e o invisível" ${ }^{55}$, permitindo a aproximação entre estas duas esferas a partir de um espectador; portanto, não são nem únicas, nem comuns, para todas as culturas.

$\mathrm{O}$ historiador para distinguir os objetos úteis daqueles que representam o invisível define o termo semióforo quando duas características são alcançadas. A primeira é "quando se torna uma peça de celebração; a segunda, mais importante, é que a utilidade e o significado são reciprocamente exclusivos: quanto mais carga de significado tem um objeto, menos utilidade tem, e vice-versa" ${ }^{56}$.

Levando-se em conta o aparato teórico contido no texto de Pomian, a coleção de artes de Mário de Andrade realiza a interação entre o visível e o invisível, convertendo-a em peças

\footnotetext{
${ }^{50}$ Um exemplo é a edição de 1939 de Les Chants de Maldoror, escrito entre 1868 e 1869, pelo Conde de Lautréamont, que foi uma obra com certa influência entre os surrealistas. A edição de Mário é a de número 65 , do total de 210, todas assinadas por Salvador Dalí, que realizou uma série de 42 gravuras. Este exemplar fora presente de Cândido Portinari, conforme carta de agradecimento que Mário enviara em 3 de maio de 1938. In: Portinari, amico mio: cartas de Mário de Andrade a Portinari. FABRIS, Annateresa (org.). Campinas / Rio de Janeiro: Mercado de Letras, Autores Associados / Projeto Portinari, 1995, p. 60. Outro exemplo é o próprio álbum de Lasar Segall, com o texto $O$ desenho.

${ }^{51}$ POMIAN, Krzysztof. Colecção. In.:Enciclopédia Einaudi - 1. Memória-História. Porto: Imprensa Nacional/Casa da Moeda, 1985, p. 53.

52 Ibidem, p. 54.

${ }^{53}$ BRANDI, Cesare. Teoria del restauro. Torino: Eunaudi, 2000, p. 21.

${ }^{54}$ POMIAN, op. cit., p. 64.

55 Ibidem, p.66.

${ }^{56}$ Ibidem, p.72.
} 
de celebração de um momento em que fora protagonista, e repleta de significação; o que vale dizer, transformá-la em semióforo. Para Mário de Andrade, o invisível talvez pudesse ser a importância do modernismo na atualização de valores; a acessibilidade por distintos públicos, a disseminação da cultura em diversos suportes; os valores da paulistaneidade, ou ainda a memória coletiva de seus tempo registrada em suas coisas da terra.

A consciência que Mário de Andrade tinha de seu papel e de sua força ativa no movimento moderno, dedicando-se "feliz a problemas do meu [seu] tempo e minha [sua] terra" ${ }^{57}$, bem como do que ajuntara durante a vida, observa-se no desejo de publicizar sua coleção, conforme palavras suas "dôo apenas porque nunca colecionei pra mim, mas imaginando me constituir apenas salvaguarda de obras, valores e livros que pertencem ao público, ao meu país, ao pouco que eu gastei e me gastou" ${ }^{58}$.

Quando escreveu sobre o colecionador Alberto Lamego, talvez Mário de Andrade já antevisse o sentimento suscitado pelas coleções em geral e a sua própria em particular:

Não foi sem melancolia que Alberto Lamego deixou partir o que ajuntara. Surpreendi-o por várias vezes dialogando comigo verdadeiros monólogos de consolação. O historiador da Terra Goitacá recordava nesses momentos o perigo de dispersão desse acervo que, em sua parte essencial, a Brasiliana, é de uma escolha excelente.

E Alberto Lamego logo se animava lembrando o destino da sua coleção de livros: uma Universidade. Essa lembrança era o melhor arrimo das suas melancolias ao par do movimento cultural paulista, o ilustre fluminense compreendia que esse pouso final dos seus livros era um começo de nova espécie, que não deixava de o enaltecer. ${ }^{59}$

Antes da chegada de seu acervo à Universidade, Mário de Andrade havia sido convidado pelo Prof. André Dreyfus, então diretor da Faculdade de Filosofia Ciências e Letras, a concorrer à cadeira de literatura, contudo não aceitara. Fora ainda convidado para fazer parte da banca, mas novamente outra recusa ${ }^{60}$. Talvez a deixar seu joelho apoiar-se na Universidade, apenas com a vinda das coisas da terra.

A chegada à Universidade de sua coleção fomentou inúmeras pesquisas e projetos, dentre os quais ressaltamos aquela relativa à série artes plásticas, qual seja, a sua catalogação realizada por Marta Rossetti Batista e Yone Soares de Lima. A publicação resultante deste trabalho é o catálogo de 1984, revisado e ampliado em 1998. Cada uma das 667 obras foi identificada, inventariada, pesquisada, assim todas foram contempladas com

${ }^{57}$ ANDRADE, Mário de. Aspectos da literatura brasileira. 6o ed. Belo Horizonte: Editora Itatiaia, 2002, p. 277.

58 ALVARENGA, Oneyda. Mário de Andrade, um pouco. Rio de Janeiro/São Paulo: José Olympio/Conselho Estadual de Cultura, 1974, p.35.

${ }^{59}$ ANDRADE, Mário de. A Biblioteca Lamego. In. NOGUEIRA, Arlinda Rocha; BELLOTO, Heloísa Liberalli; HUTTER, Lucy Maffei; CARDOSO, Maria Cecília de Castro, op.cit., pp. 16.

${ }^{60}$ SOUZA, Gilda e Antonio Candido de Mello e. A lembrança que guardo de Mário. In: Revista do Instituto de Estudos Brasileiros, São Paulo, 36, 1994, p. 14. 
seus respectivos verbetes contendo: autoria, título, técnica, dimensão, data, presença ou não de assinatura, de inscrições, além de levantamento em participação de exposições. Grande parte foi fotografada, nestes casos sua reprodução acompanha os verbetes, em consonância com as normas então propostas, em especial nos campos da arquivística, museologia e história da arte.

A ordenação das obras no catálogo se deu pela autoria. Assim os artistas, com obras produzidas na primeira metade do século $X X$, são indexados por ordem alfabética, primeiro os nacionais, ou cuja atuação tenha sido no Brasil, depois os estrangeiros, seguidos pelos não identificados. Apenas uma pequena parcela é anterior a este período, o equivalente a 32 itens. Agrega-se, à catalogação item a item, a biografia de todos os artistas que estejam representados nesta série.

Um de seus objetivos "visa contribuir para o estudo da História da Arte no Brasil" 61 , para isso, a análise, peça a peça, fornece elementos para inseri-la no arco temporal das artes plásticas do entre - guerras. Todavia, a separação das obras de uma mesma autoria, se encontra em consonância com critérios da técnica artística, possivelmente pela dificuldade em assegurar a datação precisa. Por outro lado tal opção chama a atenção para o material, o instrumento e o manejo, valorizando uma materialidade, em geral pouco interpretada.

Marta Rossetti e Yone de Lima delineiam dois agrupamentos, denominando-os primeira geração - os modernistas e segunda geração - anos 30/40. ${ }^{62}$. Esta divisão temporal, em linhas gerais, acompanha o próprio entendimento de Mário de Andrade sobre o período, em sua conferência lida no Ministério das Relações Exteriores do Brasil, em 30 de abril de 1942: O movimento modernista. O intelectual, como antes se esclareceu e diferentemente das autoras, divide o primeiro tempo em dois: fase heroica (1917-1922) ${ }^{63}$ com a fase destruidora ${ }^{64}$ ou orgia intelectual ${ }^{65}$ (1922-1930). Mantendo a seguinte como fase de construção ou proletária $(1930-1945)^{66}$. É notório que, com outras nomenclaturas, estas datas coincidem com as adotadas, posteriormente, pelo Prof. Walter Zanini em seu estudo sobre o que correspondia, naquele momento, à Arte Contemporânea ${ }^{67}$. É dada a preferência à divisão temporal sugerida por Mário de Andrade, pois se entende que a coleção reflete seu colecionador.

${ }^{61}$ BATISTA, Marta Rossetti e LIMA, Yone Soares de. Coleção Mário de Andrade. Artes Plásticas. São Paulo: IEB USP, 1984, p. XXII.

${ }^{62}$ Esta divisão acompanha a classificação adotada quando da exposição e posterior publicação Brasil: 1ㅇ Tempo Modernista - 1917/29: documentação publicação que objetivava reunir documentação que subsidiasse "o estudo do Modernismo". BATISTA, Marta Rossetti; LOPEZ, Telê Ancona; e LIMA, Yone Soares de. Brasil: 1o Tempo Modernista - 1917/29: documentação. São Paulo, IEB USP, 1972, p. 2.

${ }^{63}$ ANDRADE, Mário de. 0 movimento modernista, op. cit., p. 260.

${ }^{64}$ Ibidem, p. 260.

${ }^{65}$ Ibidem, p.261.

${ }^{66}$ Ibidem, p. 265.

${ }^{67}$ O historiador segue seu estudo pelas décadas de 1950, 60 e 70. Zanini, Walter. Arte Contemporânea. (org.). História geral da arte no Brasil. São Paulo: Instituto Moreira Salles, 1983, pp. 500-501. 


\section{Gênese do colecionador}

Para a Prof. a Gilda de Mello Souza, no referido catálogo de artes plásticas, o poeta de Paulicéia Desvairada fala "de si, mesmo quando parecia profundamente imerso na meditação sobre o Brasil" ${ }^{68}$. Criaria, dessa forma, uma reunião de objetos à sua imagem e semelhança, na qual "o colecionador descansa na coleção" com o intuito, não do lucro ou do status, e sim "chegar mais perto do Homem e do mundo" para que pudesse "refazer o grande puzzle de sua vida, de sua época" ${ }^{69}$. Corroboram nesse sentido, Marta Rossetti e Yone Soares ao perceber que "a primeira mola do colecionador é o desejo de possuir as obras que o comovem", juntamente há "a intenção de documentar-se, registrando sua época e seu grupo" 70 .

Dessa forma, as pesquisadoras colocaram o colecionador, o intelectual, o escritor, o homem público, o musicista, o professor e o crítico inseridos e confrontados à sua coleção, de tal forma a identificar-se nela, as diferenças etapas de sua vida. Todavia, ainda fica a questão, em que momento se dá a primeira idéia de juntar coisas desta terra? Como nasce o colecionador? Quais os fatores? Em que tempo e espaço? Onde? Por quê? Qual é o espelho para essa coleção? São formulações de respostas categóricas improváveis, mas que fornecem outro campo igualmente significativo de discussões acerca do tema, ensejando desnaturalizar a coleção e apartar-se da postura discutível de transformar as peças em ilustração de marcos ou meros fetiches e ícones a serem venerados.

Dos modelos de colecionismo existentes em São Paulo, no início do século XX, nos quais Mário de Andrade poderia eventualmente espelhar-se, foram escolhidos aqueles de Dona Olívia Guedes Penteado e José de Freitas Valle ${ }^{71}$. Essa seleção se deve às ligações do autor de Macunaíma a essas e outras figuras então notórias na oligarquia paulistana.

Após a Semana de Arte Moderna, na visão de Mário, principiou-se o "movimento dos salões" 72 , que seriam os: da Rua Lopes Chaves; de Paulo Prado, na Avenida Higienópolis; de Tarsila do Amaral, na Alameda Barão de Piracicaba; e, de Dona Olívia Guedes Penteado, na Rua Duque de Caxias. Mário de Andrade frequentava todas as terças vespertinas, os encontros no Pavilhão de Arte Moderna da aristocrata.

Já a Villa Kyrial, propriedade na Vila Mariana de Freitas Valle, não fora citada por Mário de Andrade em sua conferência de 1942. A tese de doutorado sobre o tema revela aspectos pitorescos a respeito desse curioso esquecimento, uma vez que o escritor do $O$ movimento modernista, às vésperas da Semana de Arte Moderna, o definira como "o único salão organizado, o único oásis a que a gente se recolha semanalmente, livrando-se das falcatruas

${ }^{68}$ SOUZA, Gilda de Mello e. O colecionador e a coleção. In: BATISTA, Marta Rossetti e LIMA, Yone Soares de, op. cit., p. XII.

69 Ibidem, p. XVI.

${ }^{70}$ BATISTA, Marta Rossetti e LIMA, Yone Soares de, op. cit., pp. XXIII e XXVI.

${ }^{71}$ Acerca de outras coleções consultar: MICELI, Sergio. Nacional estrangeiro: história social e cultural do modernismo artístico em São Paulo. São Paulo: Companhia das Letras, 2003; e, também, RIBEIRO, Maria Izabel M. Reis Branco. Museu doméstico: São Paulo, 1890-1920. São Paulo, ECA USP, 1992. (dissertação de mestrado).

${ }^{72}$ ANDRADE, Mário. O movimento modernista. Op. cit., p. 261. 
da vida chã" ${ }^{73}$. Inclusive participara dos ciclos de conferências de 1921, 1922 e 1923, além de contatos fortuitos durante a década seguinte.

Freitas Valle seria uma figura aristocrática com ligação direta ao poder político, até os anos 1930. Com a mudança de governo, a Villa Kyrial "esvaziou-se da sua capacidade geradora de capital simbólico". Dessa forma, a autora conjectura "sobre as motivações psicológicas, ressentimentos ou diferenças pessoais de Mário de Andrade" e conclui que este, por não possuir autonomia financeira, "via-se na contingência de cortejar os poderosos do dia" ${ }^{74}$. É importante lembrar que Freitas Valle fazia parte da Comissão Fiscal do Pensionato Artístico ${ }^{75}$, no qual era figura soberana nas decisões de agraciamento de bolsas.

Segunda a pesquisadora, as obras acadêmicas seriam a predileção de Freitas Valle as obras acadêmicas, porém "revelava certa abertura estética para o novo e uma fina percepção artística", formando uma coleção comprada ora em viagens e leilões, ora em mostras que se realizavam em São Paulo ${ }^{76}$. Poderia ainda ser presentes de amigos ou artistas em retribuição aos auxílios recebidos ou futuros. Além dos itens que os pensionistas Ihe enviavam como exemplares de seu desempenho ${ }^{77}$.

Dessa forma, a coleção Freitas Valle se compunha de um agrupamento de "artistas franceses e espanhóis, de artistas acadêmicos cariocas e paulistas de prestígio, de artistas estrangeiros com exposições frequentes na capital paulista, de antigos pensionistas e de alguns poucos artistas da primeira geração modernista" ${ }^{78}$. E também se espelhava na própria diversidade da Pinacoteca do Estado, a que estava ligado ${ }^{79}$. Este conjunto revestia as paredes de alto a baixo, em que os quadros pendiam em ângulo, de modo a facilitar sua visualização. "Com molduras douradas ricamente entalhadas e próximas uns dos outros a ponto de perderem a individualidade, diluíam-se no fundo estampado, tornando-se parte de um verdadeiro mosaico" ${ }^{80}$.

Como habitualmente em outras, esta coleção seguia uma via de mão dupla entre o privado e o público, porquanto, no desempenho de suas funções políticas, mantinha-se "à frente da gestão do programa estadual de subsídios governamentais" juntamente com "o retorno dessa aplicação de recursos públicos pelas aquisições de obras dos artistas contemplados com bolsas a preços depreciados" ${ }^{81}$.

Ao adotar como referenciais colecionistas, Dona Olívia Guedes Penteado e o Senhor da Villa Kyrial, Mário de Andrade incorpora práticas, dentro de suas possibilidades financeiras,

73 ANDRADE, Mário de. Ilustração Brasileira, ano 8, no 9, Rio de Janeiro, maio de 1921. In: Cinco crônicas de Mário de Andrade. LOPEZ, Telê Ancona (introd., org. e notas). São Paulo: Editora Senac, 2004, p. 112.

${ }^{74}$ Ibidem, pp. 189-193.

75 Instituição criada em 1912, para promover o desenvolvimento da produção artística no Estado paulista por meio de concessão de bolsas de estudos para estudantes seguirem sua formação na Europa.

${ }^{76}$ Devido a sua posição, a elite não só comprava, como também patrocinava, muitas dessas mostras. CAMARGOS, Marcia. Villa Kyrial: crônica da Belle Époque paulistana. 2ª ed. São Paulo: Editora SENAC, 2001, p. 176.

77 Ibidem, pp. 46 e 56.

${ }^{78}$ MICELI, Sergio. Nacional estrangeiro: história social e cultural do modernismo artístico em São Paulo. São Paulo: Companhia das Letras, 2003, p. 72.

${ }^{79}$ LOURENÇO, Maria Cecília França. Catálogo geral de obras da Pinacoteca do Estado. São Paulo: Imesp, 1988.

${ }^{80}$ CAMARGOS, p. 56.

${ }^{81}$ MICELI, op. cit., p. 61. 
tais como: seguir as mãos de quem estava no exterior, como Tarsila do Amaral e Oswald de Andrade desfrutando do acesso direto com as vanguardas francesas, comprar em mostras ocorridas na cidade de São Paulo obras, principalmente, de artistas coetâneos. Além disso, estes salões possibilitaram a exposição ao olhar em ambientações ímpares, ora Pavilhão Modernista de Dona Olívia, como se verá adiante, ora no mosaico de Freitas Valle, como, porque não, de ensino dado pelas manifestações artísticas, que vai ao encontro do lado professoral de Mário de Andrade.

Pode-se supor que a não diferenciação entre o público e o privado, vale dizer, os múltiplos interesses, muitas vezes conflitantes, adotados por Freitas Valle e tantos outros, insere-se no imaginário de Mário de Andrade. Isso fica patente não só na destinação pública de sua coleção, como também na necessidade de se criar um campo artístico, com instituições capazes de receber a produção de arte do movimento modernista, numa São Paulo com escassas opções museológicas. Objetivo que tentara alcançar quando estava no Departamento de Cultura.

Quaisquer desses espelhos trazem consigo um obstáculo intransponível: a diferença de classe social entre estes e Mário de Andrade, colocando-os em mundos distantes, conforme revela a Manuel Bandeira em 19 de maio [de 1924]:

Creio também que o que está me fazendo mal são as companhias. Meu grupo, amigos, camaradas, todos ricaços, sem preocupações. Há um eterno conflito entre mim e eles. Isso deprime. [...] Mas há conflito. Dona Olívia me convida para um chá... Vai ser delicioso, eu sei. Que companhia! Tão harmônica, tão bela! Divertir-me-ei muito. [...] Mas às 19 horas tenho minha lição no Conservatório. [...] Mas como farra sem dinheiro? Não vou, que não ando pago pelos outros. Um café que me paguem me ofende. Preciso largar dessa gente. Mas como? se são os que eu amo, os que me amam? E não é possível inculpá-los de qualquer coisa. Não são indiferentes. Já o demonstraram. Mas eu não aceito, sou incapaz de aceitar. Daí o conflito. Meu continuado conflito. [...] $]^{82}$

No viés da origem colecionista, Mário de Andrade refere-se à primeira obra comprada, possivelmente ainda na década de 1910, em carta a Oneyda Alvarenga de 14 de novembro de 1940:

[...] como estudava piano, não perdia um concerto e lia a vida dos músicos, também não perdia exposições plásticas, devorava histórias de arte, me atrapalhava em estéticas mal compreendidas, estudava os escritores e a língua, e, com que sacrifícios nem sei pois vivia de mesada miserável, comprava o meu primeiro quadro! Por sinal que, não caçoe, eram umas ninfeáceas roxas num lago, com um fundo de grandes árvores

${ }^{82}$ CORRESPONDÊNCIA Mário de Andrade \& Manuel Bandeira, op. cit., p. 122. 
florestais, obra de Torquato Bassi!! não caçoe, menina. Mas eu amei aquela água que parecia profunda mesmo. ${ }^{83}$

Ao descrever sua primeira aquisição, o que seria uma espécie de mito fundador de sua coleção, o musicólogo aponta para, além da comoção, a necessidade de um aparato relativo ao conhecimento e ao estudo, mesmo que mal compreendidos.

Ainda sobre esse episódio, Mário de Andrade o descreve por meio da personagem Siomara Ponga de $O$ Banquete, refletindo-se nela seu "episódio autobiográfico" ${ }^{84}$ :

[...] Em criança, quando eu ia a pé para o colégio, era obrigada a atravessar o centro da cidade, eu era pobre... Mas parava sempre em tudo quanto era exposição de pintura. Uma feita, numa dessas, me engracei dominadoramente por um quadro do pintor Donato Bassi. ${ }^{85}$

Mesmo que o nome de Torquato Bassi tenha sido alterado, é inegável que se trate dele quando, mais a frente, descreve a pintura:

Eram umas ninfeáceas roxas, numa água profunda, e com um tecido de arvoredo verde-negro no segundo plano. Hoje eu rio, mas como eu achava aquela água morta verdadeira... O quadro custava cinquenta mil réis, mas o pintor acabou deixando pelos quinze que eram toda a minha mesada...

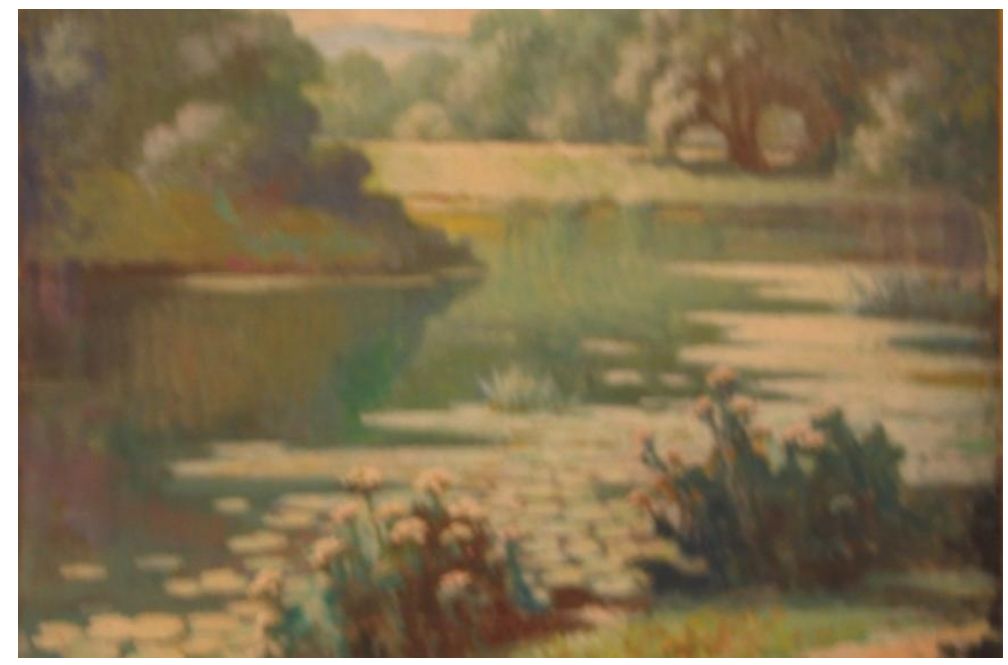

Imagem 1. BASSI, Torquato. Lagoa tranqüila. óleo sobre tela, $72.5 \times 84.0 \mathrm{~cm}$.

Fonte: Pinacoteca do Estaco de São Paulo. Obra doada por Isolda Silla Bassi Bruch, em 2002.

E foi justamente o aprofundamento da sua aprendizagem, a militância contra o tradicionalismo, nas soluções pictóricas, repetindo-se soluções consagradas e sem se arriscar

${ }^{83}$ Mário de Andrade, Oneyda Alvarenga: cartas. São Paulo: Duas Cidades, 1983, p. 271.

${ }^{84}$ COLI, Jorge; DANTAS, Luiz Carlos da Silva. Sobre O Banquete. In: ANDRADE, Mário. O Banquete. São Paulo: Duas Cidades, 1977, p. 26.

${ }^{85}$ ANDRADE, Mário. O Banquete. São Paulo: Duas Cidades, 1977, p. 90. 
no desconhecido, vale dizer jogar no certo, que o levou a eliminar, o que poderia ser considerado, mito fundador de sua coleção:

Depois com o apuramento dos estudos, principiei tendo vergonha do quadro sem pintura que acabei dando não lembro a quem. Hoje, nem sei quanto pagava pra obter o quadro outra vez, só pra sonhar diante do meu primeiro passado de vida real...

Arrepende-se ao final de ter descartado o quadro de sua coleção, pois fazia parte das coisas desta terra que lhe despertavam emoção. O valor sentimental reflete assim, o próprio colecionador em outros tempos, o que lhe traria a sensação de seus primeiros contatos com a arte.

A consciência artística viria então com quadros de cunho modernizante, em especial por Anita Malfatti e Victor Brecheret, conforme narrado no O movimento modernista, e, também descrito em $O$ Banquete. É interessante ressaltar que a personagem Siomara Ponga atribui ao Homem amarelo, de Anita Malfatti, "a sensação estética permanece e revive toda vez que contemplo o quadro ou penso nele" ${ }^{86}$. O moderno parece já se tornar eterno, reconhecido e sem perder seu caráter transgressor.

${ }^{86}$ Ibidem. 


\section{Prefácio Interessantíssimo da coleção}

Mário de Andrade já faz referência a sua coleção nos primeiros anos da década de 1920. No poema Reza de fim de ano, para a passagem de 1923 ao ano de 1924, enviado a Anita Malfatti, o poeta considera a existência de sua coleção:

Eu te agradeço este ano que me deste.

Que o novo seja igual ao que passou!

Alegrias bombásticas

Sofrimentos redundantes

Retumbantes

Samba

Villa-Lobos

Os meus amigos de Paris

Águas-fortes de Seewald

Águas-fortes de Chagall

Sangue

Pranto e riso

Quanta coisa! Quanta coisa!..

Vós tereis o bronze... Vós tereis a minha lembrança... Vós tereis a minha coleção de águas-fortes... ${ }^{87}$

A primeira escultura a entrar na coleção foi a Cabeça de Cristo causadora de tamanho impacto que, mesmo sem dinheiro, devendo, economizando até na tarifa do bonde, nas palavras do próprio colecionador, 'miquiado', recorreu a seu irmão, Carlos, para conseguir pagar a fundição em bronze desta peça. Possivelmente, a Fundição Artística de Bronze Roque de Mingo, um hábil artista e fundidor, proveniente do Liceu de Artes e Ofícios de São Paulo e responsável pela execução de muitas esculturas fúnebres presentes em cemitérios paulistas.

Com grande entusiasmo, Mário de Andrade a levou para casa; entretanto, a imagem de Cristo com trancinhas causou estardalhaço em sua família católica, que não admitia uma suposta profanação à figura sagrada. Mário de Andrade criou, a partir do ocorrido, os versos que há tempos o perseguiam ${ }^{88}$, publicados em Paulicéia Desvairada. As emoções do escritor durante a gênese desta criação estão no "Prefácio Interessantíssimo" e são descritas da seguinte maneira pelas palavras de Mário de Andrade: "que chorei, que cantei, que ri, que berrei... Eu vivo!" ${ }^{89}$.

87 BATISTA, Marta Rossetti (org.). Mário de Andrade, cartas a Anita Malfatti. Rio de Janeiro: Forense Universitária, 1989, pp.67-71.

${ }^{88}$ ANDRADE, Mário de. O movimento modernista, op. cit., pp. 255-256.

${ }^{89}$ ANDRADE, Mário de. Paulicea Desvairada. São Paulo: Casa Mayença, 1922, p.38. 

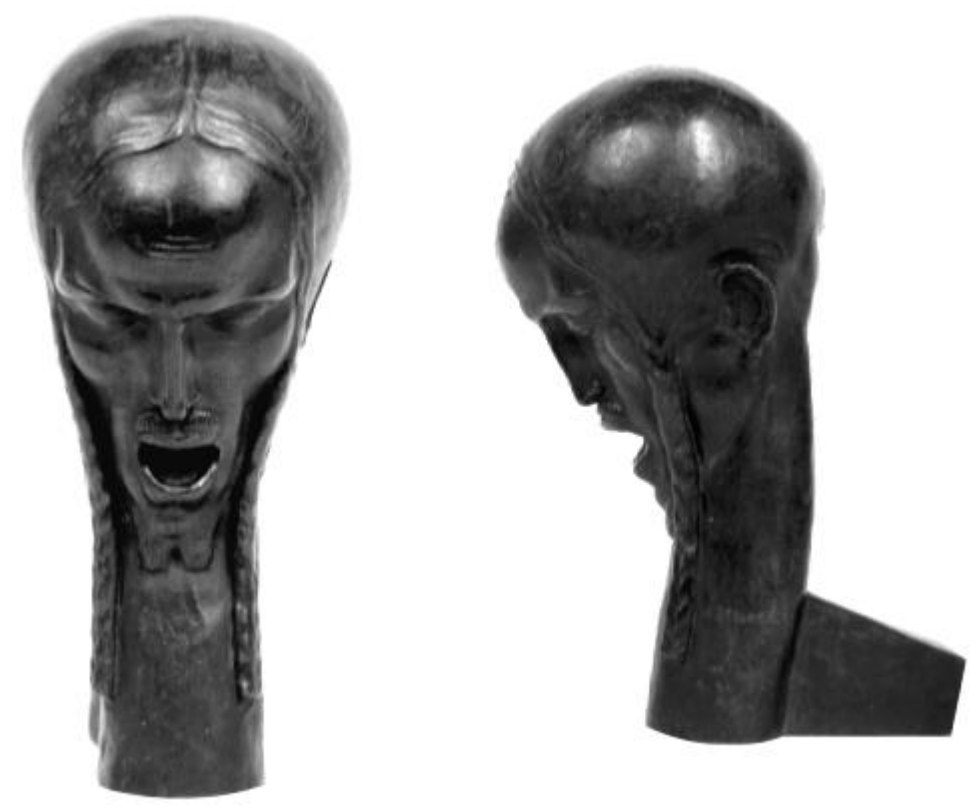

Imagem 2. Cabeça de Cristo de Victor Brecheret, 1919/20 c., bronze, $32.0 \times 14.0 \mathrm{~cm}$.

Fonte: Coleção Mário de Andrade - Coleção de Artes Visuais do Instituto de Estudos Brasileiros da USP.

Ainda em 1921, antes de Brecheret seguir para Paris, após ter sido contemplado com bolsa do Pensionato Artístico, Mário de Andrade manda outra escultura para a Fundição de Mingo; desta vez, seria a Vitória. Nas primeiras cartas enviadas a Mário, já em Paris, o escultor faz apologia à vitória ${ }^{90}$. É possível que se referisse ao reconhecimento e à consolidação de seu trabalho escultórico. Ou seria à "criação de um espírito novo" que exigisse "a reverificação e mesmo a remodelação da Inteligência nacional" ${ }^{91}$, que fora o movimento modernista em relação ao academismo. Ou ainda, quem sabe, uma brincadeira com seu próprio nome, Victor.

Já a denominação de águas-fortes ${ }^{92}$, possivelmente seria uma espécie de guarda-chuva para todos os tipos de gravuras em metal. Com recursos materiais modestos, apenas os papéis flexíveis estariam ao alcance do escritor de Paulicéia Desvairada, reconhecidamente com valores menores do que a tela esticada.

${ }^{90}$ Correspondência de Victor Brecheret a Mário de Andrade. Paris, 19 ago. 1922, e [Paris], [1923], pertencentes ao Fundo Mário de Andrade, códigos de referências: MA-C-CPL1479 e 1480, respectivamente.

${ }^{91}$ ANDRADE, Mário de. O movimento modernista, op. cit., pp. 253.

${ }^{92}$ A técnica água-forte é um tipo de gravura que se processa da seguinte forma. A matriz é de algum metal, ferro, zinco, cobre, alumínio, latão, revestido com verniz de proteção. Quando o gravador faz a incisão na placa, o verniz é retirado, sem, contudo, atingir a placa de metal que em seguida, é submersa em banho de ácido, corroendo e formando sulcos. Após esse processo, a placa é entintada e nos sulcos formados acumulase a tinta, que passará para o papel umedecido quando passar por prensa de rolo. 


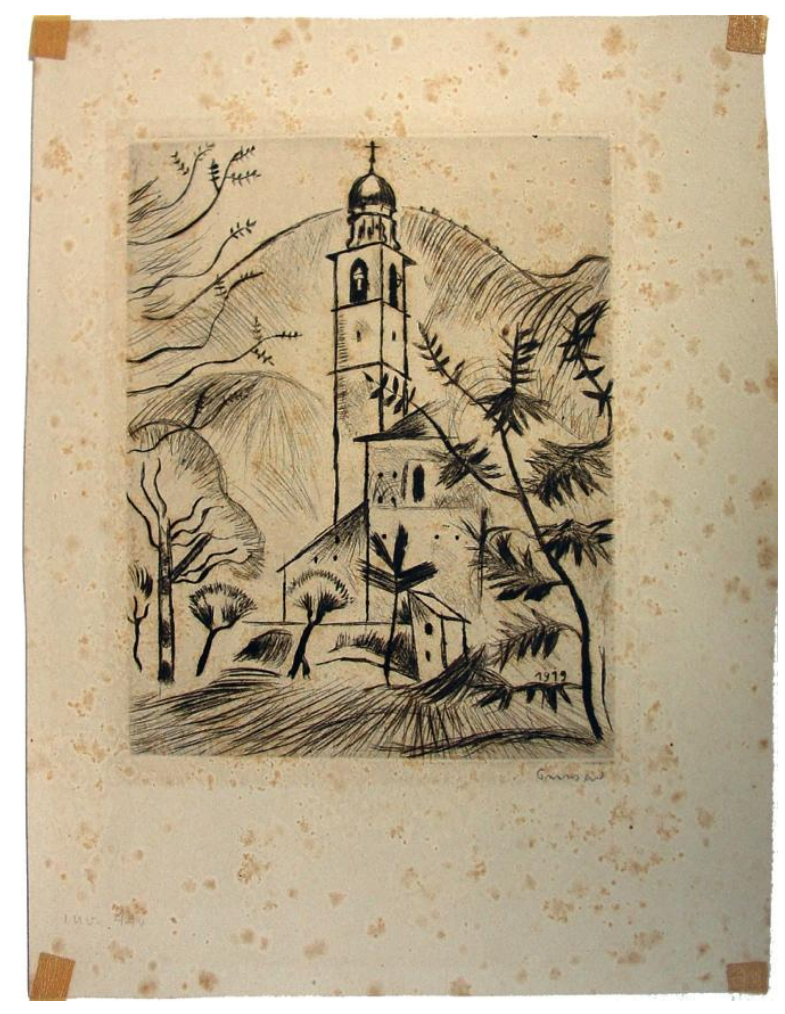

Imagem 3. Paisagem com igreja de Richard Seewald, gravura em metal sobre papel, $17.6 \times 13.7 \mathrm{~cm}$.

Fonte: Coleção Mário de Andrade - Coleção de Artes Visuais do Instituto de Estudos Brasileiros da USP.

Na direção das gravuras, a coleção aponta à Escola de Paris e aos alemães. Em relação aos primeiros, as mãos que Ihe encaminhavam eram: Sérgio Milliet e Tarsila do Amaral. São desse grupo: Pablo Picasso, Fernand Léger, Marc Chagall, André Lhote, Georges Valmier, Hermine David, Marie Laurencin, Natália Gontcharova, e Jean-Emile Laboureur. Inclui-se, além das gravuras soltas, os livros de luxo ilustrados por artistas, tais como: Foujita, Dufy, Gus-Bofa, Dignimont, Derain, Yves Alix, Hermine David, Mily Possoz, Marie Laurencin, Gontcharova, Laboureur, Pascin, De Chirico, Picabia e Salvador Dali ${ }^{93}$.

O primeiro contato com os alemães possivelmente tenha se dado com Anita Malfatti, ainda em 1917. Contudo, pouca relação possuía com as terras germânicas levando-o a procurar obras no Brasil, como as trazidas pelo colega de Anita, Henrich von den Hoff, ou ainda por Lasar Segall. Quem mais colaborou foi Theodor Heuberger ${ }^{94}$, que organizava exposições germânicas, nas cidades de São Paulo e Rio de Janeiro. Dos anos 1920, estão representados na coleção: Klaus Richter, Willy Jaeckel, George Ehrich, Ludwig Meidner. De 1930, Emil Orlik, cuja obra Beethoven estava exposta acima do piano para dar aulas na Rua Lopes Chaves. Ainda nessa direção, há Composição, de Paul Klee e de alemães radicados no Brasil, como Wilhelm Haarberg e Friedrich Maron ${ }^{95}$.

\footnotetext{
93 BATISTA, Marta Rossetti e LIMA, Yone Soares de, op. cit., p. XXVI.

${ }^{94}$ Marchand alemão que veio ao Brasil pela primeira vez em 1924, juntamente com exposição de pinturas e esculturas de artistas da Alemanha. Estabeleceu-se no Rio de Janeiro em 1928, tendo fundado a Sociedade Pró Arte de Artistas e Amigos das Belas Artes em 1931.

${ }^{95}$ BATISTA, Marta Rossetti e LIMA, Yone Soares de, op. cit., p. XXVII.
} 
A proximidade de Mário de Andrade com as artes gráficas, talvez suscitada, num primeiro momento pelas suas limitações financeiras, pode ter virado um interesse importante durante sua atuação no Departamento de Cultura. Durante sua gestão, o fomentador da cultura pesquisou equipamentos com gravadores brasileiros, no intuito de implantar "uma escola de gravura, dada a carência no setor, pensando em trazer professor estrangeiro, por tempo determinado, para implantar algo de qualidade". Esse projeto não foi implantado ${ }^{96}$.

Em 1933, Mário de Andrade recebera um elenco de 13 perguntas, na qual a segunda referia-se ao interesse em colecionar primeiras edições, a que o autor de Paulicéia Desvairada responde:

[...] coleciono grandes edições de luxo, em grandes papéis e ilustrados por grandes gravadores modernos. Possuo a primeira edição da ópera /l Guarany de Carlos Gomes; as Reise in Brasilien de Spix e Martius; a Voyage Pittoresque dans le Brésil de Rugendas, com as suas maravilhosas gravuras. [...] Entre as minhas edições modernas de grande luxo, prefiro as francesas, que são geralmente as mais completas quanto livro considerado como obra-de-arte. Assim as edições Les Algues, ilustradas por Alexeieff (Sieffried et le Limousin de Giraudoux, Bouddha Vivant de Morand). As Villes Tentaculaires ilustradas com litos de Brangwyn. A edição de Um amour de Swann de Proust, com as águas-fortes de Laprade, que é uma verdadeira obra-prima, como equilíbrio de tipografia e gravura, correspondentes ao estilo do escritor. E muitas outras mais, com gravuras de Picasso, de Léger, de Chirico, De Dunoyer, de Segonzac e outros grandes nomes da plástica modernista. ${ }^{97}$

\section{O colecionador e a salvaguarda de valores}

A mola do colecionador o impulsiona para outras vertentes, além de seus bronzes e águas-fortes: desenhos, aquarelas, guaches, nanquim, carvão, lápis, caneta, pastel, monotipias, telas, se multiplicam ao longo das diversas fases do 0 movimento modernista. Já em carta a Pedro Nava, de 23 de dezembro 1925, Mário de Andrade se refere à sua coleção ao solicitar um desenho "Me mande um preto e branco prá minha coleção" 98 .

Pelas diversas fases movimento modernista, o colecionador incorpora obras que seguem para além de seu tempo. Ainda da fase heroica, a coleção de Mário de Andrade abriga

\footnotetext{
${ }^{96}$ LOURENÇO, Maria Cecília França. Operários da modernidade. São Paulo: HUCITEC / EDUSP, 1995, p. 211.

${ }^{97}$ ANDRADE, Mário de. Entrevistas e depoimentos. Telê Porto Ancona Lopez (org.). São Paulo: T. A. Queiroz, 1983, p. 40.

98 ANDRADE, Mário de. Correspondente contumaz: cartas a Pedro Nava, 1925-1944. Edição preparada por Fernando da Rocha Peres. Rio de Janeiro: Nova Fronteira, 1982, p. 61.
} 
importantes obras de Anita Malfatti, quadros que o despertaram para o novo, após a exposição que ocorrera entre 12 de dezembro de 1917 a 10 de janeiro 1918. A artista já havia realizado estudos na Alemanha ${ }^{99}$, local em que acontecia o expressionismo, quando foi aos Estados Unidos, lugar em que experimentou a liberdade de criar: "a festa da forma e da cor" ${ }^{100}$. A escolha do colecionador foram telas emblemáticas, pois participaram desta exposição em 1917 e, também, da Semana de Arte Moderna, em 1922: A estudante russa (1915c.), O homem amarelo (1915/16) e O japonês (1915/16).

Quando Mário de Andrade conheceu as obras de Anita, riu descontroladamente, deixando a artista enfurecida. Dias depois, o colecionador voltou, sem riso, com um poema parnasiano intitulado $O$ homem amarelo, e a promessa que um dia iria buscar o quadro homônimo, que já o considerava seu ${ }^{101}$.

Em 1942, no balanço que faz em Movimento Modernista, Mário de Andrade dá crédito à Anita Malfatti utilizando-se da palavra revelação, mais afeita a uma esfera religiosa embora aqui agregada à plástica expressionista e cubista, a qual conhecia apenas de livros, numa São Paulo em transformação que culminaria na metrópole, conforme trecho abaixo:

Parece absurdo, mas aqueles quadros foram a revelação. $E$ ilhados na enchente de escândalo que tomara a cidade, nós, três ou quatro, delirávamos de êxtase diante de quadros que se chamavam "Homem Amarelo", a "Estudante Russa", a "Mulher de Cabelos Verdes". E a esse mesmo "Homem Amarelo" de formas tão inéditas então, eu dedicava um soneto de forma parnasianíssima... Éramos assim ${ }^{102}$.

Assim, entre a exposição de Anita Malfatti que ocorrera de 12 de dezembro de 1917 a 10 de janeiro 1918, e a Semana de Arte Moderna, durante os dias 13, 15 e 17 de fevereiro de 1922, os auspiciosos anos da fase heróica sopraram ventos vanguardistas em direção ao colecionador, quando viviam o "estado de exaltação [...] incontrolável. Qualquer página de qualquer um de nós jogava os outros a comoções prodigiosas, mas aquilo era genial!" ${ }^{103}$.

Dentro deste espírito, ocorrera a Semana de Arte Moderna que é extensivamente representada na sua coleção, mas que, curiosamente, não possuía o seu respectivo catálogo, ao contrário de tantos outros. Qual seria a razão desse lapso? No fundo algo a ser esquecido, por sua apresentação jocosa, ou por razões de foro íntimo? No Fundo Mário de Andrade, há apenas o Programa de palestras e de apresentações musicais, do qual faria parte durante palestra a ser proferida no saguão do Teatro Municipal, em 13 de fevereiro.

Por outro lado o mais complexo para seus recursos, ou seja, aquisição de peças participantes do evento congrega a coleção. Assim, excetuando-se Georg Przirembel, Hildegardo Leão Velloso, John Graz, Alberto Martins Ribeiro, os demais artistas que

${ }^{99}$ BATISTA, Marta Rossetti. Anita Malfatti no tempo e no espaço: biografia e estudo da obra. São Paulo: Editora 34 / Edusp, 206, p. 54.

100 Ibidem, 101.

${ }^{101}$ MALFATTI, Anita. A chegada da arte moderna. Manuscrito Fundo Anita Malfatti - Arquivo IEB-USP.

${ }^{102}$ ANDRADE, Mário de. Aspectos da literatura brasileira. 6o ed. Belo Horizonte: Editora Itatiaia, 2002, p. 254.

103 Ibidem, p. 260. 
expuseram na Semana foram representados na coleção: Antônio Paim Vieira e Yan de Almeida Prado com obras, distintas daquelas expostas em 1922; já Antônio Garcia Moya com dois desenhos a carvão, tal qual exibira na Semana ${ }^{104}$; os escultures Vitor Brecheret, com a Cabeça de Cristo e Vitória, e Wilheim Haarberg, Mãe e filho ${ }^{105}$.

Em relação à pintura, Mário de Andrade seguiu a mesma linha, pois colecionou obras dos artistas participantes, que fossem do mesmo período. Assim é o caso de Zina Aita e Ignácio da Costa Ferreira Ferrignac; e, também de Vicente do Rego Monteiro, brasileiro ligado à Escola de Paris, bem como do jovem Emiliano Di Cavalcanti ${ }^{106}$. Há possibilidade de Retrato de moça, de Di Cavalcanti seja uma das obras expostas na Semana. A coroar a Semana estão as três telas de Anita, que Mário conhecia desde 1917.

A coleção desbrava caminhos estéticos com escolhas que definissem o movimento modernista, talvez a repetir o herói Macunaíma, quando resolve "imitar o gigante [Piaimã ou Venceslau de Pietro Pietra]. [...] não queria colecionar pedra, coisa tão difícil de carregar. Além disso, a terra do herói tinha pedras por todos os lados. Não carecia colecioná-las" ${ }^{107}$. Mário de Andrade ao deixar de fora o acadêmico, tão em voga àquele tempo, inclusive seu Torquato Bassi, explicita seu desejo pelo novo e inusitado, como o herói da alcunha "Ai! Que preguiça!...":

Num átimo reuniu milietas delas em todas as falas vivas e até nas línguas grega e latina que estava estudando um bocado. A coleção italiana era completa, com palavras pra todos as horas do dia, todos os dias do ano, todas as circunstâncias da vida e sentimentos humanos. Cada bocagem! Mas a jóia da coleção era uma frase indiana que nem se fala ${ }^{108}$.

A época da Semana de Arte Moderna, muitos artistas atuantes em São Paulo seguiram para Paris, para encontrar a arte moderna tão vislumbrada. A coleção acompanha essa movimentação, ao contrário de seu colecionador que nunca saíra do Brasil, como a se preservar de possíveis influências, a se manter legitimamente brasileiro. Sua coleção fazia para o próprio colecionador a ponte entre o invisível longínquo, como agora o faz para o hodierno a ligação com o colecionador.

A partir de suas amizades na França, juntamente com obras recebidas dos próprios artistas ligados ao Brasil, por intermédio de remessa, Mário de Andrade adquiriu obras de artistas até hoje inexistentes em museus brasileiro, como André Lhote, Marc Chagall e Georges Valmier, além de outros significativos, a citar Pablo Picasso, Juan Gris; e ainda de

\footnotetext{
${ }^{104}$ Mesmo que a identificação das obras seja difícil, é possível que pelo menos um dos carvões seja o elencado no catálogo da Semana de Arte Moderna.

${ }^{105}$ AMARAL, Amaral. Artes plásticas na Semana de 22. São Paulo: Bovespa, 1992, p. 146-162.

106 Sobre Di Cavalcanti, Mário escreveria "pastelista, 'menestral de tons velados' como o apelidei [Mário de Andrade] numa dedicatória esdrúxula". In: ANDRADE, Mário de. Aspectos da literatura brasileira, op. cit., p. 257.

107 CHAGAS, Mário. Museu, literatura e emoção de lidar. CADERNOS DE SOCIOMUSEOLOGIA, 19: 5-34, $2002, \mathrm{p}$. 20.

108 ANDRADE, Mário de. Macunaíma: o herói sem nenhum caráter. 32 ed. Belo Horizonte: Livraria Garnier, 2001, p. 56.
} 
Marc Chagall, Georges Valmier, Fernand Léger, conforme atesta o colecionador "Alegrou-me a idéia de possuir um desenho de Léger. Obrigado" ${ }^{109}$.

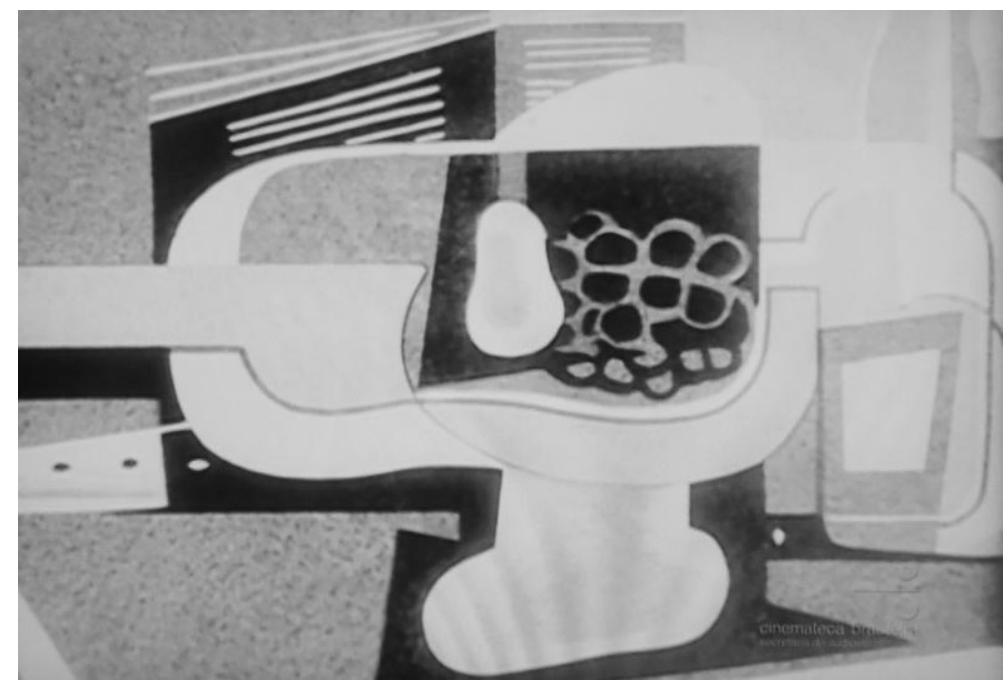

Imagem 4. [Natureza morta] de Juan Gris.

Fonte: A Casa de Mário de Andrade. SANTOS, Ruy (direção). São Paulo: Rangel Filmes Ltda, 1955.

Dos citados acima, faz parte do Acervo IEB: o desenho de Léger, a colagem do cubista de Valmier, e a gravura dedicada a Mário de Andrade, como o "ami inconnu" de Chagall; as demais tiveram outros destinos. Tanto o quadro Futebol de Lhote, quanto Arlequim atribuído a Picasso, estavam exposto ao olhar na casa da Rua Lopes Chaves. O caso da natureza-morta cubista de Juan Gris é curioso, pois, com exceção do filme de $A$ Casa de Mário de Andrade de Ruy SANTOS, não se encontrou outras citações. Em relação a este artista, Mário de Andrade escreve em carta a Anita Malfatti:

Paulo Prado, vi ontem. Trouxe um Juan Gris maravilhoso. 0 Survage não me agradou. $O$ do Oswaldo é muito milhor. Oswaldo trouxe também um Léger admirável: Milhor que o meu - embora o meu seja bom também ${ }^{110}$.

Aventa-se a hipótese que a oferta de venda para a Universidade, partia-se da idéia que - IEB estava ligado aos estudos brasileiros e às Brasilianas. Além disso, as obras estrangeiras poderiam ser mais facilmente vendáveis, com preços maiores do que artistas brasileiros, o que resultaria numa espécie de poupança para a família do escritor.

Em relação a este aspecto prosaico de se formar uma coleção para reserva de=recursos financeiros, é curioso se pensar por que possui poucas pinturas de modernistas economicamente bem situados, com facilidade de venda e próximos, como Lasar Segall e Tarsila do Amaral. De cada um possuía apenas uma tela a óleo, no caso da artista comprara

109 Carta de Mário de Andrade a Sérgio Milliet, de 2 ago. [1923]. In: Paulo Duarte. Mário de Andrade por ele mesmo. SP, Hucitec, 1977, p.292.

${ }^{110}$ Carta de Mário de Andrade a Anita Malfatti, de 3 jan. 1924. In. BATISTA, Marta Rossetti (org.). Mário de Andrade, cartas a Anita Malfatti. Rio de Janeiro: Forense Universitária, 1989, p. 66. 
O mamoeiro logo após a Queda da Bolsa de Nova York; no de Segall recebera em 1932, como presente do artista Retrato de Mário de Andrade realizado em $1927^{111}$.

Também é deste momento o encontro com as gravuras de Lasar Segall, cujo movimento era contrário aos outros artistas, pois chegava ao Brasil, em 1923. Após estudos realizados na Europa. Para além das gravuras, há o interesse pelo expressionismo alemão, cujas temáticas do exilado, do imigrante, são de interesse do colecionador.

É ainda da orgia intelectual, a expansão das fronteiras paulistas, por meio de Manuel Bandeira, quando Mário de Andrade tomara contato com Ismael Nery, Cícero Dias e Oswaldo Goeldi, chega a ser "um 'depositário', a quem os amigos forneciam elementos para seguir o seu tempo" ${ }^{112}$.

Quando entra na fase de construção do modernismo, Mário de Andrade define bem seu interesse pelas questões da "técnica, no sentido em que a estou concebendo e me parece universal, é um fenômeno de relação entre o artista e a matéria que ele move" ${ }^{113}$. Destarte, o colecionador, após a "destruição inicial”, parte para um momento de construção, como a Prof.a Gilda de Mello e Souza coloca:

[Mário de Andrade] É um abridor de picadas ${ }^{114}$, como já o definiram coma acerto, mas sente periodicamente a nostalgia do pouso; por isso, apesar de ter ajudado a renovação artística de seu país (presidindo o estouro dos rios), espera que, vencida a etapa necessária da rebeldia, a arte retome o ritmo sereno, mais favorável à criação (que as águas se acalmem finalmente nas lagoas) ${ }^{115}$.

Após 1930, o movimento modernista caminhou para sua operosidade, quando emergem os "artistas provenientes de estratos sociais de menor renda" ${ }^{116}$, como os Grupo Santa Helena, composto por artesões interessados no métier da pintura, e o Seibi-kai, cuja proposta era coincidente e composta por nipo-brasileiros.

Dos japoneses, a coleção possui apenas desenhos, seja de Yoshiya Takaoka, seja de Tomoo Handa, ou ainda o livro ilustrado por Tsuguharu Foujita, o que demostra certo desinteresse por parte do autor de Paulicéia Desvairada, pois a visualidade e as propostas deste grupo muito se assemelhavam à do Santa Helena. Quando o Japão se alinhara ao Eixo,

111 BATISTA, Marta Rossetti e LIMA, Yone Soares de. Coleção Mário de Andrade. Artes Plásticas. São Paulo: IEB USP, 1984, p. XXVII.

112 Ibidem.

113 ANDRADE, Mário de. O artista e o artesão. Aula inaugural dos cursos de Filosofia e História da Arte, do Instituto de Artes, da Universidade do Distrito Federal em 1938. São Paulo: Centro de Estudos Folclóricos do Gfau, 1955.

${ }^{114}$ Como a imagem do Picador de fumo, de Almeida Júnior, a desbravar os caminhos. Para mais conteúdos ver: LOURENÇO, Maria Cecília França. Revendo Almeida Junior. São Paulo: ECA USP, 1980. (dissertação de mestrado) \& LOURENÇO, Maria Cecília França. Almeida Júnior: o sol no meio da cambio. PALHARES, Taisa (org.). Arte brasileira na Pinacoteca do Estado de São Paulo: do século XIX aos anos 1940. São Paulo: Cosac Naify, 2009 c.

115 SOUZA, Gilda de Mello e. Homenagem a Mário de Andrade: o colecionador e a coleção. In: BATISTA, Marta Rossetti e LIMA, Yone Soares de. Coleção Mário de Andrade. Artes Plásticas. São Paulo: IEB USP, 1984, p. XII.

${ }^{116}$ LOURENÇO, Maria Cecília França. Operários da modernidade. São Paulo: HUCITEC / EDUSP, 1995, p. 17. 
Alemanha e Itália, a situação dos japoneses no Brasil complicou-se, o que levou, inclusive, a alteração das temáticas artísticas, como revela Handa, "a partir de 1937 a prática de saírem juntos para pintar a paisagem sofreu sério revés, em face da legislação vigente, daí a reversão da temática vista das janelas, autorretratos" ${ }^{117}$. Nem mesmo Handa, com quem Mário mantinha relação mais estreita ${ }^{118}$.

Em contraposição à Família Artística Paulista, do qual é um grande incentivador, Mário de Andrade colecionara muitas pinturas. Do grupo inicial, formado no Edifício Santa Helena, Francisco Rebollo Gonsales, Paulo Rossi Osir, Mário Zanini, Aldo Bonadei, Clóvis Graciano, Manuel Martins, Fúlvio Pennacchi, e o escultor Joaquim Figueira, o colecionador não possuía qualquer obra de seu homônimo, Pennacchi e Aldo Bonadei. Em relação a este último, consta do recibo de 20 de novembro de 1937 a aquisição de obra, mas que não está hoje no IEB, nem tampouco da listagem levantada para o Processo de aquisição pela USP.

Ao Grupo Santa Helena se juntara outras artistas, o que se passara a ser Família Artística Paulista, origem proletária, viviam do trabalho em ofícios vários em geral próximos da decoração, com intuito de aprender a pintar bem. Nos fins de semana saíam para pintar os arredores de São Paulo e nas salinhas do Edifício Santa Helena, trabalhavam em conjunto, contratando modelo, desenhando, pintando e discutindo as conquistas técnicas.

Na coleção de Mário de Andrade, destaca-se Cândido Portinari, considerado pelo intelectual como o artista nacional, pois atende ao desejo de arte social e internacionalismo. Além de sua atuação como professor, que a "cada aluno faz um artista diferente e pessoal" ${ }^{119}$, ou contrário de Segall, em sua acepção, que "converte, provavelmente, sem querer, os seus discípulos em seus macaqueadores, e nisto se confina a parte de infecundidade de sua lição".

Um personagem com obra em várias técnicas e projeção, que praticamente fica de fora da coleção de Mário de Andrade é Flávio de Carvalho, ligado ao CAM - Clube dos Artistas Modernos, mais irreverente que a SPAM - Sociedade Pró-Arte Moderna, tivera mais manifestações de vanguarda, experimental e provocativa. Observe-se que o retrato de Carvalho realizado pelo poeta não compõe sua coleção, denotando a proximidade deste com Oswald de Andrade, quando os Andrades já se encontravam afastados, mas especialmente a diferença entre personalidades públicas.

117 LOURENÇO, Maria Cecília França. [Entrevista Tomoo Handa] "Eu sigo meu caminho, seguindo meus olhos e meus sentimentos". Revista do Instituto de Estudos Brasileiros, São Paulo, 39: 91-97, 1994.

${ }^{118}$ Quando Mário estava no Departamento de Cultura, propusera ateliê público para desenho, no qual Tomoo Handa e Waldemar da Costa chegam a dar aulas no Teatro Municipal. In: LOURENÇO, Maria Cecília França. Operários da modernidade. São Paulo: HUCITEC / EDUSP, 1995, p. 32.

${ }^{119}$ ANDRADE, Mário de. Esta Paulista Família. In: MOTTA, Flávio. A Família Artística Paulista. Revista do Instituto de Estudos Brasileiros, São Paulo, 10: 137-175, 1971, p. 155. 
$\mathrm{O}$ s desejos de Mário de Andrade para sua coleção reconhecem o valor de suas coisas da terra com destinação e função públicas. O intuito era distribuí-las por instituições que teriam alguma ligação consigo, principalmente no seu estado, poucos itens para Araraquara e a maior parte para a cidade de São Paulo, que lhe gastou. Felizmente, contudo, o conjunto permanecerá em bloco, graças à aquisição do conjunto pela Universidade de São Paulo, via Instituto de Estudos Brasileiros, em 1968.

É surpreendente que o entrelaçamento dos seus desejos tenha se unido aos rumos do próprio IEB, cujo objetivo objetivo é dedicar-se aos múltiplos aspectos da cultura brasileira, tal qual a enorme gama de interesse do autor de Macunaíma. Depois pela consonância que proporcionaria a recepção e tratamento de outros acervos, com destaque à Coleção Lamego. Soma-se a isso, a possibilidade de configuração, organização e pesquisa do próprio Acervo do Instituto, por meio de suas tipologias documentais: Arquivo, Biblioteca e Coleção de Artes Visuais. De certa forma, foi o coroamento de seu desejo a ida de suas coisas para a Universidade, a qual dá reconhecimento acadêmico ao seu acervo, via o interesse pelos estudos brasileiros.

Esse movimento liga "o invisível ao visível", por meio dos semióforos, da salvaguarda de valores, que celebram o modernismo desde o seu ponto de partida, até a maneira como é enxergado ao longo de suas temporalidades, ora as dadas pelo colecionados, ora internalizadas em sua coleção.

A partir daí, são inúmeros os trabalhos fomentados com este material, com destaque para as pesquisas e exposições com a coleção de artes plásticas, culminando no catálogo desta série, em 1984, pelas pesquisadoras Yone Soares de Lima e Marta Rossetti Batista, cujo acervo também se encontra hoje no mesmo regaço desta casa de cultura.

A formação da coleção ocorria num momento em que a cidade de São Paulo caminhava para se tornar metrópole, mantendo ainda traços de provincianismo. Numa época em que, as coleções particulares faziam às vezes de instituições culturais, ante a exigüidade de museus, se avolumavam os interesses dicotômicos, que iam do privado ao público. Neste contexto, e ao contrário de tantos outros, cujas coleções tiveram finalidade tão diferente, Mário já possuía um espírito público em sua coleção. Cabe lembrar que em uma das estantes de sua casa estava escrito "Não empresto livro. A casa é sua. Venha ler aqui", estendíveis a todas as suas lembranças expostas ao olhar.

Originalmente formada por gravuras estrangeiras em águas-fortes e esculturas em bronze, o interesse do colecionador amplia-se para todo o movimento modernista, para além de seu tempo, coincidindo com a viragem de estilo do poeta simbolista para modernista. Assim, a coleção perpassa os arrebatamentos iniciais do modernismo, com obras emblemáticas da fase heróica e da orgia intelectual, para culminar com na fase de construção, referendando o bem-fazer artístico, de forma a conjugar pesquisa estética, atualização artística e consciência nacional, aspectos fundamentais para transformação da realidade brasileira.

A partir do universo artístico, dentro dessas escolhas muitas obras ficaram de fora. É notável a amplitude que a coleção agregou obras do primeiro tempo modernista, quando avança deixa lacunas. Revela a primazia do movimento modernista, num primeiro movimento deixando de lado obras acadêmicas, quando no fim da vida retoma com a aquisição de obras anteriores à fase heróica. 
2. CASAS E LUGARES QUE FALAM DE MÁRIO 


\section{Na Rua Aurora eu nasci}

Na Rua Aurora eu nasci $\mathrm{Na}$ aurora de minha vida E numa aurora cresci.

No largo do Paissandu Sonhei, foi luta renhida, Fiquei pobre e me vi nu.

Nesta Rua Lopes Chaves Envelheço, e envergonhado Nem sei quem foi Lopes Chaves.

Mamãe! me dá essa lua, Ser esquecido e ignorado Como esses nomes de rua.

Lira Paulista, 1945

Mário de Andrade 


\section{Esses nomes de rua das casas de Mário}

Mário de Andrade, em crônica de 1921, escreveu que "as casas continuaram para [ele] mim a viver como seres vivos, cada qual com o seu rosto, ou sorridente de beleza ou infelicitado pela feiura. Mas isto é falar de[le] mim..." ${ }^{1}$. Ainda em seus dois poemas, Quando eu morrer e Na Rua Aurora eu nasci, o poeta faz referência direta às três casas que morou em São Paulo: a da Rua Aurora, antigo número 320, a do Largo Paissandu, antigo 26; e a da Lopes Chaves, antigo 108, atual 546. Das três, a única que ainda se mantém é a terceira.

A primeira fora no lugar em que nascera e vivera até os seis anos, que era a residência do avô materno e patriarca, Joaquim de Almeida Leite de Moraes, que convidara filha e genro para ficarem sob o mesmo teto. Nela Mário passou pela "aurora da sua vida" ${ }^{2}$, e nela queria "enterrar os pés" 3 .

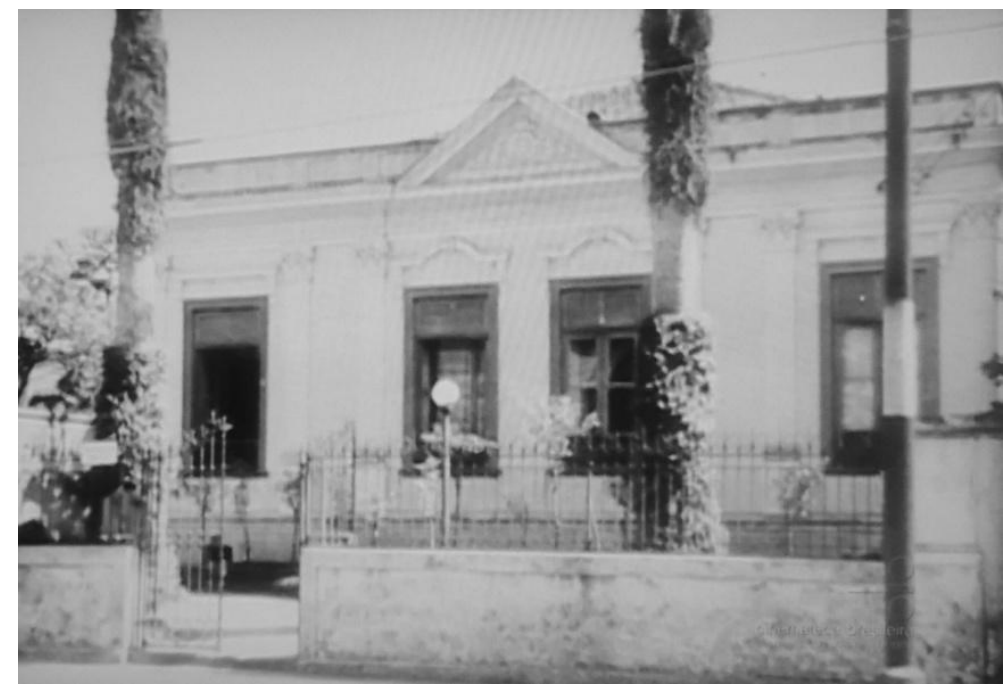

Imagem 5. Casa da Rua Aurora.

Fonte: A Casa de Mário de Andrade. SANTOS, Ruy (direção). São Paulo: Rangel Filmes Ltda, 1955.

Após a morte do avô, mudaram-se todos para o Largo Paissandu. Nesta casa, viviam os pais, Carlos Augusto e Maria Luísa; e os irmãos, por ordem decrescente, de idade, Carlos, Mário, Renato (morto aos 14 anos, em 1913) e Maria de Lourdes. Além, da avó e da tia maternas. Ana Francisca, tia e também madrinha, permaneceria por toda a vida ao lado da irmã ${ }^{4}$ Segundo relato da Prof. a Gilda de Mello Souza, esta cara seria:

Um sobrado de dois andares e porão alto, que testemunhava com eloquência a ascensão econômica de Carlos Augusto de

${ }^{1}$ ANDRADE, Mário de. Ilustração Brasileira, ano 8, no 9, Rio de Janeiro, maio de 1921. In: Cinco crônicas de Mário de Andrade. LOPEZ, Telê Ancona (introd., org. e notas). São Paulo: Editora Senac, 2004, p. 91.

2 Poema "Na Rua Aurora eu nasci", Lira Paulista, 1930. In: ANDRADE, Mário de. De Paulicéia Desvairada a Café (poesias completas). São Paulo: Círculo do Livro, s/d, p. 303.

3 Poema "Quando eu morrer", Lira Paulista, 1930. Ibidem, pp. 304-305.

${ }^{4}$ ANDRADE, Mário de. A imagem de Mário: textos extraídos da obra de Mário de Andrade / [introdução, Telê Porto Ancona Lopez]. Rio de Janeiro: Edições Alumbramento, 1984, p. 22. 
Andrade, pai de Mário. A grande porta de entrada, de madeira, quase na convergência do largo e da Visconde do Rio Branco, dava diretamente na rua. No interior do edifício; à direita de quem entrava, a sala de visitas, cujas janelas se abriam para a Visconde do Rio Branco; à esquerda, a ampla sala de jantar, com seus cinco janelões sobre o largo. Uma escada interna,saindo do fundo da sala, subia até o primeiro andar, desembocando num corredor e, finalmente, na ampla antecâmara para onde davam os quartos. No início, Carlos Augusto instalou seu escritório nesse cômodo e, pelo Natal, era ali que também armava, caprichosamente, o belo presépio da família. Depois de sua morte em 1917, o espaço foi dividido, dando origem ao quarto e ao escritório de Mário. ${ }^{5}$

Tal como descreve a Prof. a Gilda, é provável localizar a casa do Largo do Paissandu, como indicada no mapa da cidade de São Paulo (página 59); todavia, caso esteja indicada corretamente, hoje não há qualquer vestígio desse sobrado no centro de São Paulo. Este espaço participaria da gênese da coleção de Mário, afinal fora para lá que levara sua escultura Cabeça de Cristo, de Victor Brecheret, conforme se viu na Gênese do colecionador; em que, também, fora palco da fomentação de Paulicéia Desvairada

Depois subi para o meu quarto, era noitinha, na intenção de me arranjar, sair, espairecer um bocado, botar uma bomba no centro do mundo. Me lembro que cheguei à sacada, olhando sem ver o meu largo [Paissandu]. Ruídos, luzes, falas abertas subindo dos choferes de aluguel. Eu estava aparentemente calmo, como que indestinado. Não sei o que me deu. Fui até a escrivaninha, abri um caderno, escrevi o título em que jamais pensara, 'Paulicéia Desvairada' ${ }^{6}$.

É possível que a "luta renhida" fossem referência a como este episódio, ou ainda à defesa de Anita Malfatti durante a exposição de 1917. Contudo, fora Oswald de Andrade o primeiro defendera a pintora ${ }^{7}$. O poeta de Paulicéia Desvairada pode ter trazido o início de sua participação no movimento modernista com as lutas que travara, mesmo que individuais questionando-se seus próprios posicionamentos, em que se vira pobre e nu.

De qualquer forma, a estada no Largo Paissandu durou até 1921, momento em que o pai de Mário já morrera e o irmão Carlos se casara. Assim, a mãe a vendeeu para adquirir

${ }^{5}$ SOUZA, Gilda e Antonio Candido de Mello e. A lembrança que guardo de Mário. In: Revista do Instituto de Estudos Brasileiros, São Paulo, 36, 1994, p. 16.

6 ANDRADE, Mário de. O movimento modernista. In: Aspectos da literatura brasileira. 60 ed. Belo Horizonte: Editora Itatiaia, 2002, p. 256.

7 BATISTA, Marta Rossetti. Anita Malfatti no tempo e no espaço: biografia e estudo da obra. São Paulo: Editora 34 / Edusp, 206, p. 221. 
três sobrados ${ }^{8}$ geminados na Barra Funda: um para ela, a filha e a irmã; e os outros para cada um de seus filhos, Carlos e Mário. Segundo o Prof. Antonio Candido, o poeta acordara com a mãe de não receber a herança do pai, desde que morasse com ela, o que the garantiria comida e roupa lavada ${ }^{9}$. Assim, após um período de aluguel, o terceiro sobrado seria vendido ${ }^{10}$.

O último endereço, da Rua Lopes Chaves, é associado com a vida madura de Mário de Andrade, quando vislumbra a morte, e manifesta o desejo de continuar, como em vida, próxima ao seu local de trabalho, de estudo, das suas coisas da terra, enfim o espaço em que exercera sua intelectualidade. Ou ainda, refere-se a sua vivência com frustações, angústias, cujo único futuro imaginado seria o esquecimento, não o dessa figura desconhecida que fora Lopes Chaves, mas acena para o seu próprio.

O presente estudo procura investigar um dado inédito, ou seja, o local escolhido pelo poeta para as obras da coleção de Mário de Andrade em sua casa na Lopes Chaves. Assim, o lugar adotado para as obras pode significar, além de mero gosto, ou estética, as opções críticas e a construção de uma imagem pública, assumindo contornos relevantes para análise, uma vez que é o local em que tudo fora recolhido, protegido e exposto ao olhar, tornando o conjunto semióforos, carregados de significados.
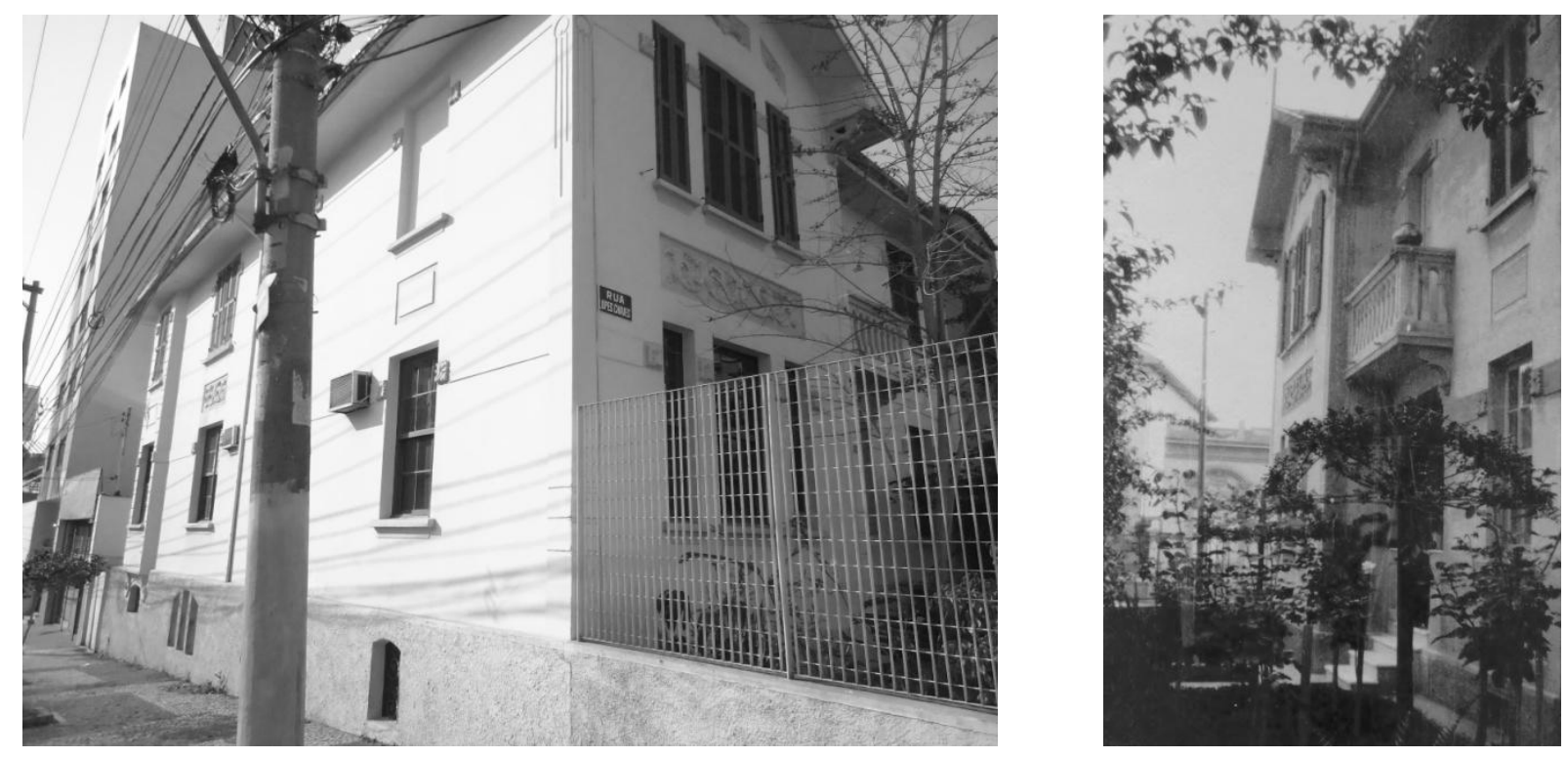

Imagem 6. Esquina da Rua Lopes Chaves, com a Rua Margarida, 2011.

Fonte: B. Dettino.

Imagem 7. Jardim frontal da Casa da Rua Lopes Chaves, 13 out. 1927.

Fonte: Fundo Mário de Andrade - Arquivo do Instituto de Estudos Brasileiros da Universidade de São Paulo.

${ }^{8}$ Este conjunto da Rua Lopes Chaves fora projetado tendo como proprietário o Doutor Oscar Americano de Caldas, que mesmo atuante como dentista fora proprietário de empresa do ramo de construção civil. Não confundi-lo com Oscar Americano de Caldas Filho (1908-1974), que fora dono da construtora CBPO. Juntamente com sua esposa, Maria Luisa Ferraz Americano de Caldas, constituíra uma coleção de pinturas desde o século XVII, mobiliário, prataria, porcelana, tapeçaria e arte sacra do século XVIII. Disponível em <http://www.fundacaooscaramericano.org.br/fundacao20a.html>. Acesso em 06 fev. 2012.

${ }^{9}$ Entrevista Antonio Candido a A., 27 de outubro de 2011.

${ }^{10}$ ANDRADE, Mário de. A imagem de Mário, op. cit., p. 26. 


\section{A Paulicéia de Mário}

A cidade de São Paulo significou sempre uma fascinação para Mário de Andrade, ora amando-a, ora exilando-se dela. Com exceção dos anos no Rio de Janeiro, o escritor de Paulicéia Desvairada sempre residiu na capital paulista, com a qual manteve uma intensa relação, como nos revela o Prof. Valentim Faccioli, fora "um amante dividido, estilhaçado em mil pedaços-fragmentos paulistanos, paulistas, brasileiros, latino-americanos e universais como se quisesse e não quisesse, conjuntamente, fundir-se com ela e separar-se dela [São Paulo]" ${ }^{11}$.

Na virada para o século XX, a capital paulista passa por um processo de transformação: de cidade provinciana para metrópole industrializada. É ponto fundamental nesta guinada a escala populacional, com o acolhimento tanto de imigrantes atraídos pela cafeicultura, quanto de migrantes, sejam eles ex-escravos ou "famílias abastadas ligadas aos negócios da cafeicultura" ${ }^{12}$. Sob a égide da higiene, bairros inteiros foram projetados tais como Campos Elísios, Higienópolis, por exemplo; enquanto, outros se inchavam como nos bairros tipicamente de imigrantes: Brás, Mooca, Cambuci, Bom Retiro, Barra Funda, Pari e Bexiga ${ }^{13}$.
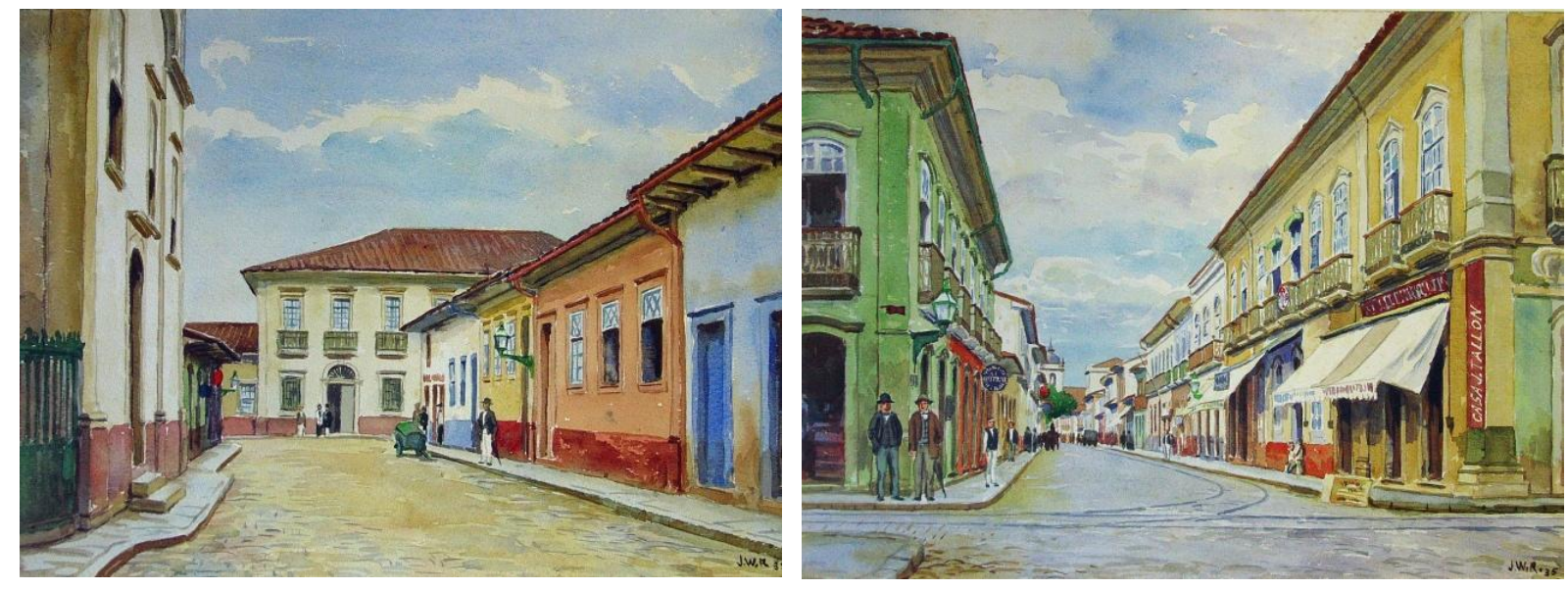

Imagem 8. WASTH RODRIGUES, José. Fim da rua Direita em 1862 (Igreja de Santo Antônio), 1935. guache sobre papel, $22.8 \times 32.0 \mathrm{~cm}$.

Imagem 9. WASTH RODRIGUES, José. Rua Direita, esquina da rua São Bento em 1886, 1935. guache sobre papel, $25.0 \times 33.8 \mathrm{~cm}$.

Fonte: Coleção Mário de Andrade - Coleção de Artes Visuais do Instituto de Estudos Brasileiros da USP.

As aquarelas compradas, em 5 de outubro de $1935^{14}$, revelam aspectos da cidade de São Paulo anteriores às transformações do século XX, possivelmente o interesse de Mário de

${ }^{11}$ FACCIOLI, Valentim. Mário de Andrade e a cidade de São Paulo: aspectos. In: Revista da Biblioteca Mário de Andrade. São Paulo, 50:62-79, 1992, p. 62.

12 GARCEZ MARINS, Paulo César. Habitação e vizinhança: limites da privacidade no surgimento das metrópoles brasileiras. In: História da vida privada no Brasil - República: da Belle Époque à Era do Rádio. NOVAIS, Fernando (org. geral). SEVCENKO, Nicolau (org. do volume). São Paulo: Companhia da Letras, 1998, pp. 172173.

13 Ibidem.

${ }^{14}$ Segundo o recibo de compra, Mário de Andrade pagara a J. W. Rodrigues $790 \$ 000$ (setecentos e noventa mil-réis) por cinco papéis flexíveis: dois desenhos de Ouro Preto (190\$000), um desenho de São Paulo antigo 
Andrade estava em registrar a iconografia paulista. Assim, assinalam-se os aspectos caipira e antigo como uma demarcação de um ponto de partida para esta que será uma grande metrópole, aspiração para o futuro. Esta é uma visão típica da paulistanidade que reconhece seu passado ligado à terra, mas que almeja o mundo essencialmente urbano. Além disso, José Watsh Rodrigues trazia para sua produção artística detalhes de ruas, de igrejas, preocupações típicas de um agente ligado ao órgão de patrimônio, como fora Mário de Andrade.

Para Mário, essas transformações foram narradas em crônicas da década de 1920, durante as alterações pelas quais a cidade tinha suas feições modificadas. O poeta ressalta a diferença entre o Rio de Janeiro, com a primazia dos edifícios públicos, e São Paulo, em que "a edificação particular é incontestavelmente mais perfeita, mais bela e mais adiantada"; para ele, graças à vinda de inúmeros arquitetos estrangeiros, a cidade ganhou feições de exposição internacional ${ }^{15}$. Todavia o mais importante, para aquele momento, seria o novo estilo neocolonial, não sendo o único e lembrando a adesão de Lúcio Costa; para o poeta que nacionalizaria a arquitetura, "estilizando e aproveitando os motivos que nos apresenta o nosso pequeno passado artístico, e formando construções mais adaptadas ao meio" 16 . Dessa forma, o autor de Paulicéia Desvairada sonha que ficaria a cargo de São Paulo a fonte de uma arte brasileira ${ }^{17}$.

Nesta série de crônicas sobre São Paulo, datadas de 1920-21, Mário de Andrade possui uma postura de "orgulho paulista, dissociada da preocupação com o sofrimento humano" 18 . Já em sua palestra $O$ movimento modernista, o autor novamente compara as duas cidades, no intuito de demonstrar as condições paulistas para que se desenrolasse o modernismo, oque vislumbrara na crônica de 1920. Assim, "O Rio era muito mais internacional, como norma de vida exterior. Está claro: porto de mar e capital do país, o Rio possui um internacionalismo ingênito" ${ }^{19}$. Lá, pouca repercussão teria a exposição de Anita Malfatti, e aqui, "criou uma religião, [...] sacudiu uma população, modificou uma vida" ${ }^{20}$, devido a sua "atualidade comercial e sua industrialização em contato mais espiritual e mais técnico com a atualidade do mundo" 21.

Além disso, o autor argumenta que, diferentemente do temor da burguesia carioca em arriscar, o movimento possuía um caráter iminentemente aristocrático tradicional, ligado a terra, que não temia o "jogo arriscado, pelo seu espírito aventureiro ao extremo, pelo seu internacionalismo modernista, pelo seu nacionalismo embrabecido, pela sua gratuidade antipopular, pelo seu dogmatismo prepotente, era uma aristocracia do espírito" ${ }^{22}$.

(100\$000) e duas aquarelas "idem" (500\$000). In: BATISTA, Marta Rossetti e LIMA, Yone Soares de. Coleção Mário de Andrade. Artes Plásticas. São Paulo: IEB USP, 1984, p. XXVIII.

${ }^{15}$ ANDRADE, Mário de. Ilustração Brasileira, ano 8, no 6, Rio de Janeiro, fevereiro de 1921. In: Cinco crônicas de Mário de Andrade. LOPEZ, Telê Ancona (introd., org. e notas). São Paulo: Editora Senac, 2004, p. 95.

${ }^{16}$ Ibidem, p. 97.

${ }^{17}$ Ibidem, p. 98.

${ }^{18}$ LOPEZ, Telê Ancona, ibidem, p. 26.

${ }^{19}$ ANDRADE, Mário de. O movimento modernista, op. cit., p. 258.

${ }^{20}$ Ibidem, pp.258-259.

${ }^{21}$ Ibidem.

${ }^{22}$ Ibidem. 
Em sua coleção de arte, a cidade de São Paulo também se transforma. Há o centro da cidade, ou seria o ponto de viragem para o período destruidor: o Vale do Anhangabaú, desenhados por Zina Aita e Tarsila do Amaral, Retrato de Mário de Andrade e São Paulo respectivamente. Possivelmente, ambos são retratos ficcionais do Vale do Anhangabaú, enquanto Tarsila prioriza elementos típicos do crescimento da cidade: bonde, iluminação pública, os arranha-céus encimados por torres de comunicação, tão usuais na linha da cidade atual, juntamente com uma balaustrada que divide este plano dos elementos naturais já humanizados como as palmeiras e arbustos. Zina coloca o Mário de Andrade interrompendo viaduto, talvez o do Chá, e traçado do Vale do Anhangabaú, do paisagista francês J. A. Bouvard, tendo à direita o Teatro Municipal, referência direta ao palco da Semana de Arte Moderna, e à esquerda a torre da Estação da Luz, cujo relógio está mais para o olho que observa a cidade. Não se pode esquecer que era desta estação que os trens partiam para Araraquara, alusão direta às viagens do autor para o interior paulista.
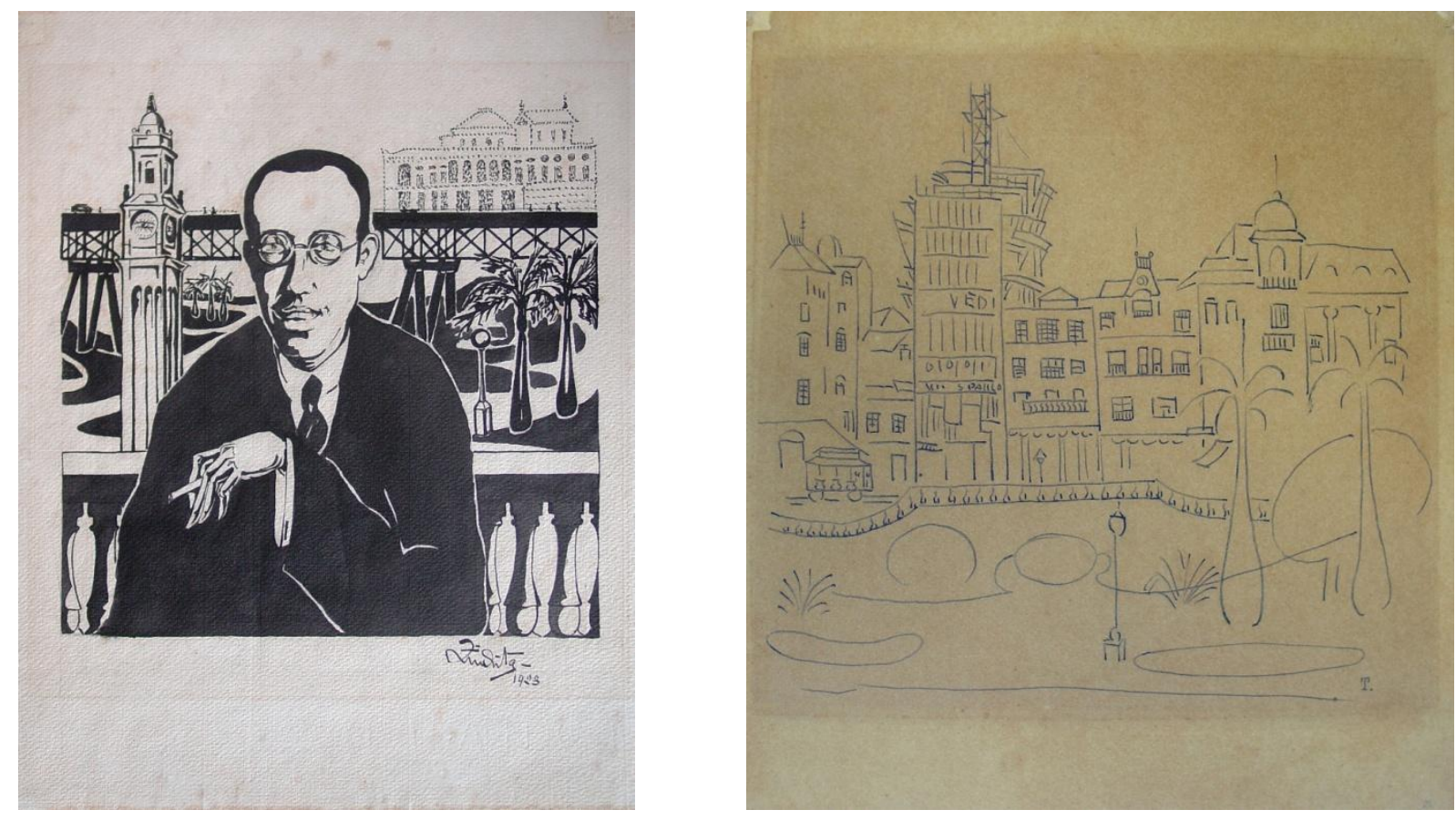

Imagem 10. AITA, Zina. Retrato de Mário de Andrade, 1923. nanquim sobre papel, $28.1 \times 21.9 \mathrm{~cm}$. Imagem 11. AMARAL, Tarsila do. São Paulo, 1924 c. tinta de caneta sobre papel, $26.8 \times 23.8 \mathrm{~cm}$.

Fonte: Coleção Mário de Andrade - Coleção de Artes Visuais do Instituto de Estudos Brasileiros da USP.

As opções de capa para o livro Paulicéia Desvairada vão ao encontro de uma paulistanidade em transformação. A de sua autoria assemelha-se com a visualidade art déco, com letras que lembram galhos e animal onírico. No primeiro plano, encontra-se uma coruja que vigiaria a cidade, ou sinalizaria para o acordar da noite, ou para o funcionar 24 horas da cidade. É interessante notar que os losangos coloridos do Arlequim já estão presentes no colorido da letra "P". Já a proposta de capa realizada por Di Cavalcanti traz o movimento das transformações pelas quais a cidade passava. Ou seria da passagem de Mário de Andrade simbolista para modernista? Por fim, a capa escolhida, projeto de Guilherme de Almeida, remete diretamente à figura de Arlequim, recorrente em Mário de Andrade, como verá mais adiante. 

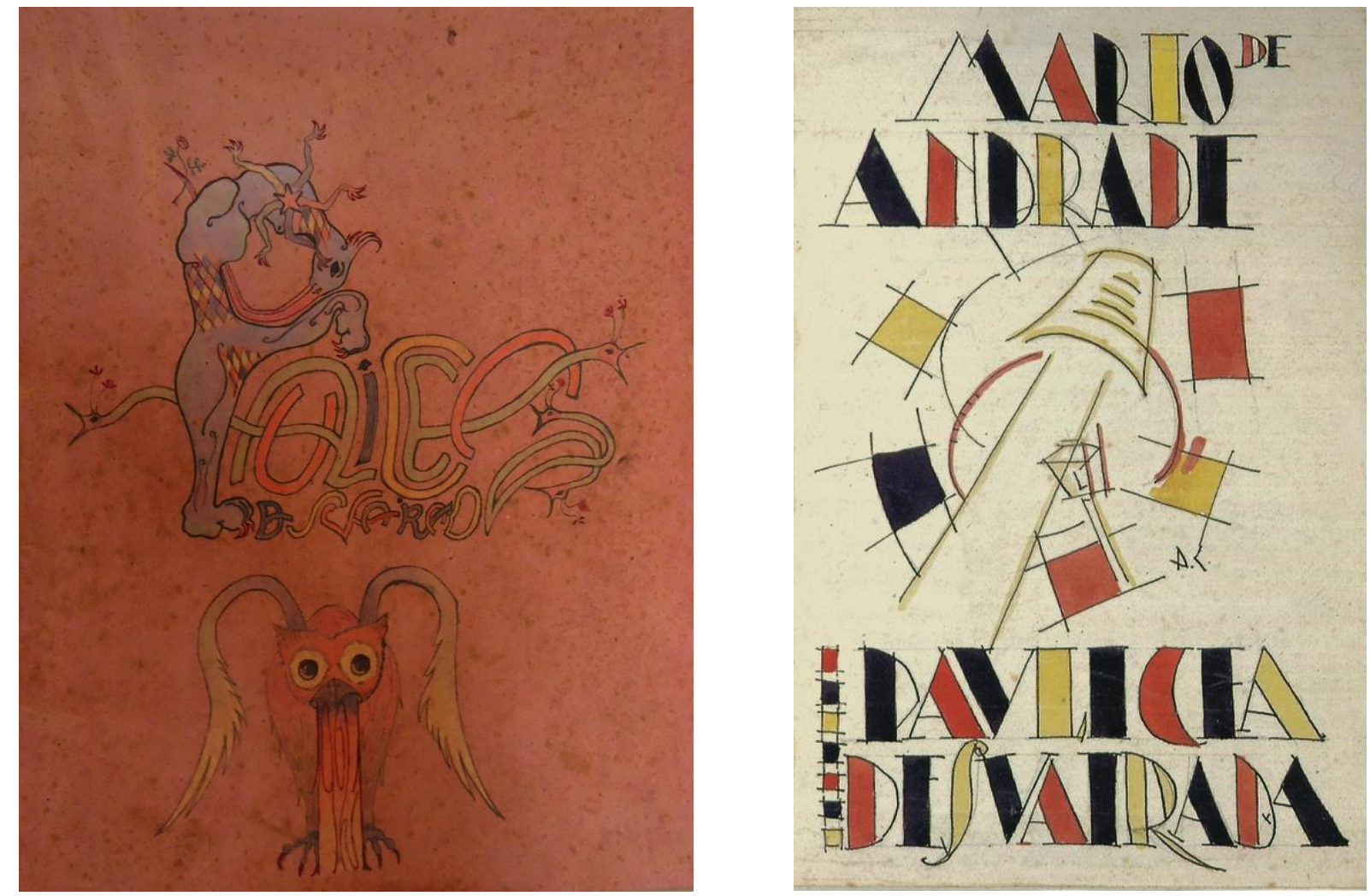

Imagem 12. ANDRADE, Mário de. Paulicéia Desvairada (estudo de capa), s.d. tinta de caneta e lápis de cor sobre cartolina, $31.0 \times 25.0 \mathrm{~cm}$.

Imagem 13. DI CAVALCANTI, Emiliano. Paulicéia Desvairada (projeto para capa), 1921 c. nanquim e guache sobre papel, $25.0 \times 16.2 \mathrm{~cm}$.

Fonte: Coleção Mário de Andrade - Coleção de Artes Visuais do Instituto de Estudos Brasileiros da USP

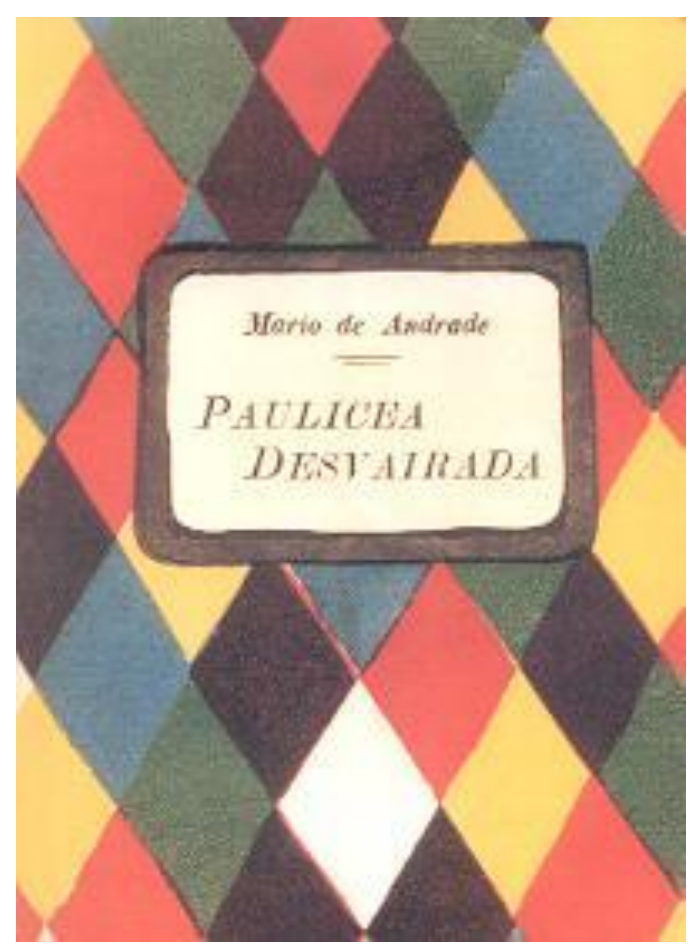

Imagem 14. Capa publicada de Paulicéia Desvairada, desenho de Guilherme de Almeida.

Fonte: Coleção Mário de Andrade - Biblioteca do Instituto de Estudos Brasileiros da USP. 
Outro aspecto da Paulicéia é o pitoresco registrado pela Família Artística Paulista, ao pintar, nos fins de semana, os arredores da cidade, uma alusão ao passado, ou praias do litoral do estado, ao alcance de bolsos menos abonados, como os do colecionador. Estas paisagens pitorescas chamam a atenção pela beleza, pela originalidade tanto do recorte, quanto das soluções pictóricas associadas ao bem-fazer e à operosidade do pintor, como por exemplo, o lado proletário da cidade quando Franco Cenni pinta os fundos das casas dos bairros mais afastados, ou as chacrinhas nos arrabaldes e as praias mais rústicas, como a que Alfredo Volpi apresenta e o poeta agrega em sua coleção.

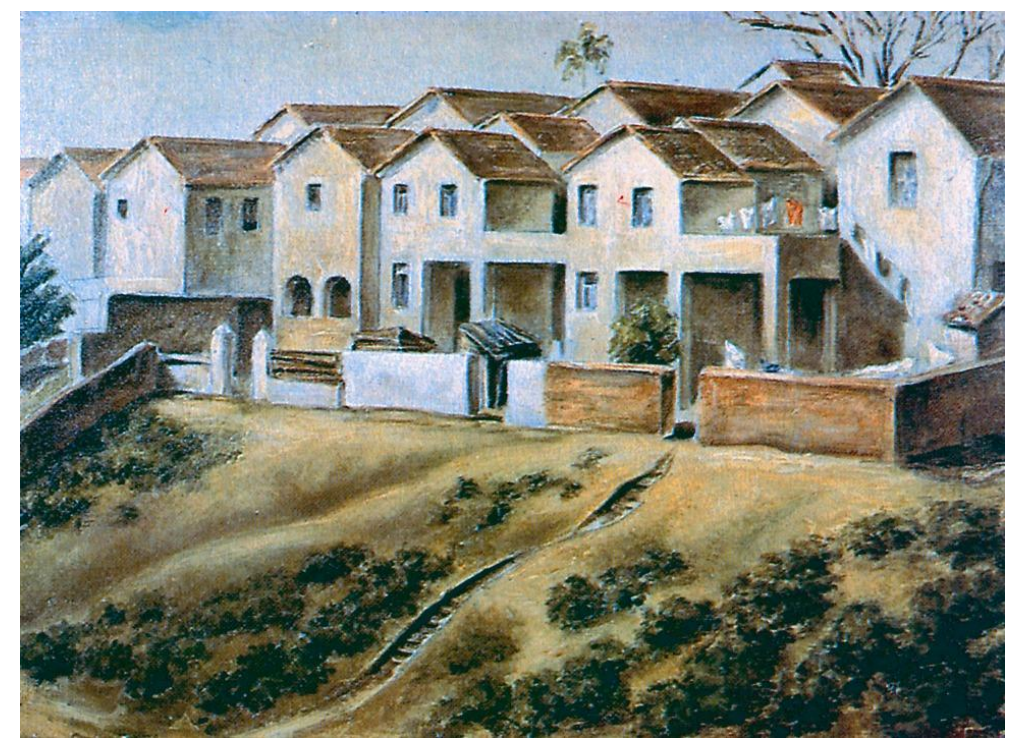

Imagem 15. CENNI, Franco. Casario, 1939. óleo sobre tela, $55.0 \times 75.0 \mathrm{~cm}$.

Fonte: Coleção Mário de Andrade - Coleção de Artes Visuais do Instituto de Estudos Brasileiros da USP

\section{Espacialidade do movimento dos salões}

Para além da sociabilidade, o movimento dos salões de poucos para poucos consagraria a aristocracia paulista como parte constitutiva na consolidação do modernismo brasileiro ${ }^{23}$, nos salões de Paulo Prado, Dona Olívia, Tarsila do Amaral e Mário de Andrade. Abaixo, observa-se a sua geografia paulistana.

O Pavilhão de Arte Moderna de Dona Olívia à Rua Duque de Caxias, deu contorno espacial para que as obras de vanguarda fossem expostas ao olhar. No projeto de decoração, Lasar Segall, que a este tempo era expoente artista atuante em São Paulo e participante do grupo modernista, combinara as "mais belas cores deste mundo, só que tanta cor havia de matar os quadros, pois é o contrário o Léger, a Tarsila ficam sublimes lá dentro" ${ }^{24}$.

\footnotetext{
${ }^{23}$ ANDRADE, Mário de. O movimento modernista, op. cit., p. 261.

${ }^{24}$ CORRESPONDÊNCIA Mário de Andrade \& Manuel Bandeira / Organização, introdução e notas Marcos Antonio de Moraes. São Paulo: EDUSP / IEB USP, 2a ed., 2011, p. 212.
} 


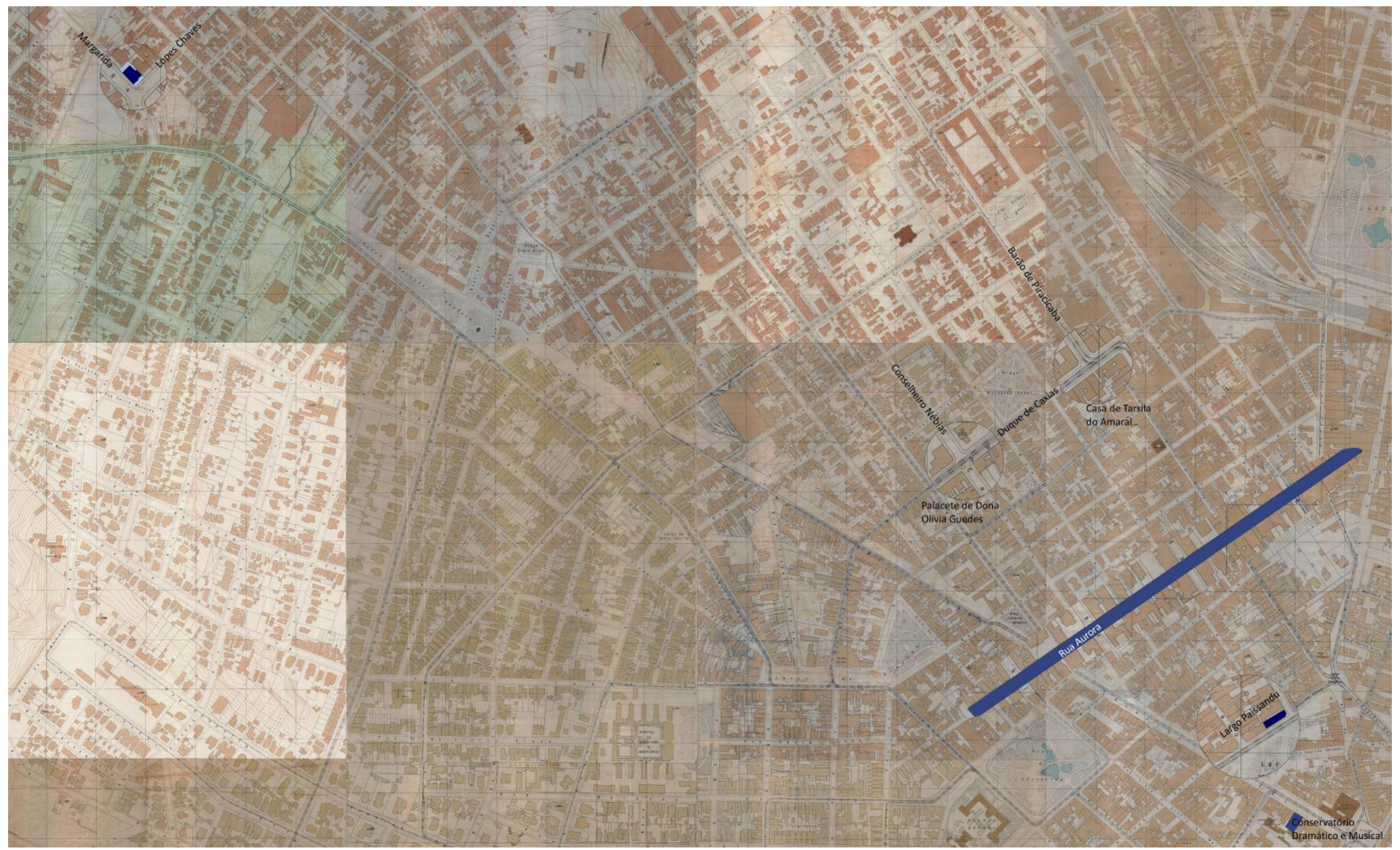

Mapa 1. Mapa topográfico de São Paulo, destaque para as casa de Mário: Rua Aurora; Largo Paissandu e Rua Lopes Chaves. Destaque também para os salões de Dona Olívia, Tarsila do Amaral.

Fonte: MACHADO, Agenor; CORBISIER, Georges; NORONHA, Silvio Cabral. Mapa topográfico do município de São Paulo. São Paulo: Empresa Sara Brasil S/A, 1930. Escala original 1:5.000. 
Desde a entrada deste espaço, o visitante, ou ainda o espectador, que o frequentasse, veria figuras geometrizadas abrem alas para o que virá: o interior do Pavilhão, no qual o forro cubista, domina o espaço trabalhado, principalmente, com as cores primárias - azul, amarelo e vermelho. São incorporadas ao desenho as vigas de sustentação do teto, de tal modo que façam parte da composição a fim de "fundi-la organicamente ao espaço para com ele formar uma unidade", segundo as próprias palavras de Segall ${ }^{1}$.

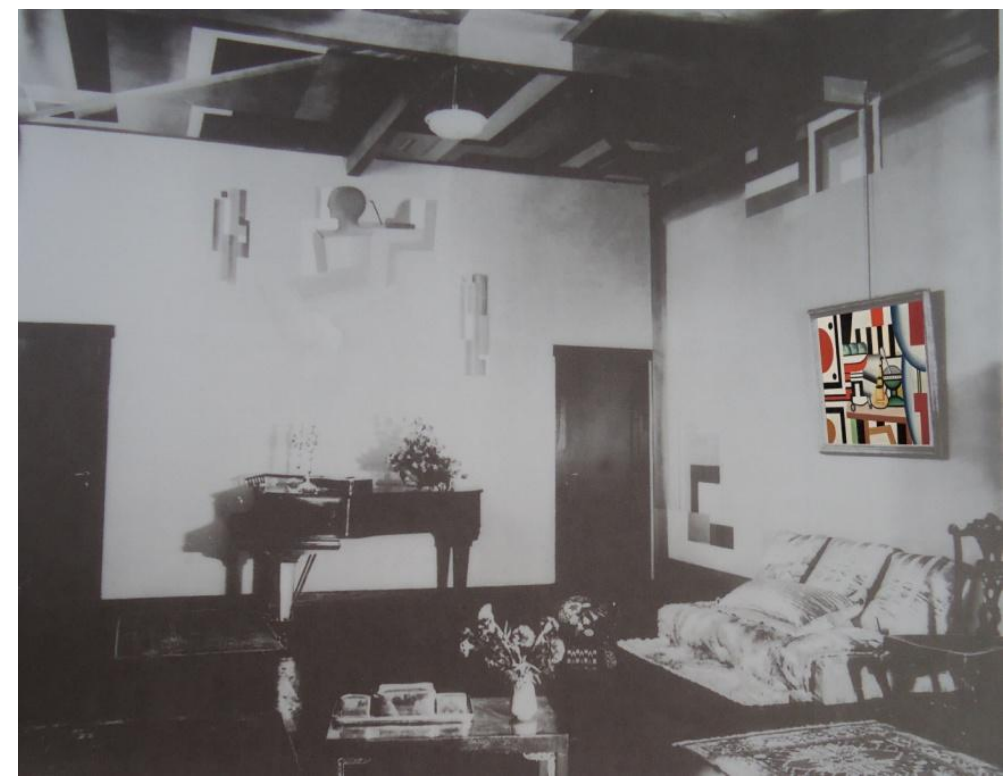

Imagem 16. Pavilhão de Arte Moderna de Dona Olívia Guedes Penteado, 1925.

À direita, o referido quadro de Fernand Léger, Compotier de poires (Compoteira de pêras), óleo sobre tela, 1923 79.0 X $98.0 \mathrm{~cm}$. Hoje integra o acervo do Museu de Arte de São Paulo, MASP, doado por Carolina Penteado da Silva Telles, filha de Dona Olívia.

Fonte: MATTAR, 2002, p. 137.

Já as paredes mantêm os elementos decorativos concentrados no topo do teto e nas bordas das paredes, de tal forma que o centro possa receber o conjunto de obras modernas de Dona Olívia. Além das artes plásticas, esse salão, que se enchia de convidados às terçasfeiras vespertinas, trazia para sua esfera de discussões os demais campos da arte, tais como a literária e a musical. Assim, fazia as vezes de uma sala de exposição, preparada para saraus de leitura e, também, de audição com o piano de meia cauda.

Conforme documentação fotográfica existente, o mobiliário do Pavilhão se modificou ao longo do tempo, com a substituição, por exemplo, de tapetes tradicionais por outros com traçado geométrico, conforme imagens a seguir. Seriam de Regina Gomide Graz? Na mesma linha é a substituição da cortina, do mobiliário. Talvez para constituir, em todos os seus elementos, a mesma linguagem modernizante.

\footnotetext{
${ }^{1}$ Entrevista incorporada a CHATEAUBRIAND, Assis. Na cidade de Pereira Ignácio e de Francisco Matarazzo. In: MATTAR, Denise (org.). No tempo dos modernistas D. Olivia Penteado, a Senhora das Artes. São Paulo: MAB FAAP, 2002, p. 125.
} 

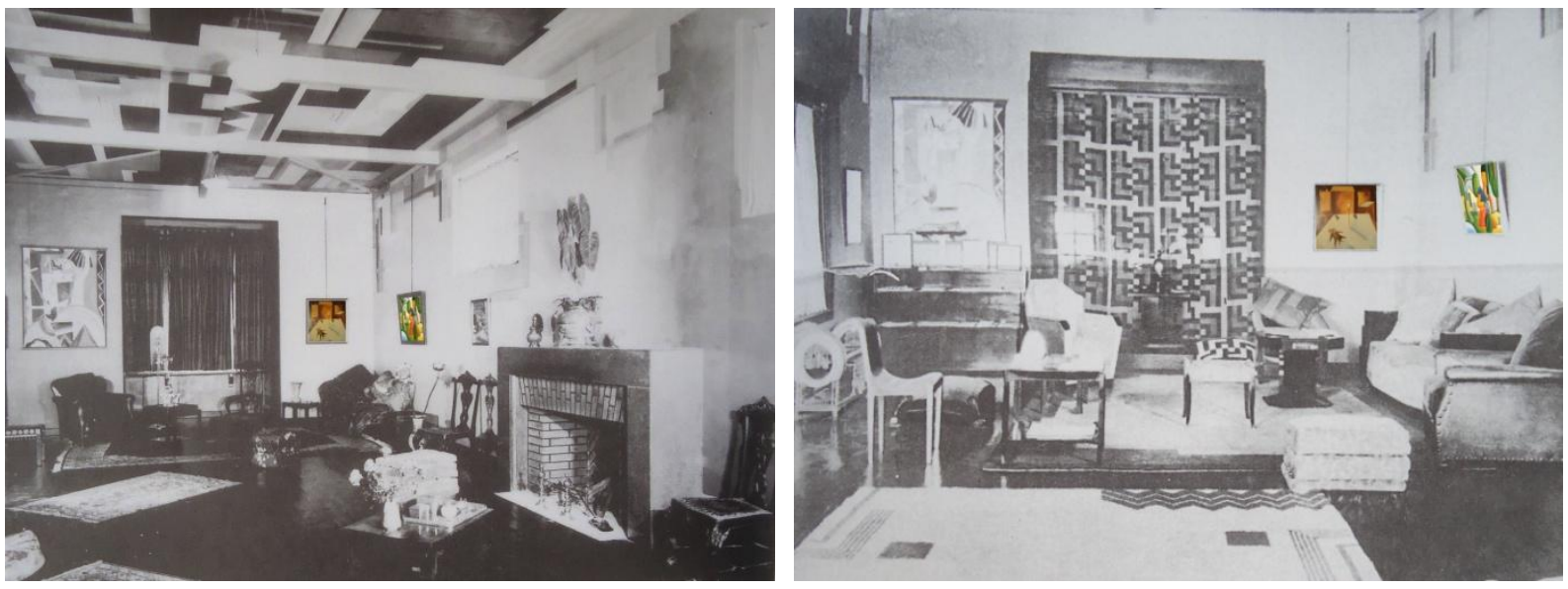

Imagem 17. e 18. Pavilhão de Arte Moderna de Dona Olívia Guedes Penteado, 1925 e posterior.

Fonte: MATTAR, 2002, pp. 136 e 139.

É notório que os quadros se conservaram à altura dos olhos, alinhados por baixo, nos mesmos locais, uma inovação para a época, até na esfera museal, como dados a priori do projeto decorativo. Em oposição ao preenchimento por completo das superfícies verticais, de baixo ao teto, cobrindo toda a parede, conforme se observou na Vila Kyrial de Freitas Valle. Dessa forma, desde o início, o pavilhão adotara o partido da exposição das obras modernas, e Mário de Andrade surpreende-se diante da harmonia que os quadros compõem, ficando sublimes lá dentro.

Essa configuração proporcionava recanto para os modernistas, pois "o grupo se tornava mais coeso, [...] mesmo em reuniões com multidão heterogênea: [...] artistas, políticos, ricaços, cabotinos" ${ }^{2}$. Contudo, as obras modernas estavam restritas tão somente ao espaço do Pavilhão, não faziam parte do interior da casa de Dona Olívia, seja na sala de visitas ou em qualquer outro cômodo, mantendo os pressupostos de casas tradicionais com obras de cunho acadêmico.

A princípio a coleção de Dona Olívia, seguia o chamado gosto "convencional da época: Luís XV em Paris, e bastante eclético em São Paulo" ${ }^{3}$, assim para abrigar sua coleção de quadro modernos e "então lembrou-se de fazer um salão aproveitando uma cocheira velha sem ofício. Ficou maravilha, você não imagina. Decoração inteiramente linear e... volumal do Segall" 4 . Observe-se aqui como a figura de Segall, já se projeta no meio ao elaborar a referida decoração, cenário para os encontros do grupo.

É possível que o interesse de Dona Olívia pelas novas linguagens e parâmetros estéticos da vanguarda, tenha se iniciado no contato com Tarsila do Amaral e Oswald de Andrade. Note-se que a eram praticamente vizinhos, no bairro paulistano dos Campos Elíseos, então disputado pelos que tinham posses; nos anos 1920, viajavam juntos a Paris. Fazia parte da coleção moderna, da referida mecenas, hoje dispersa entre seus familiares,

\footnotetext{
${ }^{2}$ ANDRADE, Mário de. O movimento modernista, op. cit., pp. 262-263.

${ }^{3}$ AMARAL, Aracy. Dona Olivia na Cena Modernista. In: MATTAR, Denise (org.). No tempo dos modernistas $D$. Olivia Penteado, a Senhora das Artes. São Paulo: MAB FAAP, 2002, p. 107.

${ }^{4}$ CORRESPONDÊNCIA Mário de Andrade \& Manuel Bandeira / Organização, introdução e notas Marcos Antonio de Moraes. São Paulo: EDUSP / IEB USP, 2aed., 2011, p. 212.
} 
museus no mundo e colecionadores particulares, obras de "Picasso, Léger, Brancusi, Marie Laurencin, Foujita e André Lhote. Dentre os brasileiros, Tarsila, Segall, Malfatti, Cícero Dias, Antonio Gomide e Di Cavalcanti. Victor Brecheret é o artista mais representativo em sua coleção" ${ }^{5}$.

Dentre os citados, Mário de Andrade incorporara a sua própria coleção, com exceção de Brancusi, todos os nomes citados ${ }^{6}$. Há que se reconhecer a influência do casal Tarsivaldo, principalmente, na ponte entre o alcance do poeta e as obras internacionais. Note-se ainda, que a relação entre espelho e reflexo é de mão dupla, ou seja, tanto a coleção de Dona Olívia exerce o fascínio sobre Mário, quanto este intercede na compra da premiada peça Mise au tombeau ${ }^{7}$ pela aristocrata ${ }^{8}$.

Já o salão de Tarsila do Amaral, diferentemente da "imponência de riqueza e tradição no ambiente, que não era possível nunca evitar um tal ou qual constrangimento", existentes nos salões de Dona Olívia e de Paulo Prado", tivera "uma significação de maior independência, de comodidade" 10 . Todavia, na sala em que ocorreram as reuniões da Alameda Barão de Piracicaba, mesmo com os quadros da vanguarda européia, adquiridos pela artista durante sua estada em Paris, ou de sua própria autoria, a colocação ao olhar segue a premissa de criar um ponto focal no centro da parede. A partir dele, a fruição estética das obras se dá pela composição do conjunto e não isoladamente, tal qual acontecia no Pavilhão da rua Duque de Caxias.

Pode-se considerar que não era um ambiente projetado exclusivamente para o recebimento dessas obras, mesmo assim, é interessante observar o conjunto constitutivo. Envoltas por "almofadões búlgaros, onde gritavam as cores dos mantons de Manilla, riqueza do bric à brac fidalgo dessa esgalgada e linha artista Tarsila do Amaral, o violão de Mário evocava toda a música da raça...!" ${ }^{11}$, cada uma das paredes possui um propósito bem definido: a da esquerda destinada à coleção da artista e a da direita com referências da sua própria produção, incluindo ainda um cartaz, possivelmente, de sua exposição na Galeria Percier, em Paris, de 18 de junho a 2 de julho de 1928.

A separação entre suas obras e as de artistas de vanguardas com os quais Tarsila mantivera proximidade durante sua permanência em Paris ${ }^{12}$, como André Lhote e Fernand

${ }^{5}$ MATTAR, Denise (org.). No tempo dos modernistas D. Olivia Penteado, a Senhora das Artes. São Paulo: MAB FAAP, 2002, p. 20.

${ }^{6}$ Será considerado, como parte da coleção de Mário de Andrade, o livro: FOUJITA, Tsuguji. Légendes japonaises. Recueillies et illustrées par T. Foujita. Préface de Claude Farrère. L'eau--la terre--le ciel--le feu. Paris: Éditions de l'Abeille d'or, 1922 c. (MA094 F766I).

${ }^{7}$ Hoje, esta escultura encontra-se no jazigo da Família Penteado, no cemitério da Consolação, em São Paulo.

${ }^{8}$ Conforme correspondência de Victor Brecheret endereçada a Mário de Andrade, [Paris], [1926], código de referência: MA-C-CPL1486.

${ }^{9}$ Segundo Mário, "o salão da avenida Higienópolis que era o mais selecionado. Tinha por pretexto o almoço dominical [...]. Paulo Prado com seu pessimismo fecundo e o seu realismo, convertia sempre o assunto das livres elucubrações artísticas aos problemas da realidade brasileira". Ibidem, p. 262. A documentação a qual tivemos acesso não permite analisar o salão de Paulo Prado.

${ }^{10}$ ANDRADE, Mário de. O movimento modernista, op. cit., p. 263.

${ }^{11}$ Hélios, "Crônica Social”, Correio Paulistano, 1 set. 1922.

${ }^{12}$ Conforme escreve para Mário de Andrade, em 20 nov. 1922, "Vou ser apresentada a alguns artistas de valor. Estou imbuída de entusiasmo artístico! Chegando a Paris vou trabalhar de verdade". In: Correspondência Mário de Andrade \& Tarsila do Amaral. AMARAL, Aracy (org.). São Paulo: EDUSP/IEB, 2001, p. 51. 
Léger, como, Marc Chagall e Albert Gleizes realçam, por um lado, seu contato com referências européias; por outro, sua própria linguagem que une as vanguardas às raízes brasileiras, na fase pau brasil.

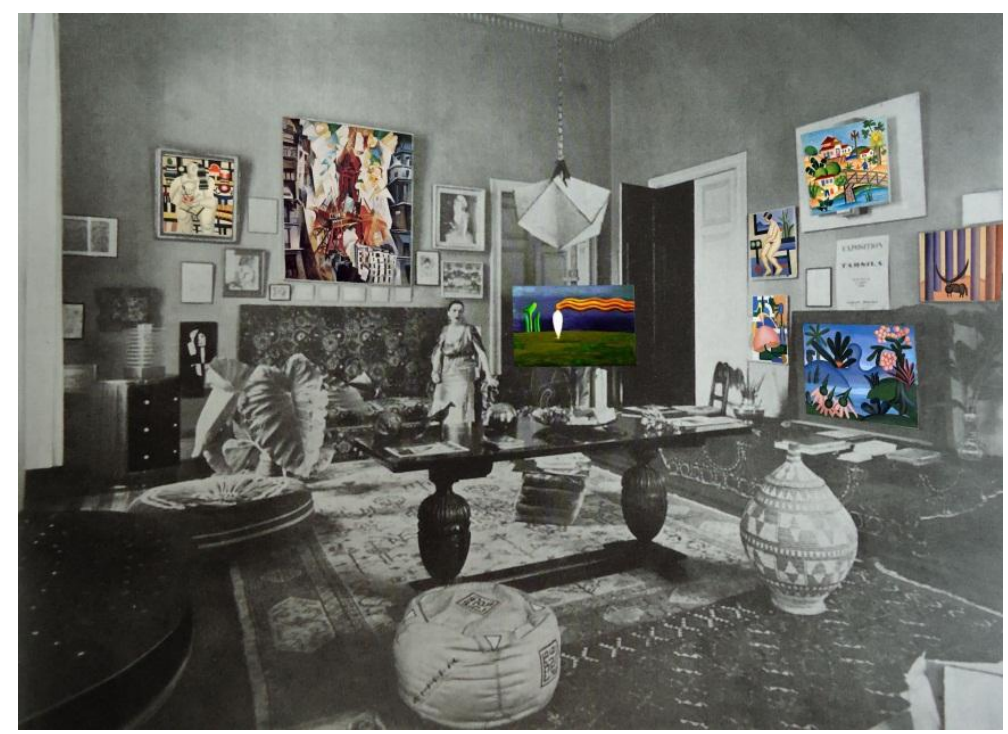

Imagem 19. Salão de Tarsila do Amaral, 1929.

Fonte: AMARAL, Aracy. Tarsila: Sua obra e seu tempo. São Paulo: Ed. 34 / Edusp, 2003, p.329.

No Brasil, a sua primeira exposição individual ocorrera em 1929, primeiro no Rio e depois em São Paulo ${ }^{13}$. Na sua versão paulistana, Tarsila incorporou, de sua coleção particular, "obras reunidas nos últimos anos de Paris", como por exemplo, Pablo Picasso, Fernand Léger, André Lhote, Giorgio de Chirico, Robert Delaunay, Marie Laurencin, Francis Picabia, Juan Miró, Kabatze (russo), Constantin Brancusi ${ }^{14}$. Juntamente com estes nomes, fazia parte de sua coleção: Mendès France, Juan Gris, Albert Gleizes, Amadeo Modigliani, Lasar Segall, Anita Malfatti, Gina Gauthier, Jean-Auguste-Dominique Ingres. Além de Antônio Pedro, Polianski, Ernesto de Fiori, Charchoune e Le Corbusier ${ }^{15}$.

Na imagem do Salão de Tarsila, reconhece-se sobre a mesa, à esquerda, o Prometheus de Brancusi, o quadro à esquerda, La tasse de thé ${ }^{16}$ (A xícara de chá), de Léger e ao centro a Torre Eiffel $^{17}$, também conhecida como Champs de Mars: La Tour Rouge, de Delaunay ${ }^{18}$. Em correspondência de 27 set. 1924, Mário avisa a Tarsila da chegada dos quadros ao Brasil, via Ronald de Carvalho, então funcionário da Secretaria de Estados das Relações Exteriores. É interessante notar que este lote continha tanto a Torre Eiffel, quanto o Futebol, de André

\footnotetext{
${ }^{13}$ AMARAL, Aracy. Tarsila: Sua obra e seu tempo. São Paulo: Ed. 34 / Edusp, 2003, p. 318.

${ }^{14}$ AMARAL, Aracy. Tarsila: Sua obra e seu tempo, op. cit., pp. 328-329.

${ }^{15}$ Ibidem, p. 11 e p. 330.

${ }^{16}$ Em 2010, foi arrematada leilão por USD 7.200.000,00. Disponível em <http://www.christies.com/features/ fernand-leger-la-tasse-de-the-1093-3.aspx>. Acesso em 05 fev. 2012.

${ }^{17}$ Hoje, esta obra faz parte do acervo de The Art Institute of Chicago, possivelmente doada em 1959, integra a Joseph Winterbotham Collection. Disponível em <http://www.artic.edu/aic/collections/artwork/ 9503?search_id=1>. Acesso em 04 fev. 2012.

${ }^{18}$ AMARAL, Aracy, op. cit., p. 329.
} 
Lhote, encomenda do poeta ${ }^{19}$. Quando da queda da bolsa de Nova York, em 1929, Tarsila do Amaral passou por apuros financeiros, levando-a a se desfazer desta coleção.

Infelizmente, muitas dessas obras internacionais, sejam de Dona Olívia ou Tarsila, sejam de Mário de Andrade, retornaram ao circuito de atividades econômicas, e hoje não estejam sob proteção especial. Algumas, depois de sair do Brasil, seguiram por leilões europeus e americanos, encontrando eventualmente instituições museais; outras ainda participam do mercado de arte. De qualquer forma, "é indubitável que o Brasil perdeu, na venda de obras que pertenceram a muitos modernistas, [...] um patrimônio impressionante e impossível de repor hoje em nossas coleções públicas" ${ }^{20}$.

Melhor sorte se teve, pelo menos, com as obras identificadas na foto de autoria da própria artista: acima à esquerda Estudo (Academia no 2), hoje em coleção particular de São Paulo; as duas abaixo $A$ boneca e $O$ lago, na coleção Fadel do Rio de Janeiro; na lateral direita $O$ touro, no acervo do Museu de Arte Moderna da Bahia. Coroando a imagem, $O$ mamoeiro, que Mário de Andrade comprara em 1930, em face da situação econômica complicada de Tarsila. Hoje compõem uma das obras mais representativas do Instituto de Estudos Brasileiros.

${ }^{19}$ CORRESPONDÊNCIA Mário de Andrade \& Tarsila do Amaral. AMARAL, Aracy (org.). São Paulo: EDUSP/IEB, 2001, pp. 85-86.

${ }^{20}$ AMARAL, Aracy, op. cit., p. 12. 


\section{Nesta rua Lopes Chaves, a coleção de Mário}

A importância da casa na Barra Funda se configura desde os salões, juntamente com os de Dona Olívia, Tarsila e Paulo Prado, que constam em $O$ movimento modernista. Os contornos que possuía neste período não equivale ao que o colecionador deixou em 1945, contudo, Mário de Andrade já a via, "sob o ponto de vista intelectual, como o mais útil dos salões, si é que se podia chamar salão àquilo. [...] A arte moderna era assunto obrigatório. As discussões alcançavam transes agudos, o calor era tamanho que um ou outro sentava nas janelas (não havia assento pra todos) [...]" $]^{\prime 21}$.

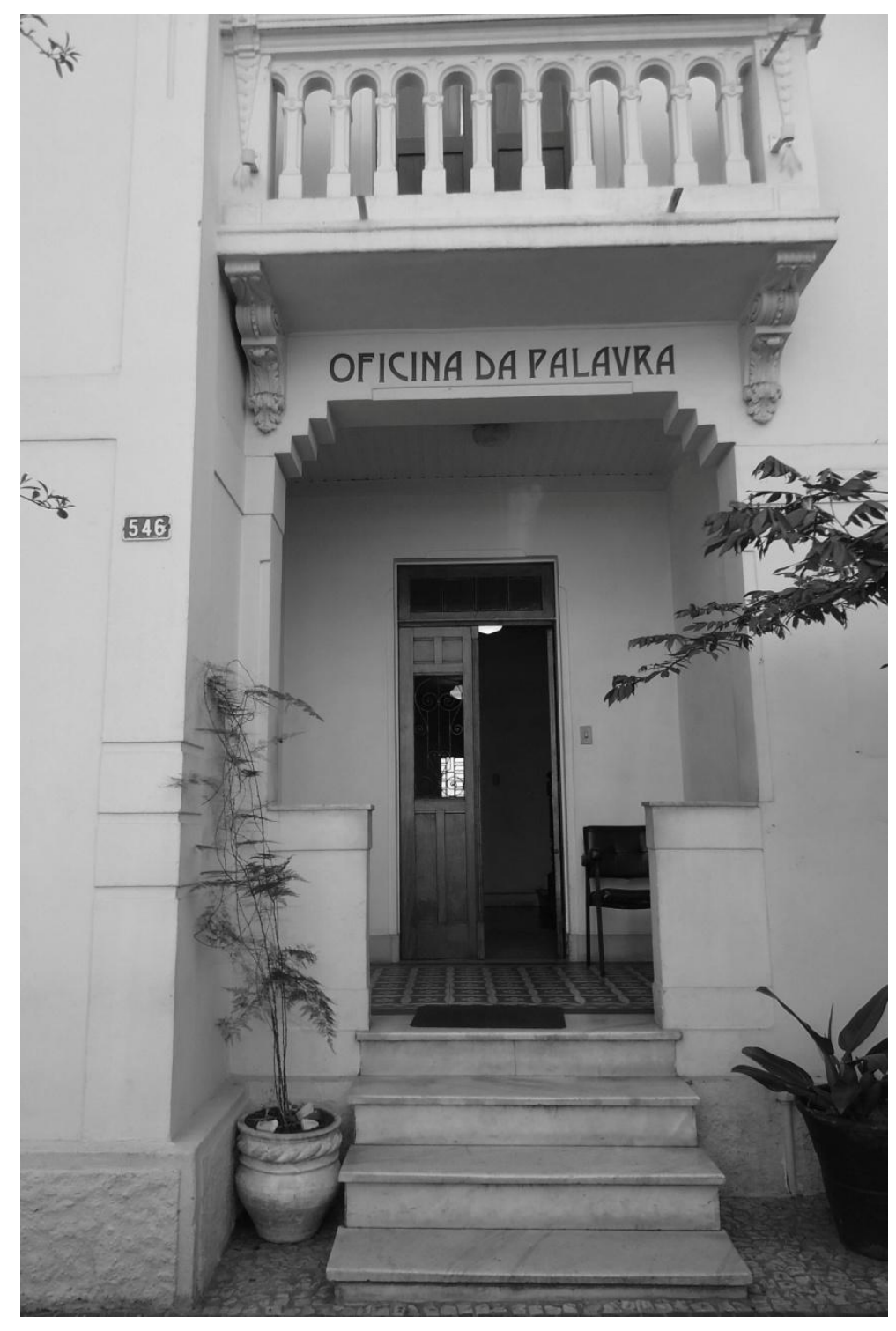

Imagem 20. Entrada da Lopes Chaves, 2011.

Fonte: B. Dettino.

${ }^{21}$ ANDRADE, Mário de. O movimento modernista, op. cit., p. 261. 
A casa da Lopes Chaves geminada com outras duas possibilitou que o núcleo familiar de Mário de Andrade se mantivesse próximo. O programa da casa atendia às demandas de separação das diversas funções da casa: áreas públicas, privadas e intermediárias, desde o exterior ao interior da residência. O distanciamento da fachada em relação à calçada permitia que as áreas internas se mantivessem isoladas do movimento da rua. Assim como o porão elevava as janelas a um patamar acima do alcance do transeunte.

Dentro da casa, as áreas públicas destinadas para as funções sociais, sala de visitas e de jantar, são permeadas por áreas intermediárias de ligação, tais como corredores e hall. A solução do sobrado contribui para isso, já que os quartos, áreas privadas por excelência, ficam em planos diversos dos demais.

Não se pode tirar do foco, de que a residência era a casa da família, na qual moravam sua mãe Mariquinha e sua tia-madrinha Nhanhã. As duas eram presenças constantes, já sua irmã Lourdes continuou até seu casamento, com Eduardo Ribeiro dos Santos Camargo, em 15 de janeiro de $1936^{22}$, momento em que também deixou de ser a "secretária exemplar. Fichava livros, batia à maquina artigos, cuidava do ritual elaborado da desinfecção dos volumes" ${ }^{23}$.

O domicílio ainda recebeu Gilda de Moraes Rocha e sua irmã Maria, as quais se transferiram de Araraquara para a casa de "vovó laiá" ${ }^{24}$, com finalidade de cursarem o Colégio Stafford $^{25}$. Mário de Andrade primo-irmão do pai da Prof.a Gilda de Mello Souza, cuja estada na Lopes Chaves se dera durante o período de 1931 a 1943, quando se casara com o Prof. Antonio Candido. Além dos moradores, ainda participavam da rotina da casa: Sebastiana de Campos e Silva, Tana, cozinheira desde 1925 e, a partir de 1936, de José Bento de Faria Ferraz, secretário de Mário de Andrade.

Durante o período em que a família ali morou, a configuração espacial do andar térreo era: sala de visitas, sala de jantar, escritório convertido em sala de aula para piano, sala de estudo, quarto de costura, cozinha, lavabo e áreas de circulação, seja hall ou escada. Já no segundo andar, 6 quartos e um banheiro. O porão acessível distanciava os cômodos das casas da circulação da rua e, segundo Antonio Candido, Mário de Andrade utilizava-o como depósito de livros de sua própria autoria, cuja publicação fora financiada as suas próprias expensas $^{26}$. Assim, parte do que não circulara, encontrava destino neste espaço, provavelmente com outros livros. De acordo com o inventário realizado pelo IEB, no momento da incorporação das coisas da terra pela USP, a sala correspondente à letra $\mathrm{G}^{27}$,

${ }^{22}$ Correspondência de Maria de Lourdes de Andrade Camargo a Mário de Andrade. São Paulo, 03 set. 1938 , pertencente ao Fundo Mário de Andrade, código de referência: MA-C-CPL1568.

${ }^{23}$ SOUZA, Gilda e Antonio Candido de Mello e. A lembrança que guardo de Mário. In: Revista do Instituto de Estudos Brasileiros, São Paulo, 36, 1994, p. 18.

${ }^{24}$ A mãe de Mário, Dona Mariquinha, era irmã da mãe do pai da Prof.a. Gilda. In: Revista do Instituto de Estudos Brasileiros, São Paulo, 36, 1994, p. 11.

${ }^{25}$ Localizava-se na Alameda Cleveland, bairro de Campos Elíseos, casa que pertencera à família Henrique Santos Dumont. Hoje funciona o hoje o Museu da Energia de São Paulo. Disponível em <http://www.energiaesaneamento.org.br/redemuseuenergia/edificio.php?id=1>. Acesso em 05 fev. 2012.

${ }^{26}$ Depoimento de Antonio Candido, a A. em 27 out. 2011.

27 ANDRADE, Mário de. Entrevistas e depoimentos. Telê Porto Ancona Lopez (org.). São Paulo: T. A. Queiroz, 1983, p. 98 (nota de pesquisa). 
possuía "3 estantes, 1 estante pequena e 1 estante não classificada, contendo revistas, jornais, livros" 28.

O Prof. Antonio Candido desenhou a planta da Lopes Chaves, tanto o térreo como o primeiro andar, enquanto trazia à lembrança recordações do tempo em que a frequentou, a partir de 1940. Em linhas gerais, o esboço é tal e qual a casa, nota-se de diferente apenas a marcação da entrada e o quarto contíguo ao da mãe de Mário. Pelo fato da entrada deste cômodo ser por outro, implicava que sua futura esposa, naquele momento ainda Gilda de Moraes Rocha, deveria chegar cedo, para não incomodar Dona Mariquinha. Além disso, o notável Professor associa a sala de música do térreo com o harmônio, indicado com "SH", contudo o instrumento, pelos demais registros, estava no estúdio de Mário de Andrade, conforme se verá adiante.
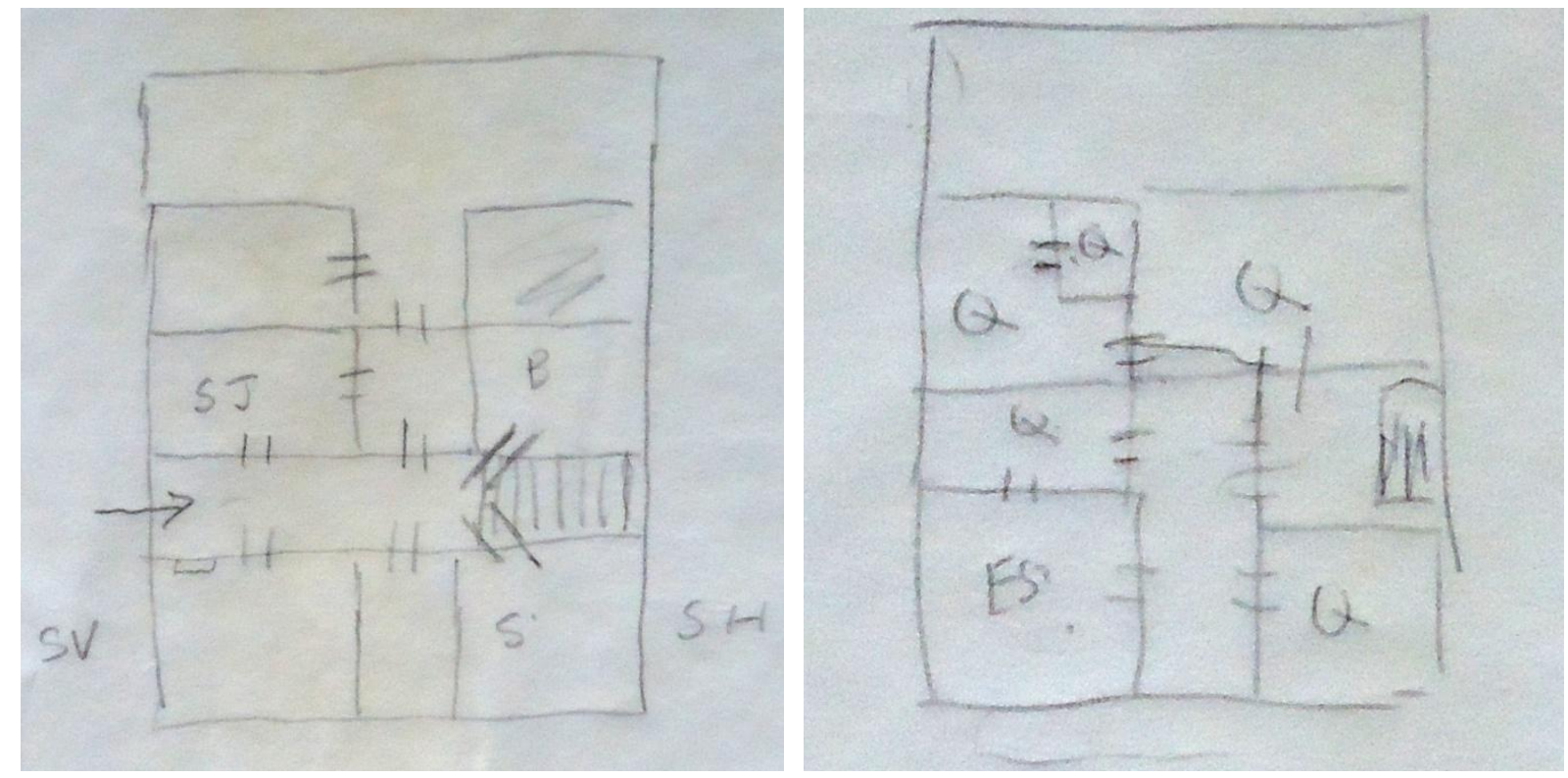

Planta 1 e 2. Desenho do térreo e do primeiro andar, Rua Lopes Chaves, por Antonio Candido. SV - sala de visitas, SJ - sala de jantar, SH - sala do harmônio, B - biblioteca, ES - estúdio, Q - quarto.

Fonte: Entrevista Antonio Candido a A., 27 de outubro de 2011.

Os registros da Lopes Chaves são variados: fotografias do próprio poeta em seu escritório, entrevistas nas quais a casa ou parte dela é descrita, reportagens com homenagens póstumas a Mário, e, ainda dois vídeos ${ }^{29}$, um de 1955, documentário de Ruy Santos, e outro de 1968, de Geraldo Sarno e Thomaz Farkas.

É possível que este último tenha se dado no momento anterior a vinda das coisas da terra de Mário de Andrade para o Instituto de Estudos Brasileiros, como forma de gravar, pela última vez, a sua ambientação. Em concomitância ao recebimento deste material, o Instituto de Estudos Brasileiros criava campos de atuação, tal como o de produção de filmes, o qual se formalizou pela iniciativa de um grupo de cineastas, entre eles o Prof. Paulo Emilio

\footnotetext{
${ }^{28}$ Para maiores dados, consultar Processo USP 1967.1.107.31.8, pp. 30-36.

${ }^{29}$ Agradeço ao Prof. Marcos Antonio de Moraes a indicação destes filmes durante o Exame de Qualificação, realizado em 30 de ago. 2011.
} 
Salles Gomes ${ }^{30}$. Desta parceria, Thomaz Farkas e Geraldo Sarno realizam o documentário: Casa Mário de Andrade ${ }^{31}$.

Este filme inicia-se com cenas externas da casa, como de um visitante que ao ser convidado se aproxima passo a passo da entrada até adentrar o vestíbulo. A edição segue pelo hall do piso superior e entra no dormitório de Mário. Para logo em seguida, voltar à saleta de piano ${ }^{32}$ no térreo, com registros bem precisos da pintura de parede que rodeia a linha superior do teto, da distribuição do mobiliário, que inclui um piano-armário com candelabros fixos, das estantes forradas de livros através do vidro de suas portas, e, principalmente, da disposição de objetos de sua coleção.

Em seguida, o espectador passa rapidamente pela sala de jantar no térreo, para deterse na sala de visita com piano meia-cauda e, principalmente, nas estantes em que se exibem santos católicos, ex-votos, trançados e cerâmicas indígenas originários da Amazônia, objetos religiosos afro-brasileiros, utensílios de ornamentação, brinquedos, tudo reunido a formar um grande mosaico expositivo para os convidados da casa. Tendo em vista o provável interesse dos cineastas em registrar a cultura popular ${ }^{33}$, em especial, a do nordeste, é provável que tenham se detido nesta variada disposição.

Para completar a visita, as cenas se voltam para o estúdio no primeiro andar, com destaque para sua exposição particular de obras de arte plásticas, juntamente com peças que caracterizam as manifestações culturais brasileiras. Neste cômodo, ressaltaram-se os elementos próprios do ofício de escritor, tal como mesa de trabalho forrada com publicações de interesse do intelectual e a máquina de escrevera, carinhosamente chamada de Manuela, em homenagem a seu grande amigo Manuel Bandeira, com quem manteve um conjunto significativo de troca de correspondências, estudado por Marcos Antonio de Moraes.

O caminho para o encerramento do filme se dá pelo hall da escada, em que estão, juntamente com a vastidão de seu fichário, alguns quadros e pastas, que possivelmente acomodavam os papéis flexíveis de sua coleção. Sem nenhuma sonorização, o percurso refaz as trezentas, trezentas e cinquenta facetas da casa, a fazer sinédoque da vida de Mário de Andrade.

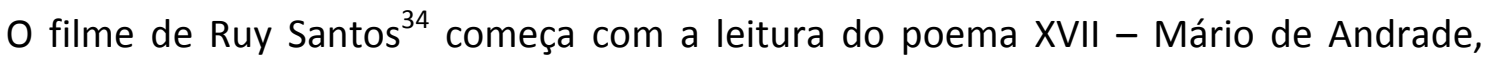
intransigente pacifista, que faz parte do Losango Cáqui, associada a cenas da cidade de São

30 D'ALMEIDA, Alfredo Dias. Caravana Farkas (1968/1970): a cultura popular (re)interpretada pelo filme documentário - um estudo de folkmídia. São Paulo: Universidade Metodista de São Paulo, 2003, pp. 87-88. (dissertação de mestrado)

31 Casa de Mário de Andrade. SARNO, Geraldo (direção). FARKAS, Thomaz (fotografia). São Paulo: Departamento de Produção de Filmes Documentários do Instituto de Estudos Brasileiros da Universidade de São Paulo, 1968. Cópia deste filme pertence ao Serviço de Arquivo do Instituto de Estudos Brasileiros da USP.

32 Em carta a Zé Bento, Mário de Andrade nomeia este cômodo desta maneira: saleta de pianinho. Correspondência de Mário de Andrade a José Bento Ferraz, Rio de Janeiro, 10 de agosto de 1938. Fundo José Bento Ferraz - Arquivo IEB USP.

${ }^{33} \mathrm{O}$ intuito deste grupo era levar a cabo o cinema barato realizado com "uma câmera na mão e uma idéia na cabeça", que retratassem a realidade brasileira, indo ao encontro da arte popular colecionada por Mário de Andrade.

${ }^{34}$ A CASA de Mário de Andrade. SANTOS, Ruy (direção); SOUZA, Gilda de Mello (argumento e roteiro). São Paulo: Rangel Filmes Ltda, 1955. 35 mm, bp, $21 \mathrm{~min}, 561 \mathrm{~m}, 24$ q. SIWACZENKO, Konstantyn (som); GUARNIERI, Camargo (música Sinfonia no 3); FORSTER, Walter (narração). Cópia deste filme pertence ao 
Paulo: arranha-céus e fábricas, carros e multidão, chaminés e asfalto, tudo revela as mudanças que transformou a provinciana cidade em um grande centro urbano. Enquanto a narração suaviza a dureza da cidade, com o distanciamento do centro à periferia por ruas arborizadas até chegar ao recanto da Lopes Chaves.

O anfitrião, já ausente, abre o portão e a porta convidando o espectador a entrar neste retiro intelectualizado absorto na vasta cultura brasileira. A entrada pelo vestíbulo encaminha o visitante para a escada, em que está a tela Futebol de André Lhote, que chega ao hall do primeiro andar. Neste ponto, são destacadas as estantes lotadas de livros e também o móvel que acondiciona o fichário de Mário de Andrade.

São tomadas que registram a recepção de Mário de Andrade para suas visitas: recebêlas no vestíbulo e levá-las diretamente ao seu estúdio, no primeiro andar. Após uma vista panorâmica do estúdio, o olhar se fixa nas seguintes telas: $A$ estudante russa, $O$ homem amarelo e $O$ japonês, obras de Anita Malfatti que participaram da emblemática exposição de 1917. A câmera afasta-se retornando ao plano do estúdio, como a filmar detalhes da vida de escritor: máquina de escrever, manuscritos, caneta, tinteiro, livros de sua autoria já publicados, emendando com manifestações de seu interesse como o catimbó, prática tipicamente mestiça que une magia europeia a rituais indígenas de pajelança, agregados ao catolicismo, além de influências africanas. Manifestações populares convivem em harmonia com as eruditas, a formar a nacionalidade brasileira, multifacetada tal como o colecionador, ora retratado por Portinari, ora por Segall.

A partir daí, o filme dedica-se a biografia de Mário mostrando a casa da Rua Aurora; a conclusão dos estudos musicais no Conservatório Dramático e Musical; sua ligação com o grupo modernista: Oswald de Andrade, Manuel Bandeira, Graça Aranha, Paulo Prado; sua atuação no Departamento de Cultura, em especial os parques infantis e o Congresso da Língua Nacional Cantada; e, por fim seu exílio no Rio de Janeiro.

Quando, não só o professor de música, como também a cena retorna para São Paulo, para sua sala de aula de piano, em que suas coisas o apaziguam. Assim como, a sala de visita da família com o piano de meia-cauda. Ou suas águas-fortes: Raoul Dufy, Marc Chagall, Klaus Ritcher, Fernand Léger, Juan Gris, Johann Moritz Rugendas, Jean-Baptiste Debret, incluindo aqui alguns seus livros ditos de "luxo": Siegfried et Le limousin de Jean Giraudoux e Bouddha vivant de Paul Morand, ambos com ilustrações de Alexeieff. Ainda, a coleção de santos católicos juntamente com arte religiosa afro-brasileira. Para finalizar, com uma última passagem pelo seu Picasso, mesmo que atribuído, pelas teclas do piano e por seu retrato fundido em bronze por Wilhelm Zadig.

Este documentário participara da III Bienal do Museu de Arte Moderna de São Paulo, cuja temática era 10 anos de filmes sobre arte e Paulo Emília Salle Gomes, o conservador da filmoteca do Museu de Arte Moderna de São Paulo. Segundo o catálogo desta mostra, seu propósito principal é demonstrar o aprofundamento e a amplificação possíveis, proporcionadas pelos filmes sobre arte. Gerando a sensibilização de "autoridades culturais, 
governamentais e privadas, a tomada de consciência da possibilidade de se criar um Museu Imaginário de imagens luminosas" ${ }^{35}$. Na sinopse do documentário, consta sua intenção:

[...] prestar uma homenagem [...] através das coisas que o cercaram, das imagens religiosas, dos quadros, dos livros, das gravuras, das músicas, enfim do admirável patrimônio artístico que conseguiu reunir carinhosamente pela vida afora, que podemos refazer o roteiro intelectual de sua personalidade inquieta e multiforme ${ }^{36}$.

Por meio de variadas notas publicadas em jornais brasileiros tais como, Shopping News (18 set. 1955), Folha da Noite (19 set. 1955), O Estado de S. Paulo (22 set. 1955), Folha da Tarde (24 set. 1955), Diário da Noite (24 set. 1955), e, o italiano Fanfulla (22 set. 1955), é possível averiguar que $A$ Casa de Mário de Andrade foi o primeiro filme projetado daquela Bienal. A Folha da Tarde ainda acrescenta que o tema conseguiu "dar aos detalhes mais insignificantes que enquadrou, a presença espiritual do homem que ali residiu, que ali trabalhou e ali criou sua obra admirável" ${ }^{37}$.

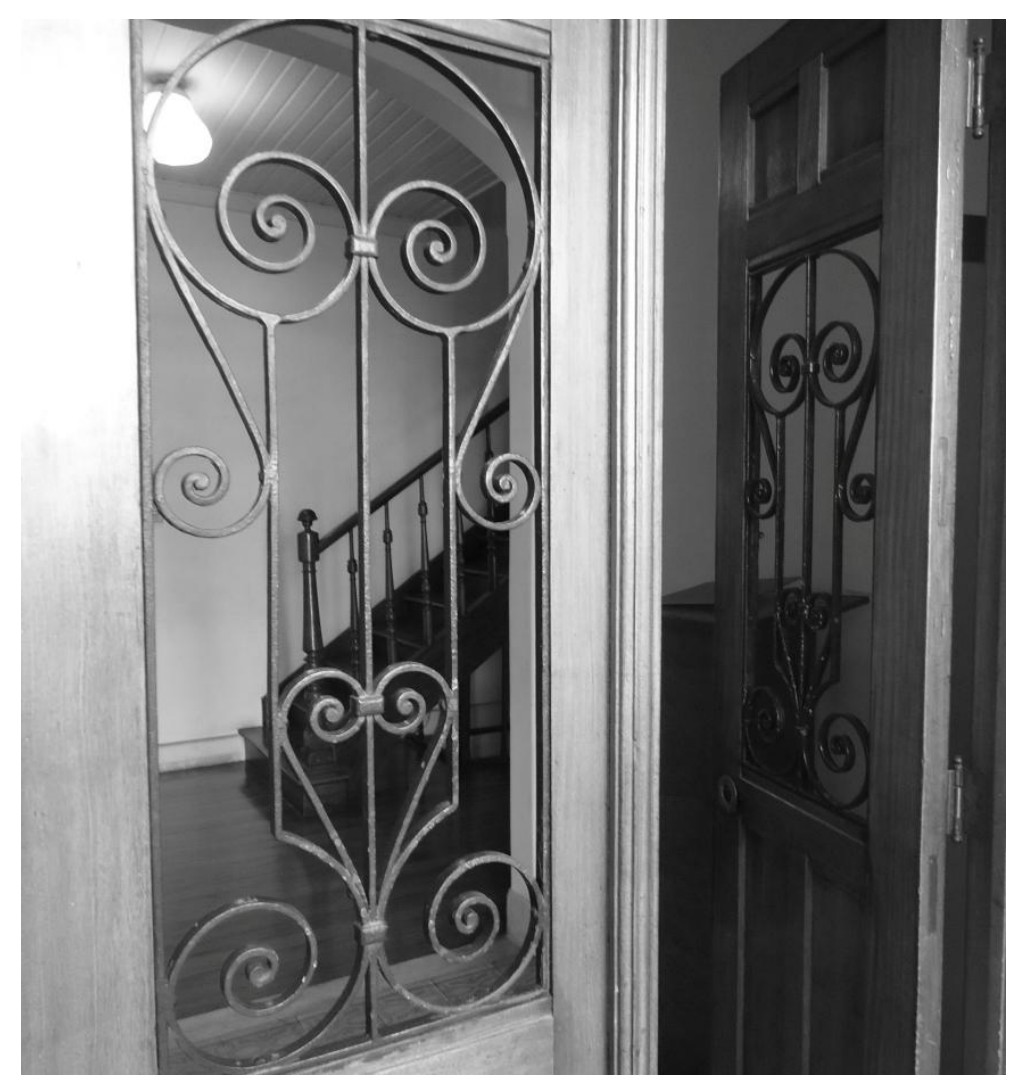

Imagem 21. Porta de entrada da Lopes Chaves, 2011.

Fonte: B. Dettino.

${ }^{35}$ GOMES, Paulo Emilio Salles. 10 anos de filmes sobre arte. São Paulo: Filmoteca III Bienal Museu de Arte Moderna de São Paulo, 1955.

${ }^{36}$ Ibidem.

${ }^{37}$ Folha da Tarde, 24 set. 1955. 
Em relação aos registros, existem tanto aqueles descritos, como o de Francisco de Assis Barbosa, quando, em 1944, entrevista o poeta, quanto reportagens póstumas em que a casa aparece como ilustração. Há ainda imagens do próprio Fundo Mário de Andrade, mas o foco é o próprio autor, assim a casa apenas está como cenografia para a pose do retratado.

Este conjunto documental, vídeos, fotografias, reportagens, materiais tão diversos que permitem recompor como seriam as lembranças expostas ao olhar. A partir do cotejamento entre elas, é possível averiguar algumas alterações na disposição de quadros e objetos da coleção Mário de Andrade, como será visto, quando se tratar dos cômodos da Lopes Chaves.

\section{Bônus com ônus de uma coleção}

Já em 1923, Mário de Andrade expressa apreciação sobre sua coleção "eu, que vivo entre livros atraentes, quadros de Anita Malfatti, bronzes de Brecheret e minha coleção de imagens antigas. [...] Minha coleção já tem seu interesse" ${ }^{38}$.A consciência do valor de sua coleção fora expressa em carta a Sérgio Milliet, de 20 de agosto de 1939, período em que residia no Rio de Janeiro, Mário de Andrade, ao discorrer sobre questões da crítica de arte, colocou a necessidade de critérios para tratar a plástica, diferente do gosto que agrada ou desagrada. Em sua argumentação, o autor exemplifica o caso, ao diferenciar o valor de sua coleção e a de Sérgio Milliet. Mário de Andrade atribui às suas escolhas sempre um olhar além, como no alpinismo deve-se olhar sempre para cima com segurança de pontos de apoio. Justamente, é a falta de normas e de alargamento de limites, que faltariam a Sérgio Milliet ${ }^{39}$.

Além disso, reconhecia o prazer na fruição de suas obras, tal como escreve para sua mãe, durante o período em que morou em Santa Teresa, no Rio de Janeiro, em 1940, "Fico horas inteiras de pura contemplação extasiada, não me canso de ver. E sei que não me cansarei nunca, porque jamais me cansei de olhar meus quadros, meus marfins e as coisas de que gosto" "40. Mário de Andrade era consciente tanto dos problemas ligados à conservação da matéria, tal como ataques biológicos e condições climáticas, quanto das dificuldades culturais de trabalhar com formas, volumes, espaço e texturas, como fonte de conhecimento transformador do presente e não meramente colecionista de obra-prima.

Todavia, a coleção Ihe impunha preocupações de variadas naturezas: disposição no espaço, organização, conservação, acondicionamento, armazenamento, segurança, questões recorrentes na manutenção das coisas da terra. Como registra a Prof. a Gilda de Mello e Souza,

Os livros se multiplicam sem parar e empilham-se pelas mesas, pelo chão, exigindo cada vez mais estantes. É preciso abrigar as imagens no oratório, providenciar pastas para as gravuras. Onde acomodar a multidão de cartas que não param de

\footnotetext{
${ }^{38}$ ANDRADE, Mário de. Crônica de Malazarte I. América Brasileira, Rio de Janeiro, out. 1923.

${ }^{39}$ DUARTE, Paulo. Mário de Andrade por ele mesmo. 2 ed. São Paulo: Hucitec/Secretaria da Cultura, Ciência e Tecnologia, 1977, p.327.

${ }^{40}$ CASTRO, Moacir Wernek. Mário de Andrade: exílio no Rio. Rio de Janeiro: Rocco, 1989, p. 124.
} 
chegar, as fichas de variados assuntos, as preciosas edições de luxo? Os quadros transbordam das paredes do estúdio para o hall, a escada, as salas, o porão. Cioso de seu tesouro, o colecionador teme os roubos e já não viaja tranquilo. Quando se ausenta, as cartas chegam inquietas, perguntando: _'Lourdes tem limpado os livros? Já chegaram as minhas estantes novas? Luis Saia foi restaurar o índio de Portinari?' A coleção, que salvara o colecionador de suas lembranças, fixa-se no espaço, como já o fixara no tempo ${ }^{41}$.

Em relação às condições climáticas brasileiras, cuja amplitude térmica e da umidade relativa foram sempre empecilho para a conservação das coleções, Mário de Andrade, desde os tempos que fora a Campos de Goitacazes, sabia dessas dificuldades. O ambiente quente e úmido propicia condições ideais para a proliferação de animais xilófagos e, também, de fungos. A coleção Lamego fora devorada por cupim que "viera buscando escureza e alimento, e tudo não eram mais que margens de papel. O centro, as gravuras, o passado, ou não existia ou era barriga de cupim. Ficaram margens" ${ }^{42}$.

Para além do clima, dos ataques biológicos, há ainda as dificuldades intrínsecas do material de certas peças, como por exemplo, a arte plumária que o escritor eliminara por não conseguir conservá-la eficientemente, levando-o a eliminá-la de sua coleção ${ }^{43}$.

Mário de Andrade preocupado com a integridade de seus papéis advertiu Anita Malfatti que não dobrasse "os desenhos que me manda" ${ }^{44}$, tal como fazia Victor Brecheret, pois vincava a estrutura do papel. Marcas que persistem até hoje, como na imagem abaixo.

${ }^{41}$ SOUZA, Gilda de Mello e. Homenagem a Mário de Andrade: o colecionador e a coleção. In: BATISTA, Marta Rossetti e LIMA, Yone Soares de. Coleção Mário de Andrade. Artes Plásticas. São Paulo: IEB USP, 1984, p. XVI.

${ }^{42}$ ANDRADE, Mário de. A Biblioteca Lamego, reproduzida na íntegra na apresentação da Prof.a. Myriam Ellis para a primeira edição do catálogo de manuscrito. NOGUEIRA, Arlinda Rocha; BELLOTO, Heloísa Liberalli; HUTTER, Lucy Maffei; CARDOSO, Maria Cecília de Castro, op.cit., p. 18

${ }^{43}$ BATISTA, Marta Rossetti. Coleção Mário de Andrade: religião e magia, música e dança, cotidiano. São Paulo: Editora da Universidade de São Paulo: Imprensa Oficial do Estado, 2004, p. 34.

${ }^{44}$ Correspondência de Mário de Andrade a Anta Malfatti, de 2 jun. 1924. BATISTA, Marta Rossetti (org.). Mário de Andrade, cartas a Anita Malfatti. Rio de Janeiro: Forense Universitária, 1989, p. 78. 

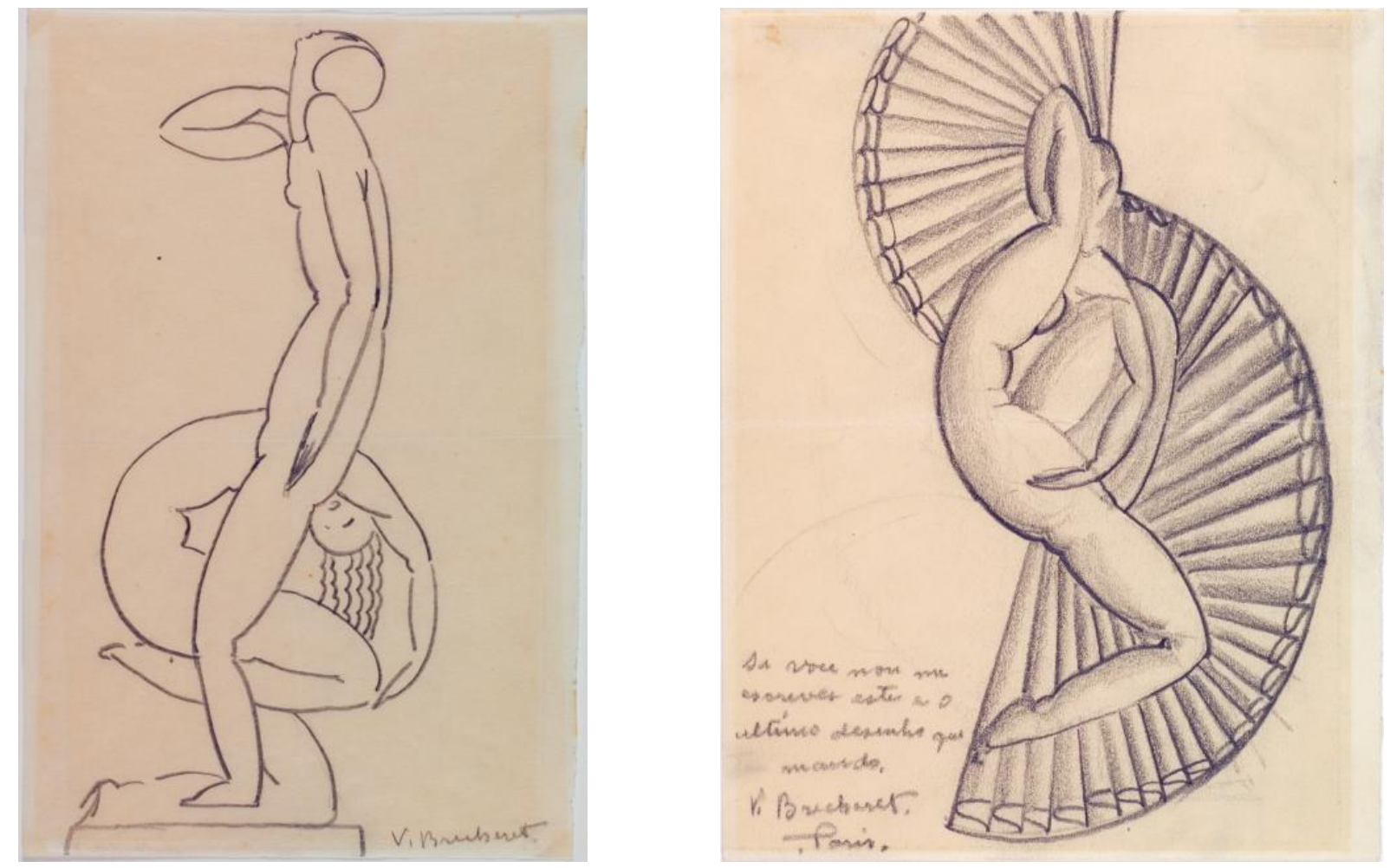

Imagem 22 e 23. De BRECHERET, Victor, Composição com dois nus, 1924 c., lápis sobre papel, $24.7 \times 16.0 \mathrm{~cm}$ e Pietá e Composição - nu feminino com leques, 1924 c., lápis sobre papel, 19.5 X $15.1 \mathrm{~cm}$.

Fonte: Coleção Mário de Andrade - Coleção de Artes Visuais do Instituto de Estudos Brasileiros da USP.

Os seus papéis flexíveis ficavam em pastas soltos, passíveis de serem manuseados, o possibilitando que as margens do papel, formassem uma moldura objetiva "não apenas para a nossa percepção, mas [...] existente no objeto mesmo, participando da sua natureza. Os apreciadores da gravura sabem o crime que é cortar as margens dela, ou imprimi-la sem margens" ${ }^{45}$, dessa forma, Mário de Andrade desaprovava a interferência causada aos desenhos quando colocados em moldura. Como alternativa fornecia a possibilidade do passe-partout, que

não chega a ser moldura. É uma terra de ninguém, um ambiente de transição que nas aquarelas e pastéis sugere o fechamento próximo da moldura verdadeira, que seria demasiado violenta se colocada junto à delicadeza do material plástico usado ${ }^{46}$

Contudo, almejava que as gravuras e desenhos corressem "abertos nas mãos e nos olhos todos, e eles armarão nosso braço, dirigirão nossa vontade, farão com que partamos", pois qualquer acréscimo seria uma proteção ao "sentimento verdadeiro do artista - que por mais homem que seja, será sempre um estético também - contras a intempéries do nosso

45 ANDRADE, Mário de. Do Desenho Claudéte I. Kronbauer. Mário de Andrade: cronista crítico das artes plásticas. São Paulo: FFLCH-USP, 1996, p. 325.

${ }^{46}$ Ibidem, p. 326. 
sentimento". O passe-partout de papel cartão funcionaria para amortecer a "virulência aberta do desenho", sem que se esvaísse a sua beleza ${ }^{47}$.

Em suas obras, o colecionador definia, pela janela do passe-partout, a abertura pela qual se deveria apreciar a obra. E vai além, risca o passe-partout, de tal forma a compor junto com o artista as soluções estéticas, como no desenho de lokanaan. Por sua vez, o conjunto, obra e passe-partout, era acondicionado em pastas de couro, guardadas ou em armário do hall superior, ou na cômoda localizada no estúdio.
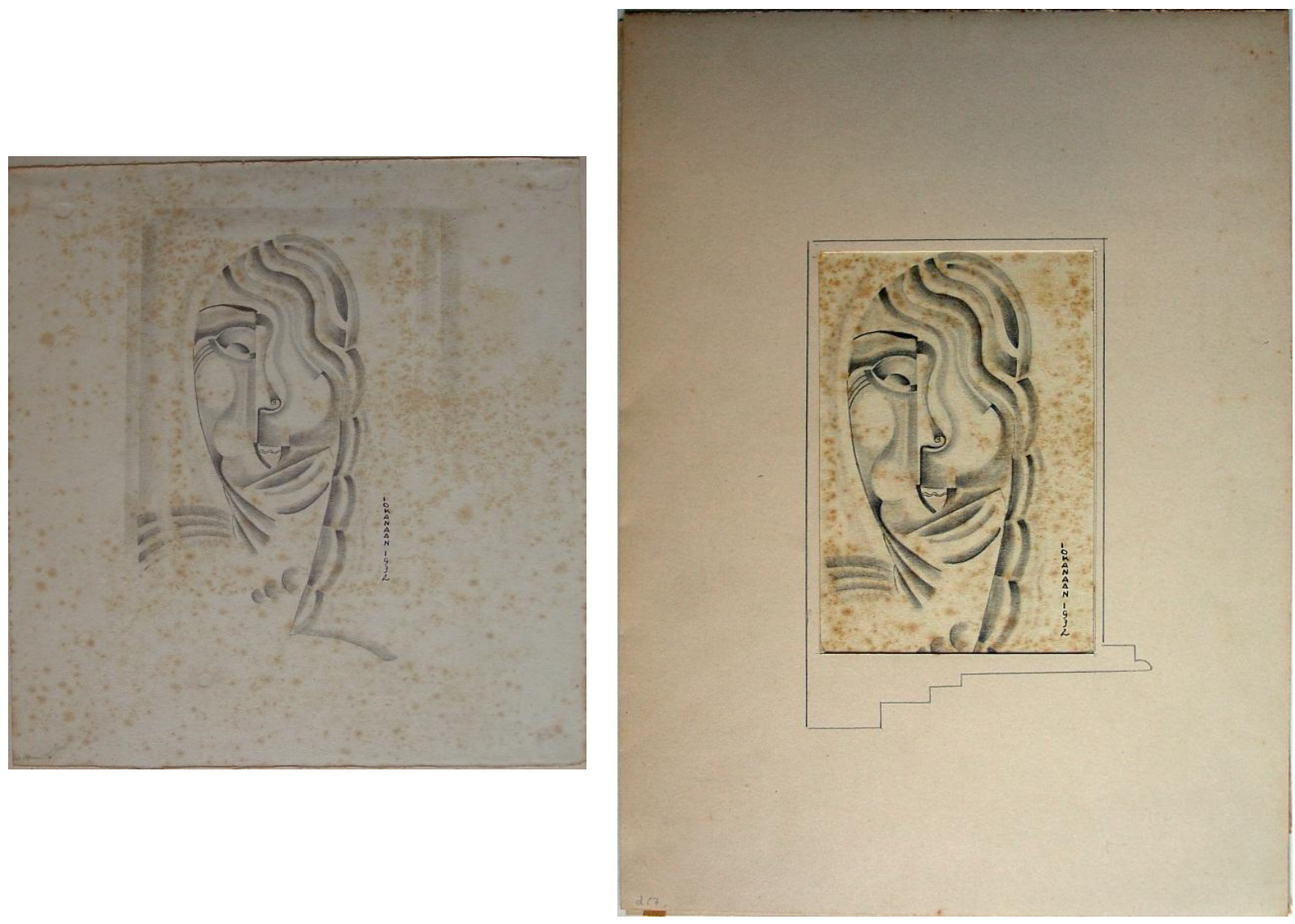

Imagem 24. Composição cubista de IOKANAAN, Joaquim Alves, 1932, lápis sobre papel, 24.0 X $23.4 \mathrm{~cm}$.

Fonte: Coleção Mário de Andrade - Coleção de Artes Visuais do Instituto de Estudos Brasileiros da USP.

Hoje, com o fomento das soluções relativas à conservação muito se avançou, pode-se observar que o colecionador, dentro de seu universo, seguia princípios como isolar cada uma das obras. Infelizmente, os materiais que foram utilizados agiam de tal forma a acidificar o papel, generalizando as manchas.

${ }^{47}$ Ibidem. 

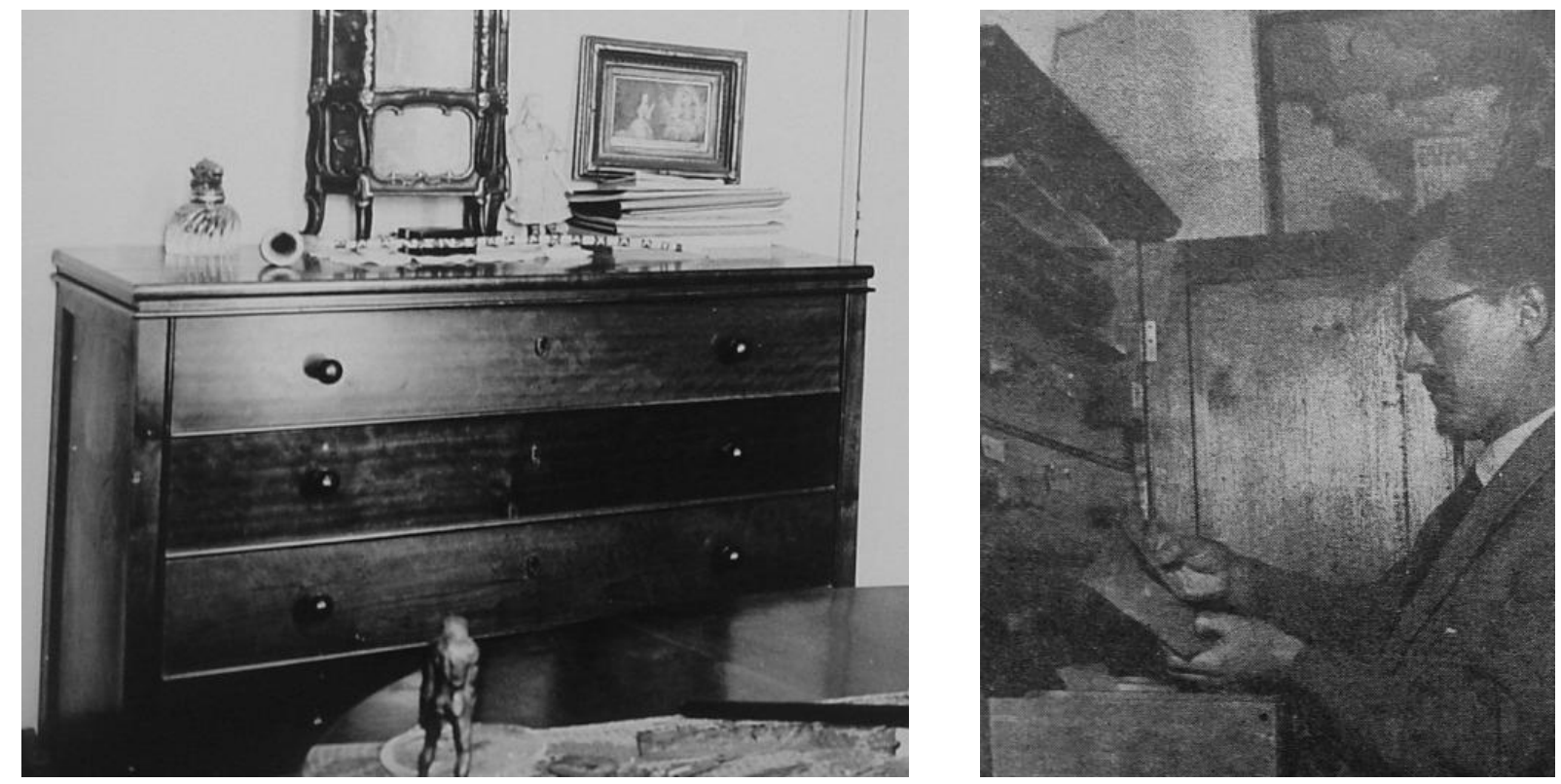

Imagem 25 e 26. Cômodo do estúdio e móvel do hall manuseado pro Zé Bento, do andar superior.

Fonte: Casa de Mário de Andrade. SARNO, Geraldo (dir.); FARKAS, Thomaz (fot.). São Paulo: IEB USP, 1968.

Fonte: MARTINS, Justino. Presença e Ausência de Mário de Andrade. Ed. Keffel (fotografias). Revista do Globo. Porto Alegre, 23 fev. 1946.

O colecionador defendia o contato direto com a obra de arte, nesse sentido qualquer interferência entre o olhar e a matéria artística causaria um efeito devastador na apreciação. Para ele, "os ataques do tempo patinam a obra de arte, Ihe acrescentando um valor estético maravilhosamente sensível" ${ }^{48}$. Assim, a manutenção da pátina do tempo, permite que os diversos tempos das obras, as suas camadas invisíveis estejam ao alcance do fruidor. Inclusive chega a desaprovar o uso de verniz nas telas, possivelmente porque os produtos utilizados, até então, causavam alteração na coloração da camada pictórica ${ }^{49}$.

Em relação às pinturas, mantinha boa parte delas com molduras, contudo restou pouca documentação sobre as escolhas desse elemento que "define o microcosmo pictórico como radicalmente heterogêneo ao universo que o cerca, ela indica a exterioridade ontológica da imagem que rege em relação às imagens do mundo exterior" 50 . Possivelmente, o colecionador possuísse "homem que já enquadrou os meus outros quadros" ${ }^{51}$, mas sem maiores definições suas sobre material, textura, ou cor ${ }^{52}$. É possível que algumas de suas obras já viessem com este elemento, como é o caso de $O$ mamoeiro de Tarsila do Amaral, cuja execução fora de Pierre Legrain ${ }^{53}$.

48 Ibidem, p. 325.

${ }^{49}$ Atualmente, esta camada de proteção é aplicada com novos materiais que evitam este efeito.

${ }^{50}$ BAZIN, André. In: GOMES, Paulo Emilio Salles. 10 anos de filmes sobre arte. São Paulo: Filmoteca III Bienal Museu de Arte Moderna de São Paulo, 1955.

${ }^{51}$ Correspondência de Mário de Andrade a José Bento Ferraz, Rio de Janeiro, 23 de outubro de 1939. Fundo José Bento Ferraz - Arquivo IEB USP.

${ }^{52}$ As molduras atuais das obras de arte de Mário de Andrade, de perfil chanfrado de madeira pintada de prata, imitando alumínio, substituíram a originais, que se mantêm como parte de seu acervo e estão no aguardo de uma pesquisa específica.

${ }^{53}$ AMARAL, Aracy. Tarsila: Sua obra e seu tempo. São Paulo: Ed. 34 / Edusp, 2003, pp. 231-232. 


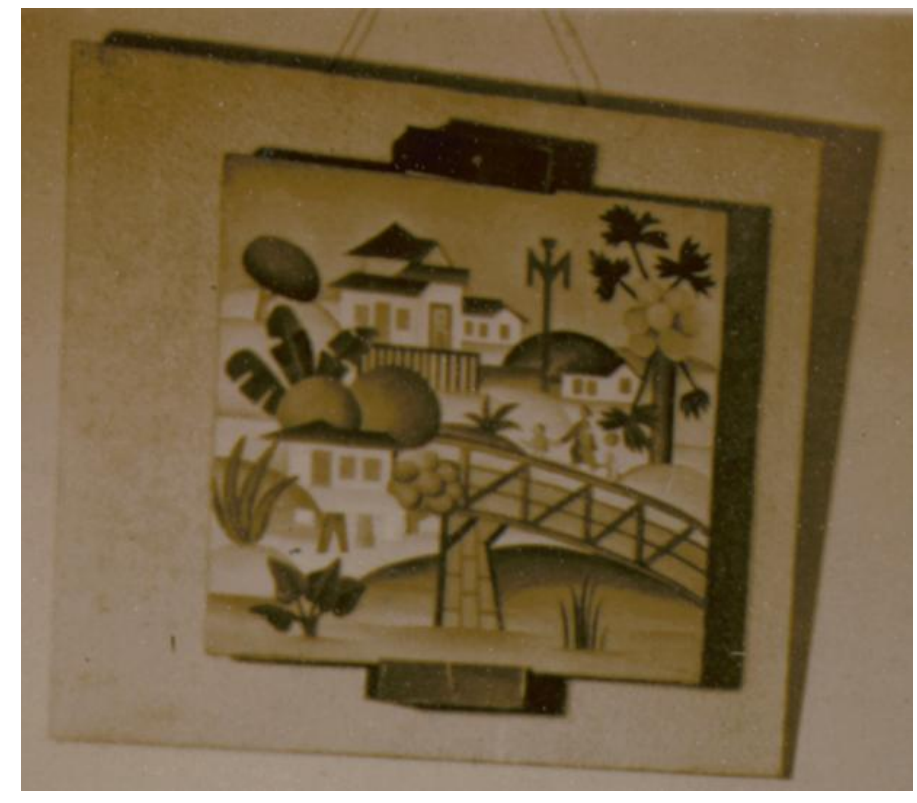

Imagem 27. O mamoeiro, de Tarsila do Amaral, com moldura de Pierre Legrain

Fonte: Fotografia do Fundo Mário de Andrade - Arquivo do Instituto de Estudos Brasileiros da USP.

Quando Mário de Andrade seguiu para o Rio de Janeiro, solicitou a seu secretário Zé Bento que enviasse algumas de suas obras, tendo, porém, anteriormente pedido que fossem emolduradas, conforme carta de 23 de outubro de 1939. A sua escolha era levar para a capital federal as seguintes obras: seu Retrato, realizado por Lasar Segall, Mamoeiro, de Tarsila do Amaral, Família do fuzileiro naval, de Alberto da Veiga Guignard, Composição (Retirantes), de Cândido Portinari, a Nossa Senhora do Carmo antiga, o São João Evangelista antigo, A Colona, também de Portinari, o Oxê de Xangô, a Cabeça de Cristo, de Victor Brecheret e, por fim seu altarzinho antigo. Assim, o colecionador recomenda a contratação de um "bom técnico", capacitado a acondicionar admiravelmente sua coleção para que não sofresse qualquer risco de dano. Sugere ainda que as caixas de transporte sejam preenchidas com palha a fim de calçá-la, evitando qualquer movimentação. Aproveita também para pedir que, nos interstícios da embalagem de transporte, sejam colocados seus "copinhos de cristal, os compridos", algumas almofadas, seu corta papel de tartaruga e sua máquina de tomar banho de luz ${ }^{54}$. Além disso, cuida para que seja contratada a empresa Expresso Paulista e, também, se fizesse seguro de "três contos", que possivelmente cobrisse acidentes no transporte ou eventual furto ${ }^{55}$.

Outra maneira de reconhecimento eram as solicitações de empréstimo, como por exemplo, quando Cândido Portinari pediu para que duas de suas telas fizessem parte de uma exposição em Nova York, em $1940^{56}$, com o agravante de uma ter sido presente do artista, o que não era habitual, conforme carta a seu secretario:

${ }^{54}$ Correspondência de Mário de Andrade a José Bento Ferraz, Rio de Janeiro, 10 de agosto de 1938. Fundo José Bento Ferraz - Arquivo IEB USP.

${ }^{55}$ Os procedimentos necessários para movimentação de obras, tais como transporte e manuseio adequados, bem como providência de seguro, são fundamentais até os dias de hoje.

${ }^{56}$ Museum of Modern Art (New York, NY). Portinari of Brazil, 8 out.-17 nov. 1940. [individual - 186 obras]. Disponível em <http://www.portinari.org.br/ppsite/ppacervo/listaevesTipo.asp\#>. Acesso 25 fev. 2012. 
Agora temos que fazer uma safadeza. O Portinari me pediu emprestado meu Retrato e a Composição (em branco e marrom), pra uma exposição de obras dele que vai haver em Nova York. Ora, tenho muito medo de perder esses quadros na situação atual do mundo. Como ele me telefonou só hoje e os quadros tem que estar aqui no mínimo dia 7 para serem encaixotadas no dia 8 pra partir num vapor que sai aqui dia 19 , você mande já, pra casa dele, (avenida Atlântica, 228, Candido Portinari), o meu retrato com moldura, porte pago aí, pelo Expresso Paulista. Quanto ao outro quadro, mesmo que chegue com tempo você não mande, e no dia 8, telegrafe pra mim dizendo 'quadro chegado oito da tarde. Meu Retrato enfim não tenho o direito de recusar, porque foi dado, mas a Composição me custou 3 contos. $^{57}$

Dessa forma, a coleção atinge o ponto de não ser somente fomentada pelas exposições, e passa, então, a integrá-las com a importância de suas obras. Outro caso, é o pedido de Alberto Guignard, também para sua pintura $A$ família do fuzileiro naval seguir para uma mostra, contudo em correspondência à Murilo Miranda expressa a dificuldade em recuperar seu quadro:

Preciso absolutamente que você me preste um favor difícil. É o caso do Guignard. Como você sabe ele tomou emprestado, a Família do Fuzileiro Naval. E eu comprei, paguei, e tenho o recibo. Ora, não há meios por mais esforços que eu faça do Guignard me entregar o quadro outra vez. Positivamente, não posso mais crer que se trate de simples desleixo da parte dele. Deve existir qualquer coisa. 0 quadro foi pago aqui aos diretores da exposição em que ele estava, não regateei nada. Apenas esperei e dei o preço mínimo pedido pelo próprio Guignard. Conforme me disseram os homens da exposição. Ora, eu preciso desse quadro e já tenho um lugar definido numa das paredes de meu estúdio ${ }^{58}$.

Ainda em relação à publicização da coleção, Mário de Andrade preocupava-se me manter cópias de alguns de seus quadros para reproduções, como revela a Moacir Werneck, em 3 de fevereiro de 1945: "Mandei faz justo dois dias tirar fotos novas deles (negativos) pra poder reproduzi-los à vontade. Não quero mais chatear nem Segall nem Portinari, os quais, quando empresto os negativos pra reproduções, me presenteiam logo com meia-dúzia de reproduções que pagam" ${ }^{59}$.

${ }^{57}$ Correspondência de Mário de Andrade a José Bento Ferraz, Rio de Janeiro, 2 de julho de 1938. Fundo José Bento Ferraz - Arquivo IEB USP.

${ }^{58}$ ANDRADE, Mário Cartas a Murilo Miranda (1934-1945). Rio de Janeiro: Editora Nova Fronteira, c1981, p. 88.

${ }^{59}$ CASTRO, Moacir Wernek. Mário de Andrade: exílio no Rio. Rio de Janeiro: Rocco, 1989, p. 229. 
N este capítulo, Casas e lugares que falam de Mário, verificou-se a relevância das ambiências em diferentes níveis, seja da cidade, seja da casa, para a constituição da sua coleção de artes. A Paulicéia e as diversas casas que aqui morou são fontes para demonstrar sua estreita relação com a cidade e, consequentemente, com suas pinturas e desenhos. Assim, o espaço para o colecionador extrapola os limites de sua própria coleção chegando à escala da cidade, passando inclusive pela sua residência.

Seja a cidade do seu tempo de juventude, seja a cidade em vias de se tornar a grande metrópole brasileira, Mário relacionou-se a ela de forma estreita, mesmo que às vezes conturbada, levando-o a referir-se recorrentemente aos endereços de suas casas: Aurora, Largo Paissandu, Lopes Chaves.

Fora a Rua Aurora, dos tempos de sua primeira infância, as demais são testemunhas de sua vida e, por analogia, também de sua coleção, como as primeiras obras ainda no Largo Paissandu. A casa da Rua Lopes Chaves é o coroamento deste processo, local em que suas escolhas tomam forma, ou melhor as paredes e cômodos. Tanto assim, que em seu célebre texto $O$ movimento modernista, de 1942, coloca-a no rol dos salões da orgia intelectual, juntamente com as residências aristocratas de Paulo Prado, Dona Olívia Guedes Penteado e Tarsila do Amaral.

Espaços estes que podem ter funcionado como contato com as vanguardas internacionais e, também, como modelo para a formação de sua coleção, mesmo consciente da distinção social existente entre eles. Além disso, esses salões proporcionam exemplos de disposição dos quadros, Dona Olívia construíra um pavilhão exclusivo para a arte moderna, projetado juntamente com suas obras, a fim de funcionar como um todo integrado, em que as telas e esculturas pudessem ser observadas isoladamente e, também, como parte do conjunto. A casa de Tarsila proporcionara-Ihe a solução de arranjo, em um espaço público residencial: a sala de visitas, cuja solução fora a distribuição das obras por um lado de artistas estrangeiros ligados aos movimentos vanguardistas e, por outro, das suas produções artísticas. Em ambos os casos, há a intencionalidade da exposição ao olhar, que não passara despercebida para Mário de Andrade.

Quando distribui sua coleção pelos cômodos da Lopes Chaves, Mário de Andrade deveria harmonizar os seus anseios de colecionador, com o convívio familiar, conciliando os usos públicos e privados da casa com os demais moradores. Há que se reconhecer a sua mão magnânima, possivelmente, sobrepondo-se à dona da casa. As escolhas do colecionador ao exibir suas lembranças ao olhar valeram muitos registros, tanto visuais quanto escritos.

Dois filmes foram emblemáticos para documentar, de maneiras distintas, A Casa de Mário de Andrade. Em 1955, de Ruy Santos, focado na difusão de obras de arte por essa nova linguagem que, naquele momento, era o cinema; entretanto, ultrapassa esse primeiro ímpeto por trazer à baila outros interesses do colecionador, como por exemplo, seus santos católicos e as pesquisas etnográficas.

Em 1968, criou-se uma sinergia de tal modo que os interesses de Geraldo Sarno e Thomas Farkas iam ao encontro da recepção do acervo de Mário de Andrade por parte do Instituto de Estudos Brasileiros, levando-os a filmar a Lopes Chaves justamente no momento anterior ao seu desmanche, vale dizer, quando as coisas da terra seguiriam para a Universidade. 
Os dois filmes em conjunto com depoimentos, entrevistas e reportagens, permitiram o estudo das obras arte in loco, tal qual a vontade de seu colecionador. Inclusive, possibilitaram identificar alterações de posição, mesmo que poucas, durante o tempo em que aguardava sua ida ao regaço duma casa de cultura. As lacunas deixadas por esses registros foram, quando possível, sanadas pela gentil entrevista do Prof. Antônio Cândido, a qual agradeço imensamente, por permitir o entendimento dos usos e funcionamentos da casa.

A sua coleção de artes plásticas construída em bases de olhar além, acarretou o prestígio ainda a seu tempo, tanto pelo próprio colecionador, quanto por seus coetâneos, transformando-se inclusive como modelo para futuras coleções. Contudo, as coisas da terra necessitam de cuidados, tais como conservação e acondicionamento, armazenamento e organização, segurança, os quais não passaram despercebidos de Mário de Andrade. 
3. MÁRIO ENTRE SUAS COISAS DA TERRA 


\section{Pela noite de barulhos espaçados...}

(Junho de 1929)

Pela noite de barulhos espaçados, Neste silêncio que me livra do momento E acentua a fraqueza do meu ser fragilíssimo, Eu me aproximo de mim mesmo No espanto ignaro com que a gente se chega pra morte.

Meu espírito ringe cruzado por dores sem nexo, Numa dor unida, tão violentamente física,

Que me sinto feito um joelho que dobrasse. A luz excessiva do estúdio desmancha a carícia do objeto, Um frio de vento vem que me pisa tal qual um contato,

Tudo me choca, me fere, uma angústia me leva, Estou vivendo idéias que por si já são destinos E não aconselho mais minhas visões.

Remate de males, Marco da viração, 1930

Mário de Andrade 


\section{Mário e as lembranças expostas ao olhar}

O levantamento arquitetônico da residência da Lopes Chaves, associado à coleta imagética da casa de Mário de Andrade em diferentes tempos, permitiu a remontagem de boa parte dos seus cômodos, pelo menos daqueles que possuíam obras e objetos, a fim de reconstituir o espaço domiciliar. Dessa forma, segundo a definição de Pomian, ser possível trazer o "invisível" para a fruição, com olhos sempre para a constituição da coleção Mário de Andrade, em especial a artística, uma vez que se acredita que "a afinidade do colecionismo com a organização doméstica nos ajuda a entender como a casa torna-se um campo operacional onde as ações com os objetos produzem subjetividade" ${ }^{1}$.

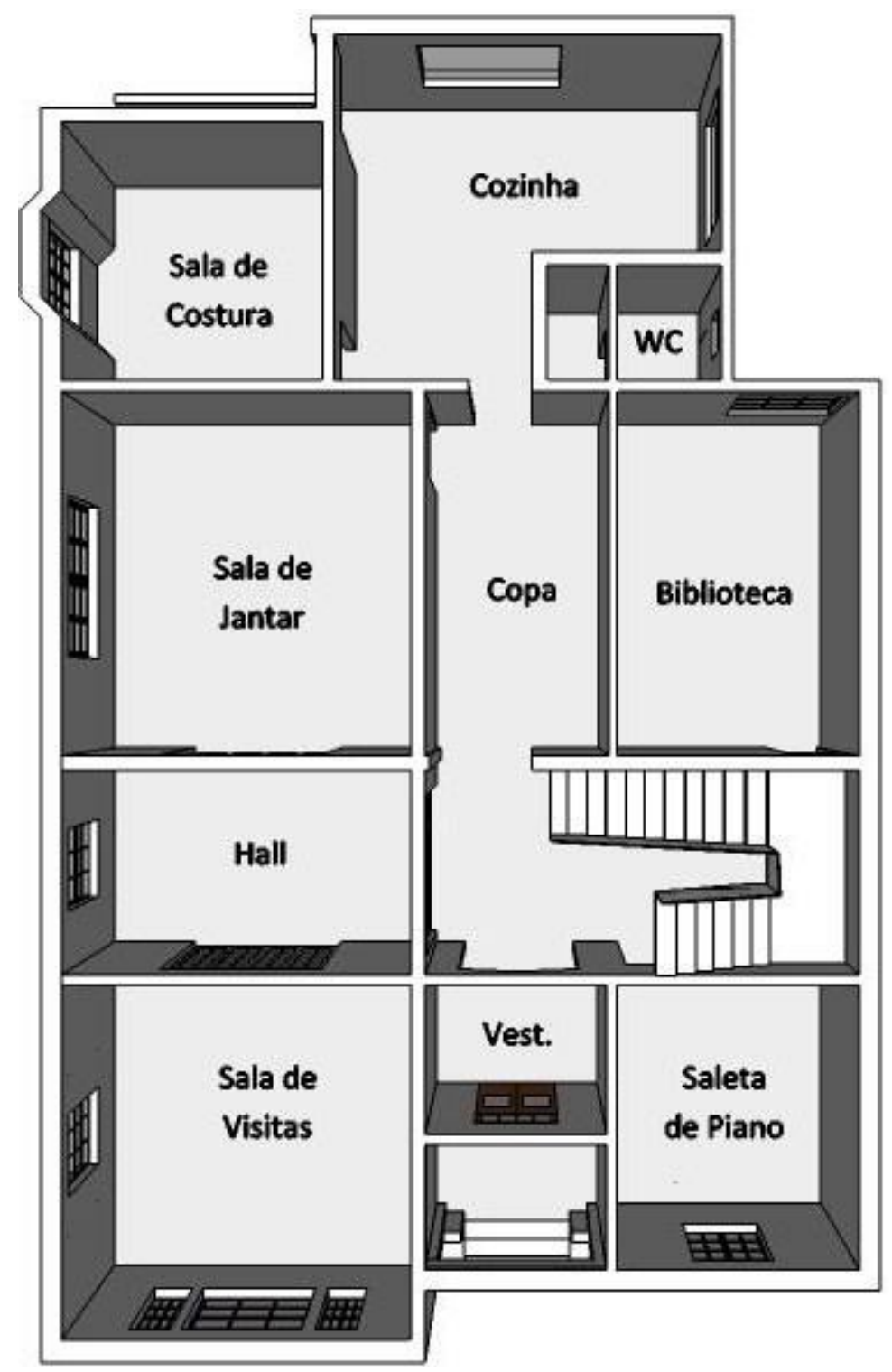

Planta 3. Térreo da Rua Lopes Chaves.

Fonte: Levantamento arquitetônico in loco, documentação da Oficina da Palavra Casa Mário de Andrade e maquete eletrônica realizada por Júlia Ferrari e Camila Lacerda, 2012.

${ }^{1}$ CARVALHO, Vânia Carneiro de. Gênero e Artefato: o sistema doméstico na perspectiva da cultura material São Paulo, 1870-1920. São Paulo: Edusp / FAPESP, 2008, p. 92. 
Já nas lembranças da Prof.a Gilda, "os quadros, que se mantinham discretamente no estúdio, foram se apossando do andar térreo. Primeiro da sala do piano de cauda, em seguida, da salinha do meio e por último da sala de jantar" ${ }^{2}$. Neste pavimento, além das salas de visitas, de jantar e de aula de música, tratadas mais detalhadamente a seguir, havia uma biblioteca, prateleiras que forravam as paredes de livros, local em que ficava também o telefone. Quando Gilda de Moraes Rocha ali morava, era nesta sala que realizava seus estudos e também local em que ficava o telefone ${ }^{3}$.

Já ao fundo deste piso, havia a copa adjacente à cozinha que possuí um pequeno lavabo, e um cômodo que seria a sala de costura, na qual ficavam Dona Mariquinha e Dona Nhanhã, conforme, lembranças da Prof.a Gilda:

Vejo-o atravessar a copa, sempre escura, entrara à esquerda na salinha dos fundos, onde as duas velhinhas estão trabalhando. Senta-se junto à grande mesa central, de pés torneados, [...]. Brinca um pouco com a mãe e a tia, tem o prazer um pouco perverso de atiçar uma contra a outra, tomando partido da madrinha quando as coisas azedam 4 . Agora se levanta, põe na mesinha de pau-ferro, no canto à esquerda da janela, os livros que trouxe da rua. 'Mais livro pra cortar' $^{5}$, diz para as duas, como se estivesse passando uma tarefa para quem não tem o que fazer. Toma a benção das duas e sobe rindo para o quarto. ${ }^{6}$

Por fim neste pavimento, a cozinha. Domínio de Tana, cozinheira de Mário por 19 anos, que casada não morava na casa" , "mestra-cuca extraordinária, orgulhosa dos patrões ilustres [Dr. Vicente de Carvalho e Dr. Sílvio de Campos], que já havia servido" fazia peixes, carnes e "ramequer", sua famosa empadinha. Do convívio com o escritor de Macunaíma, experimentou várias receitas sugeridas por ele "procurando tirar partido do paladar delicadíssimo de certas frutas do Norte" ${ }^{8}$.

Ao subir para o primeiro andar, havia os quartos: um para cada uma das "velhinhas", um terceiro para Gilda Rocha, cuja entrada se dava pelo quarto da mãe de Mário e não pelo corredor, outro que possivelmente servia para visitas, e, para Mário, o quarto de dormir contíguo ao seu estúdio, todos ligados por um grande hall de distribuição.

2 SOUZA, Gilda de Mello e \& CANDIDO, Antonio. A lembrança que guardo de Mário. Revista do Instituto de Estudos Brasileiros, São Paulo, 36: 9-25, 1994, p. 19.

${ }^{3}$ Ibidem.

${ }^{4}$ Antonio Candido corrobora com esta questão tanto neste mesmo depoimento, p. 14, quanto em depoimento à A., em 27 out. 2011.

${ }^{5}$ A abertura dos livros era fundamental, uma vez que as suas folhas não vinham refiladas, necessitando que fosse "aberto", se não o leria. É interessante notar que Mário de Andrade possui duplicatas de publicações de seus amigos contemporâneos: um com dedicatória com as páginas fechadas e outro 'cortado' para leitura.

${ }^{6}$ SOUZA, Gilda de Mello e \& CANDIDO, Antonio. A lembrança que guardo de Mário. Revista do Instituto de Estudos Brasileiros, São Paulo, 36: 9-25, 1994, p. 18.

${ }^{7}$ Em depoimento de Antonio Candido, a A. em 27 out. 2011, o Professor recorda-se que seus ternos não lhes servindo mais, entregava-os ao marido de Tana.

8 Idem. 
A partir da documentação analisada, fez-se um levantamento das obras expostas, de acordo com a ambientação do colecionador, para os cômodos, tanto do térreo: vestíbulo, saleta de piano, sala de visitas e de jantar, escada; e também do piso superior: hall, antessala, estúdio e quarto de dormir.

\section{Vestíbulo}

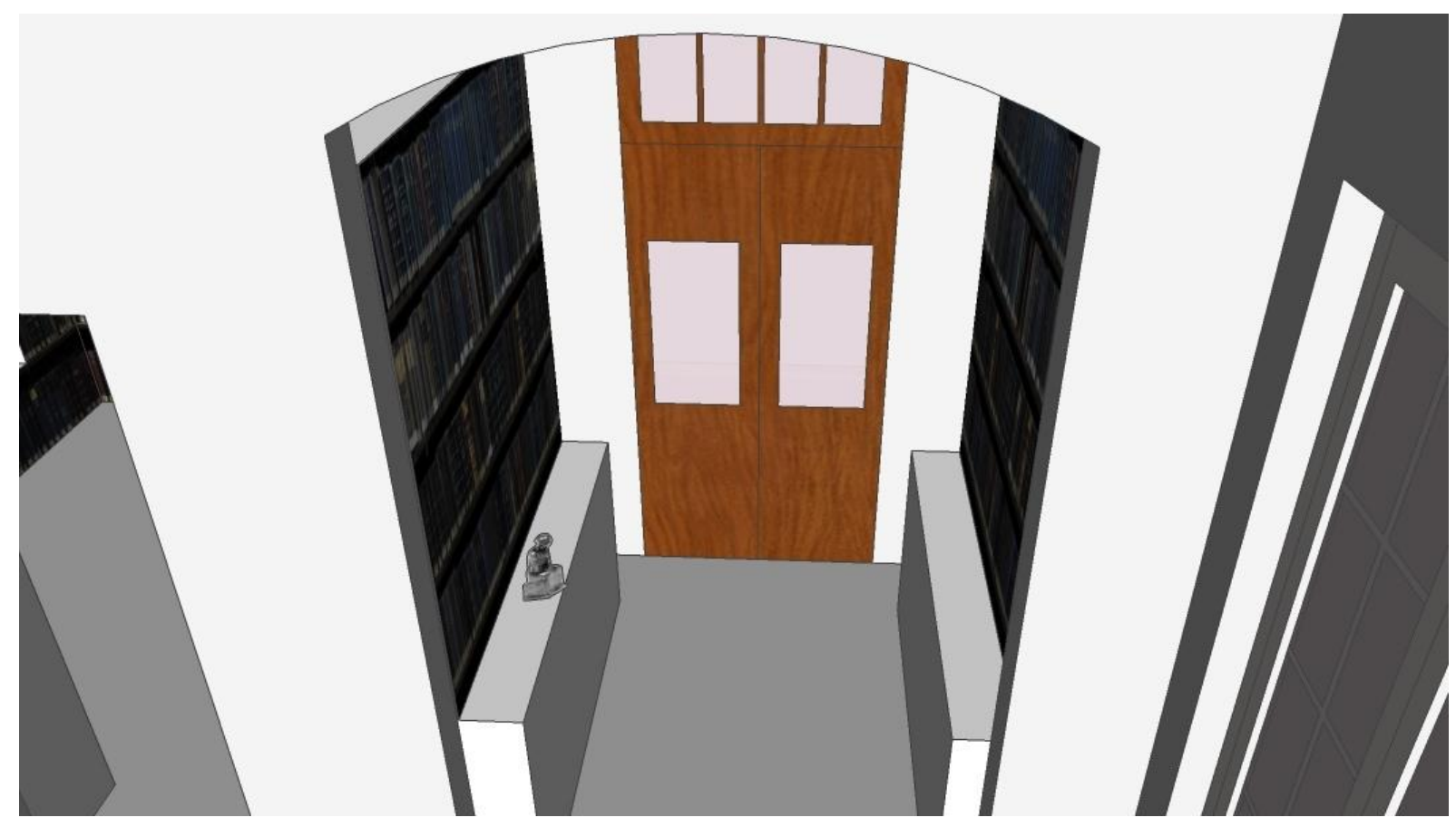

Imagem 28. Vista do vestíbulo.

Fonte: Maquete eletrônica da casa de Mário de Andrade. Camila Lacerda, 2012.

Após passar pelo pequeno jardim frontal da Lopes Chaves, o visitante adentra a casa pelo vestíbulo cercado por prateleiras completa de livros, que segundo a Prof.a Gilda emanava:

[...] o seu cheiro de maçã e cháLipton, a bulha da empregada Sebastiana na cozinha, o gosto da água de seu filtro de pedra. Tenho a impressão de que ouço o barulho da chave na fechadura e vejo Mário entrar no vestíbulo, como costumava fazer quando vinha da rua: empurrando o chapéu para o alto da cabeça, a fim de que a calva não recebesse de repente a rajadinha de ar fresco. ${ }^{9}$

As primeiras sensações do interior da casa chegam ao visitante por meio do vestíbulo: o cheiro do chá, os ruídos e gostos da cozinha, o som da chave na fechadura, o ar que

${ }^{9}$ SOUZA, Gilda e Antonio Candido de Mello e. A lembrança que guardo de Mário. In: Revista do Instituto de Estudos Brasileiros, São Paulo, 36, 1994, p. 17. 
circula, tudo é sentido quando o visitante se introduz na residência, marcando em seu imaginário às primeiras impressões. Para isso o mobiliário típico devia comportar "fortes cabides, um porta-chapéus" ${ }^{10}$. Na casa de Mário de Andrade, é possível ainda verificar, além do cabideiro, prateleiras com portas de madeira até a altura da perna e portas de vidro daí até o teto.

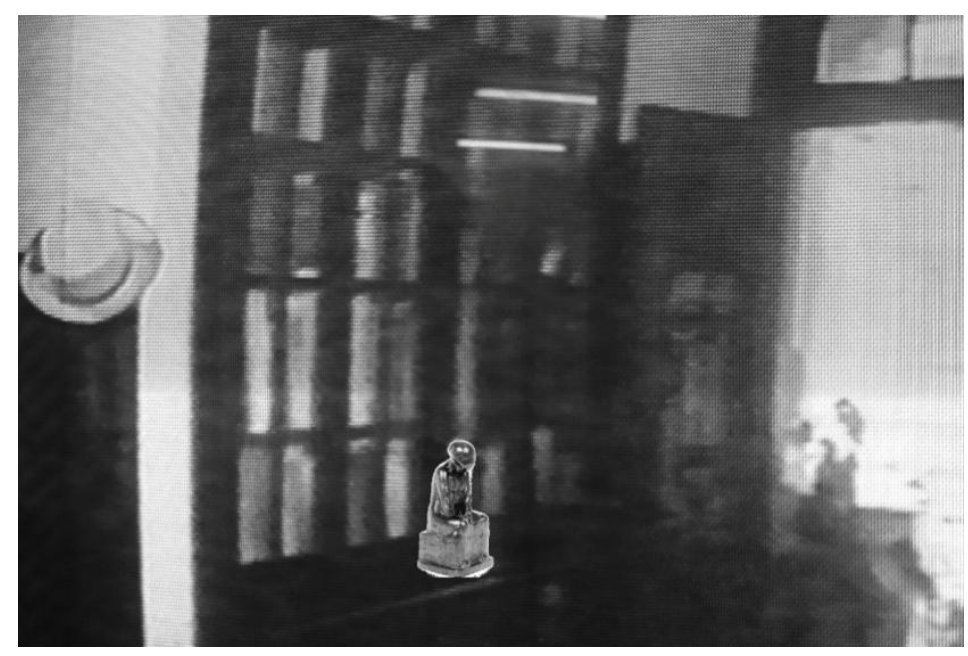

Imagem 29. Vestíbulo da Lopes Chaves, com destaque para o porta-chapéu e a escultura Mãe e filho.

Fonte: Casa de Mário de Andrade. SARNO, Geraldo (dir.); FARKAS, Thomaz (fot.). São Paulo: IEB USP, 1968.
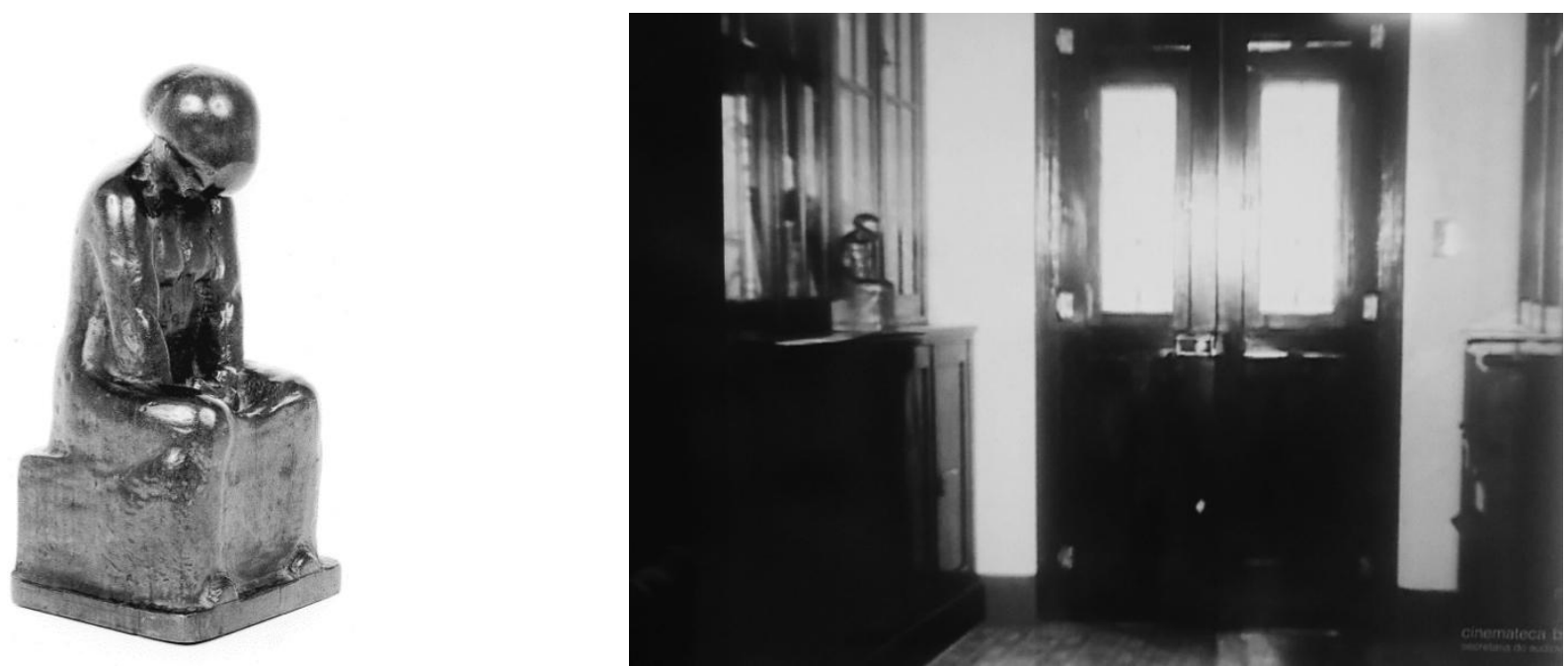

Imagem 30. Vestíbulo da Lopes Chaves, vista de quem sai da casa.

Fonte: A Casa de Mário de Andrade. SANTOS, Ruy (direção). São Paulo: Rangel Filmes Ltda, 1955.

Imagem 31. Mãe e filho, de HAARBERG, Wilhelm. s.d. madeira, $31.5 \times 14.7 \times 14.7 \mathrm{~cm}$.

Fonte: Coleção Mário de Andrade - Coleção de Artes Visuais do Instituto de Estudos Brasileiros da USP.

${ }^{10}$ CARVALHO, Vânia Carneiro de, op. cit., p. 134. 
Justamente este móvel servia de base para a escultura Mãe e filho de Wilhelm Haarberg ${ }^{11}$. Este artista alemão estudara, primeiramente, escultura na Escola de Artes e Ofícios de Kassel (1909 -1912) e, depois, para professor na Academia de Artes, desta mesma cidade. Contudo eram anos de guerra, e o escultor interrompeu seus estudos quando esteve em combate de 1914 a 1918, quando foi atingido gravemente. Assim, em 1919, concluiu sua formação de professor e já no ano seguinte veio para o Brasil a convite da editora Weiszflog, que em 1921 se fundiria à Melhoramentos. ${ }^{12}$

Durante sua estada no Brasil, entre 1920 e 1925, Haarberg relacionaou-se com membros da colônia alemã, entre eles Aurélio (Aurel) Zimmermann, falecido em fevereiro de 1920, montando seu ateliê na edícula da residência da viúva Zimmermann. O trabalho ali realizado no ateliê o tornou conhecido pelas escolas alemãs de São Paulo, nas quais veio lecionar, como por exemplo, a Escola Alemã "Olinda", atual Colégio Porto Seguro. O contato com Mário de Andrade se deve à sua atividade no ateliê da Rua Frei Caneca, 143, em 1921, momento em que o escritor estava "atento à procura de novos valores" ${ }^{13}$.

Segundo a pesquisadora Marta Batista, além da procura do novo, Mário de Andrade inteirava-se da cultura alemã, aproximando-se do expressionismo, em contraposição a seu "francesismo". Em 1921, o poeta compara Haarberg a "Barlach, vale lembrar que o conhecia apenas por reproduções, concluindo que é mesmo um expressionista, pela simplificação e pela força de expressão alcançada" ${ }^{14}$. Possivelmente, foi do contato entre os dois que levou o escultor a expor esculturas em madeira, na Semana de Arte Moderna de 1922. Contudo, a documentação existente não permite uma afirmação categórica sobra à escultura Mãe $e$ filho ser uma das obras listadas no catálogo da Semana, numeradas como 14 ou 15.

De qualquer forma, a sua disposição no vestíbulo da Lopes Chaves leva o visitante à participação de Mário de Andrade na Semana, que vai além de sua atuação como poeta, pois sua pesquisa estética o levava a alargar as fronteiras visuais, tal como o aprofundamento das questões do expressionismo, seja em defesa de Anita Malfatti, seja com as esculturas de Haarberg.

Mãe e filho, colocada abaixo do ângulo de visão do visitante, faz com que se repita a movimentação da própria escultura compacta de pequenas dimensões, mas com características de monumentalidade ${ }^{15}$. Vale dizer, a figura sentada direciona seu olhar para a pequena figura em seu, sobre suas pernas, tal como o visitante dirige sua atenção ao ponto focal da escultura, o gesto da mãe curvada sobre o filho. Seria então como uma deferência ao movimento modernista que fora destruidor, contendo em si os germes que transformariam a realidade brasileira, tal como Mário de Andrade aventou em $1942^{16}$.

\footnotetext{
${ }^{11}$ Segundo depoimento de Antonio Candido, a A. em 27 out. 2011, era a escultura A cabeça de Cristo nesta posição, contudo preferimos adotar a escultura de Haarberg pela extensiva documentação visual que coloca Mãe e filho na entrada da casa.

${ }^{12}$ BATISTA, Marta Rossetti. Centenários Modernistas I: Wilhelm Haarberg (1891 - 1986). São Paulo: Coleção de Artes Visuais IEB USP, 22 maio a 5 jul. 1991.

13 Ibidem.

${ }^{14}$ Ibidem.

${ }^{15}$ Ibidem.

${ }^{16}$ ANDRADE, Mário de. O movimento modernista, op. cit., p. 266.
} 
Para além da obra, o interesse pelo escultor alemão estende-se ao ensino de arte proposto por Haarberg, uma vez que levou trabalhos de seus alunos para a Exposição de Arte Alemã, em 1923. Segundo Mário de Andrade, estas obras seriam as "mais vivas atrações" da mostra, elogiando o "excelente professor" e a sua "orientação clarividente", para o propósito de educar "na justa noção de arte, capazes de compreender a escultura como jogo da luz no volume!" ${ }^{17}$. Quando já estava no Departamento de Cultura realizou o concurso de Desenho Infantil, no qual os alunos deveriam desenhar sem qualquer interferência das professoras ${ }^{18}$, reiterando a postura de busca do novo e original, presente no movimento modernista.

\section{Saleta de piano}

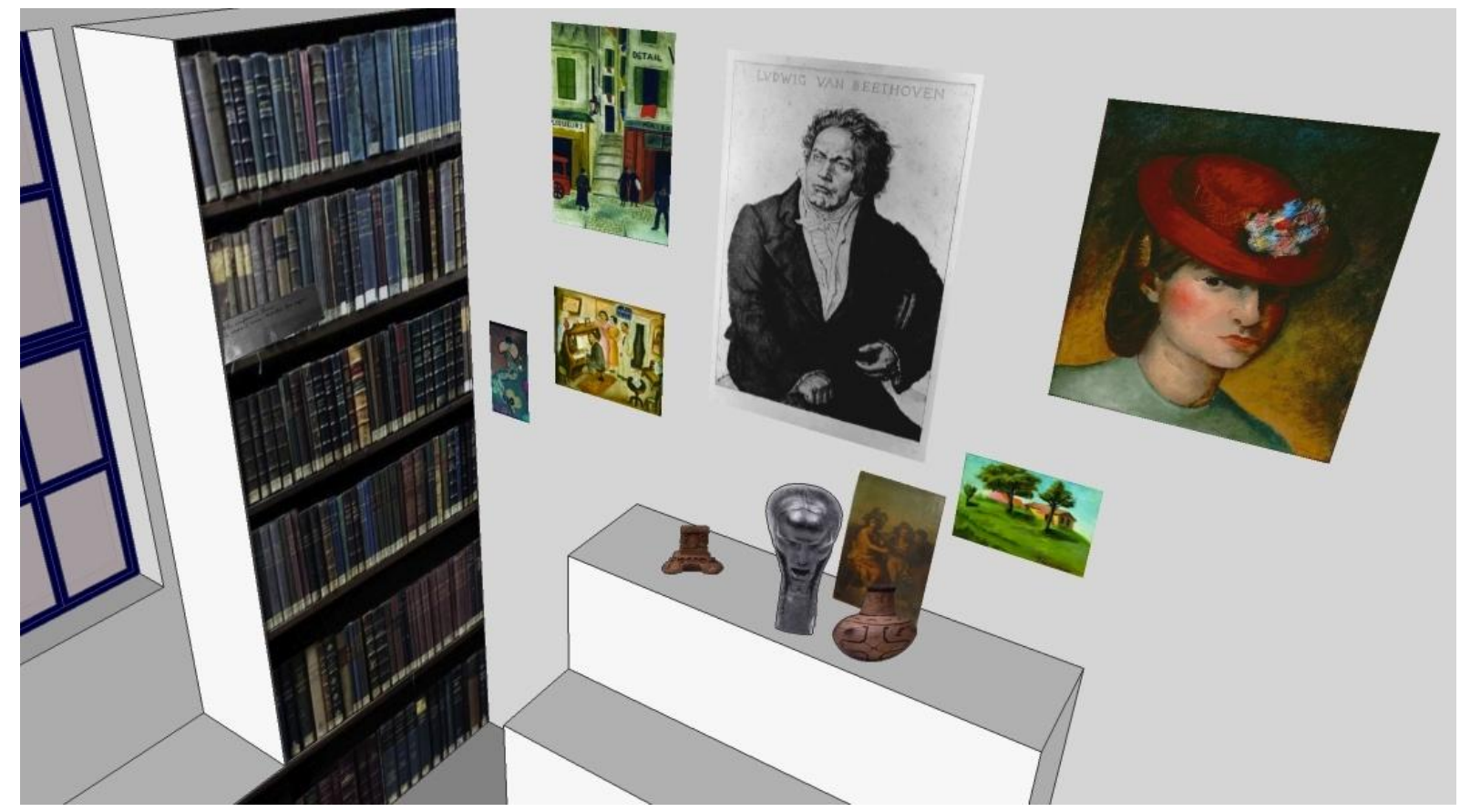

Imagem 32. Vista da saleta de piano.

Fonte: Maquete eletrônica da casa de Mário de Andrade. Camila Lacerda, 2012.

A sala de aula para o ensino de piano ficava à direita do vestíbulo, o que garantia a privacidade para a residência mesmo com a movimentação dos alunos. É interessante notar que é o único cômodo de toda a casa, em que uma das paredes possui pintura decorativa, justamente aquela em que estão as obras expostas, sem, contudo criar o mesmo efeito que o Pavilhão Modernista de Dona Olívia. Nesta sala, além das paredes forradas de estantes de

${ }^{17}$ BATISTA, Marta Rossetti. Centenários Modernistas I: Wilhelm Haarberg (1891 - 1986), op. cit..

${ }^{18}$ Mário de Andrade destinara para "concursos de desenhos coloridos a lápis de cor e de modelagem nos três Parques Infantis e na Biblioteca Infantil, tudo material e prêmios pagos do meu bolso. O gasto ficou em mais de 2:000\$000. M.”. Hoje, boa parte destes desenhos faz parte do Fundo Mário de Andrade. In: BATISTA, Marta Rossetti e LIMA, Yone Soares de. Coleção Mário de Andrade. Artes Plásticas. São Paulo: IEB USP, 1984, p. XXX. 
livros, há o piano de armário com dois candelabros laterais, ladeado por diversas obras de sua coleção de artes.

A começar com a Cabeça de Cristo de Brecheret, que se encontra centralizada bem acima do piano, juntamente com os seguintes objetos da coleção: pedestal em pedra, cujos dados sobre colheita, procedência e uso são desconhecidos, e bilha de índios do Peru, da década de 1920, feita em barro cozido e pintado, talvez colhido por Mário durante sua viagem ao Norte em 1927, possivelmente já eram “feitas 'para o mercado externo' às tribos, para venda" ${ }^{19}$. É possível observar outros objetos, contudo não compõem o conjunto que seguiu para o IEB. Logo acima, do piano, está a gravura em metal de Ludwig van Beethoven, cujo autor é Emil Orlik, o que faz referência direta ao universo musical que rodeia o poeta, seja pelo próprio instrumento, seja pela presença de um dos maiores compositores de música clássica. Mário de Andrade pagara $600 \$ 000$ (seiscentos mil-réis) por esta gravura, a Heuberger durante a exposição alemã de $1930^{20}$.
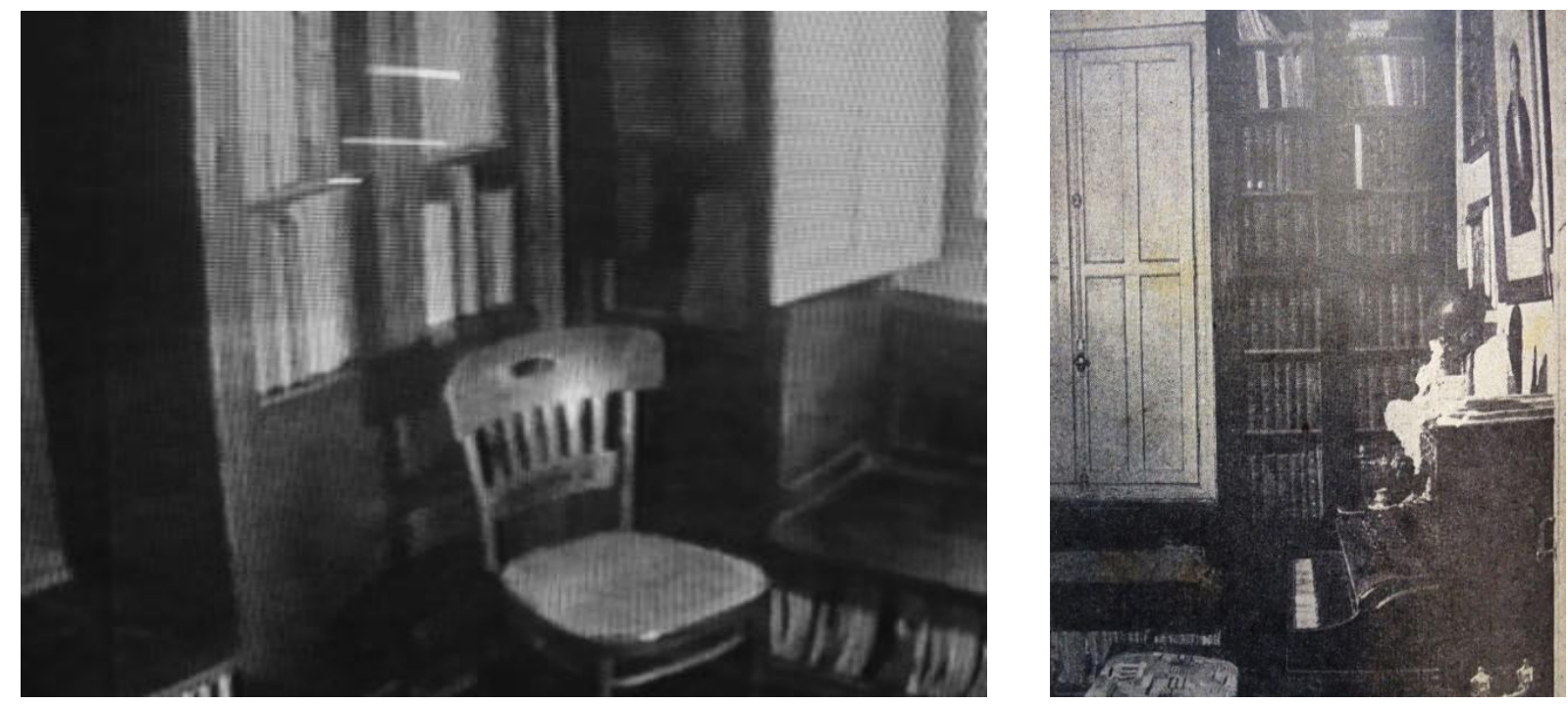

Imagem 33 e 34. Vistas da sala de música.

Fonte: Casa de Mário de Andrade. SARNO, Geraldo (dir.); FARKAS, Thomaz (fot.). São Paulo: IEB USP, 1968 Imagem 35. Sala de música - piano e obras de arte.

Fonte: MARTINS, Justino. Presença e Ausência de Mário de Andrade. Ed. Keffel (fotografias). Revista do Globo. Porto Alegre, 23 fev. 1946.

Neste arranjo, há a convivência entre diversas facetas de Mário de Andrade: professor e estudioso da música; participante do movimento modernista, em especial da Semana de Arte Moderna; escritor e poeta cuja linguagem fora modernizada justamente com esta escultura; colecionador interessado em obras que documentassem sua vivência; todos os aspectos a contribuir para a fusão dos três princípios fundamentais da realidade brasileira:

${ }^{19}$ BATISTA, Marta Rossetti. Coleção Mário de Andrade: religião e magia, música e dança, cotidiano. São Paulo: Editora da Universidade de São Paulo: Imprensa Oficial do Estado, 2004, p. 360.

${ }^{20}$ BATISTA, Marta Rossetti e LIMA, Yone Soares de. Coleção Mário de Andrade. Artes Plásticas. São Paulo: IEB USP, 1984, p. XXVII. 
"o direito permanente à pesquisa estética, a atualização da inteligência artística brasileira; e, a estabilização de uma consciência nacional" ${ }^{21}$.

Desde o início da formação da coleção de Mário de Andrade, estas duas obras estão presentes, uma faz parte de seus bronzes e águas-fortes, conforme vimos no Prefácio Interessantíssimo da coleção. Além destas, a sala ainda possui as seguintes obras: Colombina de Ignácio da Costa Ferreira Ferrignac, Nice de Joaquim do Rego Monteiro, Soirée de família de Noêmia Mourão, Mulher de chapéu vermelho de Ignês Maria Luísa Correia da Costa e Paisagem de Francisco Rebolo Gonsales. Com as imagens disponíveis, seja pela pouca definição da imagem do filme de 1968, seja pela não captura deste trecho do de 1955, ficou sem identificação uma obra à direita a Paisagem.
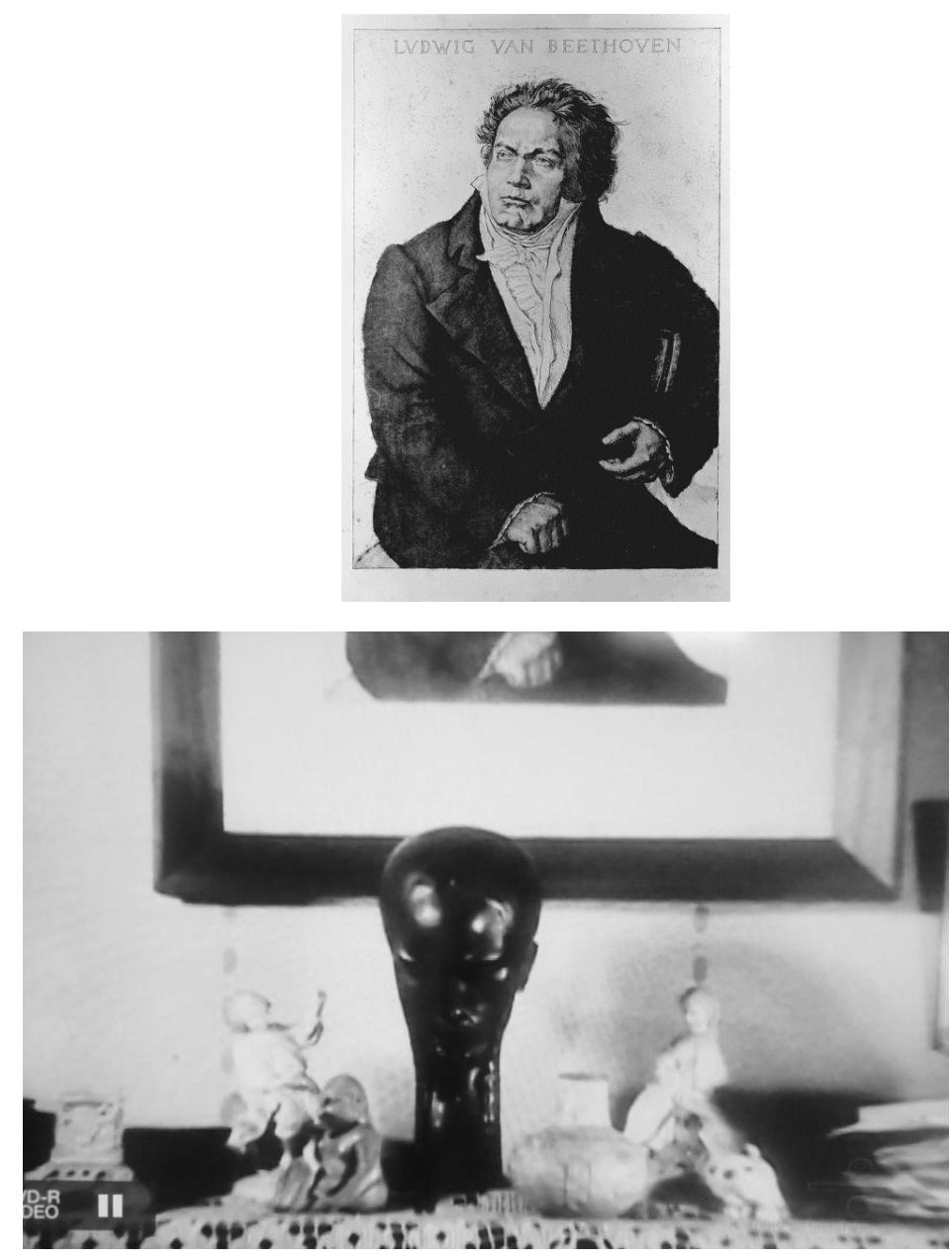

Imagem 36. Ludwig van Beethoven de ORLIK, Emil, s.d., gravura em metal sobre papel, $57.0 \times 38.5 \mathrm{~cm}$.

Fonte: Coleção Mário de Andrade - Coleção de Artes Visuais do Instituto de Estudos Brasileiros da USP.

Imagem 37. Cabeça de Cristo de Brecheret, sob o piano da sala de música. Acima Ludwig van Beethoven.

Fonte: Casa de Mário de Andrade. SARNO, Geraldo (dir.); FARKAS, Thomaz (fot.). São Paulo: IEB USP, 1968.

${ }^{21}$ ANDRADE, Mário de. O movimento modernista, op. cit., p. 266. 

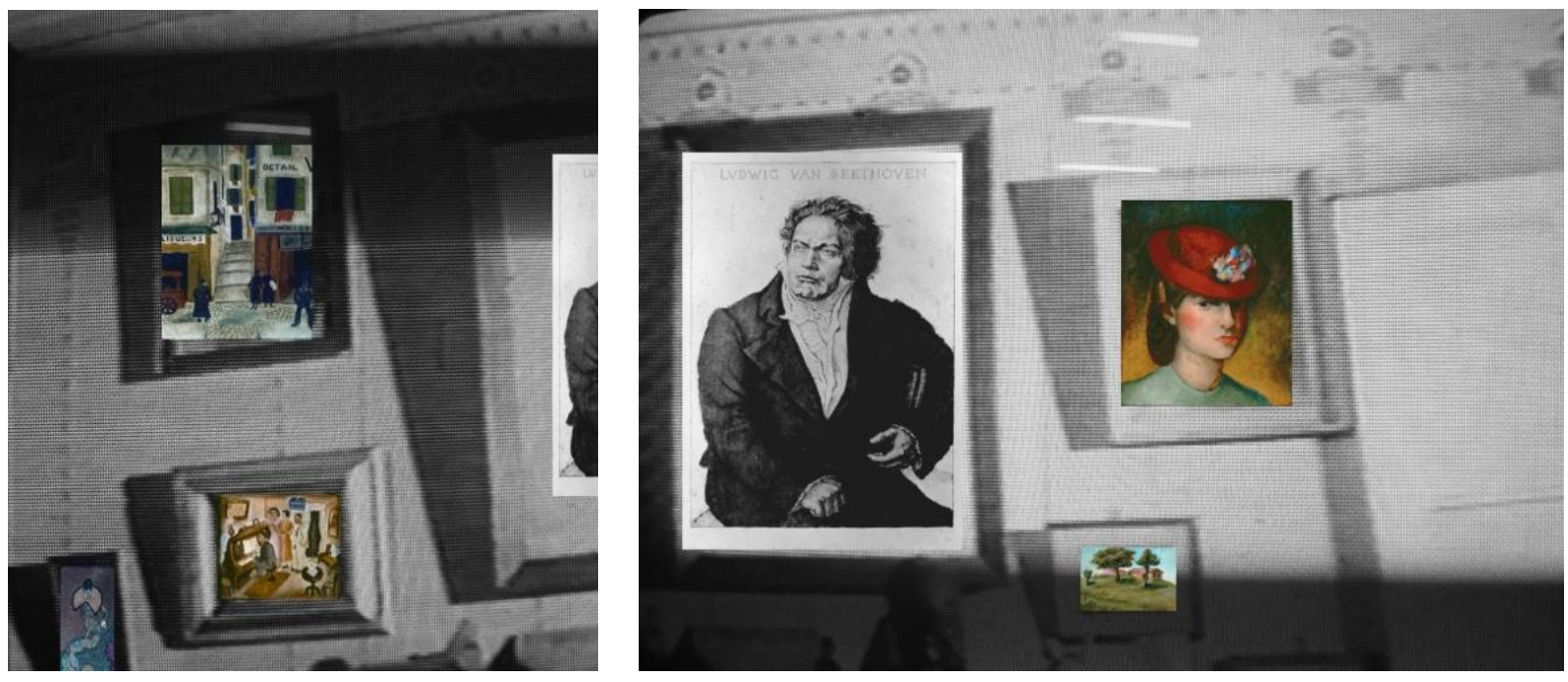

Imagem 38. Vista das obras expostas, próximas ao piano, na sala para ensino de música.

Fonte: Casa de Mário de Andrade. SARNO, Geraldo (dir.); FARKAS, Thomaz (fot.). São Paulo: IEB USP, 1968.

Joaquim do Rego Monteiro, irmão mais moço de Vicente do Rego Monteiro, vivera boa parte de sua vida em Paris, local em que faleceu no ano de 1932. Segundo as pesquisadoras Marta Batista e Yone de Lima, "Em 1924 esteve no Brasil e fez uma individual em São Paulo, quando provavelmente expôs o óleo Nice, tão 'parisiense' no enfoque e no colorido, com seus cinzas transparentes nos quais distribuiu pequenas áreas de cor vibrante" 22. Possivelmente, fora nesta ocasião que esta obra entrou para a coleção de Mário de Andrade.

Ferrignac (1892-1958) era ilustrador, tal como seu companheiro Di Cavalcanti, e expôs na Semana de Arte Moderna uma obra intitulada Natureza dadaísta, hoje desconhecida. A obra da coleção de Mário de Andrade, Colombina, é "um desenho decorativo tratado com humor, a cor espalhada por borrifação, aliada à 'ousadia' de uma colagem muito discreta" 23 .

Noêmia Mourão participara dos ateliês livres do Clube dos Artistas Modernos, tendo aula com Di Cavalcanti, com quem se casaria. A obra Soirée de família compõe um ambiente musical, o qual poderia ser a própria sala de Mário de Andrade e que despertara seu interesse. Em papel timbrado da Revista Acadêmica, Murilo Miranda informa o valor da pintura $500 \$ 000^{24}$, que foram enviados, o que leva Mário de Andrade solicitar recibo ${ }^{25}$.

Já Ignês Correia da Costa está ligada à Candido Portinari, do qual fora auxiliar, assim como outros artistas presentes na coleção Mário de Andrade, tal como Burle-Marx e Enrico Bianco. Possivelmente, a ligação com Portinari é que fez o colecionador integrar esta obra a sua coleção, pois, se trata de um dos alunos do autor de Retirantes.

Por fim, nesta sala, a obra Paisagem de Francisco Rebollo, que talvez seja da época do Grupo Santa Helena. Esta obra fixa "uma casinha, três árvores, ligadas por céu e terra

${ }^{22}$ BATISTA, Marta Rossetti e LIMA, Yone Soares de, op. cit., p. XXXIX.

${ }^{23}$ Ibidem, p. XXXVI.

${ }^{24}$ Correspondência de Murilo Miranda a Mário de Andrade. Rio de Janeiro, [ant. 12 mar. 1936], pertencente ao Fundo Mário de Andrade, código de referência: MA-C-CPL4999.

${ }^{25}$ Correspondência de Mário de Andrade a Murilo Miranda. São Paulo, 12 mar. 1936, pertencente ao Fundo Mário de Andrade, código de referência: MA-C-CPR364. 
pincelados em nuances, com o movimento do pincel mais visível e o óleo espesso" ${ }^{26}$. A partir do texto Esta Paulista Família, Mário de Andrade acompanha e aposta na pintura de Rebolo pelas "suas qualidades técnicas muito seguras, sabe revelar uma alma já bem caracterizada, suave e cheia de delicada poesia" ${ }^{27}$.
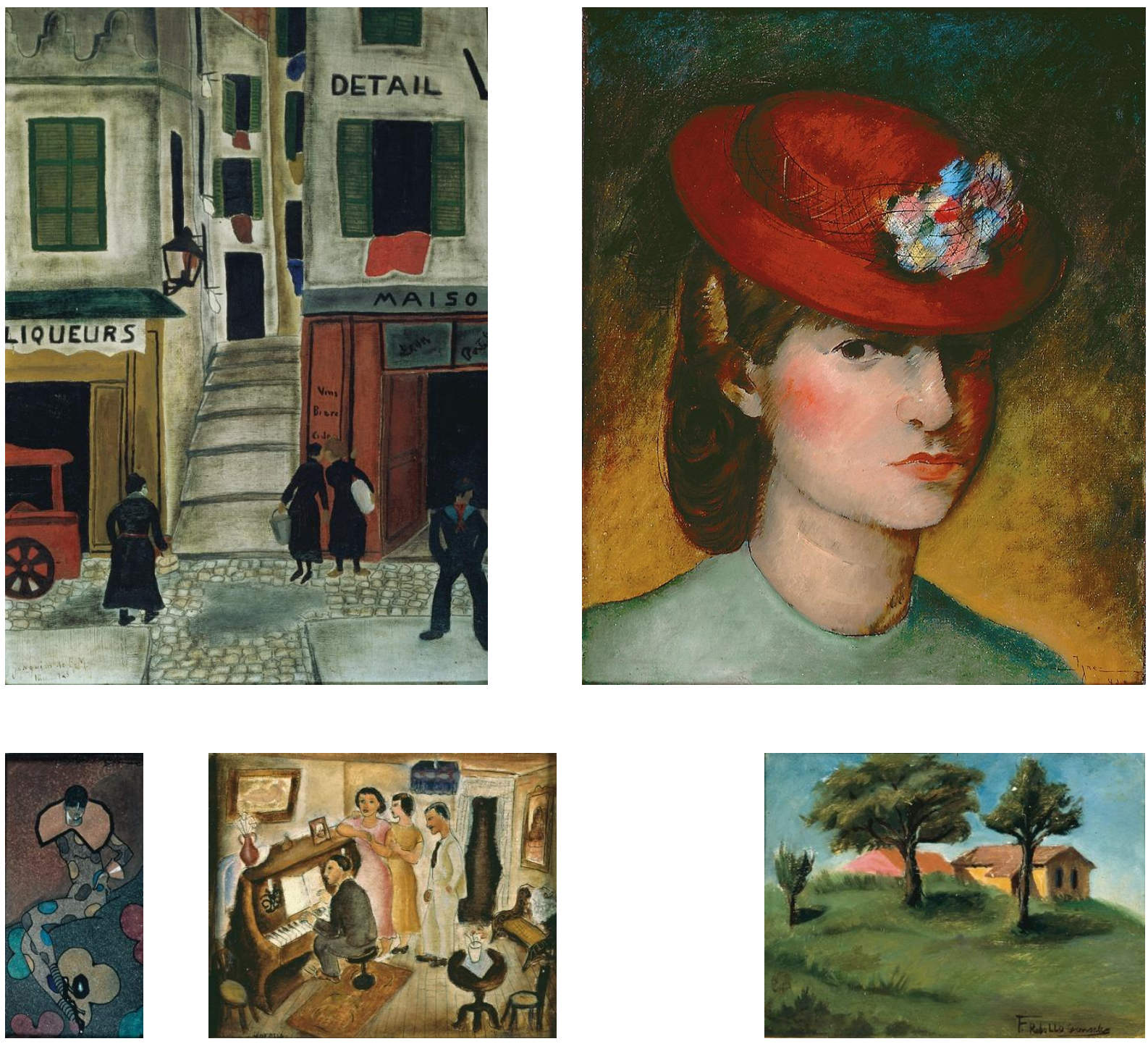

Imagem 39. MONTEIRO, Joaquim do Rego. Nice, 1923. óleo sobre madeira, $46.2 \times 33.2 \mathrm{~cm}$.

Imagem 40. FERRIGNAC, Ignácio da Costa Ferreira. Colombina, s.d. nanquim, aquarela e colagem sobre papel, $28.0 \times 13.8 \mathrm{~cm}$.

Imagem 41. MOURÃO, Noêmia. Soirée de família, 1934/35 c. óleo sobre tela, $21.8 \times 27.0 \mathrm{~cm}$.

Imagem 42. CORREIA DA COSTA, Ignês Maria Luísa. Mulher de chapéu vermelho, 1938. óleo sobre tela, $41.5 \mathrm{X}$ $34.0 \mathrm{~cm}$.

Imagem 43. REBOLO Gonsales, Francisco. Paisagem, s.d. óleo sobre cartão rígido, $13.0 \times 17.5 \mathrm{~cm}$.

Fonte: Coleção Mário de Andrade - Coleção de Artes Visuais do Instituto de Estudos Brasileiros da USP.

${ }^{26}$ BATISTA, Marta Rossetti e LIMA, Yone Soares de, op. cit., p. LVI. Infelizmente, esta obra fora roubada em dezembro de 1983.

${ }^{27}$ ANDRADE, Mário de. Esta Paulista Família. In: MOTTA, Flávio. A Família Artística Paulista. Revista do Instituto de Estudos Brasileiros, São Paulo, 10: 137-175, 1971, p. 156. 
O conjunto de obras desta saleta possui pouca unidade visual, contudo observa-se a alusão à música, seja por meio da imagem de Beethoven, seja pela Soirée de família. Além disso, Mário de Andrade constrói uma imagem pública da sua participação no modernismo com a exposição da Cabeça de Cristo, parecendo coroar sua atividade como professor de piano, e, também, o catalisador para seu primeiro livro modernista Paulicéia Desvairada. É ainda dos tempos heróicos, a Colombina que mesmo não participando da mostra, representa um dos artistas que ali expôs. Nessa mesma linha, seriam as obras Nice, da orgia intelectual, Paisagem, já da fase de construção em que o colecionador prezava o bem-fazer artístico, e Mulher de chapéu vermelho que remete possivelmente a relação de Cândido Portinari, considerado por Mário como um dos melhores artistas brasileiros, guardando-o para exclusivamente para seu estúdio, como se verá mais adiante. Dessa forma, as obras perpassam os diversos tempos modernistas, contudo não são representados pelas melhores obras da coleção de cada um dos períodos, salvo a exceção da Cabeça de Cristo, como a dar uma leve pincelada pelas transformações que a arte brasileira passara.

Em relação à manutenção das obras no mesmo lugar, desde a morte de Mário de Andrade até sua ida para a Universidade, é importante ressaltar o acréscimo de objetos acima do piano. Infelizmente, a qualidade da imagem dificulta a identificação de todos eles, o único passível de reconhecimento é uma pintura a óleo sobre madeira, Cópia de Los Borrachos, de Goya, sem identificação de autoria. Esta obra possui a seguinte dedicatória "Al caro Maestro Romeo Pereira... [ilegível] 26/10/1916".

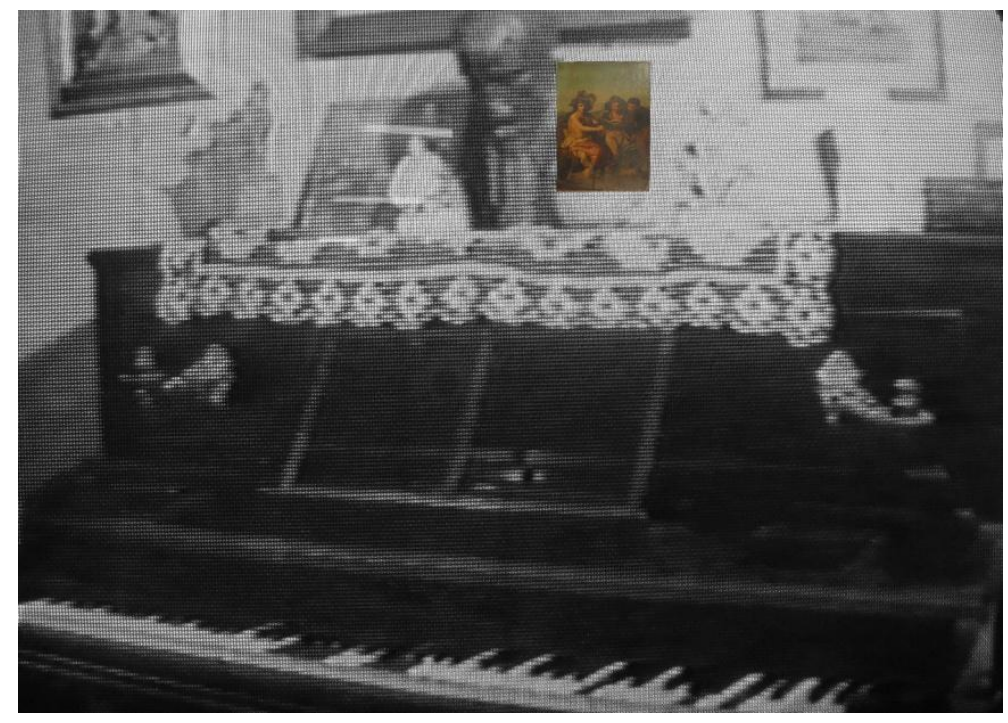

Imagem 44. Acréscimo de obras acima do piano. Cópia de Los Borrachos de Goya, sem identificação de autoria, s.d. óleo sobre madeira, $25.1 \times 15.8 \mathrm{~cm}$.

Fonte: Casa de Mário de Andrade. SARNO, Geraldo (dir.); FARKAS, Thomaz (fot.). São Paulo: IEB USP, 1968. 


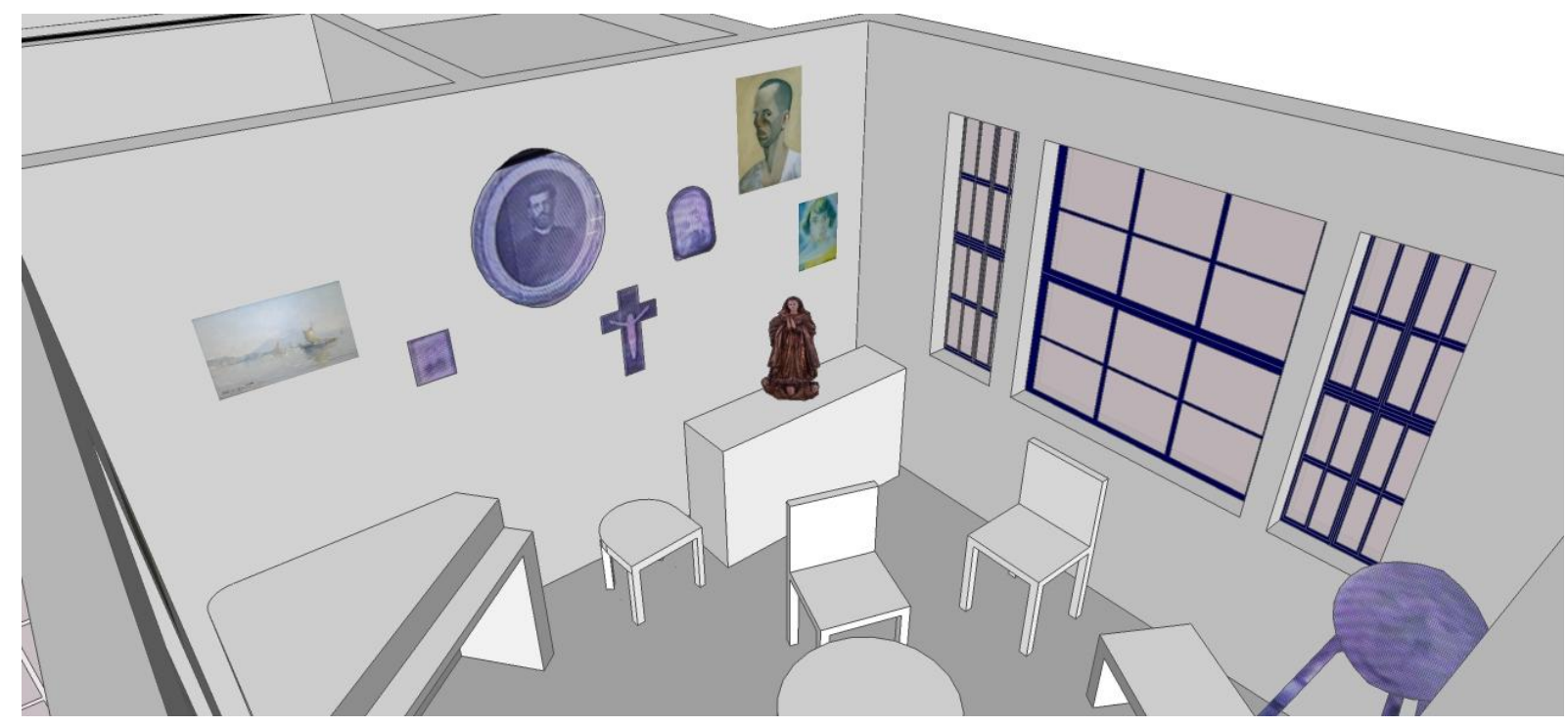

Imagem 45. Vista da sala de visitas 1.

Fonte: Maquete eletrônica da casa de Mário de Andrade. Camila Lacerda, 2012.

A sala de visitas da casa de Mário de Andrade possui um grande número de lugares para se sentar: sofás, poltronas, cadeiras, banquetas, como a rodear uma pequena mesa de centro redonda; no entanto, o foco da sala é o piano de meia cauda, ao qual tudo se converge e sugere um ambiente montado para acolher inúmeros visitantes.
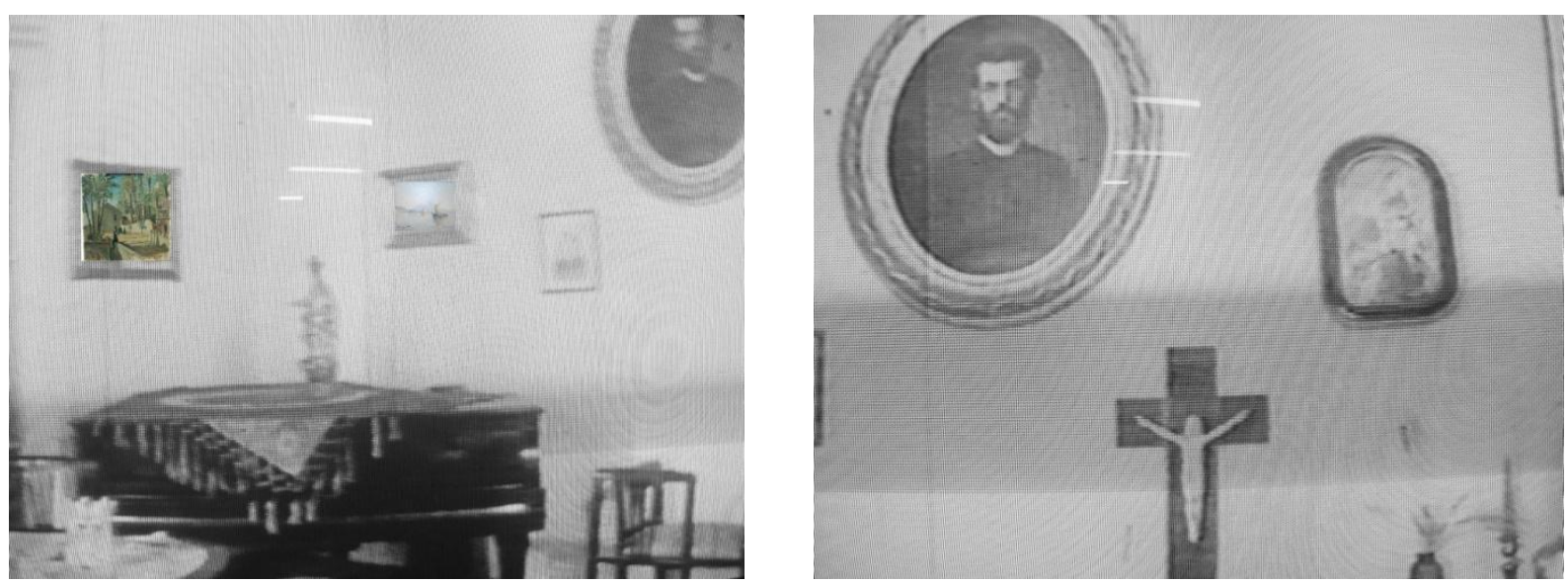

Imagem 46 e 47. Sala de visita com piano como focal e paredes adjacentes.

Fonte: Casa de Mário de Andrade. SARNO, Geraldo (dir.); FARKAS, Thomaz (fot.). São Paulo: IEB USP, 1968.

Iniciando-se pela direita da porta de acesso, sobre o piano encontra-se a obra Paisagem - Canto de rua com palmeiras, de Paulo Cláudio Rossi Osir, datada de 1927. Este artista paulista, com ascendência italiana, amigo de Portinari e criador da Firma de Azulejos Osirarte, que executa obras ressaltáveis, cursou arquitetura em Bolonha, formava a trinca de 
"estrangeiros em São Paulo com legítima técnica de pintar" ${ }^{28}$ - em primeiro lugar Lasar Segall, depois Vittorio Gobbis juntamente com Rossi Osir. Para Mário de Andrade, todos vieram "mansamente destruir tanto o nosso analfabetismo pictórico como o aprimorismo sentimental dos 'casos'" 29 . Após sua volta ao Brasil, realizou exposição em fins de 1927, da qual possivelmente tenha participado a tela Paisagem - canto de rua com palmeiras, imagem "dos recantos europeus pintados pelos bolsistas brasileiros acadêmicos" 30 .
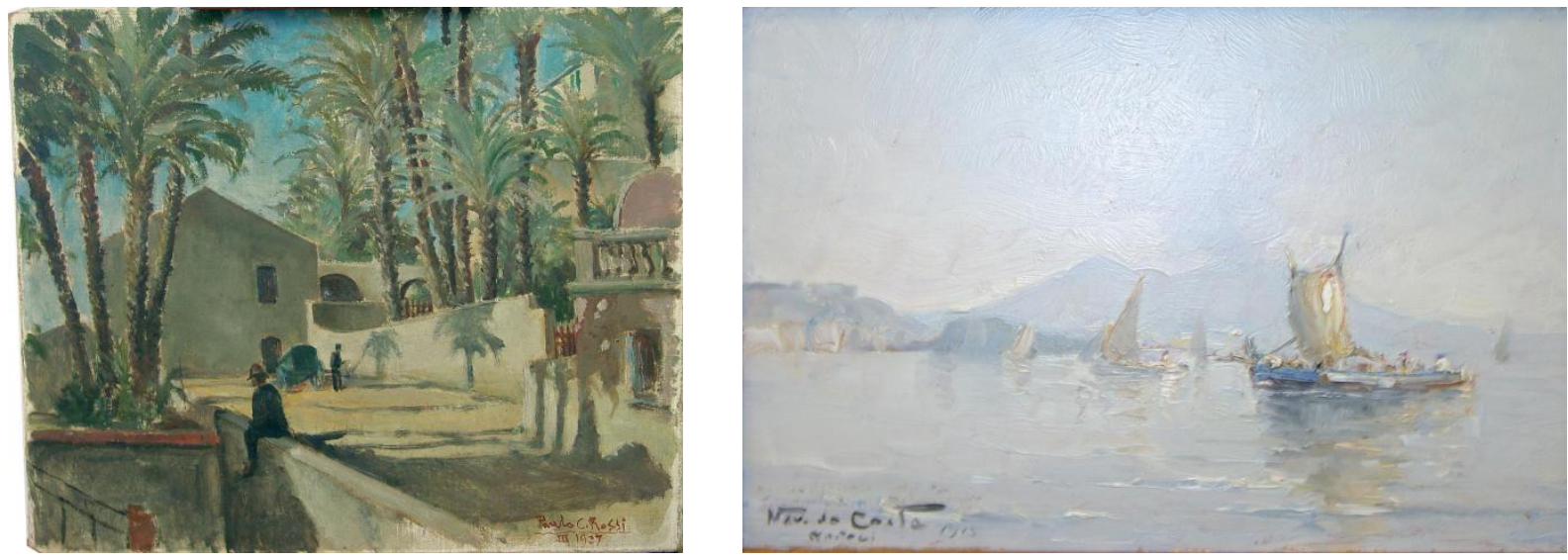

Imagem 48 e 49. Paisagem - canto de rua com palmeiras de ROSSI OSIR, Paulo Cláudio, 1927, óleo sobre tela, 38.8 X $46.5 \mathrm{~cm}$ e Marinha de COSTA, Mário Navarro da, 1915, óleo sobre madeira, 20.3 X $30.7 \mathrm{~cm}$.

Fonte: Coleção Mário de Andrade - Coleção de Artes Visuais do Instituto de Estudos Brasileiros da USP.

Seguindo pela direita, ao lado dessa paisagem, há a Marinha do pintor-diplomata Mário Navarro da Costa, que provavelmente entrou na coleção em maio de 1944, quando Mário de Andrade adquirira também algumas obras do maestro Artur Pereira para ajudá-lo. Possivelmente o maestro trouxera de seu estágio na Itália ${ }^{31}$. A imagem é de Nápoles pintada, em 1915, com tintas claras em pinceladas soltas, demonstrando a popularização do impressionismo, já aceito pelo acadêmico ${ }^{32}$.

Juntamente com a exposição da sua coleção de artes ao olhar, há imagens sacras, crucifixo e santo, e também retratos de família, por exemplo, o realizado pelo pintor alemão Pfaff, possivelmente Johann Fredrich, retratista do século XIX, que pintara um parente distante de Mário, cuja morte prematura interrompera o que seria um futuro promissor.

${ }^{28}$ ANDRADE, Mário de. Esta Paulista Família. In: MOTTA, Flávio. A Família Artística Paulista. Revista do Instituto de Estudos Brasileiros, São Paulo, 10: 137-175, 1971, p. 155.

${ }^{29}$ Ibidem.

${ }^{30}$ BATISTA, Marta Rossetti e LIMA, Yone Soares de. Coleção Mário de Andrade. Artes Plásticas. São Paulo: IEB USP, 1984, p. XLVIII.

31 Ibidem, p. XXXI.

${ }^{32}$ Ibidem, p. XXXIII. 

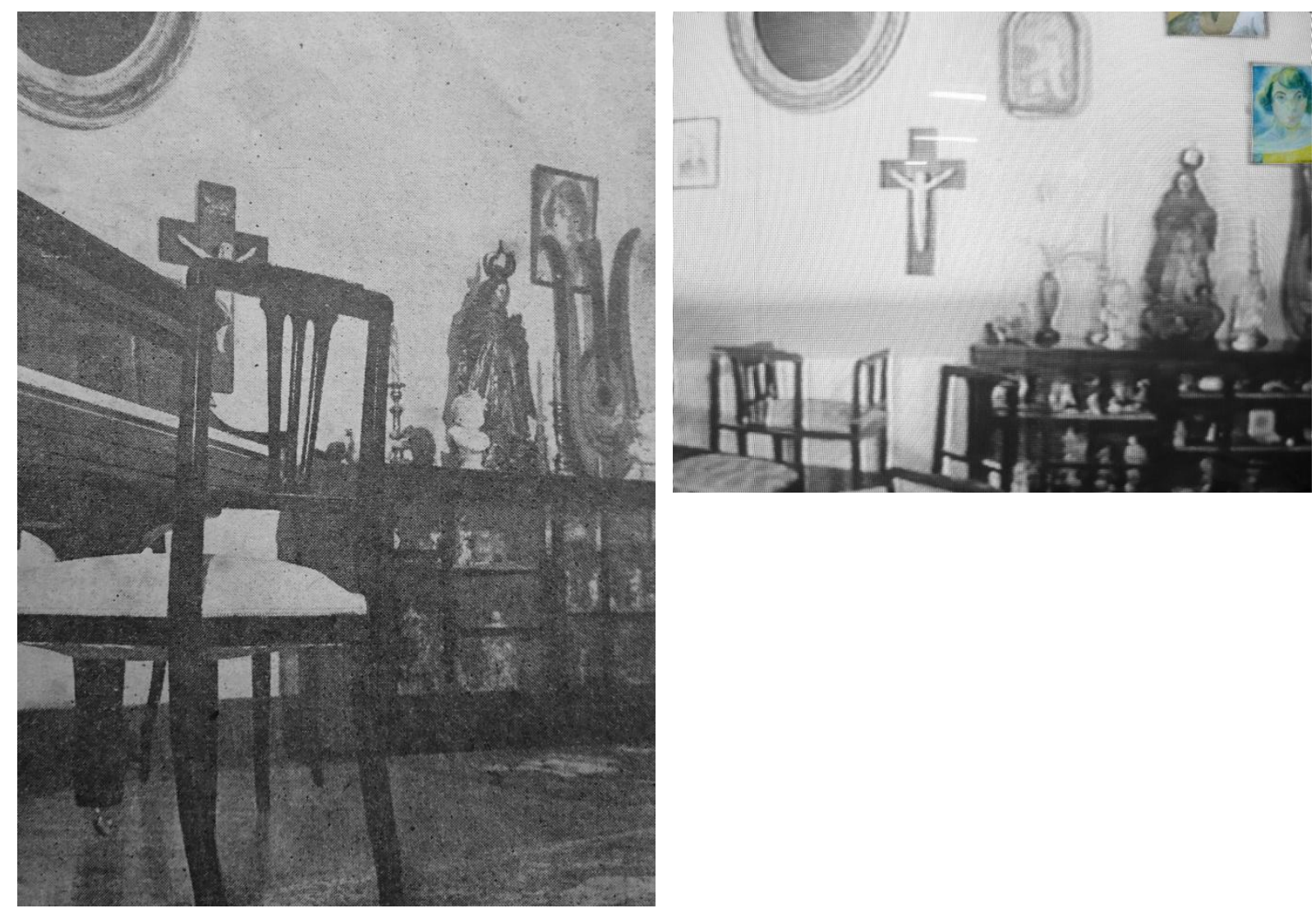

Imagem 50 e 51. Destaque para estante de objetos dos mais variados, santos católicos, ex-votos, objetos indígenas, de culto afro-brasileiro, cuias, figas, bois, entre outros.

Fonte: MARTINS, Justino. Presença e Ausência de Mário de Andrade. Ed. Keffel (fotografias). Revista do Globo. Porto Alegre, 23 fev. 1946.

Fonte: Casa de Mário de Andrade. SARNO, Geraldo (dir.); FARKAS, Thomaz (fot.). São Paulo: IEB USP, 1968.

De acordo com o vídeo de 1968, a obra seguinte seria o Auto-retrato de José Pancetti, contudo, na fotografia da reportagem da Revista do Globo, esta obra não se encontra lá, possivelmente uma pequena alteração na disposição das obras. É interessante notar que, mesmo sem ser a própria mão de Mário de Andrade, há uma preocupação em deixar nessa mesma parede uma série de retratos, tanto os familiares, quanto pinturas de sua coleção.

Pancetti convive com o Núcleo Bernardelli do Rio de Janeiro, análogo ao Grupo Santa Helena de São Paulo, nos quais imigrantes agregavam-se com uma visão mais humanizada, distante da aristocracia dos primeiros tempos do modernismo. $\mathrm{O}$ artista em contato com as lições de Bruno Lechowski, artista polonês e ligado ao Núcleo, trouxera para sua obra a "estrutura de suas telas, a geometrização simplificadora e organizadora" ${ }^{33}$. Possivelmente, o interesse de Mário de Andrade seja justamente as possibilidades inerentes da manifestação artística, qual seja ser "essencialmente humana, se não pela sua finalidade, pelo menos pela sua maneira de operar" ${ }^{34}$.

Já o Auto-retrato de Anita remete aos momentos posteriores à Semana de Arte Moderna, quando o grupo dos cinco se formara com: os escritores, Menotti del Picchia,

\footnotetext{
33 Ibidem, p. LII.

${ }^{34}$ ANDRADE, Mário de. $\mathrm{O}$ artista e o artesão, op. cit.
} 
Mário e Oswald de Andrade e as pintoras Tarsila do Amaral e Anita Malfatti. Eram reuniões que em que se declamava poesias, ouvia-se música tendo Mário e Tarsila ao piano, e pintava-se, tal qual retratado no desenho 0 grupo dos cinco, de Anita. Em outubro de 1922, as pintoras realizaram sessão de retratos, tanto o de Mário quanto os seus próprios, todos em lápis pastel ${ }^{35}$.
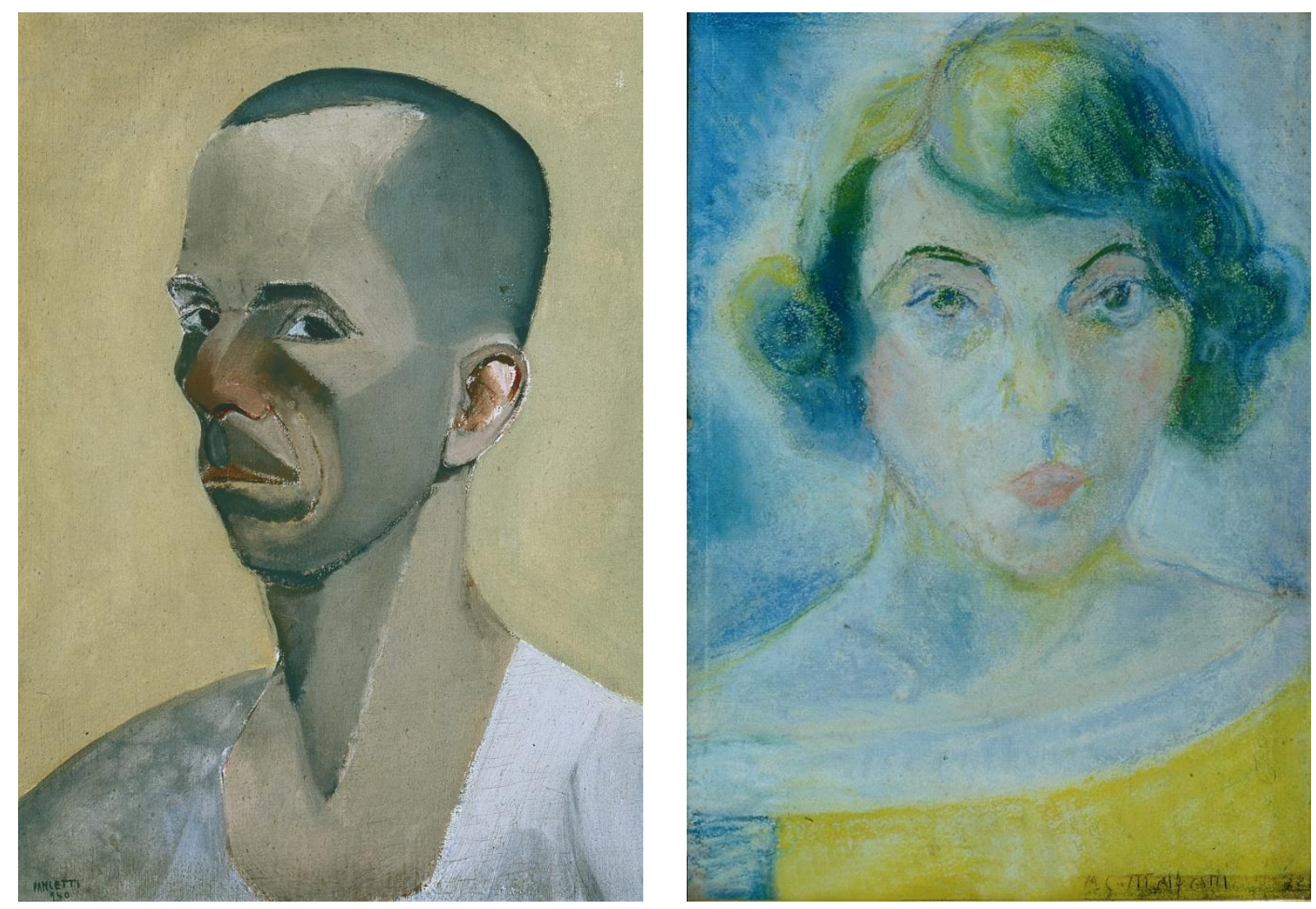

Imagem 52 e 53. Auto-retrato de PANCETTI, José (Giuseppe Gianinni), 1940, óleo sobre tela, $49.2 \times 38.2 \mathrm{~cm}$ e Auto-retrato de MALFATTI, ANITA Catarina, 1922, pastel sobre cartão rígido, $36.5 \times 25.5 \mathrm{~cm}$.

Fonte: Coleção Mário de Andrade - Coleção de Artes Visuais do Instituto de Estudos Brasileiros da USP.

Após uma parede dos três janelas, na fachada da casa, há um cavalete em que se apóia, provavelmente, uma imagem católica, sendo apenas uma suposição, pois as fontes documentais não permitem precisar qual seria esta figura. Contudo, é interessante que o uso do cavalete nas salas de visita faz parte das diretrizes do manual para o lar doméstico, de 1898 de Vera Cleser, denotando "a importância dos objetos como estimuladores dos sentidos" 36 .

\footnotetext{
${ }^{35}$ BATISTA, Marta Rossetti e LIMA, Yone Soares de, p. XXXVII.

${ }^{36}$ Conforme, CARVALHO, Vânia Carneiro de, op. cit., p. 156 e 158.
} 


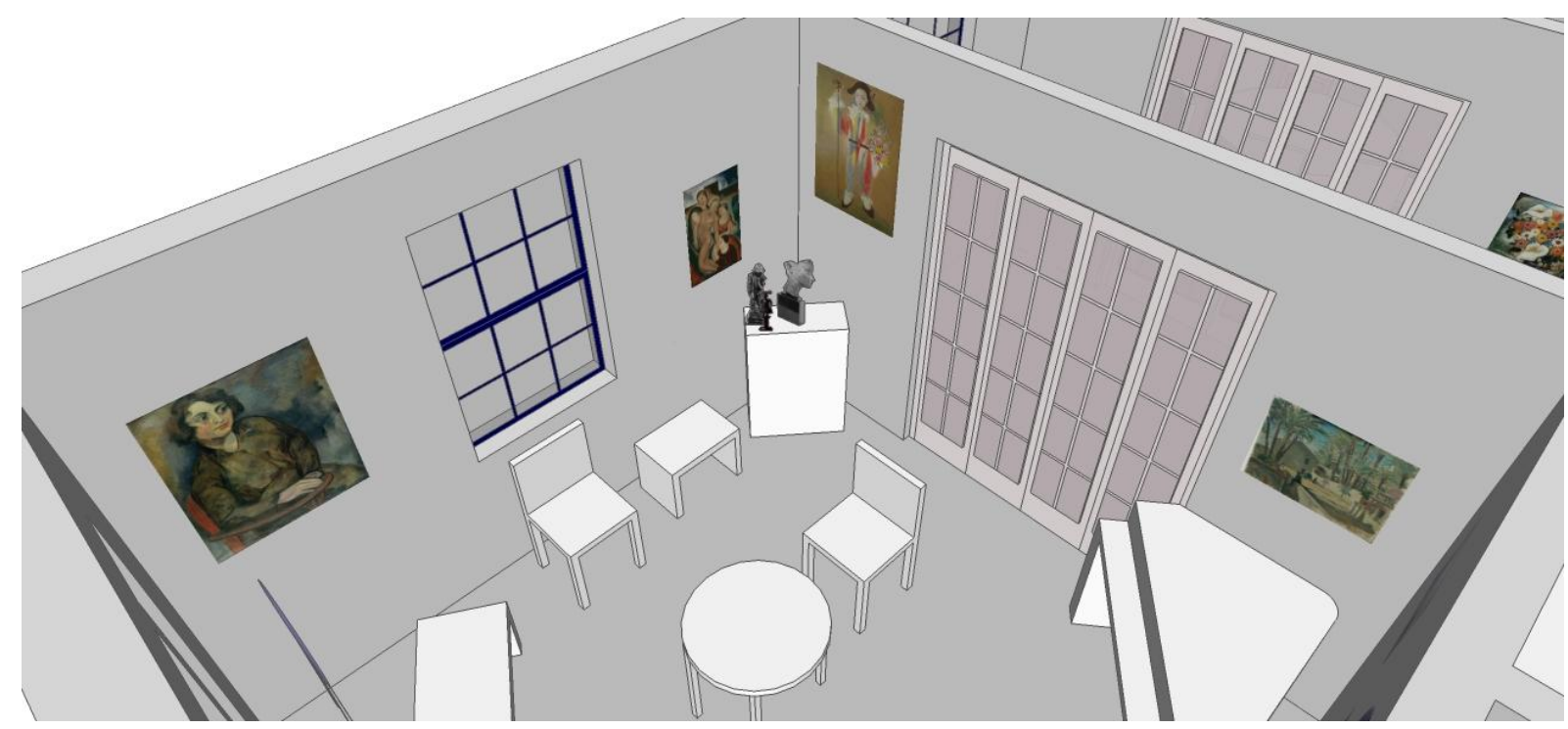

Imagem 54. Vista da sala de visitas 2.

Fonte: Maquete eletrônica da casa de Mário de Andrade. Camila Lacerda, 2012.
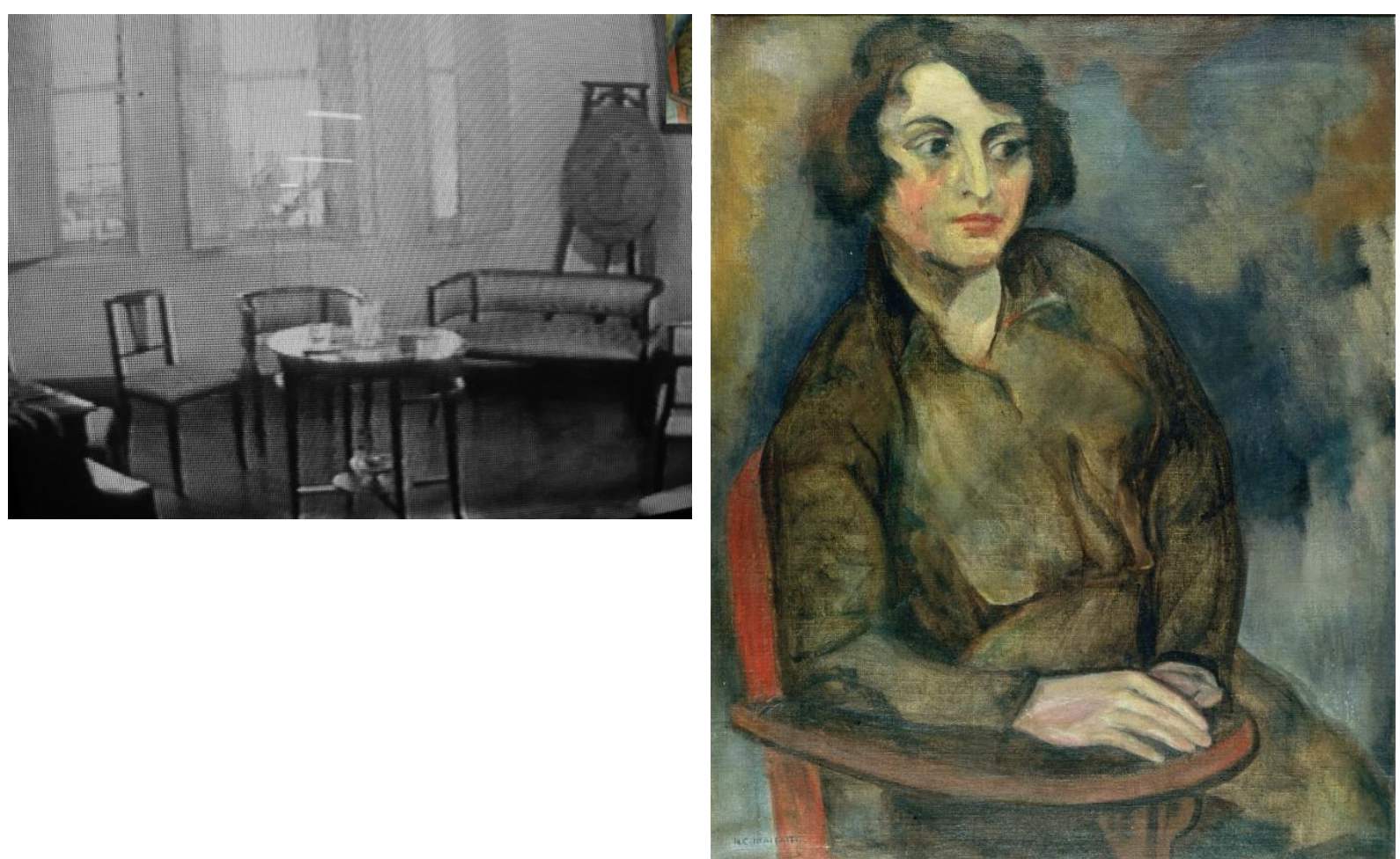

Imagem 55. Cavalete no canto da sala e no canto superior direito A estudante russa, de Anita Malfatti. Fonte: Casa de Mário de Andrade. SARNO, Geraldo (dir.); FARKAS, Thomaz (fot.). São Paulo: IEB USP, 1968. Imagem 56. A estudante russa de MALFATTI, ANITA Catarina, óleo sobre tela, 1915 c., 76.0 X $61.0 \mathrm{~cm}$. Fonte: Coleção Mário de Andrade - Coleção de Artes Visuais do Instituto de Estudos Brasileiros da USP. 
A estudante russa entrara na coleção de Mário ,em 5 de dezembro de 1935, quando a comprou da artista, por 3:000\$000 (três contos de réis) ${ }^{37}$. Esta obra fora pintada durante sua estada na Independent School de Homer Boss, nos Estados Unidos, entre 1915 e 1916. É neste momento que a Anita Malfatti amplia seu domínio da cor, neste caso a tinta é bastante diluída permitindo aparecer a textura da tela. A composição da figura feminina sentada em uma carteira, com "postura 'à vontade', a mão uma sobre a outra reforçam neste 'hino à raça russa' (termos de Mário de Andrade) as características de um autoretrato" ${ }^{38}$. Compõe, juntamente com outras obras da coleção de Mário, O homem amarelo e 0 japonês, a emblemática exposição individual de 1917, retornando à baila durante a Semana de Arte Moderna.
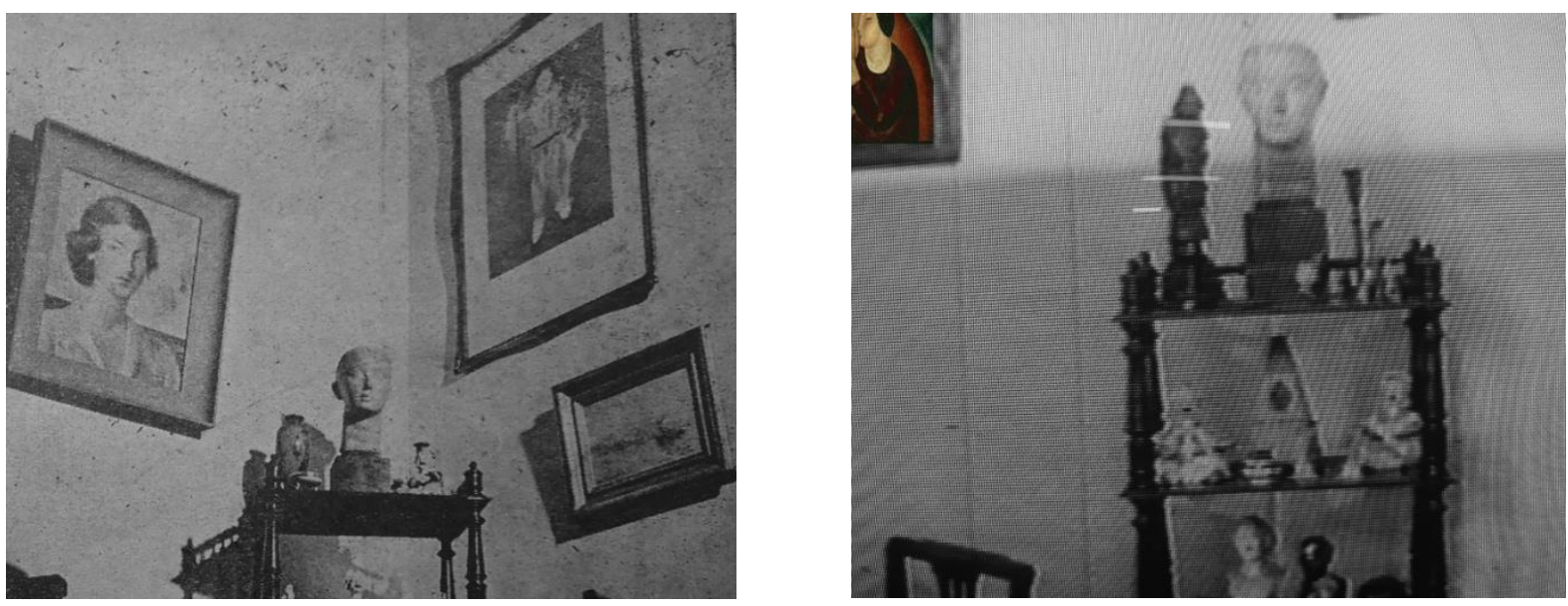

Imagem 57 e 58. Disposição da coleção e estante em um dos cantos da sala de visitas.

Fonte: MARTINS, Justino. Presença e Ausência de Mário de Andrade. Ed. Keffel (fotografias). Revista do Globo. Porto Alegre, 23 fev. 1946.

Fonte: Casa de Mário de Andrade. SARNO, Geraldo (dir.); FARKAS, Thomaz (fot.). São Paulo: IEB USP, 1968.

Ao se comparar as duas imagens, nota-se a troca do retrato à esquerda, que não integra a coleção do IEB nem se verificou qualquer referência, pela Descida da cruz de Antônio Gomide. Além disso, a Marinha de Navarro da Costa fora transferida para outro lado da sala, como se viu anteriormente; já em relação à estante, muitos objetos foram trocados, na qual foi acrescentada a escultura $O$ jornaleiro, de Ricardo Cipicchia e o Oxê de Xango, proveniente do culto afro-brasileiro. As permanências são a escultura Rosto feminino de Victor Brecheret e a gravura Arlequim atribuída a Pablo Picasso.

A escultura $O$ jornaleiro de Ricardo Cipicchia foi solucionado plasticamente com movimento, o que torna a obra fluída, a ponto da sua matéria quase chegar a derreter como parafina. Esta mesma temática do jornaleiro foi utilizada em outra escultura, $O$ engraxate $e$ o jornaleiro, também denominada Contando a féria, que se encontra na Praça João Mendes, na região central de São Paulo. A composição do jornaleiro, ao lado do menino engraxate, foi fundida em bronze e apresenta as mesmas soluções como chapéu, jornal embaixo do braço, roupas em várias camadas, calça erguida até a canela, pés descalços. Porém, o efeito plástico

\footnotetext{
${ }^{37}$ BATISTA, Marta Rossetti e LIMA, Yone Soares de, p. XXVIII.

${ }^{38}$ Ibidem, p. XXXIV.
} 
é distinto tendo em vista o material e técnica empregados, talvez seja a representação do homem brasileiro ligado ao trabalho.

Colocadas lado a lado, observa-se que ambas, mesmo com dimensões bem distintas, uma de aproximadamente $33 \mathrm{~cm}$ de altura e outra nas proporções humanas, são monumentais, fazendo parte da escala urbana. A datação ainda imprecisa e o levantamento documental ainda por fazer deixam a questão: seria a mão de Mário de Andrade guiando as escolhas das esculturas públicas da Paulicéia?
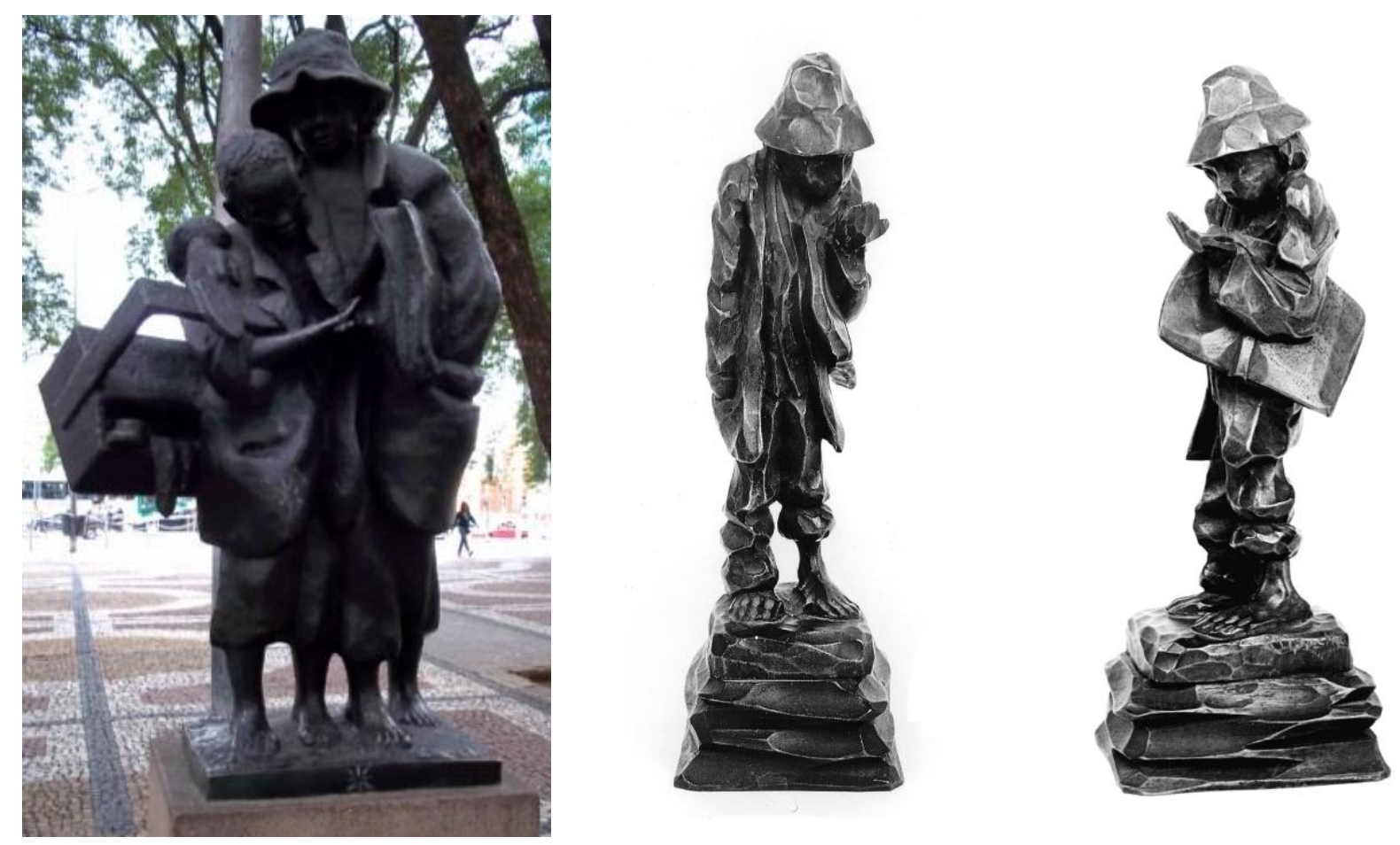

Imagem 59. O engraxate e o jornaleiro, ou Contando a féria, bronze.

Fonte: <http://www.monumentos.art.br/monumento/contando_a_feria_ou_o_engraixate_e_o_jornaleiro >. Acesso em 25 jul. 2011.

Imagem 60. O jornaleiro, CIPICCHIA, Ricardo, s.d., madeira, $35.5 \times 10.5 \mathrm{~cm}$.

Fonte: Coleção Mário de Andrade - Coleção de Artes Visuais do Instituto de Estudos Brasileiros da USP. 
Mesmo incerta a composição mistura esculturas de artistas reconhecidos com o orixá Xangô, da cultura ioruba. O conjunto revela o sincretismo de Mário de Andrade, tanto pelas diversas proveniências dos objetos culturais, quanto pelo entendimento da cultura por um viés que valorize as manifestações humanas, sejam elas eruditas ou populares. A execução elaborada com requinte plástico, faz com que a figura se pareça com um objeto artístico, possivelmente fora o resultado da encomenda que Luiz Saia a Augusto, interno do Hospital Psiquiátrico Juliano Moreira, em João Pessoa ${ }^{39}$. Trata-se de um momento em que o interesse em renovar as estruturas legadas da tradição leva a tais artistas e às crianças.

Imagem 61. Oxê de Xangô, Paraíba (João Pessoa), 1938, escultura em madeira polida, $22.9 \times 6.2 \times 6.2 \mathrm{~cm}$.

Fonte: Coleção Mário de Andrade - Coleção de Artes Visuais do Instituto de Estudos Brasileiros da USP.

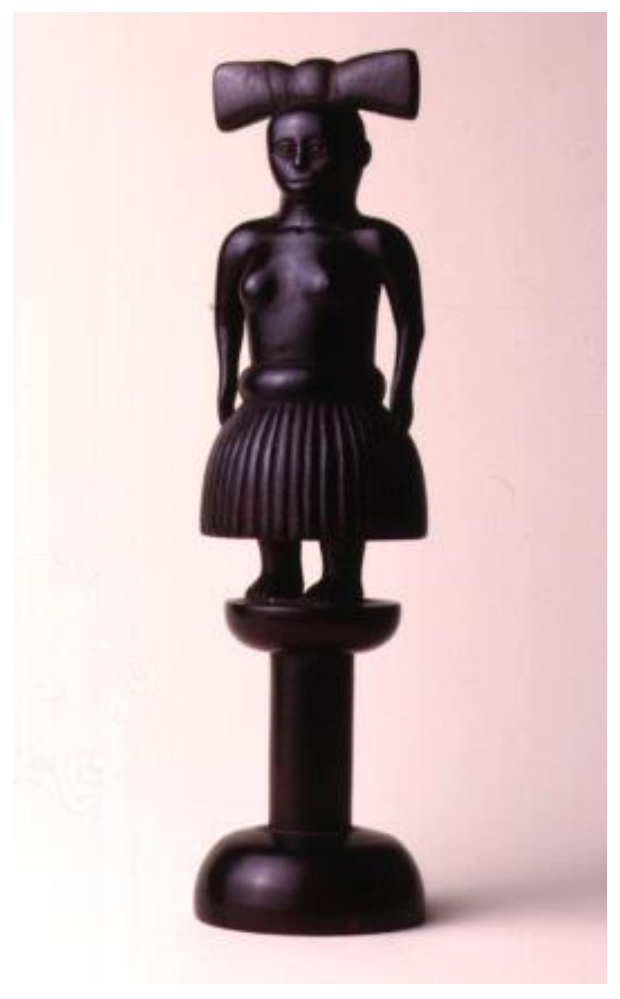

Antônio Gomide realizou seus estudos artísticos em Genebra e Paris, encontrando o grupo modernista paulista em 1924. Em carta para Mário de Andrade, de 14 de maio deste mesmo ano, Brecheret, em Paris, registra sobre Gomide "grande pintor moderníssimo e muito sólido, a arte que ele faz atualmente são Afrescos, que é uma coisa dificílima, que bom mais um no nosso grupo, dos nossos, ele agora está preparando-se para uma exposição em S. Paulo, você verá que bicho" ${ }^{40}$. Descida da cruz aproxima-se visualmente das soluções plásticas das figuras de Brecheret, possivelmente ambos influenciados pelo "art deco" 41, além disso, esta tela recupera soluções do afresco, devido à tinta espessa cuja textura assemelha-se à consistência da argamassa das paredes ${ }^{42}$.

${ }^{39}$ BATISTA, Marta Rossetti. Coleção Mário de Andrade: religião e magia, música e dança, cotidiano. São Paulo: Editora da Universidade de São Paulo: Imprensa Oficial do Estado, 2004, p. 238.

${ }^{40}$ Correspondência ilustrada de Victor Brecheret a Mário de Andrade. Paris, 14 maio 1924, pertencente à Coleção Mário de Andrade, da Coleção de Artes Visuais do IEB USP, código de referência: MA-0131.

41 BATISTA, Marta Rossetti e LIMA, Yone Soares de, p. XXXIX.

42 Gomide realizou muitos afrescos, incluindo o pátio interno da Villa Kyrial, em que retratou "uma Nossa Senhora estilizada com um arrojado manto em tons de vinho, realizado após o regresso do artista ao Brasil, em fins de 1926". In: CAMARGOS, Marcia. Villa Kyrial: crônica da Belle Époque paulistana. 2a ed. São Paulo: Editora SENAC, 2001, pp. 49-50. 

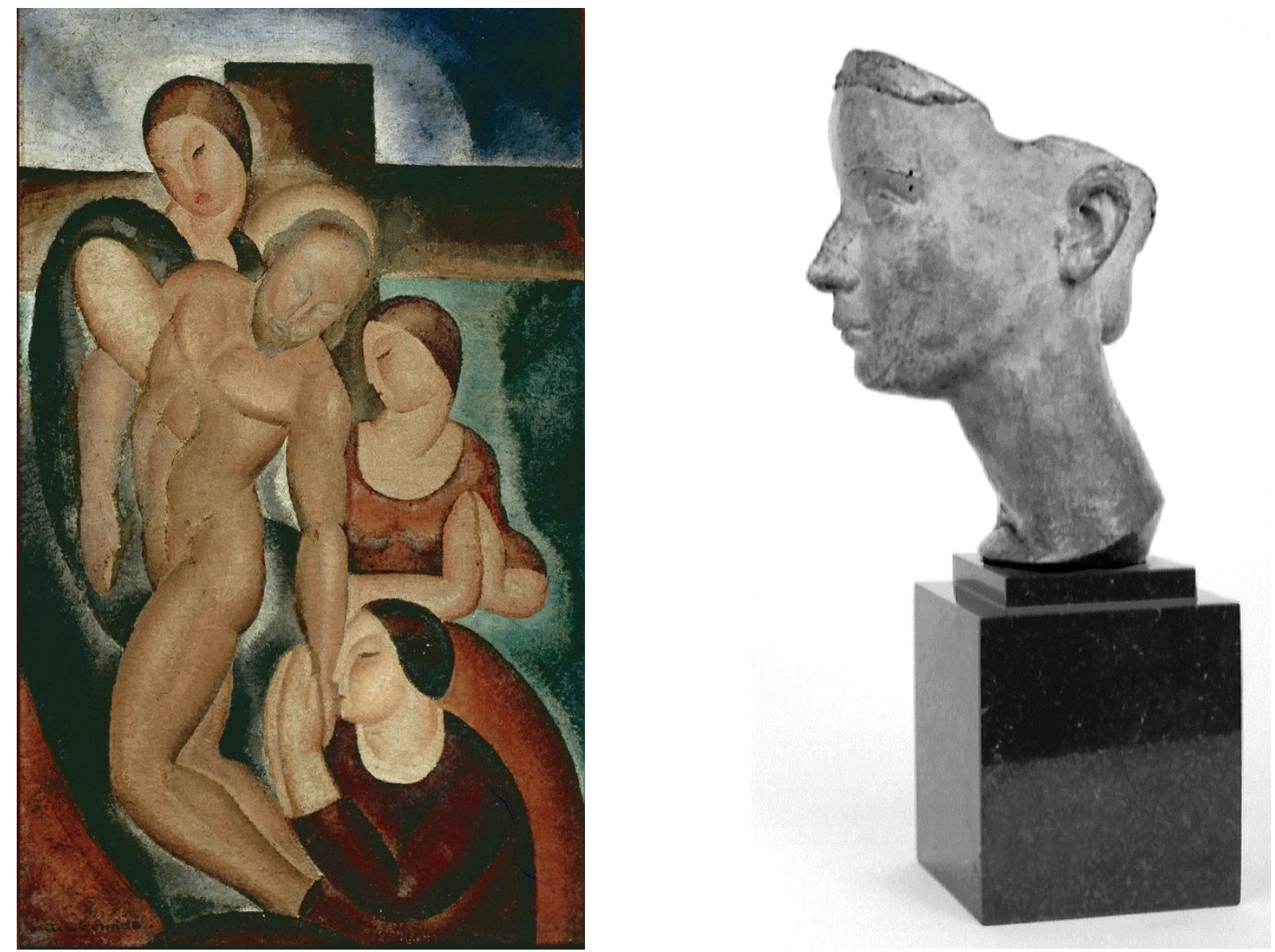

Imagem 62 e 63. Descida da cruz, GOMIDE, Antônio Gonçalves, s.d., óleo sobre tela, 55.3 X $33.0 \mathrm{~cm}$ e Rosto feminino, BRECHERET, Victor, década de 30, séc. XX, terracota, $24.5 \times 14.5 \mathrm{~cm}$.

Fonte: Coleção Mário de Andrade - Coleção de Artes Visuais do Instituto de Estudos Brasileiros da USP.

Mário de Andrade refere-se à aquisição desta obra com Cândido Portinari, em carta de 14 de março de 1936, quando já está no Departamento de Cultura e monta seu escritório. Então como Diretor desta instituição, gostaria que seu gabinete fosse "artisticamente arranjado, que pudesse bem representar a força de São Paulo e seus artistas", assim "cava" com Gomide "o melhor quadro dele ${ }^{43}$, que é realmente muito bom" ${ }^{44}$. Aqui explicita de forma clara seu envolvimento com o meio paulistano e o desejo de se apresentar inserido e originado desta fonte.

Em 1929, durante a queda da bolsa de Nova York, Brecheret encontrava-se em Paris, neste período, dedicou-se a temas relacionados à figura feminina e aos rostos infantis e, devido às dificuldades da situação financeira, trabalhou com a terracota ${ }^{45}$. Esta escultura feminina infantil retoma questões tradicionais do rosto, neste caso sem estilização nem soluções já experimentadas anteriormente, mas sim com traços realistas e ligados à

${ }^{43}$ Existem duas obras, esta tela e uma xilogravura, de autoria de Antônio Gomide na coleção de Mário de Andrade. Acredita-se se tratar aqui da Descida da cruz, uma vez que o autor refere-se a um quadro, além de considerar um contra-senso gravuras e desenhos colocados em moldura.

${ }^{44}$ Portinari, amico mio: cartas de Mário de Andrade a Portinari. FABRIS, Annateresa (org.). Campinas / Rio de Janeiro: Mercado de Letras, Autores Associados / Projeto Portinari, 1995, p. 52.

${ }^{45}$ PICCININI, Daisy. Brecheret: a linguagem das formas. São Paulo: Instituto Victor Brecheret, 2004, p.90. 
escultura grega clássica. Parece que Mário de Andrade já vislumbrava a transformação da obra do escultor neste momento, pois, em suas anotações a lápis na capa do catálogo da exposição de Victor Brecheret em 1930, registrou a renovação dos ritmos plásticos realizados ligados à natureza, quando deveriam realizar-se apesar dela.

Quando Tarsila do Amaral seguia para a França, mencionou em correspondência, a Mário, de 20 de novembro de 1922 que lhe arranjaria um Picasso. Já em 11 de janeiro de 1923, o poeta de Paulicéia Desvairada já agradece e se põe "a imaginar a lindeza do [seu] meu Picasso" 46 . Segundo pesquisa da Prof. a Aracy Amaral o tema do Arlequim "comparece com frequência nos trabalhos de Picasso em 1917-18" "47. Assim, como também na produção de Mário de Andrade, como por exemplo, na capa de Paulicéia Desvairada, ou ainda no poema "Silêncio em tudo" da Lira Paulistana, analisado pela Prof.a Gilda Mello e Souza. A busca das festas e do lazer populares se verifica neste tema e nos de palhaços e circo, habituais neste segmento, numa espécie de culto às origens singulares.

[...] Arreliquim é corruptela de 'arlequim' e designa o personagem da commedia dell'arte, mas na forma aclimada (ou abastardada) em que aparece no bailado popular do Bumba-meu-boi. É portanto uma deformação brasileira, embora conserve as características básicas do modelo europeu de que proveio: esperteza, insolência, certa graça na movimentação. No bailado popular o arreliquim é o ajudante de ordens, o lugar-tenente do Cavalo marinho, e este, tratado também por Capitão, é o personagem principal do folguedo, onde representa o proprietário da fazenda. É por intermédio do arlequim ou arreliquim que o Capitão se dirige aos vaqueiros ${ }^{48}$.

Durante a transferência da coleção de Mário de Andrade para a Universidade, esta obra permaneceria com sua família, não integrando o conjunto que seguira em 1968.

${ }^{46}$ Correspondência Mário de Andrade \& Tarsila do Amaral. AMARAL, Aracy (org.). São Paulo: EDUSP/IEB, 2001, p. 51.

${ }^{47}$ Ibidem, nota 1 "[...] Depois do nascimento do filho Paulo (1921), de sua união com Olga, vê-se o tema do menino-arlequim emergir por volta de 1924: Paulo como Arlequim (1924), no Museu Picasso, em Paris, neste caso mais realista e mais próximo do Arlequim da coleção Mário de Andrade; trata-se de trabalho de extrema leveza, gracioso, um pequeno arlequim de pé, realizado com pinceladas rápidas, gestuais e contidas ao mesmo tempo. Paulo como Pierrot seria igualmente retratado em 1925 por Picasso.

${ }^{48}$ SOUZA, Gilda de Mello e \& CANDIDO, Antonio. A lembrança que guardo de Mário. Revista do Instituto de Estudos Brasileiros, São Paulo, 36: 9-25, 1994, p. 23. 

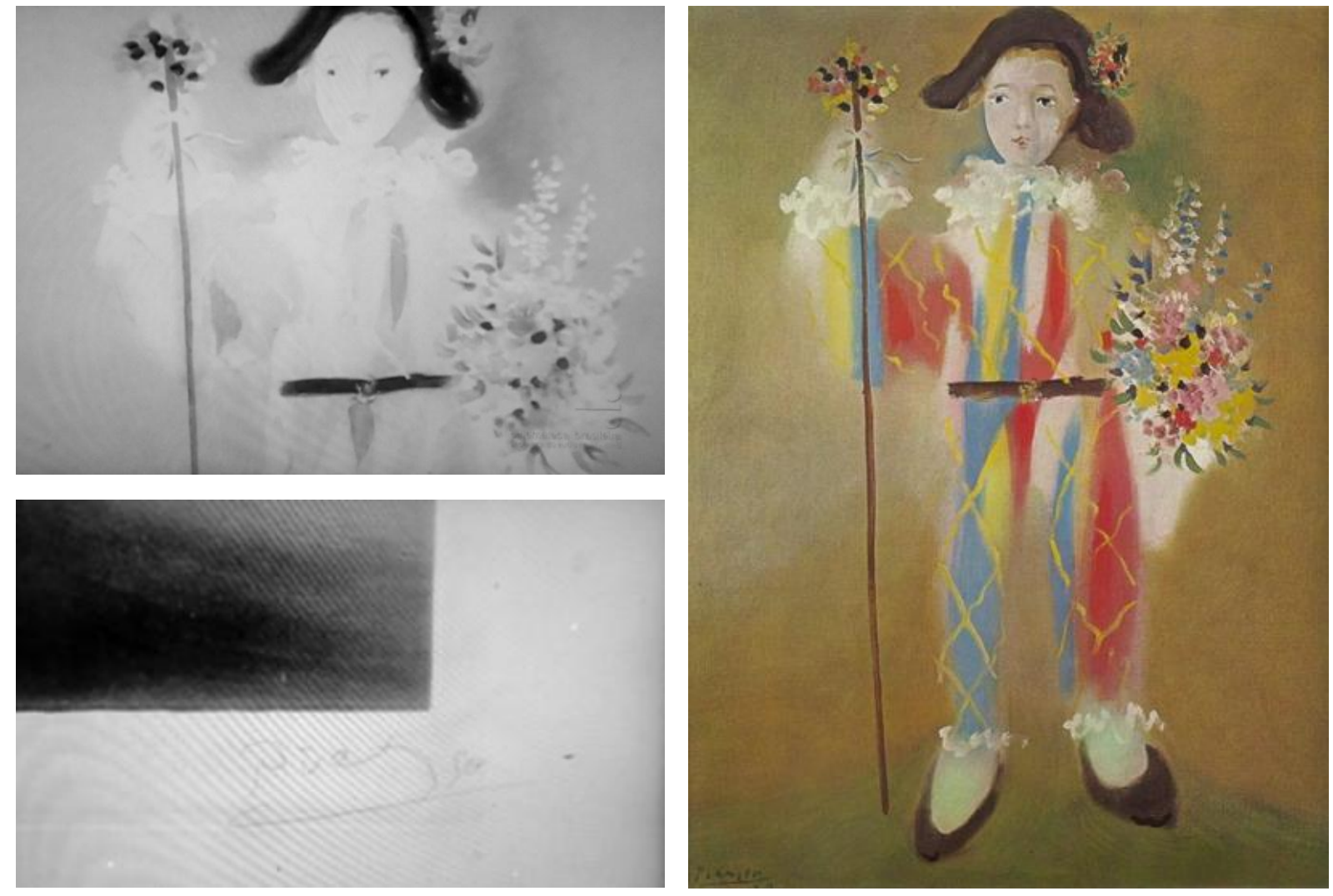

Imagem 64 e 65. Arlequim, gravura atribuída a Pablo Picasso ${ }^{49}$.

Fonte: A Casa de Mário de Andrade. SANTOS, Ruy (direção). São Paulo: Rangel Filmes Ltda, 1955.

Imagem 66. Para comparar o Arlequim de Mário, reproduziu-se Paulo Arlequim de Pablo Picasso, 1923/24, óleo sobre tela, $92.1 \times 73.6 \mathrm{~cm}$. The Nahmad Collection, 2011 ProLitteris, Zurich.

Fonte: Disponível em <http://art-folio.ch/2011/10/26/kunsthaus-zurich-courts-controversy-with-nahmad-show-2/>. Acesso em 05 jul. 2011.

${ }^{49}$ Entrevista Antonio Candido a A., 27 de outubro de 2011. 


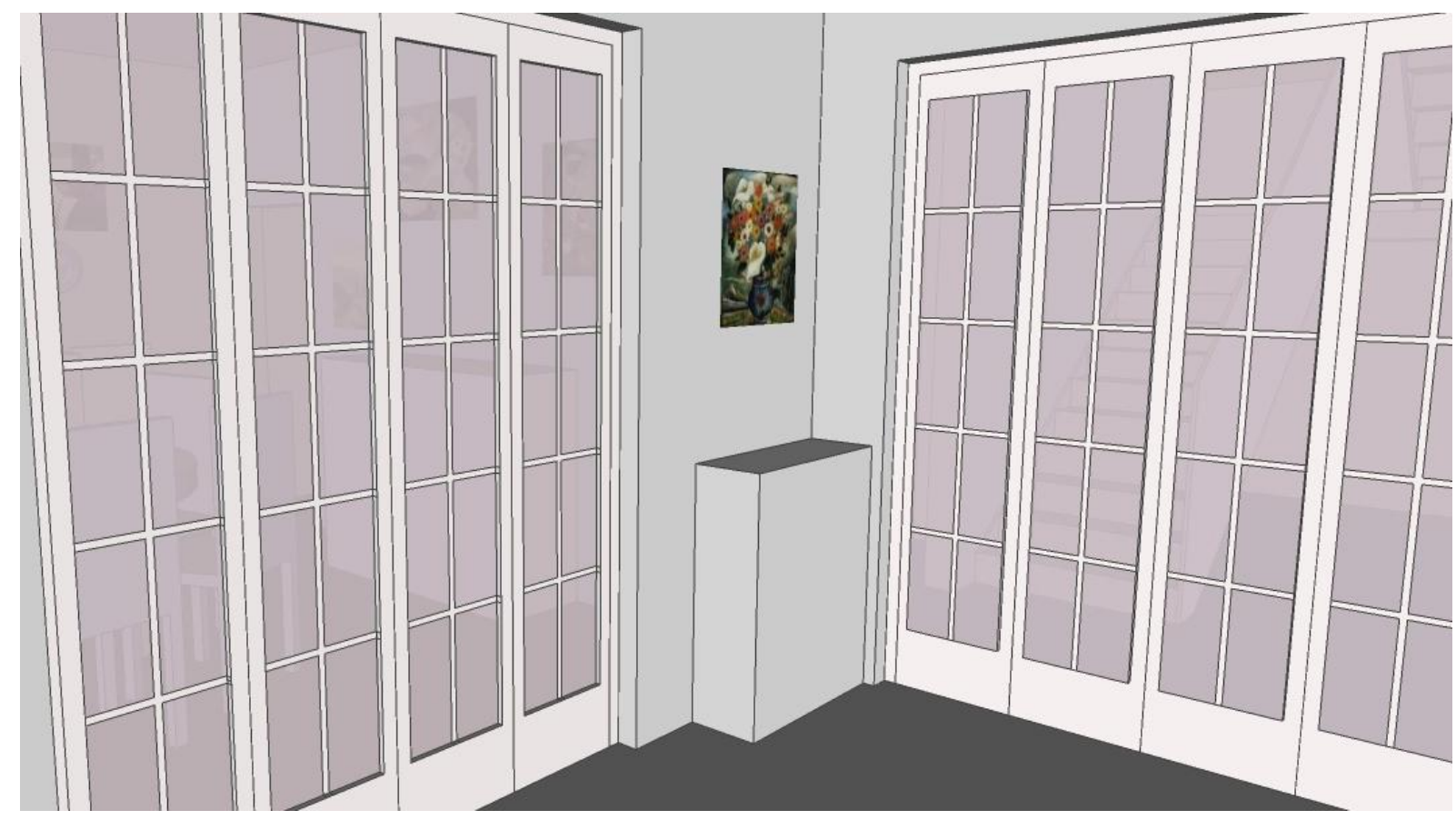

Imagem 67. Vista do hall entre a sala de visitas e de jantar.

Fonte: Maquete eletrônica da casa de Mário de Andrade. Camila Lacerda, 2012.

A única referência a esta área intermediária é a fotografia de Tana, cozinheira da casa, em que se observa atrás dela a pintura Vaso com flores de Alberto da Veiga Guignard, pela qual Mário de Andrade se interessava possivelmente, desde o Salão Nacional de Belas Artes de 1929. Já em 1934, por ocasião do 10 Salão Paulista de Belas Artes, o colecionador chama a atenção das flores, possivelmente assemelhadas às suas, escreveria:

Mais interessante é Veiga Guignard. No meio de tanta materialidade, disfarçada ou não, sem ser um vate, este pintor é um verdadeiro lírico. Não abre caminho, me parece, e mesmo sua obsessão pelas combinações de azul e verde, me desgosta bem, mas é um pintor, um ser interiço de pintura, uma personalidade. Uma fatalidade que tem o direito de pairar além dos interesses da vida. As flores e a sua Brasileira, dum lirismo delicadíssimo, são adoráveis ${ }^{50}$.

${ }^{50}$ ANDRADE, Mário de. O Salão Paulista II. Diário de São Paulo, 4 fev. 1934. 


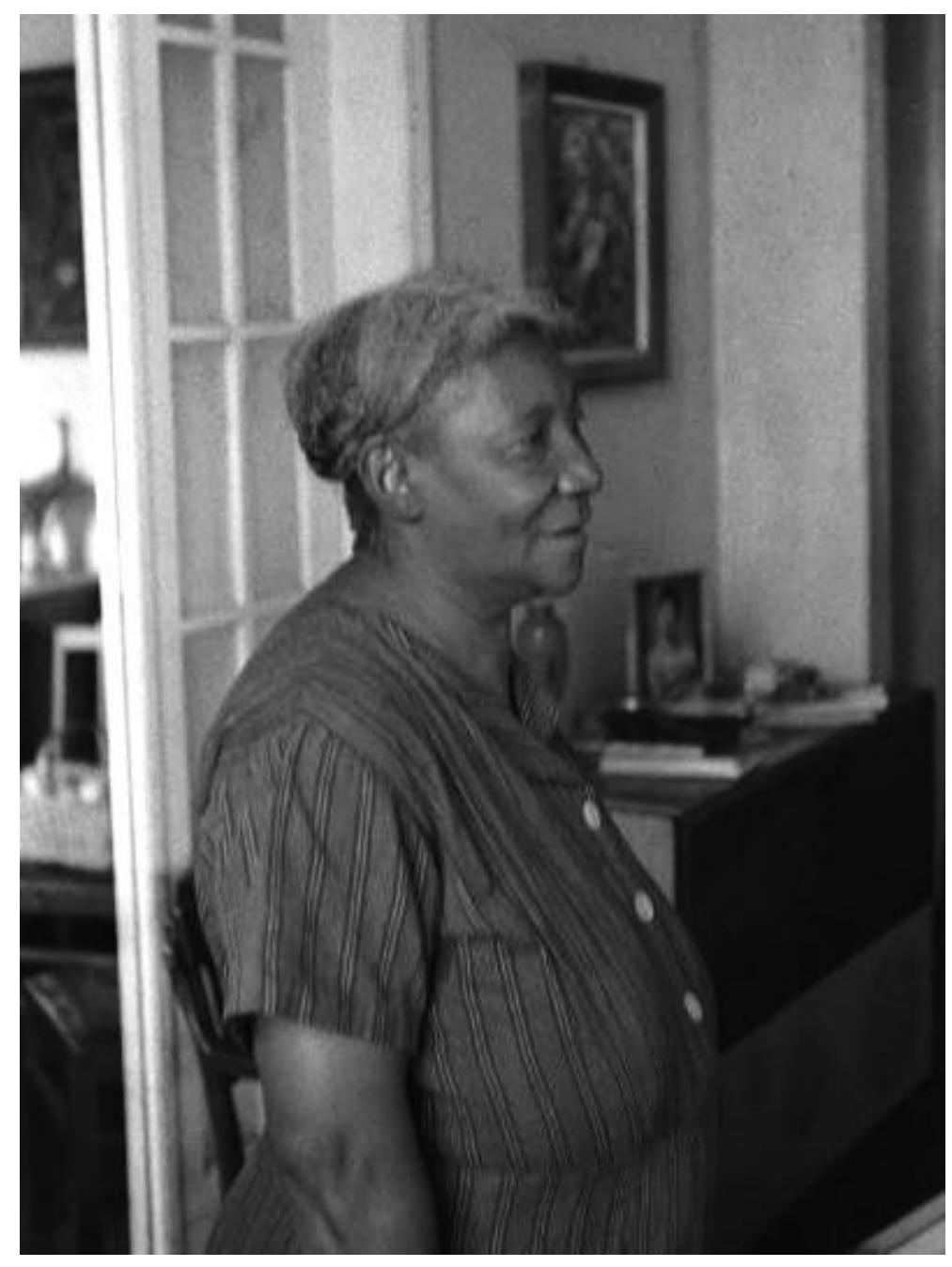

Imagem 68. Sebastiana de Campos e Silva, Tana, cozinheira da Lopes Chaves desde 1925. No plano de fundo a direta, a obra Vaso com flores.

Fonte: MARTINS, Justino. Presença e Ausência de Mário de Andrade. Ed. Keffel (fotografias). Revista do Globo. Porto Alegre, 23 fev. 1946.

Juntamente com as flores de Clóvis Graciano, este Vaso com flores de Guignard são as únicas duas pinturas de flores da coleção e é em texto sobre aquele artista que, Mário de Andrade trata desta "temática livre" como sendo a "arte pura: decorativa e uma funcionalidade de puro prazer estético" ${ }^{51}$. É possível que o interesse do crítico vá em direção, não só à fruição estética, como também à concretização da obra pelo artista, conseguida pela conjunção entre a utilização da técnica, a sua virtuosidade e o conhecimento das soluções previamente utilizadas por outros artistas, vale dizer, pela teoria e prática do artefazer aliadas às experiências precedentes ${ }^{52}$. Imagina-se, que tamanho interesse pela solução técnica do artista, não tenha passado despercebido ao colecionador a figura por detrás das flores.

${ }^{51}$ ANDRADE, Mário de. Ensaio sobre Clóvis Graciano - 1944. In: MOTTA, Flávio. A Família Artística Paulista. Revista do Instituto de Estudos Brasileiros, São Paulo, 10: 137-175, 1971, p. 162.

${ }^{52}$ ANDRADE, Mário de. O artista e o artesão. Aula inaugural dos cursos de Filosofia e História da Arte, do Instituto de Artes, da Universidade do Distrito Federal em 1938. São Paulo: Centro de Estudos Folclóricos do Gfau, 1955. 

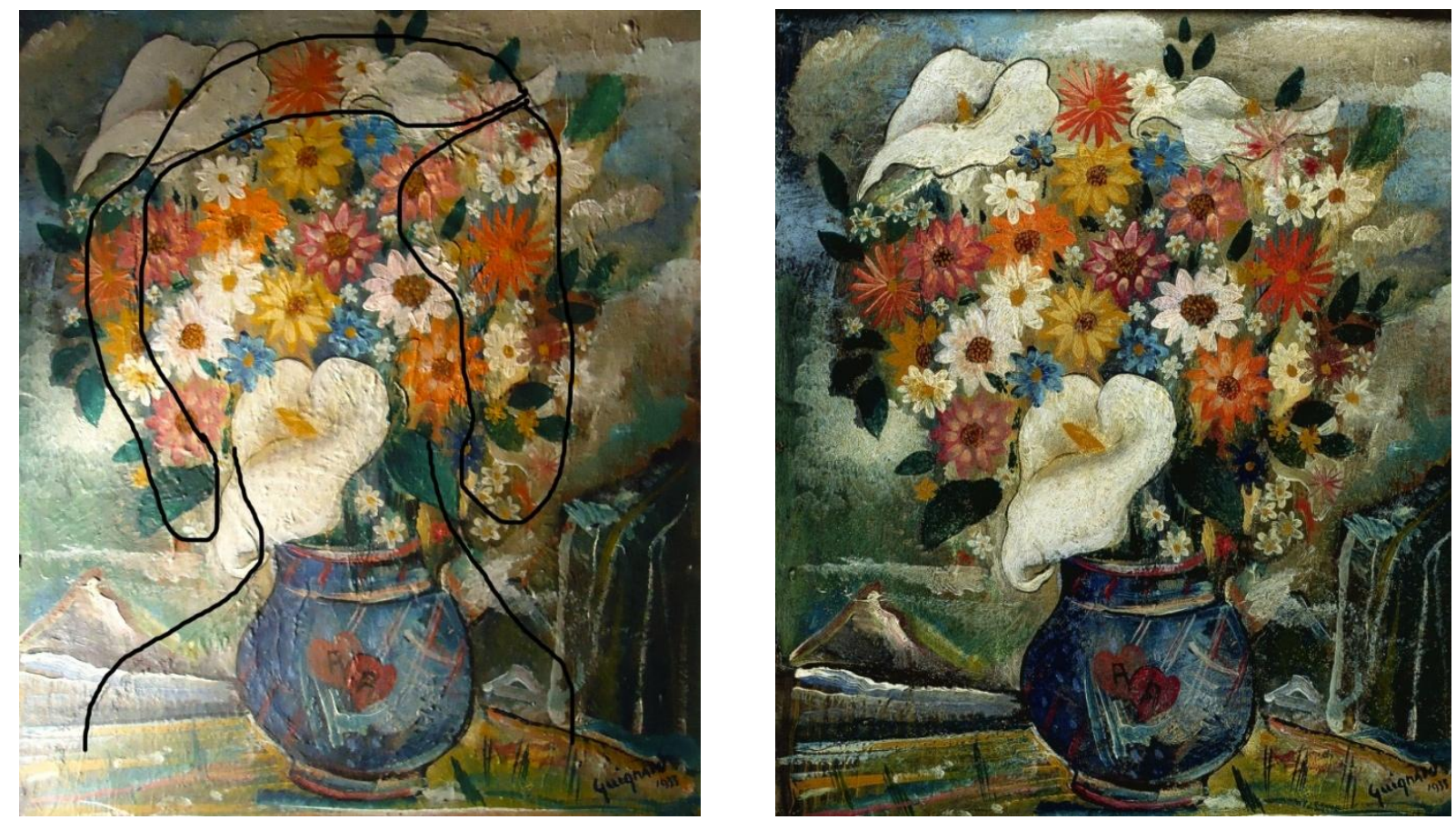

Imagem 69 e 70. Sinais que nos permite observar figura por de trás da pintura e Vaso com flores de GUIGNARD, Alberto da Veiga, 1933, óleo sobre cartão rígido, $41.5 \times 34.0 \mathrm{~cm}$.

Fonte: Coleção Mário de Andrade - Coleção de Artes Visuais do Instituto de Estudos Brasileiros da USP.

\section{Sala de Jantar}

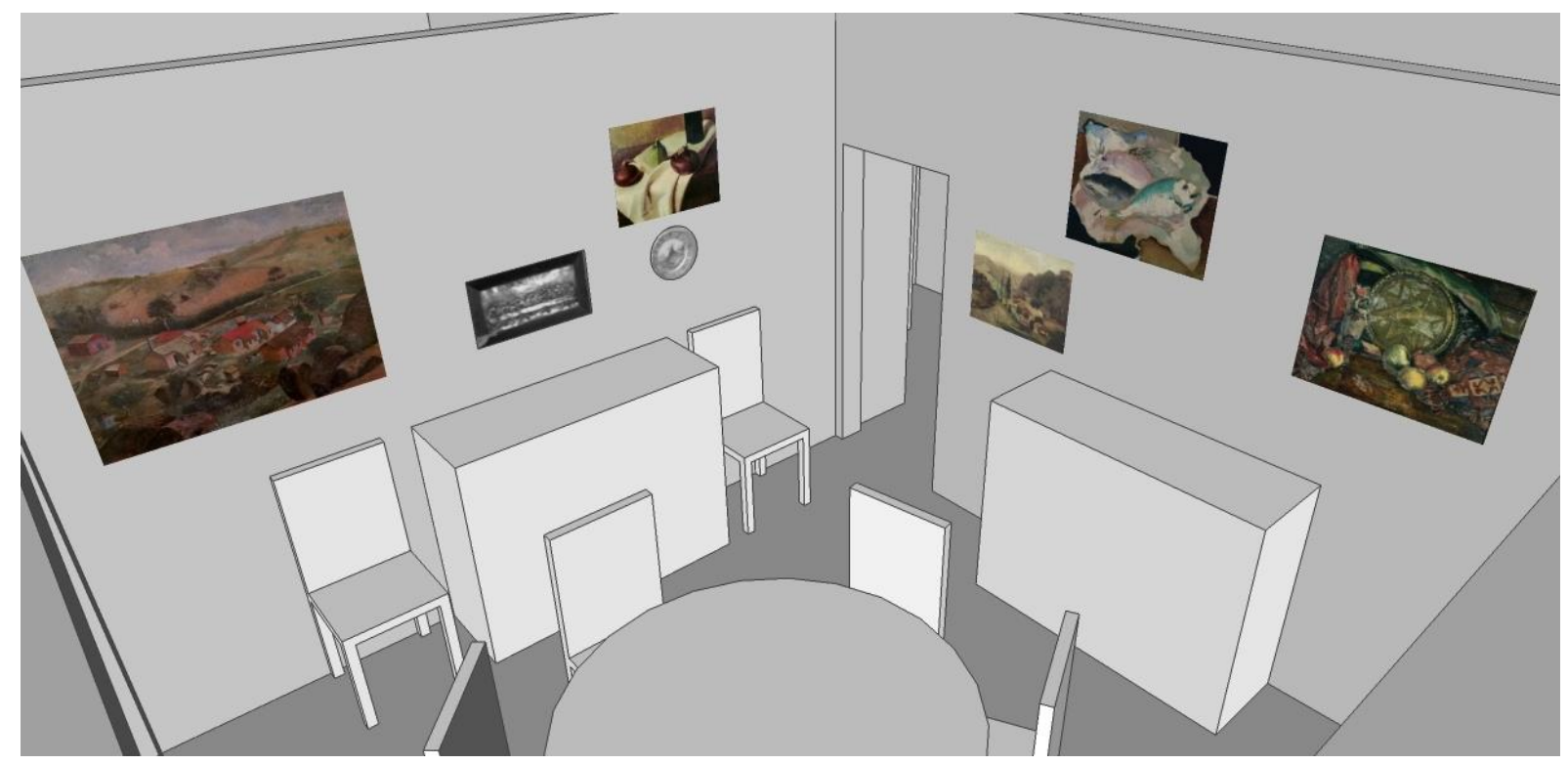

Imagem 71. Vista da sala de jantar.

Fonte: Maquete eletrônica da casa de Mário de Andrade. Camila Lacerda, 2012. 
A sala de jantar possui uma mesa redonda com seis cadeiras, mais duas ao lado da étagère, móvel destinado para guardar louças além de servir como aparador, e por fim um guarda louça. Este cômodo possui porta para a copa, assim a circulação de pratos durante as refeições é feita diretamente, sem interferir nas áreas públicas da casa. As decorações das paredes deste cômodo são "quadros, painéis e faianças finas, [...] 'bonitas paisagens, fatos históricos, fábulas, etc'" ${ }^{53}$. Na casa de Mário de Andrade, além de pratos decorativos e de uma Santa Ceia, os quadros ou possuem temática de paisagens ou de naturezas-mortas. No depoimento da Prof.a Gilda, com o crescimento da coleção, "a grande paisagem de Rebolo e as diversas naturezas mortas, de Anita, de Gobbis $^{54}$, de Enrico Bianco, expulsaram a modesta ceiazinha do Senhor em baixo relevo".
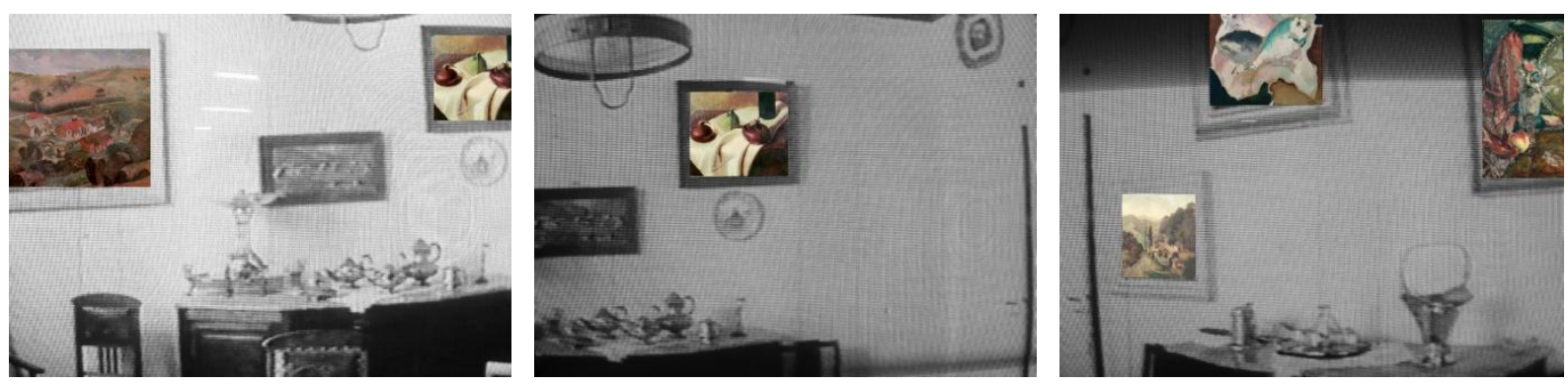

Imagem 72, 73 e 74. Disposição das obras e do mobiliário da sala de jantar.

Fonte: Casa de Mário de Andrade. SARNO, Geraldo (dir.); FARKAS, Thomaz (fot.). São Paulo: IEB USP, 1968.

A formação de grupos artísticos tais como o Santa Helena e o Seibi ampliou o segmento não-acadêmico, cujo interesse era dedicar-se inteiramente à pintura ${ }^{55}$. Estes grupos proletários e pequenos burgueses não possuíam "consciência de classe claramente firmada", nem tampouco "estavam em circunstâncias financeiras tão precárias que sentissem fisicamente fome. Mas se não tinham a exigência física da forma, tinham a presença psíquica do se fantasma, acentuada pela 'tradição' que aspirava a subir" ${ }^{56}$. Assim as naturezas-mortas, principalmente os "comestíveis", tornaram-se uma das temáticas preferidas dos artistas da Família Artística Paulista.

As paisagens também seguem a mesma linha das necessidades dos "operários da modernidade", pois como trabalhadores folgavam durante os fins de semana, quando, em seu horário de lazer, iam à busca do que lhes dessem um sentimento agradável como:

[...] praias, esportes marinhos, casinhas operárias arrabaldeiras, chacrinhas operárias suburbanas [...]. Nada de perceber as paisagens deslumbrantes, onde é mais fácil encontrar o dedo de Deus, Alto da Serra, os luxos amplos dos

${ }^{53}$ CARVALHO, Vânia Carneiro de, op. cit., p. 118.

${ }^{54}$ Acredita-se que seja um lapso, trocando Adami por Gobbis, uma vez que não temos conhecimento de nenhuma natureza-morta deste na coleção de Mário de Andrade.

55 LOURENÇO, Maria Cecília França. Operários da modernidade. São Paulo: HUCITEC / EDUSP, 1995, p. 18.

${ }^{56}$ ANDRADE, Mário de. Ensaio sobre Clóvis Graciano - 1944, op. cit., p. 162. 
perfis da Cantareira, ou Campos do Jordão. [...] jamais o Guarujá mirífico, mas com frequência Itanhém ${ }^{57}$.

Estes grupos concretizaram a pesquisa estética apregoada pelo autor de $O$ movimento modernista, ao privilegiar as questões técnicas e estéticas do bem fazer artístico, cujas soluções "temáticas populares produzindo uma mistura bem ao gosto do nosso sincretismo cultural, ou de uma voracidade antropofágica", convergindo para "simplificações representativas, numa discreta deformação, no gosto pela harmonia construtiva, bem como num afastamento à simples documentação fotográfica" 58 .

As paisagens de Rebolo possivelmente foram realizadas nos arredores de São Paulo, em ambas a perspectiva, de cima para baixo, permitiu grande profundidade, de forma a definir sucessão de casas, vegetação e colinas distantes ao fundo.
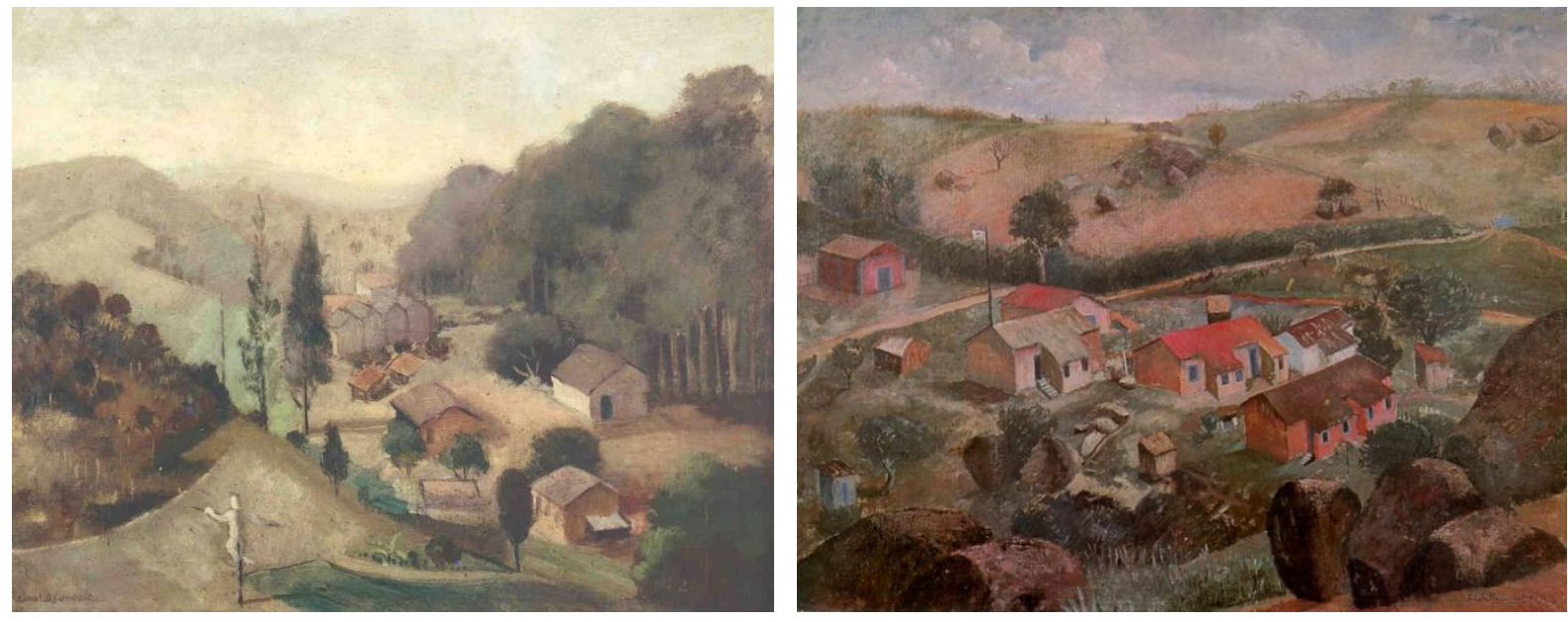

Imagem 75 e 76. De REBOLO Gonsales, Francisco, Paisagem com espantalho óleo sobre tela, s.d., 40.0 X 50.3 $\mathrm{cm}$ e Paisagem com casas, 1940, óleo sobre tela, 73.5 X $92.5 \mathrm{~cm}$.

Fonte: Coleção Mário de Andrade - Coleção de Artes Visuais do Instituto de Estudos Brasileiros da USP.

É importante ressaltar que nenhum dos três artistas, Malfatti, Adami e Bianco, fazia parte da Família Artística Paulista, contudo é inegável a aproximação de suas naturezasmortas àquele grupo. Para além dos alimentos comestíveis, as telas são compostas por planos de apoio, panejamento, e outros objetos, respectivamente garrafa, janela e cesta, tudo para dar à composição a proporção do segmento áureo ${ }^{59}$. Dessa forma, os artistas poderiam exercer sua técnica como "fenômeno de relação entre o artista e a matéria que ele move" ${ }^{60}$. Anita Malfatti presidiu o Sindicato dos Artistas, local freqüentado pelos componentes do Grupo Santa Helena, além de ser já uma personalidade reconhecida na meio como precursora, logo com livre trânsito entre os grupos.

\footnotetext{
57 Ibidem, p. 159.

58 LOURENÇO, Maria Cecília França, op. cit., p. 19 e 67.

${ }^{59}$ A proporção áurea, número de ouro, número áureo ou proporção de ouro é uma constante algébrica, cujo valor é 1.618 e está associada à ordem de crescimento de várias espécies na natureza, como por exemplo a concha de nautilus, e, também, nas composições artísticas.

${ }^{60}$ ANDRADE, Mário de. $\mathrm{O}$ artista e o artesão, op. cit.
} 
Anita Malfatti está no cenário artístico desde o início do modernismo, após a Semana de Arte Moderna, a artista segue para Paris, a partir de então envereda para as questões do bem-fazer artístico, tal como a Família Artística Paulista. Já Adami, atuante desde a década de 1920, emergiu na cena artística apenas na seguinte quando retornou de viagem de estudos na Itália, local em que possivelmente realizou estas Cebolas adquiridas por Mário de Andrade. A relação com Enrico Bianco, como antes se analisou, possivelmente se deva a Portinari, de quem era colaborador no Rio de Janeiro e possuidor de bom desenho atraiu a atenção do colecionador.
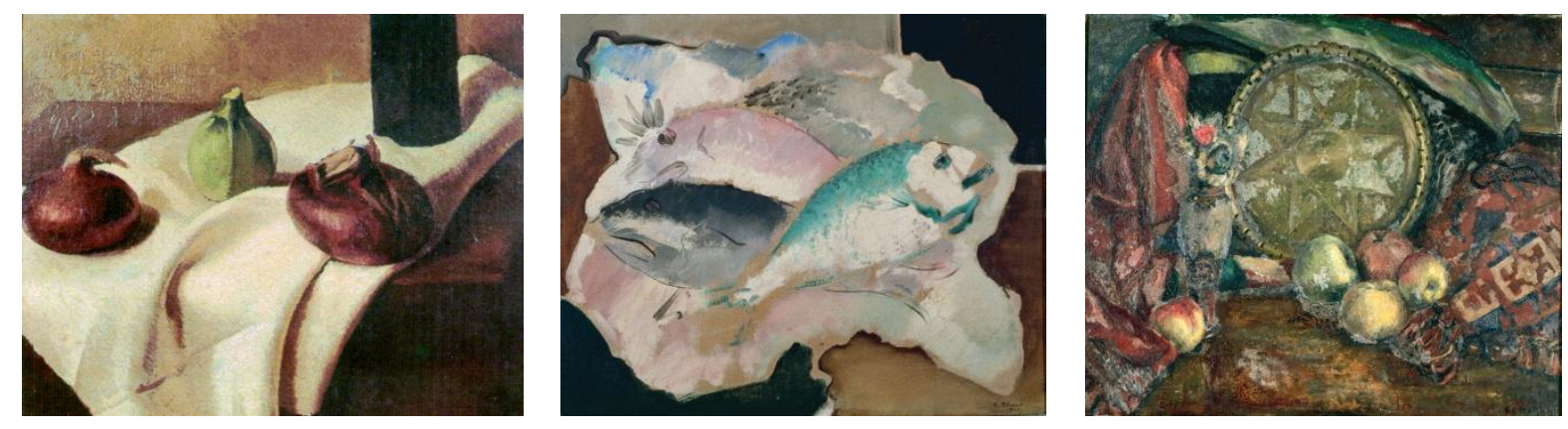

Imagem 77, 78 e 79. Cebolas de ADAMI, Hugo, 1926 c., óleo sobre tela, 43.5 X $54.3 \mathrm{~cm}$, Peixes de BIANCO, Enrico, 1940, óleo sobre tela, 46.0 X $55.5 \mathrm{~cm}$ e Natureza-morta de MALFATTI, ANITA Catarina, 1925 c., óleo sobre tela, $54.6 \times 65.4 \mathrm{~cm}$.

Fonte: Coleção Mário de Andrade - Coleção de Artes Visuais do Instituto de Estudos Brasileiros da USP.

\section{Intervalo entre espaços}

A escada que liga o térreo e o primeiro andar possui bastante visibilidade, tanto para quem está em na cota superior quanto no térreo, o que revela um grande destaque para a escultura Retrato de Mário de Andrade, de Joaquim Lopes Figueira e, principalmente, para a obra Futebol de André Lhote, que possivelmente, aí encontrou sua exposição ao olhar desde sua entrada na coleção em meados de 1924, quando fora adquirida diretamente em Paris, por Tarsila do Amaral ${ }^{61}$.

Joaquim Figueira, membro da Família Artística Paulista, privilegiou aspectos da modelagem, deixando no molde, textura que seria revelada na fundição do bronze, o que denota a presença constante, nas escolhas do colecionador, de suas peças estarem ligadas à manufatura, ao lado artesanal da produção artística. Além disso, a colocação deste busto na escada pode estar associada à presença de Mário de Andrade na casa, conforme se fazia para a "constituição da identidade masculina, referências da sua presença na casa", para reforçar seja o "caráter nobiliante", seja o "lastro" criado pelos objetos e obras ${ }^{62}$.

\footnotetext{
${ }^{61}$ A partir das lembranças da Prof.a Gilda, sabe-se que "em 1930 já ocupava o alto da escada". In: SOUZA, Gilda de Mello e \& CANDIDO, Antonio. A lembrança que guardo de Mário. Revista do Instituto de Estudos Brasileiros, São Paulo, 36: 9-25, 1994, p. 19.

${ }^{62}$ CARVALHO, Vânia Carneiro de, op. cit., pp. 55-56.
} 

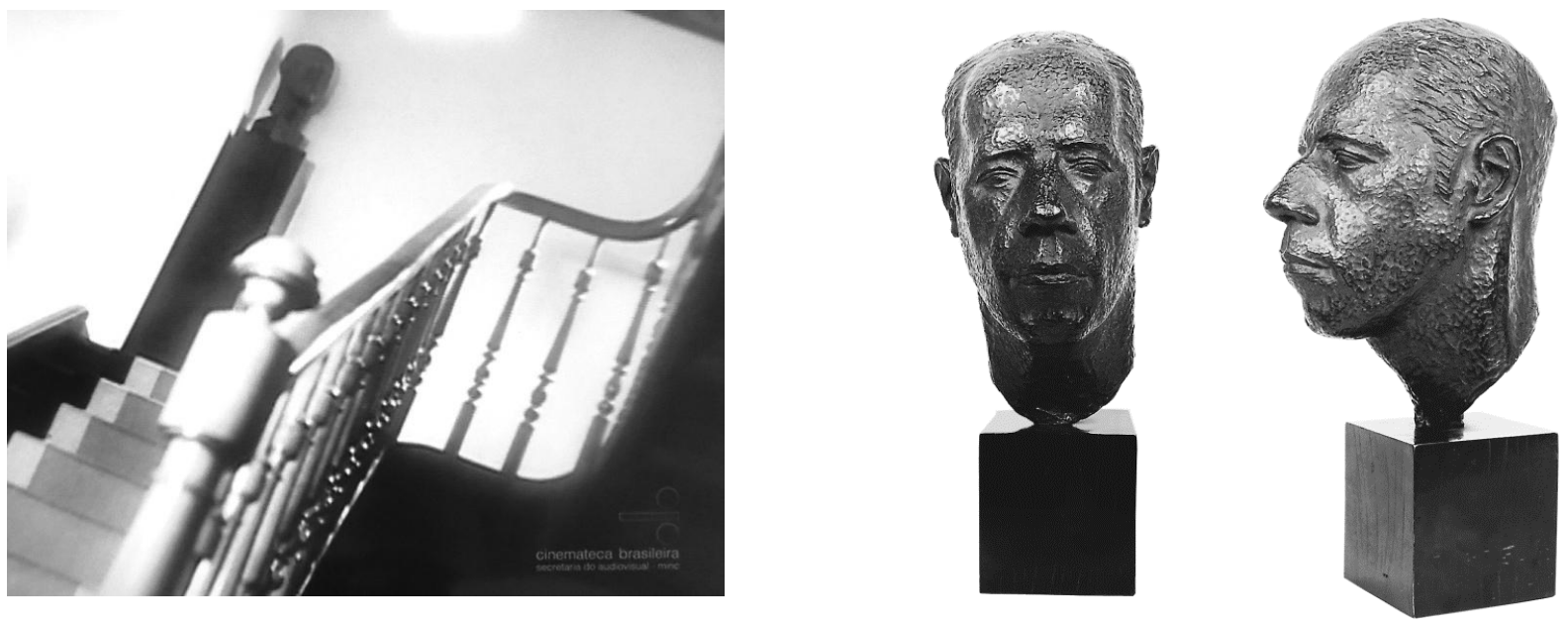

Imagem 80. Vista de quem sobe as escadas.

Fonte: A Casa de Mário de Andrade. SANTOS, Ruy (direção). São Paulo: Rangel Filmes Ltda, 1955.

Imagem 81. Retrato de Mário de Andrade de FIGUEIRA Júnior, Joaquim Lopes, 1938 c., bronze, 34.5 X 20.0 X $26.5 \mathrm{~cm}$.

Fonte: Coleção Mário de Andrade - Coleção de Artes Visuais do Instituto de Estudos Brasileiros da USP.

A associação entre sua imagem e uma obra do cubista André Lhote, professor de Tarsila do Amaral, no centro de convergência da casa, funciona como a criar elo que liga o colecionador e as diversas vertentes da arte moderna, ao mesmo tempo em que arroja ao trazer um nome menos conhecido, Figueira, pintor, desenhista e escultor e que falece em 1943.

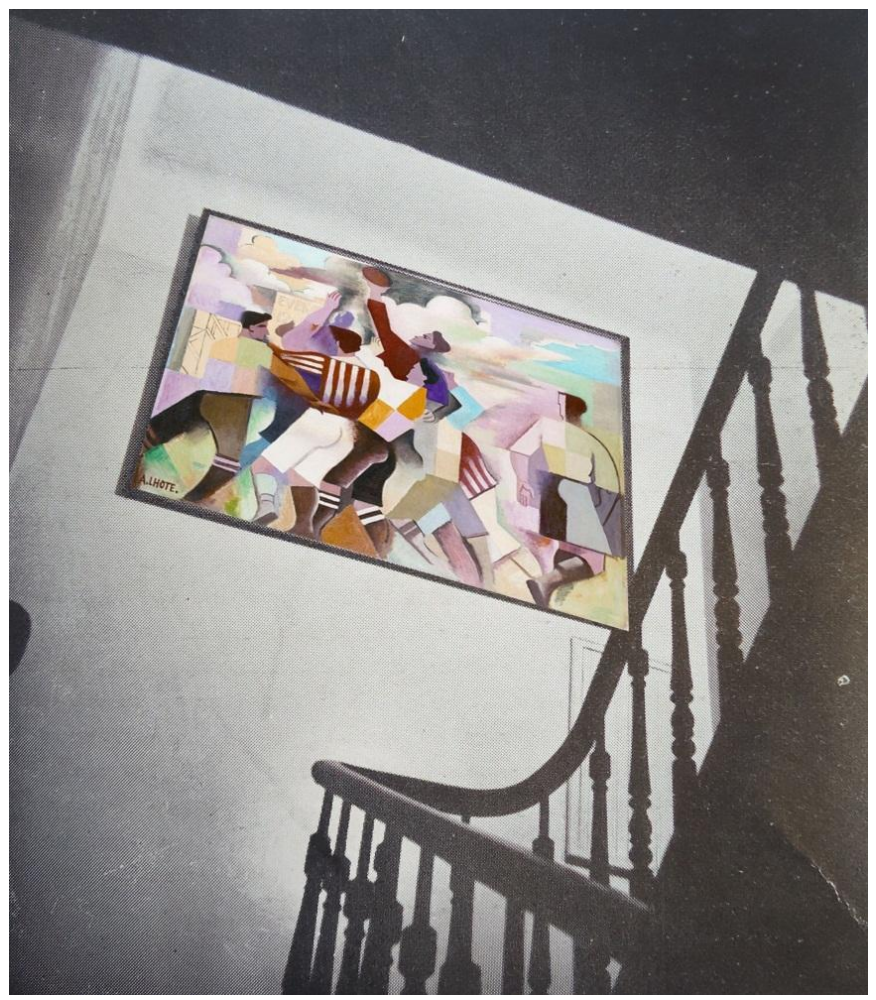

Imagem 82. O Futebol de Lhote na parede da escada da casa de Mário de Andrade.

Fonte: REVISTA do Arquivo Municipal, São Paulo: Departamento de Cultura, ano XII, volume CVI, jan. fev. 1946. 
A questão de Lhote merece considerações, pois Tarsila fora aluna dele e de Fernad Léger, possivelmente parta dessa relação a escolha dessa incorporação a coleção de Mário de Andrade, estando a aquisição de uma pintura daquele mais acessível do que deste. A chegada da tela ao Brasil foi via Ronald de Carvalho, então funcionário da Secretaria de Estados das Relações Exteriores que partira do México para Paris, e de lá para o Rio de Janeiro. O colecionador pede ao seu portador que espere sua ida a então capital brasileira, pois não quer "expor as obras às vicissitudes do nosso Correio", conforme nos revela sua carta a Tarsila de 27 de setembro de $1924^{63}$. Juntamente com o Futebol, viriam obras da própria Tarsila, como a Torre Eiffel de Delaunay. Já em 1926, em carta de 21 de abril, Mário pede a Tarsila que não se esqueça de trazer o desenho preparatório do Futebol. Uma vez que o próprio Lhote pensava que os dois, tela e esboço, deveriam ficar juntos. Contudo, não se tem notícia deste desenho na coleção do escritor.
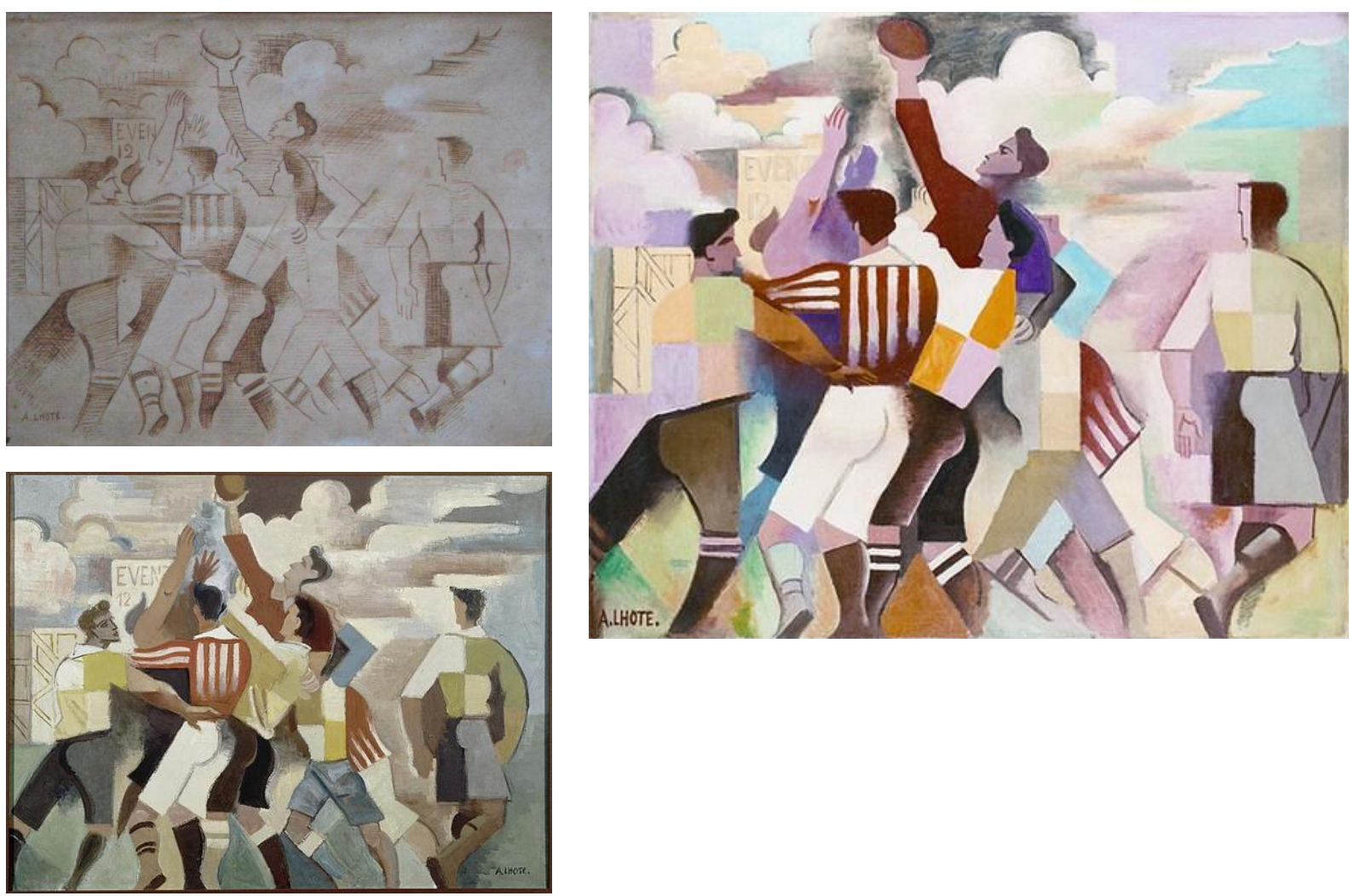

Imagem 83, 84 e 85. LHOTE, André, Futebol, óleo sobre tela, pertencera a Mário de Andrade; Futebol, óleo sobre tela. Outra versão da mesma tela do colecionador ${ }^{64}$; e, LHOTE, André, Futebol, desenho.

Fonte: Disponível em < http://www1.folha.uol.com.br/ilustrada/910180-quadro-que-pertenceu-a-mario-deandrade-vai-a-leilao-em-nova-york.shtml>. Acesso em 10 set. 2011.

Fonte: Pertencente ao Musée Antoine Lécuyer. Disponível em < http://www.histoire-image.org/site /zoom/ pleinecran.php?i=769\&oe_zoom=1377>. Acesso em 22 fev. 2012.

Fonte: Disponível em <http:\|www.papillongallery.comlhote_rugby.html>. Acesso em 06 nov. 2011.

${ }^{63}$ Correspondência Mário de Andrade \& Tarsila do Amaral. AMARAL, Aracy (org.). São Paulo: EDUSP/IEB, 2001, p. 85.

${ }^{64}$ Em depoimento de Antonio Candido, a A. em 27 out. 2011, o Professor mencionou que vira duas versões do Futebol, uma na casa de Mário, outra no MoMA-Nova York, quem sabe não seria esta? 
Seja o rugby, cuja bola é ovalada, seja o futebol, tal como corrente no Brasil com bola redonda, o tema deste esporte é ligado às questões do corpo e da higiene, desenvolvidas consideravelmente durante o início do século XX, e difundia a idéia de corpo e mente sãos, além de contribuir para ressoar o nacionalismo nas torcidas, durante as Olimpíadas e Copas do Mundo ${ }^{65}$. Assim, esta temática chegou às telas, como esta na escada de Mário de Andrade, por meio da geometrização e da justaposição de planos de cor. O próprio autor de Macunaíma, quando foi diretor do Departamento de Cultura, considerva-se a necessidade do esporte para os cidadãos, como competência deste órgão, pois é de sua gestão a iniciativa de construir um estádio municipal, que viria a ser o Pacaembu ${ }^{66}$.

Na década de 1980, o quadro seguiu de volta para a França, após leilão pela Sotheby's, alcançando o lance de $\mathrm{R} \$ 260$ mil. A última notícia desta tela na grande mídia foi em 03 de maio de 2011, quando a mesma casa de leilões, em Nova York, a colocou, com o nome de Les joueurs de rugby, num lote, cujo lance mínimo seria de $\mathrm{R} \$ 785 \mathrm{mil}^{67}$, chegou a alcançar aproximadamente $\mathrm{R} \$ 4.048 .395,00^{68}$.

Em geral, o andar superior da residência é o lugar da privacidade por excelência, no caso da Lopes Chaves, pode-se observar que a região dos quartos dos demais moradores guarda este caráter. Já nos domínios de Mário de Andrade, há uma mescla entre público e privado, uma vez que seu estúdio, no primeiro piso, equivalia ao "lugar de absoluta privacidade masculina, a sua localização acentuava a ligação do homem com o espaço externo" ${ }^{69}$, usualmente ligado diretamente à rua.

65 De 8 set. a 25 nov. 2007, durante a Copa do Mundo de Rugby, no Musée Fabre de Montpellier, ocorreu a exposição "Rugbysme, le rugby et l'art moderne". Disponível em <http://museefabre.montpellieragglo.com/index.php/visiter/les_expositions/rugbysme_le_rugby_et_I_art_moderne>. Acesso em 06 nov 2011.

${ }^{66}$ Em 1936, fora lançada a pedra fundamental do Estádio Municipal do Pacaembu, em terreno doado pela Cia City. In: RAFFAINI, Patrícia Tavares. Esculpindo a cultura na forma Brasil: o Departamento de Cultura de São Paulo (1935-1938). São Paulo: Humanitas / FFLCH USP, 2001, p. 57.

${ }^{67}$ MARTí. Silas. Quadro que pertenceu a Mário de Andrade vai a leilão em Nova York. Folah de São Paulo. São Paulo, 06 maio 2011. Disponível em < http://www1.folha.uol.com.br/ilustrada/910180-quadro-quepertenceu-a-mario-de-andrade-vai-a-leilao-em-nova-york.shtml>. Acesso em 10 set. 2011.

68 HUMBERT, Frederic. Art \& Rugby at Sotheby's. Disponível em <http://rugby-pioneers.blogs.com/rugby/ 2011/07/art-rugby-at-sothebys.html>. Acesso em 22 fev. 2011.

69 CARVALHO, Vânia Carneiro de. Gênero e Artefato: o sistema doméstico na perspectiva da cultura material São Paulo, 1870-1920. São Paulo: Edusp / FAPESP, 2008, p. 138. 


\section{Primeiro andar}

Após subir as escadas, havia um hall de distribuição para os dormitórios, que, em direção para os fundos da casa, se concentravam os quartos de Dona Mariquinha, Gilda de Moraes Rocha e, provavelmente, de Dona Nhanhã. Assim, para o lado da frente da casa, ficavam os domínios de Mário de Andrade. Neste hall de distribuição, se encontrava um importante mobiliário para o pesquisador: o fichário analítico.

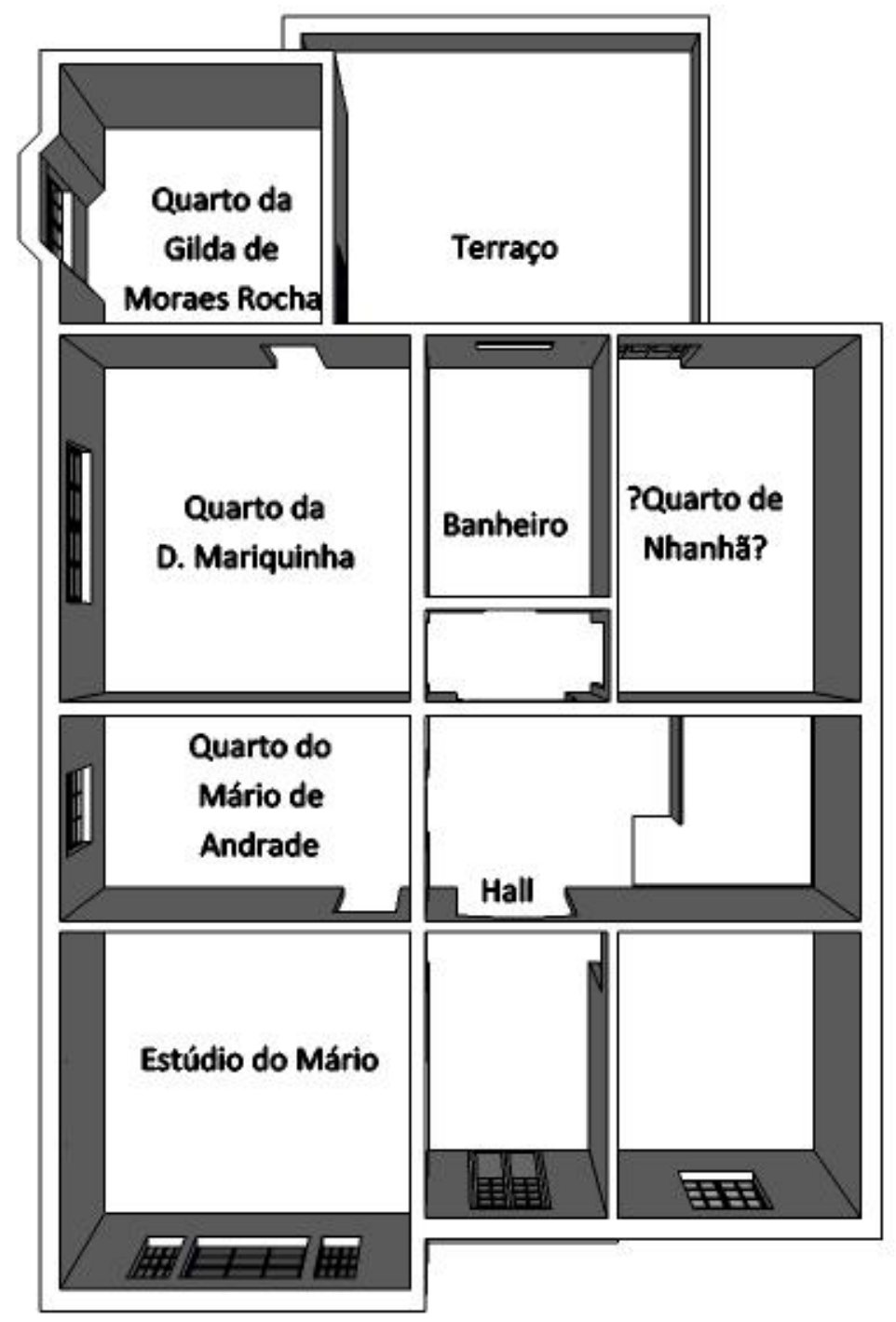

Planta 4. Primeiro andar da Rua Lopes Chaves.

Fonte: Levantamento arquitetônico in loco, documentação da Oficina da Palavra Casa Mário de Andrade e maquete eletrônica realizada por Júlia Ferrari e Camila Lacerda, 2012. 


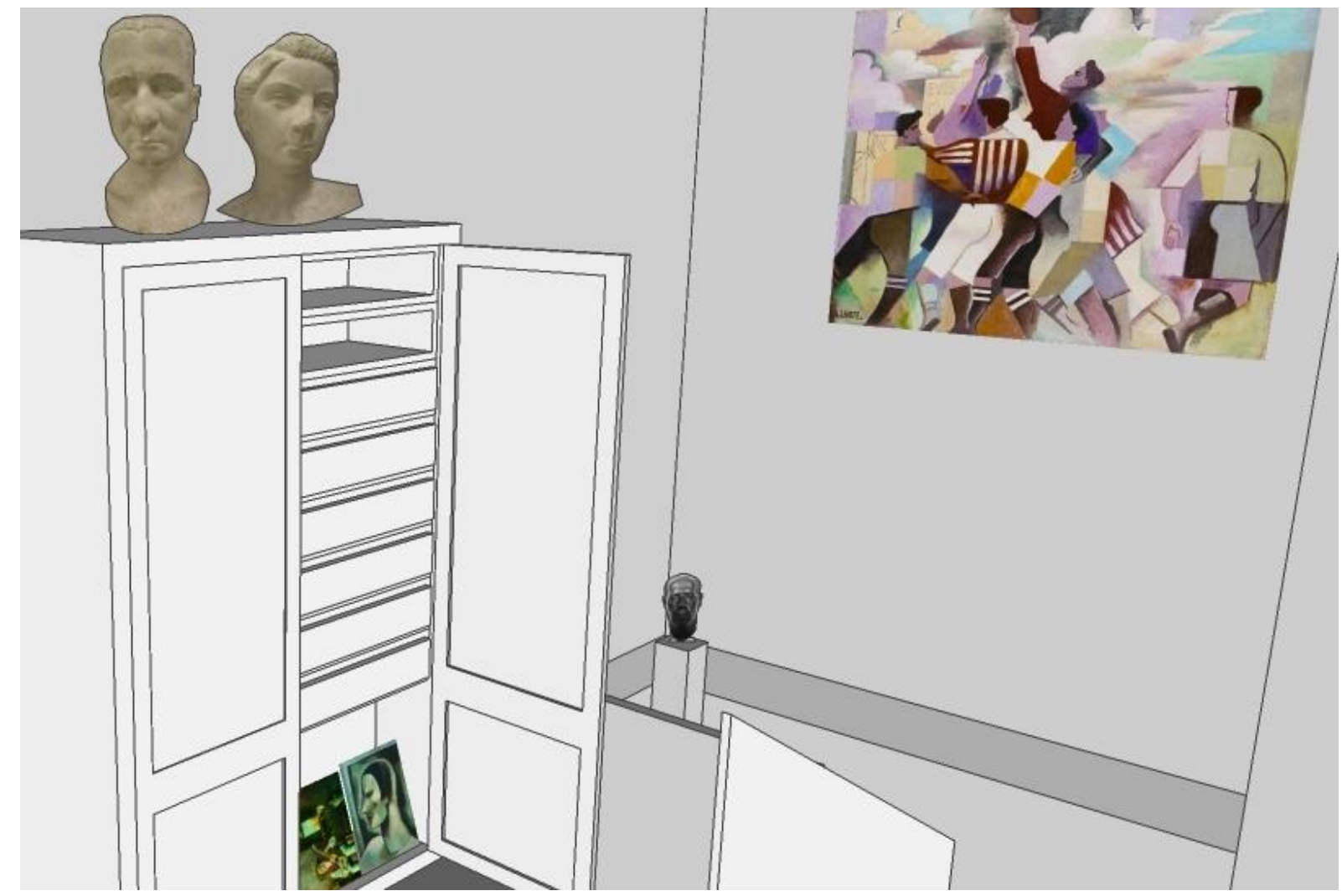

Imagem 86. Vista do hall da escada.

Fonte: Maquete eletrônica da casa de Mário de Andrade. Camila Lacerda, 2012.

Este móvel era feito de estreitas gavetas, próprias paras guardar fichas com anotações e citações, reunidas assunto a assunto em pequenos envelopes. As prateleiras superiores eram livres e poderiam receber as pastas de couro com a coleção de papéis flexíveis, já na parte superior havia algumas obras de arte acondicionadas. Lado a lado a obra Violeiro de Am. Bento e Auto-retrato, que possui no verso Casas, de Ismael Nery, acondicionados em pé de igualdade no fichário.

Imagem 87. Zé Bento manuseia o fichário analítico constituído de fichas guardadas em envelopes.

Fonte: MARTINS, Justino. Presença e Ausência de Mário de Andrade. Ed. Keffel (fotografias). Revista do Globo. Porto Alegre, 23 fev. 1946.

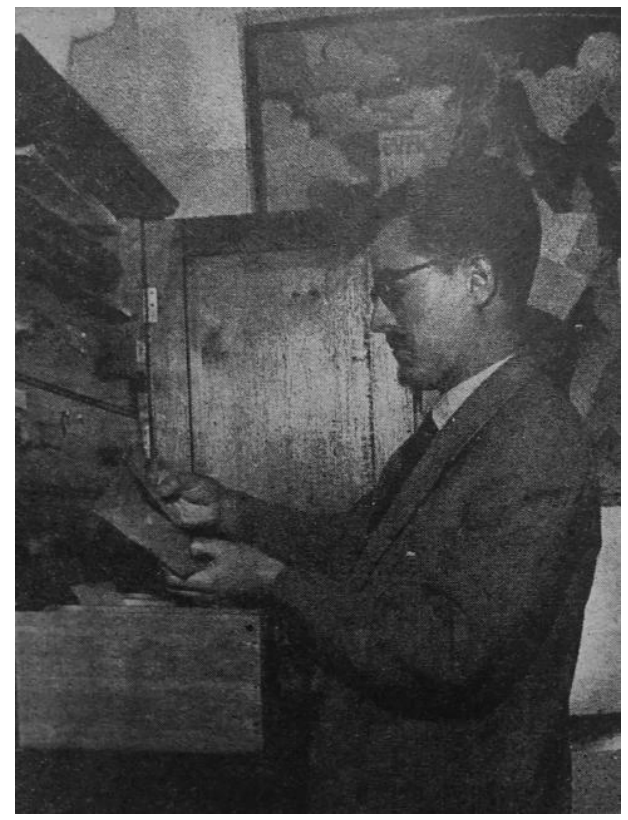



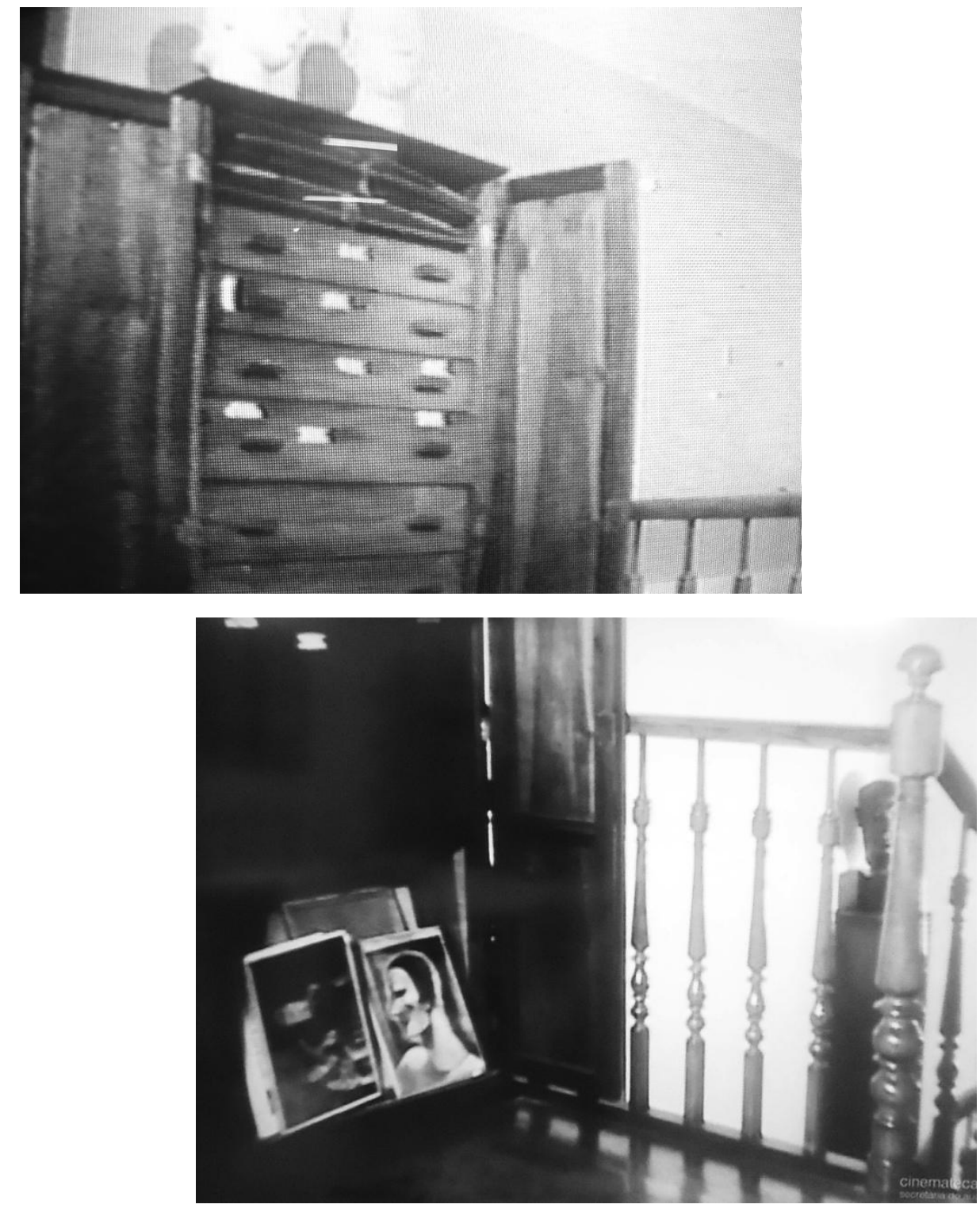

Imagem 88 e 89. Móvel para o fichário analítico, que acondicionava algumas telas e, possivelmente suas pastas de couro com papéis flexíveis.

Fonte: Casa de Mário de Andrade. SARNO, Geraldo (dir.); FARKAS, Thomaz (fot.). São Paulo: IEB USP, 1968. Fonte: A Casa de Mário de Andrade. SANTOS, Ruy (direção). São Paulo: Rangel Filmes Ltda, 1955.

Como antessala do seu estúdio, há um espaço que constitui um escritório para fora do estúdio do intelectual, possivelmente seria o local de trabalho de seu secretário, ou seria ainda uma sala de espera, ou seria apenas um cômodo sem uso definido. De qualquer maneira, já se vê a mão de Mário na exposição das obras ao olhar. 


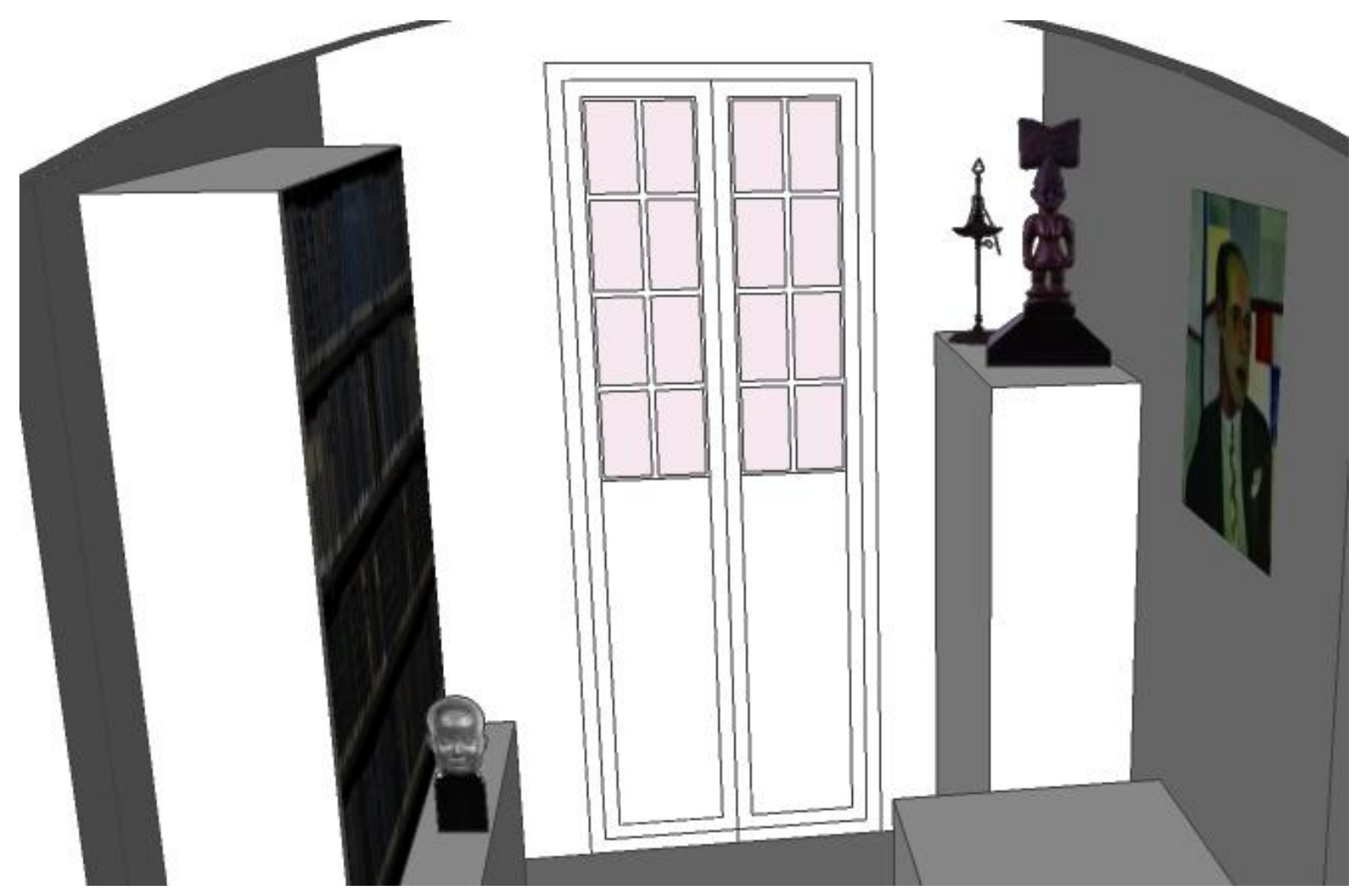

Imagem 90. Vista da antessala do estúdio.

Fonte: Maquete eletrônica da casa de Mário de Andrade. Camila Lacerda, 2012.

Este cômodo funciona como dar as boas vindas ao estúdio, ao introduzir o Retrato de Mário de Andrade como abre alas do ambiente de trabalho do escritor, como a unir o próprio retratado espaço interno ao mundo exterior.

A composição geométrica do fundo remete às composições com quadrados demarcados com linhas escuras, ora preenchidos em tons neutros, ora pelas cores primárias, azul, amarelo e vermelho. Sem dúvida, houve a assimilação, divulgação e implantação das vanguardas para dentro da coleção do modelo. A gravata remete mais uma vez a questão do Arlequim, como na capa Paulicéia Desvairada.

Para Mário de Andrade, esta obra foi realizada sem qualquer interferência sua, Segall

[...] pegou o que havia de perverso em mim, de pervertido, de mau de feiamente sensual. A parte do Diabo. (...) Às vezes chego a detestar, (me detestar) o quadro que o Segall fez.

E, mesmo assim, na contradição entre não gostar do quadro e a colocação de sua figura em pé de igualdade às vanguardas artísticas, Mário de Andrade expõe a obra ao olhar, não dentro de seu estúdio, mas próximo como a lembrá-lo de seu lado "diabólico" 70.

${ }^{70}$ SOUZA, Gilda de Mello e. Homenagem a Mário de Andrade: o colecionador e a coleção. In: BATISTA, Marta Rossetti e LIMA, Yone Soares de. Coleção Mário de Andrade. Artes Plásticas. São Paulo: IEB USP, 1984, p. XV. 


\section{Estúdio distribui os objetos}

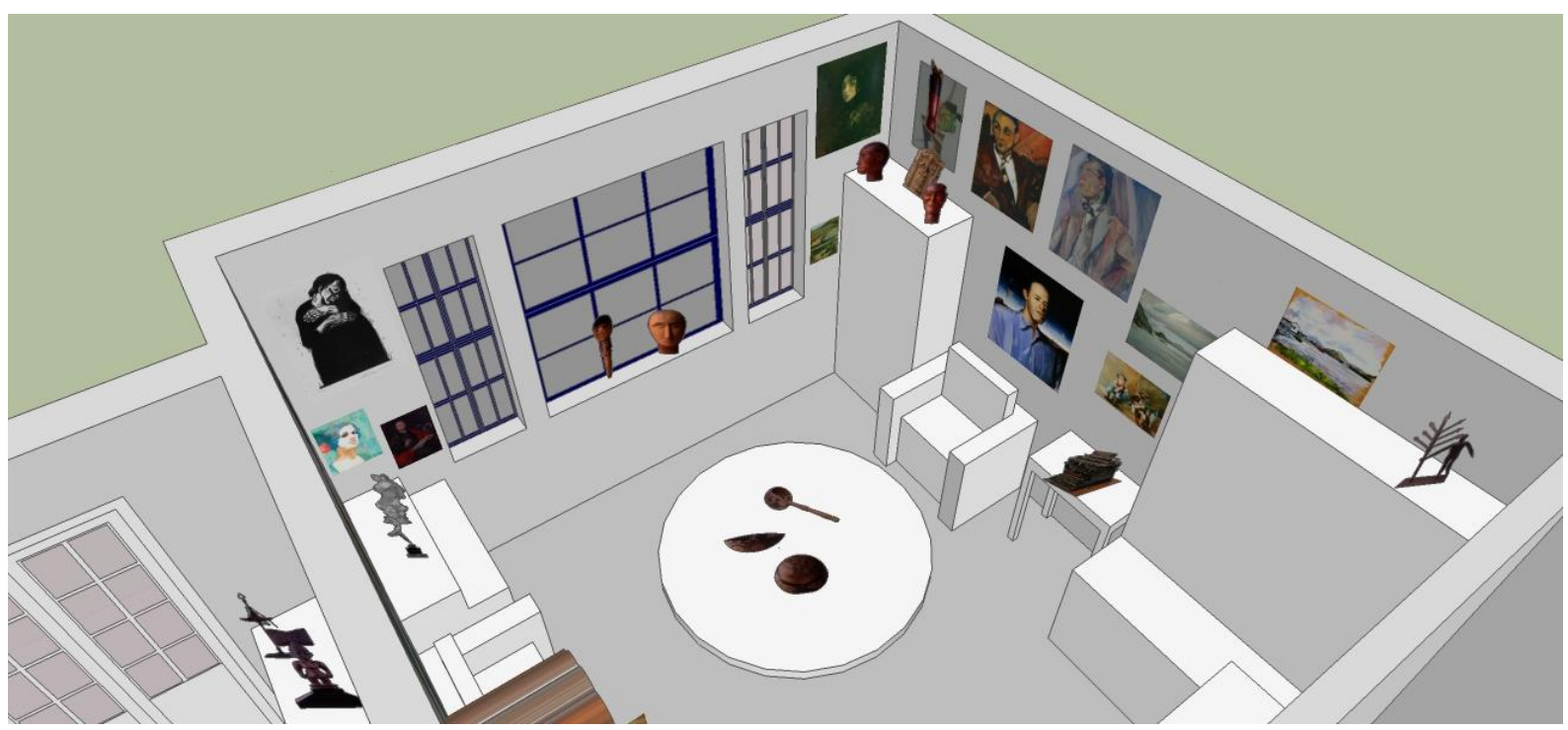

Imagem 91. Vista de quem entra para o estúdio.

Fonte: Maquete eletrônica da casa de Mário de Andrade. Camila Lacerda, 2012.

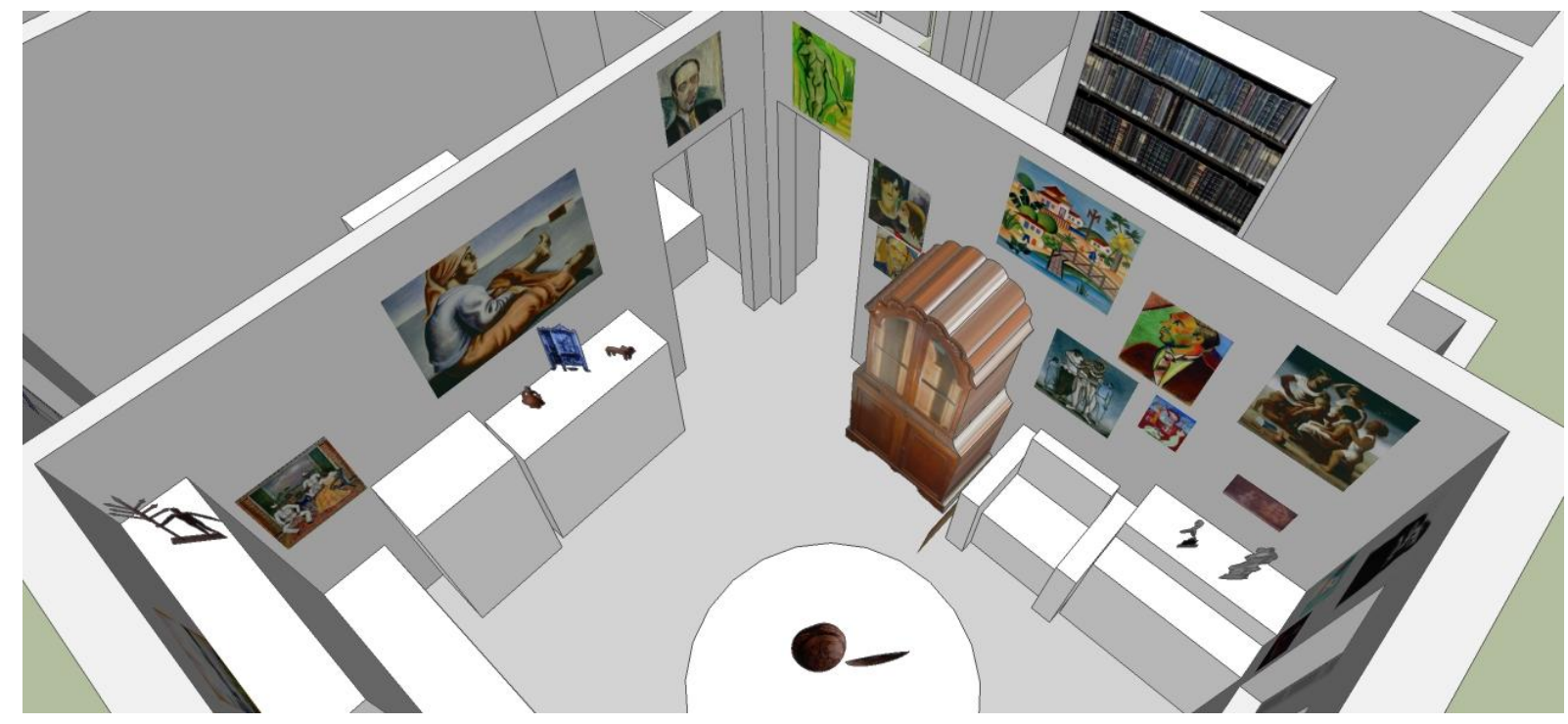

Imagem 92. Vistas para a porta do estúdio.

Fonte: Maquete eletrônica da casa de Mário de Andrade. Camila Lacerda, 2012.

As recordações de Zé Bento, em entrevista concedida nos anos 1990 a Roniwalter Jatobá, publicada na Revista Memória, revelam o cotidiano das atividades de Mário de Andrade, na casa da Lopes Chaves, a começar:

[...] às 7h30, o Mário já estava de banho tomado... ele gostava muito de usar robe de chambre, tinha um desenhado por ele mesmo... era assim que trabalhava... sentado na escrivaninha que foi do pai dele... muito metódico... tinha uma memória 
prodigiosa... várias vezes o surpreendi declamando Ahasverus e o Gênio, de Castro Alves ou então I Juca Pirama, de Gonçalves Dias. ${ }^{71}$

Em muitas das entrevistas reunidas pela Prof. Telê Ancona Lopes, os depoimentos dos repórteres explicitam as sensações causadas pela casa, em especial ao estúdio de Mário de Andrade, possivelmente local que recebia seus convidados e visitas ${ }^{72}$. Corrobora com o recebimento dos convidados no estúdio, a experiência do Prof. Antonio Candido quando fora a primeira vez na Lopes Chaves. Em companhia de Paulo Duarte, Mário de Andrade os recebera em seu estúdio, mostrando-Ihes um livro dito de "luxo", com capa elaborada danificada pelos Correios ao violar a embalagem ${ }^{73}$.

As impressões registradas por Francisco de Assis Barbosa, quando fora conversar com Mário de Andrade, é a de:

[...] uma casa simples, sem luxo. Mas está cheia de quadros, de livros, de músicas. Lhote, Picasso, Portinari, Segall. Sem falar na coleção de desenhos e gravuras, que sobem a oitocentos mais ou menos. E os livros? Há de tudo. A parte principal é sobre arte e literatura. As músicas estão em baixo, numa sala pequena, que tem o retrato de Beethoven. Sei que existem para mais de vinte mil peças, todas devidamente catalogadas na biblioteca de Mário de Andrade ${ }^{74}$.

Em outra entrevista concedida, dessa vez a Mário da Silva Brito, em 1943, o crítico literário registra as seguintes sensações despertadas, "ambiente acolhedor da casa de Mário: quadros de Portinari, de Segall e de Tarsila, pastas de artigos, revistas, álbuns de arte, recortes de jornal e mil e uma outras coisas. E um bem-estar com visgo" ${ }^{75}$.

O colecionador ainda menciona seus hábitos ao escrever, entre eles o de sentir a Manuela, sua máquina de escrever, e fumar:

Quando escrevo fumo constantemente os fumos fortes do meu país. Odeio os fumos preparados europeus. E bebo muito café, bem forte, à maneira paulista. Adoro o café e o fumo.

\footnotetext{
${ }^{71}$ Mário de Andrade e José Bento Ferraz - Angelo Mendes Corrêa, texto que reproduz a trecho da entrevista concedida a Roniwalter Jatobá, nos anos de 1990. Disponível em <http://www.verbo21.com.br/v5/ index.php?option=com_content\&view=article\&id=362:mario-de-andrade-e-jose-bento-ferraz-angelo-mendes - correa\&catid=64:resenha-e-ensaios-junho-2011\&Itemid=127>. Acesso em 05 fev. 2012.

72 ANDRADE, Mário de. Entrevistas e depoimentos. Telê Porto Ancona Lopez (org.). São Paulo: T. A. Queiroz, 1983, p. 102.

${ }^{73}$ Depoimento de Antonio Candido, a A. em 27 out. 2011. Este livro vem a ser ALIGHIERI, Dante. Vita nuova. Nel sesto centenario della morte di Dante Alighieri. Bergamo: Instituto Italiano D'arti Grafiche, 1921. Coleção Mário de Andrade - Biblioteca do Instituto de Estudos Brasileiros da USP., número de chamada MA094 D192v. O livro vem dentro de uma caixa, que juntamente com a capa, foi extremamente danificada.

${ }^{74}$ É interessante notar o interesse do jornalista revela sua cultura bibliófila, mesmo que cite a coleção de arte. ANDRADE, Mário de. Entrevistas e depoimentos, op. cit., p. 102.

${ }^{75}$ Ibidem, p. 93.
} 
Não tenho nenhum cacoete nem característica quando escrevo, a não ser, encostar de vez em quando a testa no metal da máquina de escrever, e sentir-lhe o friozinho. Também, às vezes, quando o escrito sai com lentidão, acaricio a máquina com a mão direita, como quem passa a mão num cavalo para amansá-lo. Tenho procurado me consertar desse animismo exagerado, mas não consigo. Detesto jogar cinza no chão, tenho perto de 30 cinzeiros em meu estúdio, e as próprias poltronas dele, desenhadas por mim, cada uma tem um cinzeiro incrustado nela. Jogo porém cinza nas peles de onça $^{76}$ que trouxe das minhas viagens, porque isso lhes faz bem. $^{77}$

O próprio Mário se refere ao estúdio em $O$ Banquete quando, pela personagem Siomara Ponga, diz ter obtido

[...] um quadro de Anita Malfatti, o famoso Homem amarelo, que causou aquela briga danada na exposição que ela fez em São Paulo, em 1917. Tenho ele no meu estúdio. Mas esse é pintura verdadeira, e si não o observo todos os dias e às vezes o olho sem ver, a sensação estética permanece e revive toda a vez que contemplo o quadro ou penso nele ${ }^{78}$.

Neste livro, mais uma vez o autor insere personagens colecionadores, um é Sarah Light que reúne "coleção de orquídeas e avencas" e outro Féliz de Cima, político da cidade de Mentira que,

[...] não queria saber de quadros nem de estátuas no apartamento, só gravuras pornográficas, e como os artistas, depois de comprado o quadro do governo, presenteavam com uma tela bem grátis o protetor das artes, Félix de Cima, descobriu a generosidade. Mandava tudo para a Pinacoteca de Mentira. Só guardou um quadrinho, porque esse era muito precioso, diziam, uma vênus angelina, em estilopersa, vinda dum salon de Paris e que era atribuída a Raffaello Sanzio.

Como nos revela Chagas, Mário de Andrade já identificava pelo menos dois tipos de colecionadores um com "dimensão cultural e humana", outro alienado e egocêntrico.

76 Nenhum dos registros pesquisados até aqui encontro qualquer dos tapetes trazidos de suas viagens etnográficas.

77 ANDRADE, Mário de. Entrevistas e depoimentos. Telê Porto Ancona Lopez (org.). São Paulo: T. A. Queiroz, 1983, pp. 41-42.

${ }^{78}$ A voz é mais uma vez da personagem Siomara Ponga. ANDRADE, Mário. O Banquete. São Paulo: Duas Cidades, 1977, p. 90. 


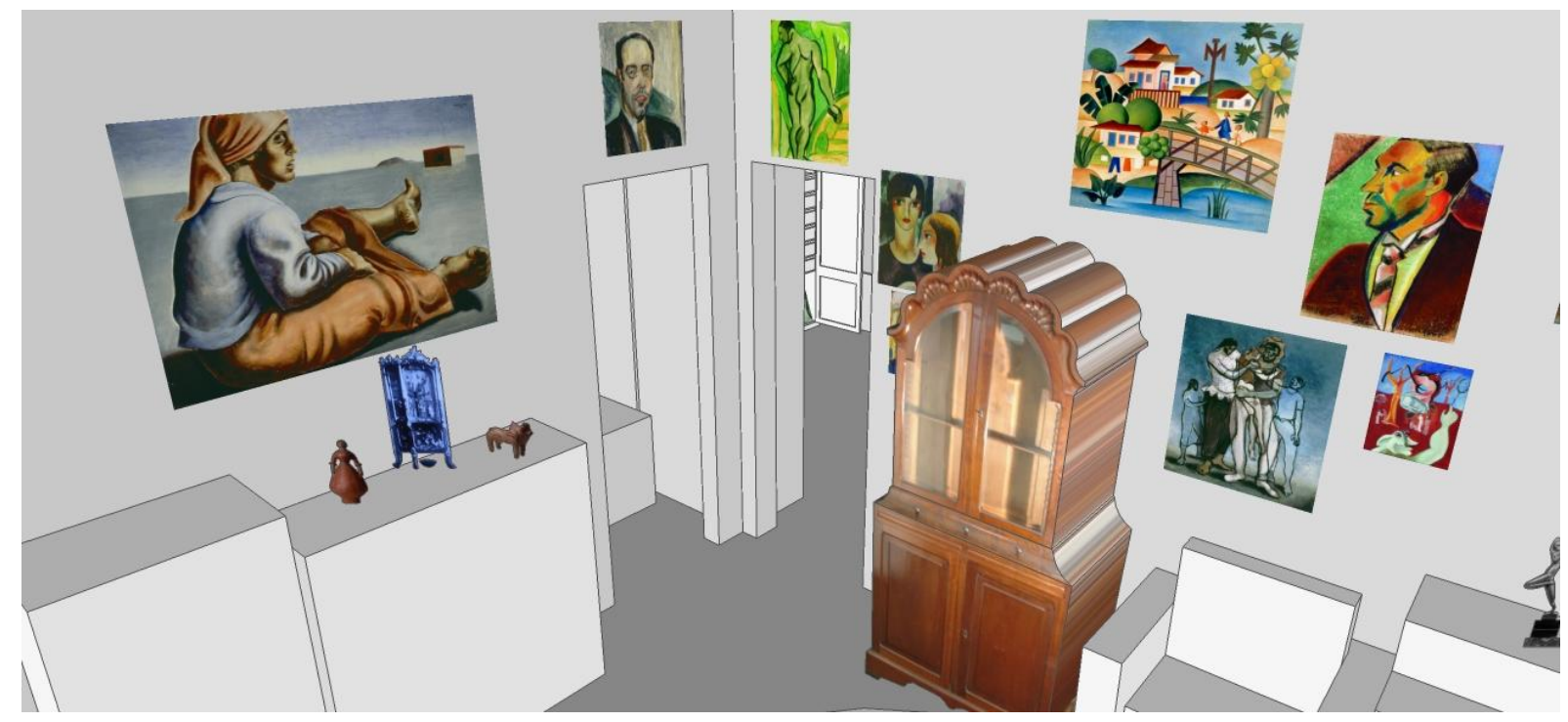

Imagem 93. Vista do estúdio.

Fonte: Maquete eletrônica da casa de Mário de Andrade. Camila Lacerda, 2012.

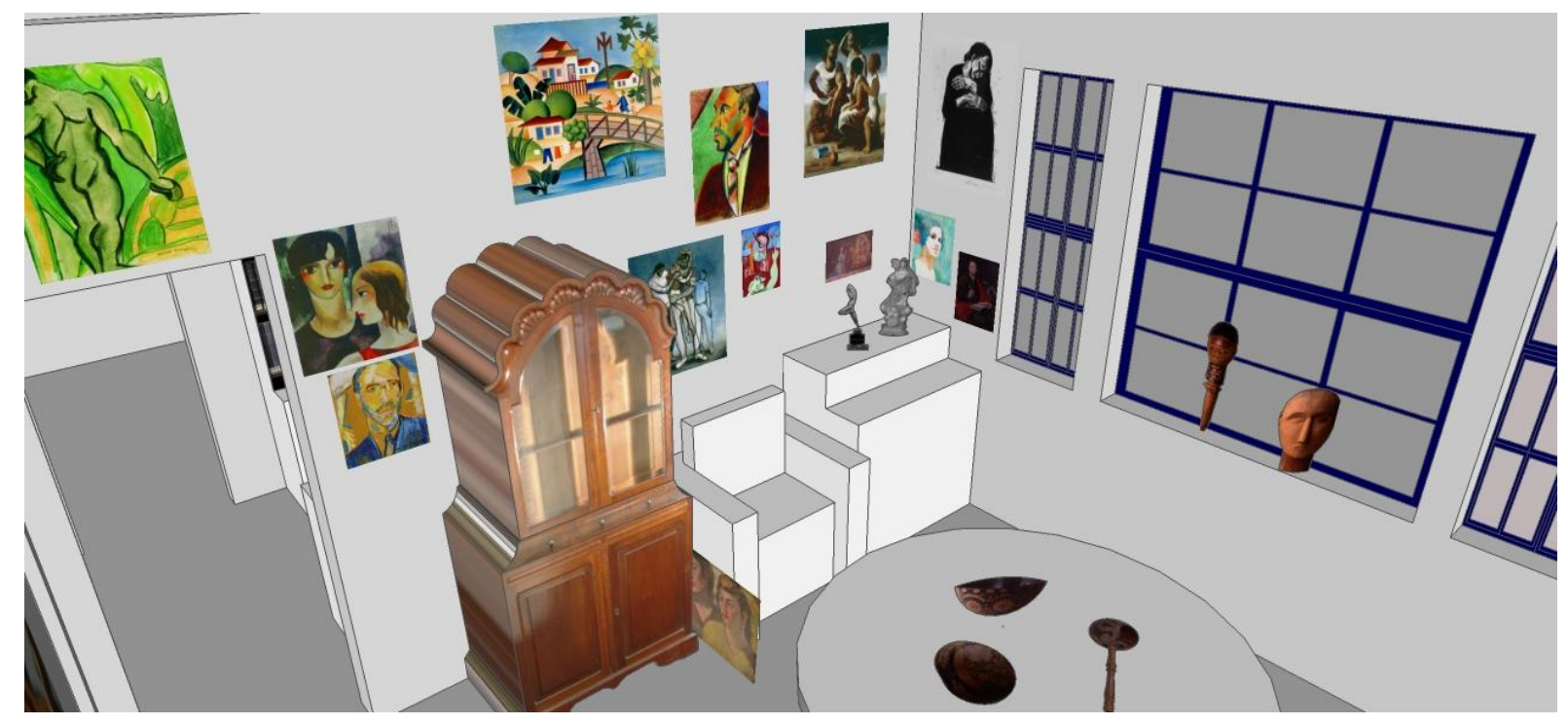

Imagem 94. Vista do estúdio.

Fonte: Maquete eletrônica da casa de Mário de Andrade. Camila Lacerda, 2012. 


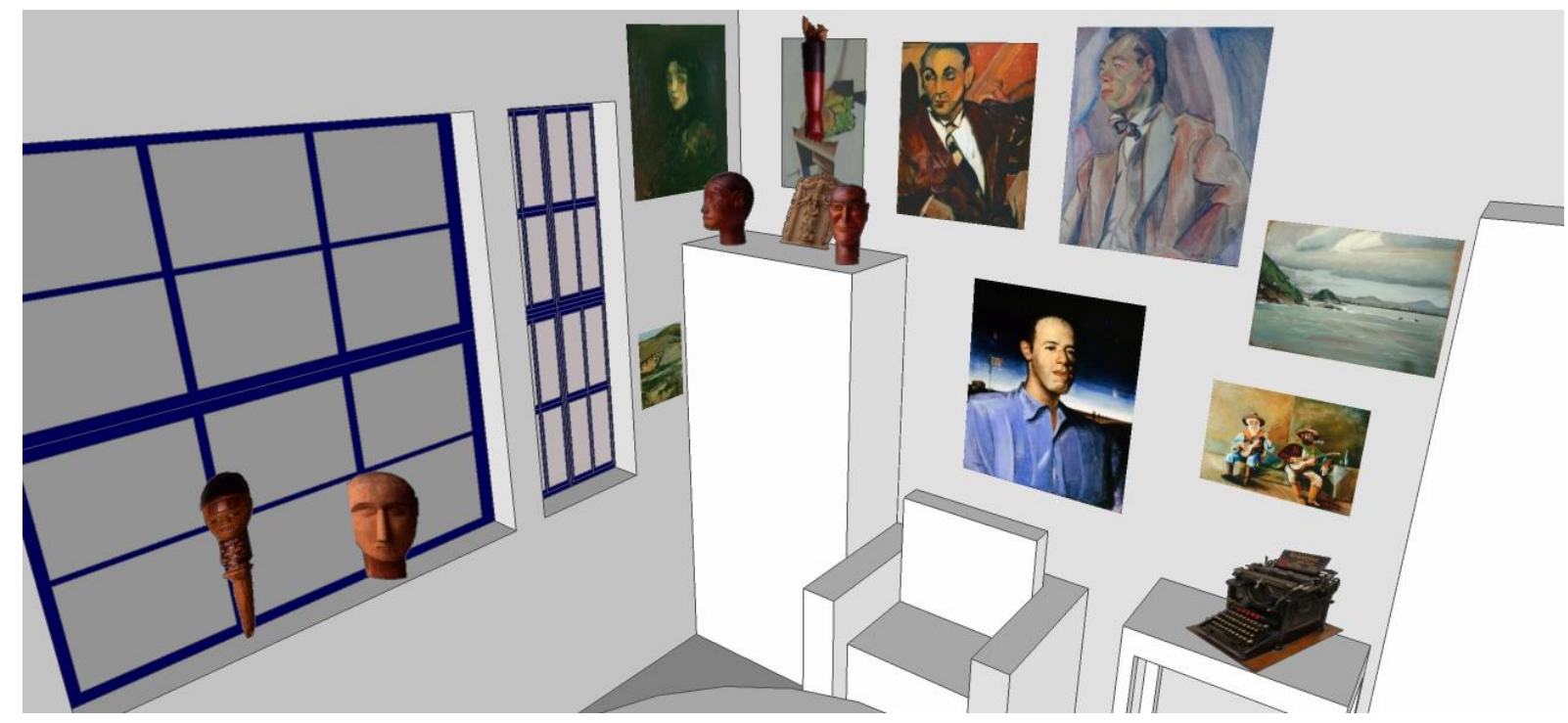

Imagem 95. Vista do estúdio.

Fonte: Maquete eletrônica da casa de Mário de Andrade. Camila Lacerda, 2012.

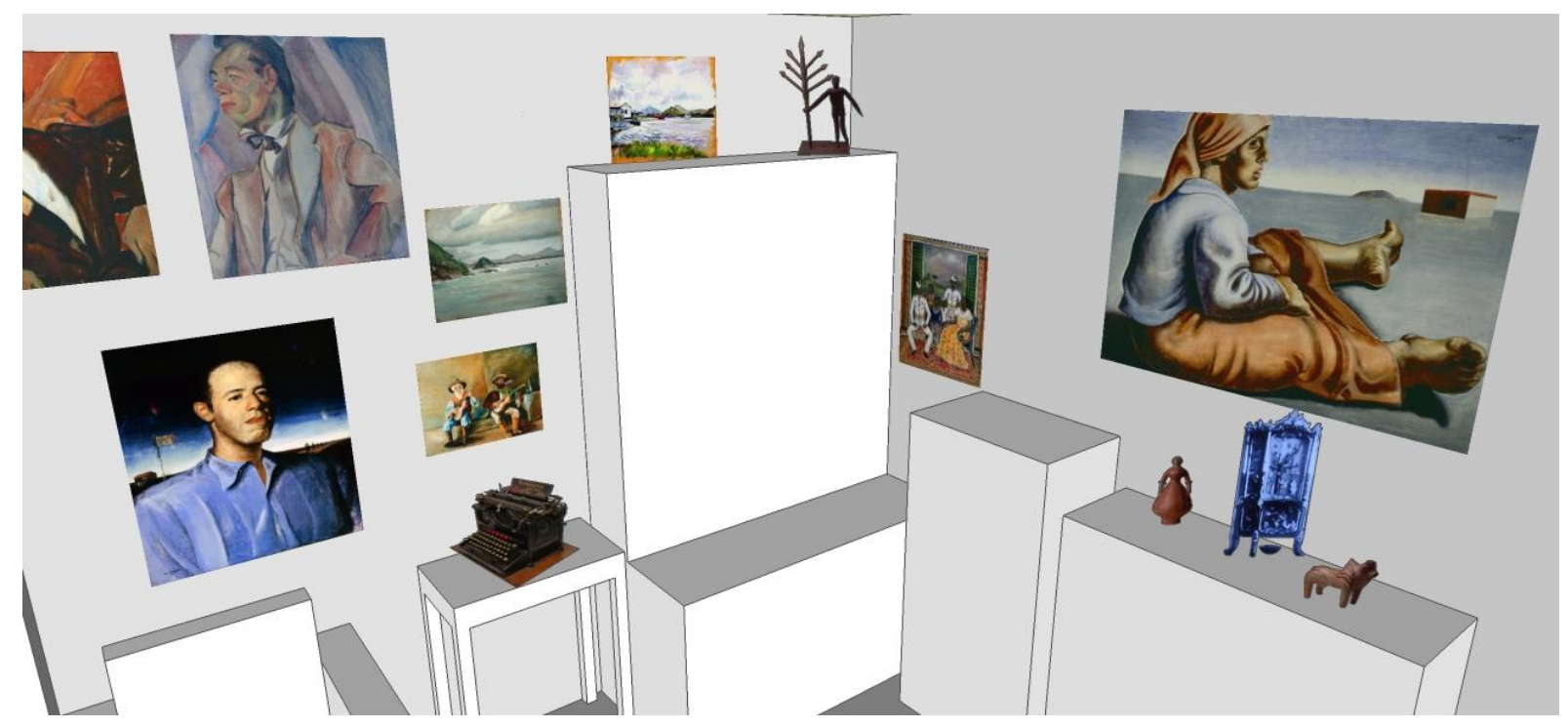

Imagem 96. Vista do estúdio.

Fonte: Maquete eletrônica da casa de Mário de Andrade. Camila Lacerda, 2012.

É ainda Francisco Barbosa A entrevista, concedida de Francisco a Assis Barbosa, em 1944, por Mário de Andrade, revela que vira "pela primeira vez, os quadros de Anita Malfatti: $O$ homem amarelo e $A$ estudante russa, que tanta celeuma provocaram nos áureos tempos do modernismo" ${ }^{7980}$. Estas obras foram tratadas com naturalidade pelo repórter, sem qualquer vestígio do escândalo causado em 1917, o que Mário infere:

${ }^{79}$ CHAGAS, Mário. Museu, literatura e emoção de lidar. CADERNOS DE SOCIOMUSEOLOGIA, 19: 5-34, 2002, p. 20. 
Você acha normal, não é? Isso quer dizer que não fizemos o modernismo em vão. Para a época, $O$ homem amarelo era uma coisa louca. Poucos compreenderam, quase ninguém aceitava. Anita é uma pioneira ${ }^{81}$.

A Prof.a Gilda Souza trata da exposição dos objetos ao olhar:

Quando se volta à casa examina a colheita, sente-se seguro e compensado. Finalmente, vê desenhar à sua volta um mundo concreto, estável, sujos segmentos pode examinar cuidadosamente, comparar, colocando-os um ao lado do outro. Olha demoradamente a coleção, não apenas o que acabou de recolher, mas o que há algum tempo vem juntando e luga-se, quer ao seu interesse pelo Braisl, quer à grande virada artística do modernismo: são livros, revistas, gravuras, partituras musicais, quadros - enfim, uma infinidade de 'testemunhos-lembranças' de um passado remoto ou recente, que agora repousam na 'calma sapientíssima' do estúdio. Está ali, bem protegido, o mundo de que necessita: dócil, ordenado, ao alcance da mão e do olhar. Já não é preciso travar a cada passo o duro corpo a corpo com as coisas, com o outro, com o real; agora basta ficar atento aos sinais e desentrenhar das formas, das estruturas, as complexas relações de significação. Pois não acumulou visando o lucro, como um marchand, ou status, como um novo rico, mas para chegar mais perto do Homem e do mundo. Para que um dia, olhando a coleção, ele se reconhecesse, pudesse refazer o grande puzzle de sua vida, de sua época. 0 colecionador descansa na coleção ${ }^{82}$.

Contíguo ao estúdio está o quarto de Mário de Andrade, cuja entrada, provavelmente, é exclusiva por este. Esta pesquisa não encontro muitos registros deste espaço, limitou-se a apenas uma tomada do filme de 1968. Segundo depoimento de Antonio Candido fora o local em que Mário passara seus últimos momentos.

\footnotetext{
80 Possivelmente o entrevistador equivocara-se ao ver juntos, num mesmo cômodo, $O$ home amarelo e $A$ estudante russa. Ibidem, p. 41.

81 Ibidem, p. 42.

${ }^{82}$ SOUZA, Gilda de Mello e. O colecionador e a coleção. In: BATISTA, Marta Rossetti e LIMA, Yone Soares de, op. cit., pp. XV-XVI.
} 


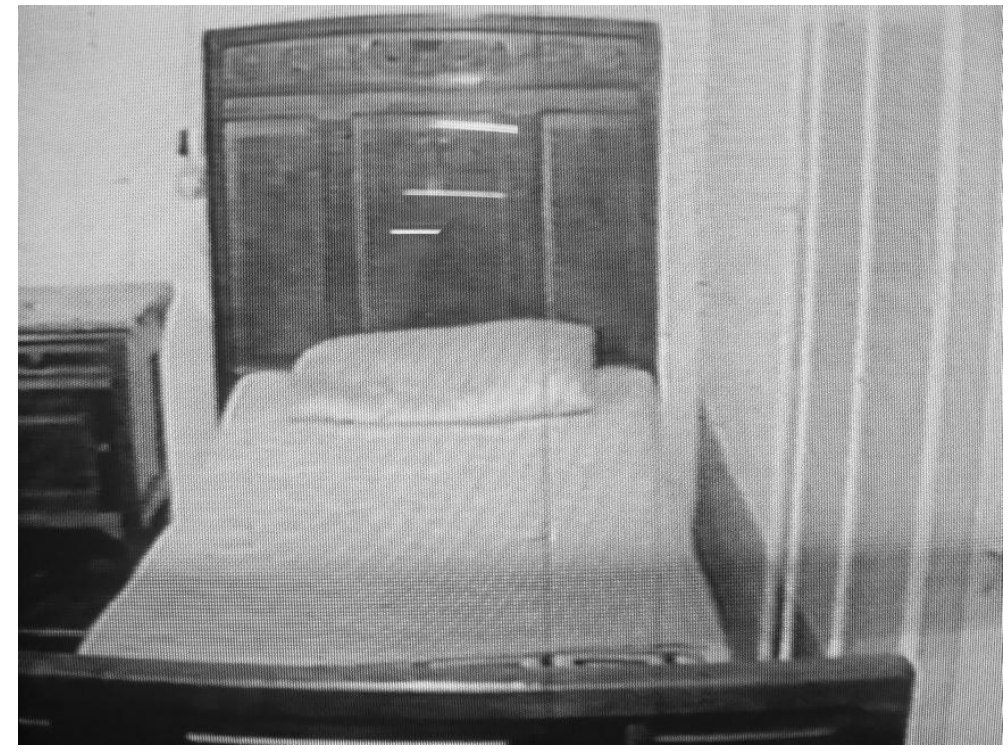

Imagem 97. Vista da cama no quarto de Mário de Andrade.

Fonte: Casa de Mário de Andrade. SARNO, Geraldo (dir.); FARKAS, Thomaz (fot.). São Paulo: IEB USP, 1968.

\section{Mário como fruidor de suas coisas da terra}

Consciente de seu papel na história de seu tempo, Mário de Andrade construiu uma imagem pública e dentro de padrões, possivelmente numa concepção que seria considerada como ideal para ele, diferentemente de outros, como Oswald de Andrade, para quem a dedicação ao coletivo e o retrato em si passaram por outras especificidades. As fotografias em que Mário posa junto a suas obras revelam o binômio: imagem pública $X$ imagem privada, nas quais aparece sua postura em ocasiões sociais ou em situações privadas.

Para Mário, a coleção parece funcionar como um alento para os males da alma, conforme escreve a Pio Lourenço, em 10 de outubro de 1938, "quando estou só comigo, e não me sinto completo, e me falta tal livro ou tal parte das fichas, ou não posso me reconhecer no passado em que adquiri tal quadro, me faço uma enorme falta a mim mesmo, me sinto amputado, desmusculado, intelectualmente anêmico" ${ }^{83}$.

${ }^{83}$ PIO \& MÁRIO: diálogo da vida inteira. A correspondência entre o fazendeiro Pio Lourenço Corrêa e Mário de Andrade. Antonio Candido (traços biográficos). Gilda de Mello e Souza (introd.) Denise Guaranha (texto e notas). Tatiana Longo Figueiredo (texto, datas e revisão ortog.). Rio de Janeiro / São Paulo: Ouro sobre Azul / SESC-SP, 2009, p. 318. 


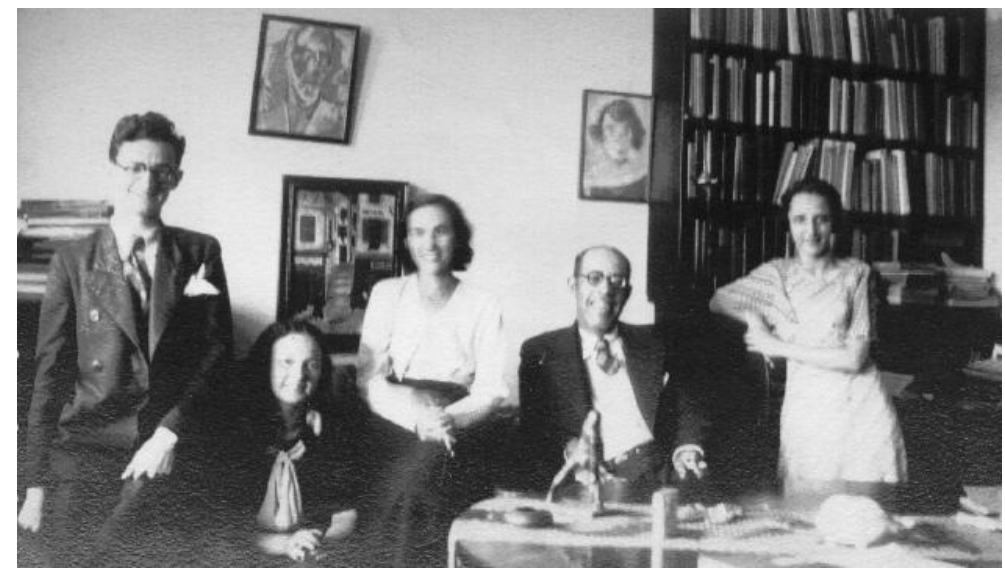

Imagem 98. Mário de Andrade fotografado, em seu estúdio, entre seus alunos: Carlos Ostronoff, Sônia Stermann e Oneyda Alvarenga, [1934].

Fonte: Fotografia do Fundo Mário de Andrade - Arquivo do Instituto de Estudos Brasileiros da USP.

Na foto acima, provavelmente de 1934, Mário de Andrade está vestido de terno em seu escritório rodeado por alunos, local que se percebe já possui a escrivaninha, à direita, e a mesa redonda ao centro. A disposição dos quadros, anterior ao que deixara em 1945, permite observar a obra Nice de Joaquim Vicente Monteiro, e dois retratos de Anita Malfatti, um o seu próprio e outro do poeta, ambos realizados em pastel no mesmo ano da Semana de Arte Moderna.

O seu estúdio ainda servia como refúgio, local em que encontrava retiro nas suas coisas da terra:

Ontem, domingo, foi espantoso, não fiz nada de nada por dezoito horas a fio! É engraçado: nos momentos de dores profundas, fico de uma calma enorme e gosto de me banhar e vestir bem. Levei mais de duas horas no banho, fiz uma barba de bundinha de criança, uma lisura irrreprochável. Depois me perfumei com unção e botei um pijaminha de seda listrada, o mais lindo da minha vida. E sentei no estúdio. Olhava pras coisas boas, de repente levantava e mudava uma terracota do Brecheret dois centímetros mais para o lado direito. Trocava dois quadros, pregava outro na parede, e depois sentava quatro vezes dos quatro cantos do estúdio, pra ver o efeito das mudanças ${ }^{84}$.

Neste trecho, o poeta revela a movimentação da sua coleção, seja de poucos centímetros que podem alterar a proporção da exposição ao olhar, seja de lugar na casa, afinal os registros póstumos situam a terracota de Brecheret na sala de visitas. Parece que

${ }^{84}$ Carta a Rodrigo Mello Franco de Andrade, 23 maio 1938. In: ANDRADE, Mário. Cartas de trabalho: correspondência com Rodrigo Mello Franco de Andrade (1936 - 1945). Brasília: Ministério da Educação e Cultura, 1981, p. 131. 
além de colecionador, Mário de Andrade assume uma postura do que, hoje, denomina-se como curador.

Ontem enfim, passei o dia rearranjando este meu estúdio, e coloquei a Colona sentada e a Composição nas paredes. Ficou tão lindo que passei o dia todinho no quarto, gostando de viver, olhando os quadros, os marfins, num silêncio amoroso, cheio de belezas companheiras ${ }^{85}$.

No sentido de buscar os movimentos da coleção, são interessantes as escolhas e a exposição de Mário, quando estava exilado no Rio de Janeiro. Há uma série de fotografias, nas quais o poeta posa de robe de chambre junto a sua coleção, tiradas em seu apartamento da Glória, no ano de $1938^{86}$. De apenas posse destes elementos, entretanto, não foi possível reconstituir os cômodos, como no caso da Rua Lopes Chaves.

Em carta a Zé Bento, datada de 10 de agosto de $1938^{87}$, Mário explicita a vontade de levar para o Rio de Janeiro as seguintes obras:

$\infty$ seu Retrato realizado por Lasar Segall,

$\infty$ Mamoeiro de Tarsila do Amaral,

$\infty$ Família do fuzileiro naval de Alberto da Veiga Guignard,

- Composição (Retirantes) de Cândido Portinari,

$\infty$ Nossa Senhora do Carmo antiga,

¿ São João Evangelista antigo,

$\infty$ A Colona também de Portinari,

- o Oxê de Xangô,

$\infty$ a Cabeça de Cristo de Victor Brecheret e, por fim,

$\infty$ seu altarzinho antigo.

Comparando essa lista com o material iconográfico, observa-se que não há poses em que apareçam: A familia do fuzileiro naval, Composição (Retirantes), Nossa Senhora do Carmo e Cabeça de Cristo. Em contrapartida, existem: Retrato de Mário de Andrade, escultura de Joaquim Figueira, Descida da cruz de Antônio Gomide, Soirée de família de Noêmia Mourão e Cabeça de negro, escultura de Ricardo Cipicchia, mais seu harmônio e de outros objetos pertencentes à série religião e magia / música e dança / cotidiano: Cristo na coluna, bastão antropomorfo, Oxê de Xangô, Rei Mago em papier maché e duas cabeças de

${ }^{85}$ Carta a Cândido Portinari, 1938. In: ANDRADE, Mário de. A imagem de Mário: textos extraídos da obra de Mário de Andrade / [introdução, Telê Porto Ancona Lopez]. Rio de Janeiro: Edições Alumbramento, 1984, p. 164.

${ }^{86}$ Agradeço imensamente a generosa oferta de Antonio Candido, que me dera de presente o livro PIO \& MÁRIO: diálogo da vida inteira no qual há a identificação destas imagens, que há muito me intrigavam por não bater com a Lopes Chaves. Conforme pesquisa que reúne as cartas trocadas entre Mário de Andrade e Pio Lourenço, foram imagens realizadas em 1938, quando Mário já havia se mudado para o Rio de Janeiro. In: PIO \& MÁRIO: diálogo da vida inteira. A correspondência entre o fazendeiro Pio Lourenço Corrêa e Mário de Andrade. Antonio Candido (traços biográficos). Gilda de Mello e Souza (introd.) Denise Guaranha (texto e notas). Tatiana Longo Figueiredo (texto, datas e revisão ortog.). Rio de Janeiro / São Paulo: Ouro sobre Azul / SESC-SP, 2009, pp. 315-318.

${ }^{87}$ Correspondência de Mário de Andrade a José Bento Ferraz, Rio de Janeiro, 10 de agosto de 1938. Fundo José Bento Ferraz - Arquivo IEB USP. 
ex-votos; além de um mapa do Brasil Meridional ${ }^{88}$, que curiosamente fora mantido fora das séries tradicionais: artes plásticas, objetos religiosos e populares e objetos ligados a Revolução Constitucionalista de 1932.

A foto abaixo está Mário de Andrade em sua mesa de trabalho com diversos elementos típicos de escritório, como bloco de anotações, tinteiro, mata borrão, entre outros. Assim, nesse ambiente, o uso de robe de chambre fica contraditório, o que explicita ser cenas intencionalmente construídas. Destaca-se $A$ colona de Portinari, deliberadamente exposta ao olhar a coroar sua atividade intelectual solitária, dessa maneira a figura solitária Ihe faria companhia nas horas de labuta e de elaboração de correspondência para destinatários em São Paulo. Ou ainda seria companheira de infortúnio com intuito de apaziguar sua dor, durante o período em que permanecera no exílio voluntário.

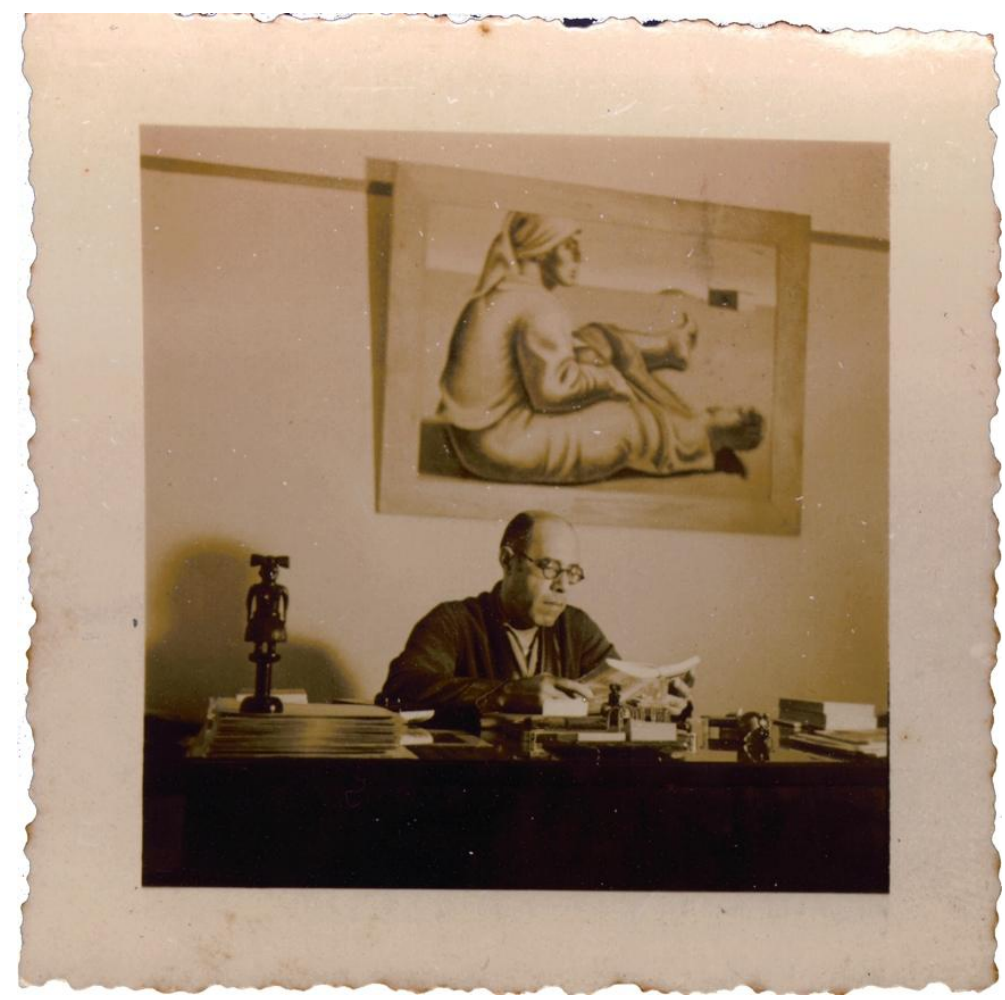

Imagem 99. Mário de Andrade e A colona, de Cândido Portinari, no apartamento da Glória, RJ, 1938.

Fonte: Fotografia do Fundo Mário de Andrade - Arquivo do Instituto de Estudos Brasileiros da USP.

Em contraposição à sua mesa de trabalho, o lugar do deleite, do descanso, do repouso: o divã com O mamoeiro de Tarsila do Amaral. Nesta pose, Mário de Andrade revela o prazer de ler uma revista, de fumar seu cigarro, confortavelmente acomodado com as pernas recolhidas sobre o divã e cercado por almofadas. Mais do que mitigar os desconfortos possíveis do mobiliário, estes elementos decorativos individualizam a casa ${ }^{89}$, como as almofadas de Mário, possivelmente da artista Regina Gomide Graz, dedicada às obras de

${ }^{88} \mathrm{Na}$ legenda, possivelmente: “Mappa Geographica Regni Brasiliæ in America Meridional, maxime celebria accuratæ delineata per Matth Seutterum Sac. Cas. Maj. Geogr. Auguste Vind".

${ }^{89}$ CARVALHO, Vânia Carneiro de. Gênero e Artefato: o sistema doméstico na perspectiva da cultura material São Paulo, 1870-1920. São Paulo: Edusp / FAPESP, 2008, p. 99. 
arte têxteis. Esta composição é assemelhada à Casa Modernista de 1930: divã, almofadas, tela de Tarsila do Amaral emoldurada por Pierre Legrain, de modo que Mário de Andrade levou, ao Rio, as transformações estéticas desbravadas por São Paulo.

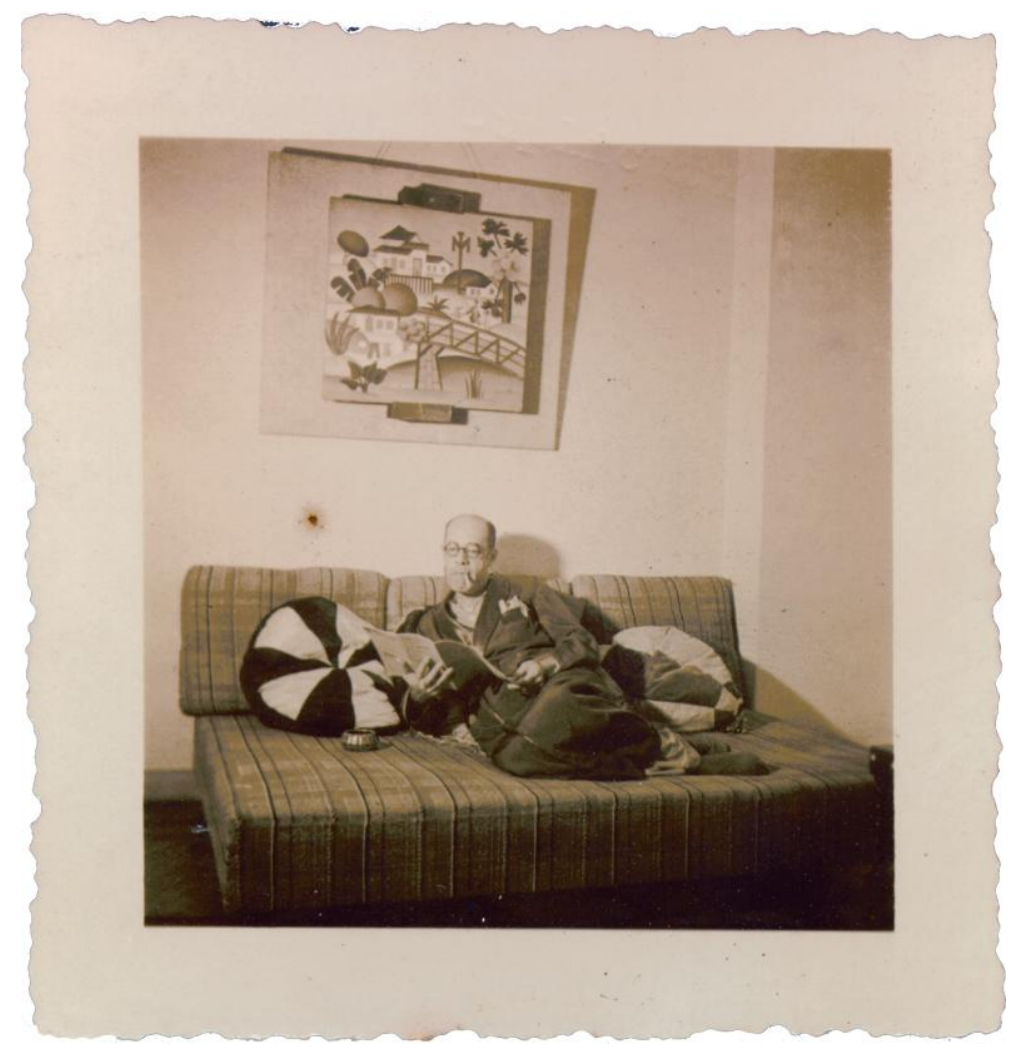

Imagem 100. Mário de Andrade e O mamoeiro, de Tarsila do Amaral, no apartamento da Glória, RJ, 1938.

Fonte: Fotografia do Fundo Mário de Andrade - Arquivo do Instituto de Estudos Brasileiros da USP.

Mário de Andrade, quando vai para o Rio, não se esquece de seu lado ligado à musica. Mais uma vez dispõe o seu harmônio com Soirée de família de Noêmia Mourão, talvez a temática do recital de música numa sala, sobreponha-se a qualquer elemento como grandeza da obra, ou mesmo da artista.

À direita do harmônio, está seu retrato realizado por Lasar Segall ${ }^{90}$, revela a assimilação, a divulgação e a implantação das vanguardas pelo colecionador, mesmo que não seja seu retrato predileto ${ }^{91}$. A gravata geométrica seria mais uma referência ao Arlequim, recorrente em sua coleção, ou na Paulicéia Desvairada? Este arranjo deixa patente a associação de seu lado professoral, ligado à música, com a reverificação da Inteligência nacional empreendida pelo movimento modernista.

\footnotetext{
${ }^{90}$ Em correspondência a Portinari, Mário de Andrade revela que sua mãe "pediu pra ficar com ela, pra ele poder olhar o filho". In: Portinari, amico mio: cartas de Mário de Andrade a Portinari. FABRIS, Annateresa (org.). Campinas / Rio de Janeiro: Mercado de Letras, Autores Associados / Projeto Portinari, 1995, p. 70.

${ }^{91}$ A preferência de Mário vai ao encontro do gosto de sua mãe.
} 

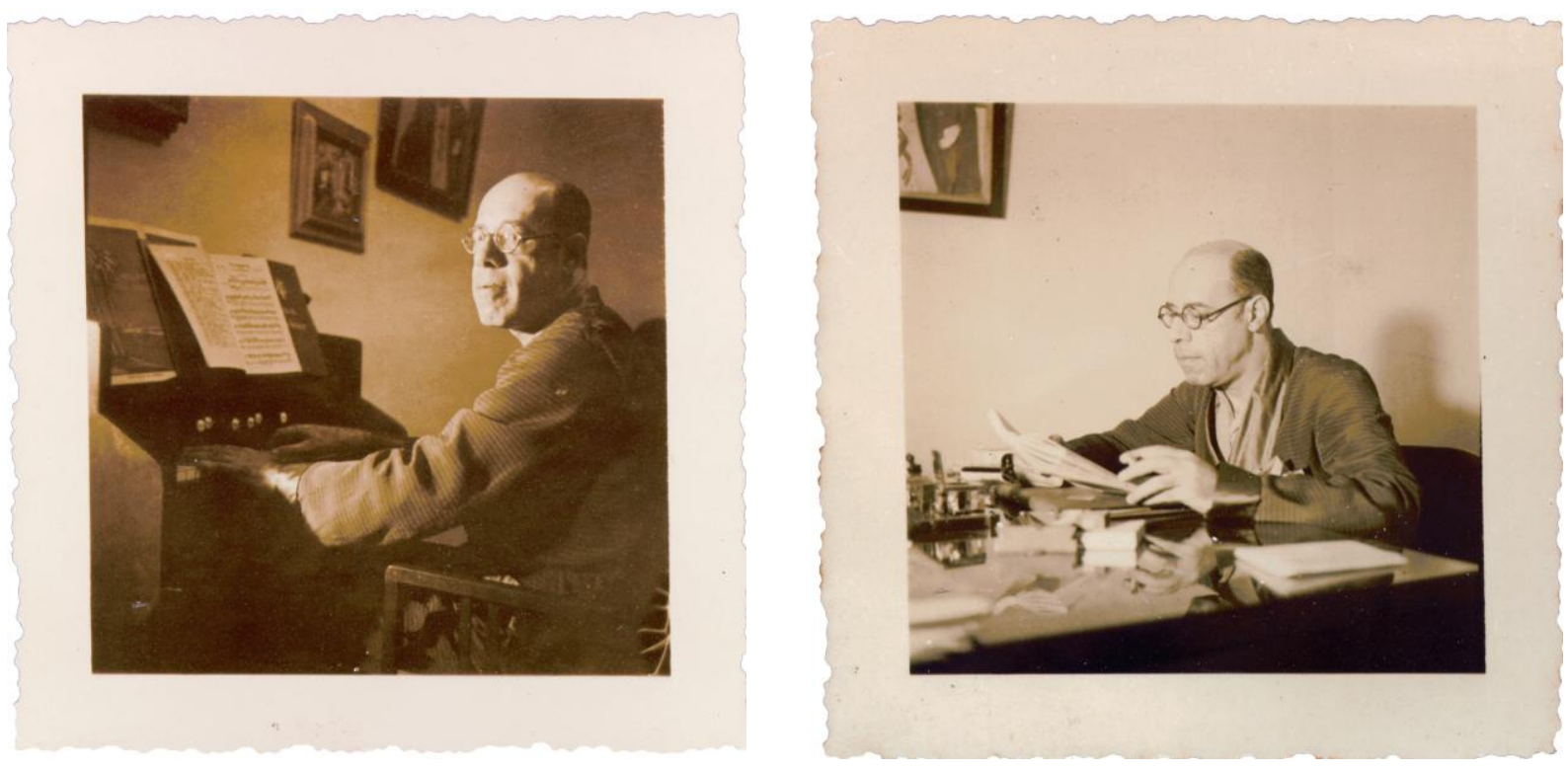

Imagem 101. Mário de Andrade e as obras Soirée de família de Noêmia Mourão e seu Retrato por Lasar, no apartamento da Glória, RJ, 1938.

Imagem 102. Mário de Andrade em sua mesa de trabalho, em que à esquerda está seu Retrato por Lasar, no apartamento da Glória, RJ, 1938.

Fonte: Fotografia do Fundo Mário de Andrade - Arquivo do Instituto de Estudos Brasileiros da USP.

Em todas as fotos de Mário de Andrade no Rio de Janeiro, a pose para a máquina fotográfica foi estabelecida previamente, seja pela exposição ao olhar das obras, seja indumentária, seu robe de chambre com gola e punhos de cetim brilhante; tudo a construir sua imagem pública de intelectual, colecionador, paulista, músico e participante ativo da Semana de Arte Moderna. Além disso, as suas companhias do Rio o cercavam como a mitigar os momentos de dor.

\section{Indumentária de Mário e a construção do homem público}

Nas fotos apresentadas anteriormente, é possível observar a importância que o poeta dava ao seu vestuário. Seja na composição tipicamente masculina: paletó, colete, calça, sapato e chapéu; seja no seu pijama de seda listrado, possivelmente confeccionado por sua mãe, assim como robes de chambre, conforme nos revela a Prof.a Gilda: "a mãe, Ihe confeccionava os lindos blusões de seda, lisos ou listados, que no verão usava em casa, sobre a camisa com gravata" 92 . Havia ainda os itens de tricô que ficavam a cargo da madrinha, manufaturando as idealizações de Mário "com elaborados desenhos geométricos, exigindo um cálculo rigoroso no número dos pontos, na combinação apurada de cores e matizes, indicações que ele especificava detalhadamente nos moldes e deviam ser seguidas à risca" ${ }^{93}$.

92 SOUZA, Gilda de Mello e \& CANDIDO, Antonio. A lembrança que guardo de Mário. Revista do Instituto de Estudos Brasileiros, São Paulo, 36: 9-25, 1994, p. 18.

93 Ibidem. 
Na entrada do século $X X$, o traje masculino ${ }^{94}$ já fora simplificado a fim de facilitar os movimentos, o que atingiu um ponto de cristalização, como um uniforme ${ }^{95}$ : "paletó, colete, calças estritas, sapatos ou botas, às vezes com polainas, gravata sobre o colarinho duro e, quase obrigatoriamente, chapéu" 96 .

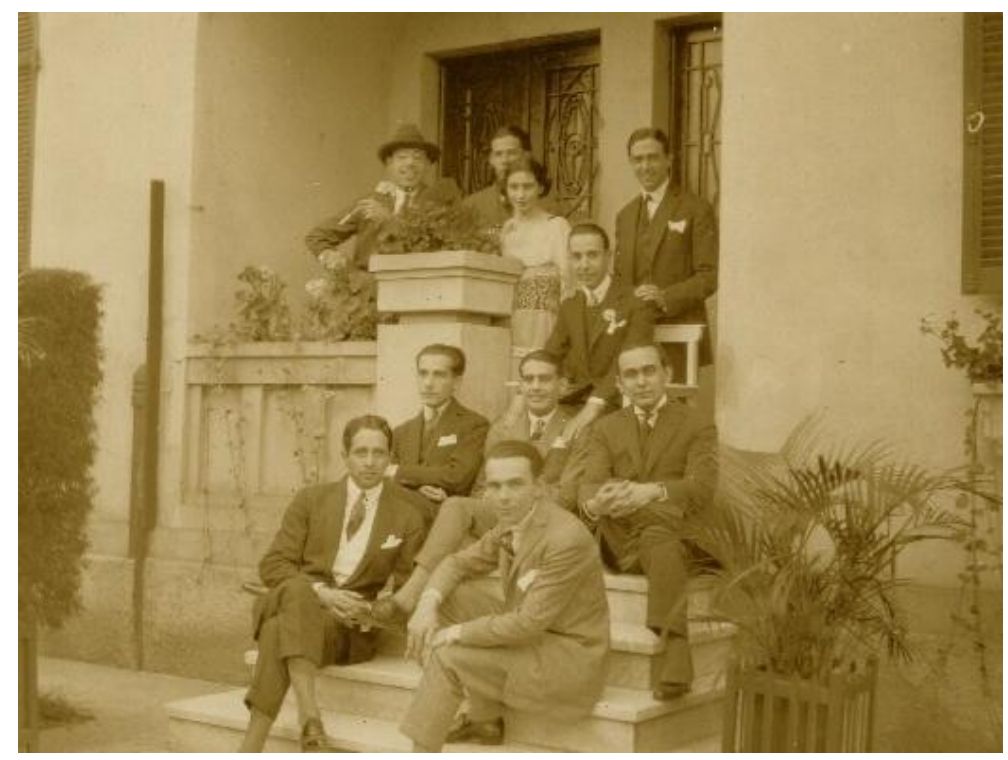

Imagem 103. A esquerda em pé, Mário de Andrade veste chapéu, com Antonio Carlos Couto de Barros, Rubens Borba de Moraes, Yan de Almeida Prado, Tácito de Almeida, em casa de Baby e Guilherme de Almeida, [1922]. É notório que quase todos os homens adornam o bolso do paletó com lenço.

Fonte: Fotografia do Fundo Mário de Andrade - Arquivo do Instituto de Estudos Brasileiros da USP.

Os ternos eram confeccionados por alfaiates em casas especializadas, como por exemplo, a Casa Primor em que encomendara "uma roupa de cassemira bem leve e 2 de brim, era branca fina, outra mais barata" ${ }^{97}$ solicitando posteriormente a Zé Bento "pagar ao Dono da Casa Primor as duas roupas que ele fez pra mim uma de $700 \$ 000$ outra de $550 \$ 000^{\prime \prime 98}$. Mário de Andrade, possivelmente, recorria a esta casa para outras encomendas como revela este recibo de 1943.

Imagem 104. Recibo da Casa Primor, datado de 4 de maio de 1943.

Fonte: ANDRADE, Mário de. A imagem de Mário: textos extraídos da obra de Mário de Andrade / [introdução, Telê Porto Ancona Lopez]. Rio de Janeiro: Edições Alumbramento, 1984, p. 53.

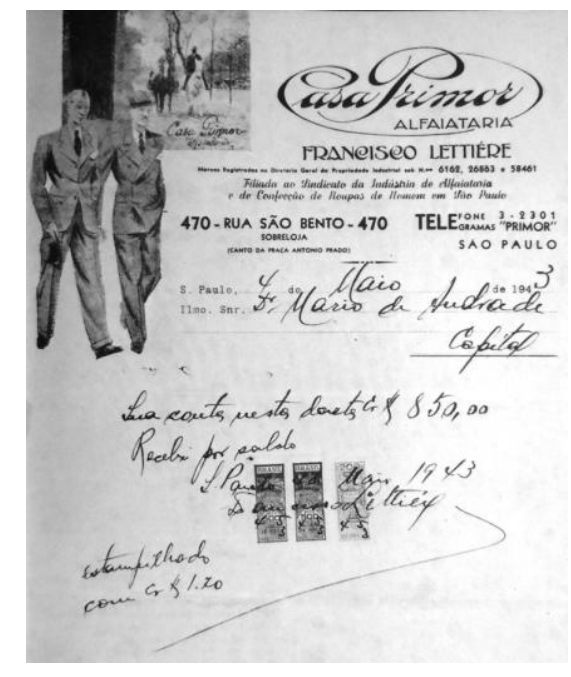

${ }^{94}$ Para saber mais, consultar: SOUZA, Gilda de Mello. O espírito das roupas: a moda no século dezenove. São Paulo: Companhia das Letras, 1987.

${ }^{95}$ Ibidem, p. 64.

${ }^{96}$ CASTELLANI, José. São Paulo na década de 30. São Paulo: Editora Policor, s.d., p. 134.

${ }^{97}$ Correspondência de Mário de Andrade a José Bento Ferraz, Rio de Janeiro, 2 de julho de 1940. Fundo José Bento Ferraz - Arquivo IEB USP.

${ }^{98}$ Correspondência de Mário de Andrade a José Bento Ferraz, Rio de Janeiro, 29 de agosto de 1940. Fundo José Bento Ferraz - Arquivo IEB USP. 
Em relação às fotos apresentadas para relacionar o colecionador e sua coleção, salta aos olhos que Mário de Andrade posa com seu robe de chambre, ou smoking de quarto ${ }^{99}$, possivelmente executado por sua mãe de acordo com projeto seu. Mário de Andrade ainda se apresentava, em sua residência, com "pijama de fundo claro e listras largas, [...] na sala de visitas de sua residência - uma casa que fica nos limites de Perdizes, Barra Funda, e Santa Cecília" ${ }^{100 .}$
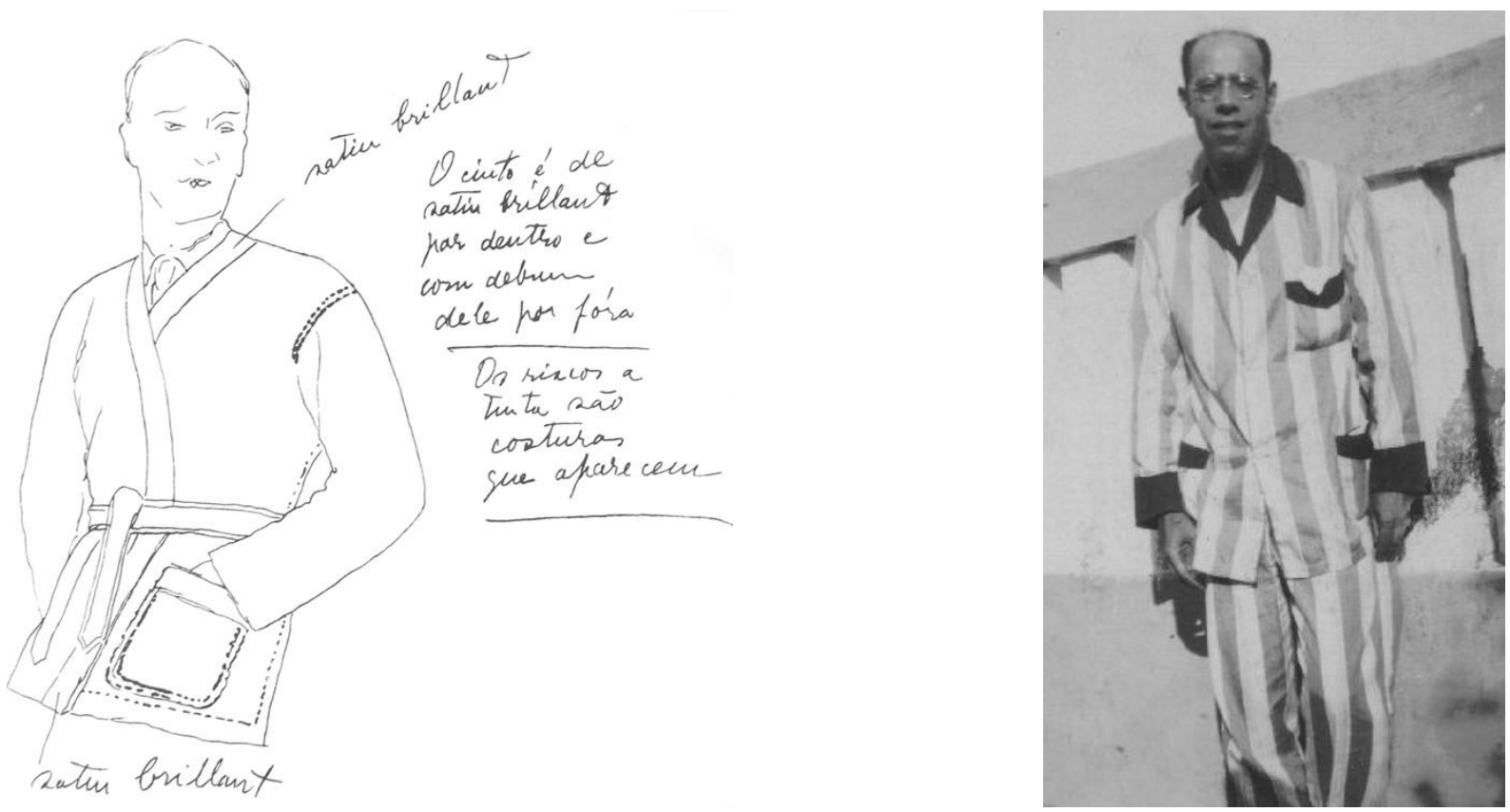

Imagem 105. Projeto do robe de chambre.

Fonte: ANDRADE, Mário de. A imagem de Mário: textos extraídos da obra de Mário de Andrade / [introdução, Telê Porto Ancona Lopez]. Rio de Janeiro: Edições Alumbramento, 1984, p. 54.

Imagem 106. Mário de Andrade de pijama em Natal, 5 jan. 1929.

Fonte: Fotografia do Fundo Mário de Andrade - Arquivo do Instituto de Estudos Brasileiros da USP.

É interessante que o robe de chambre era utilizado por intelectuais e figuras públicas, por cima da camisa e gravata, como a proteger, por um lado a roupa da rua de eventuais acidentes no ambiente doméstico, e, por outro dos possíveis contatos prejudiciais da rua que pudessem chegar para a casa. A iconografia os robes de chambre são bastante variadas e datam do século XVII.

Imagem 107. Yan de Almeida Prado em robe de chambre.

Fonte: Disponível em <http:\|www.costumes.orghistory100pages 18thpatterns.htm>. Acesso em 6 nov. 2011

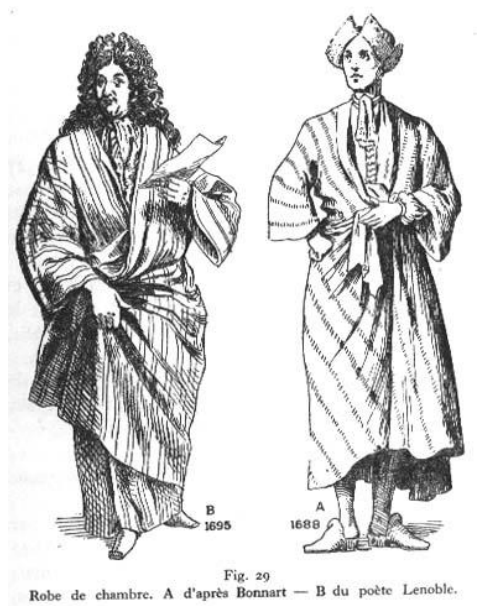

${ }^{99}$ Conforme, depoimento de Antonio Candido, a A. em 27 out. 2011.

100 ANDRADE, Mário de. Entrevistas e depoimentos. Telê Porto Ancona Lopez (org.). São Paulo: T. A. Queiroz, 1983, p. 80. 
Há exemplos de intelectuais franceses no acervo como o Museu Carnavalet, dedicado à história de Paris, em que o robe de chambre é utilizado por cima da gravata e do terno.
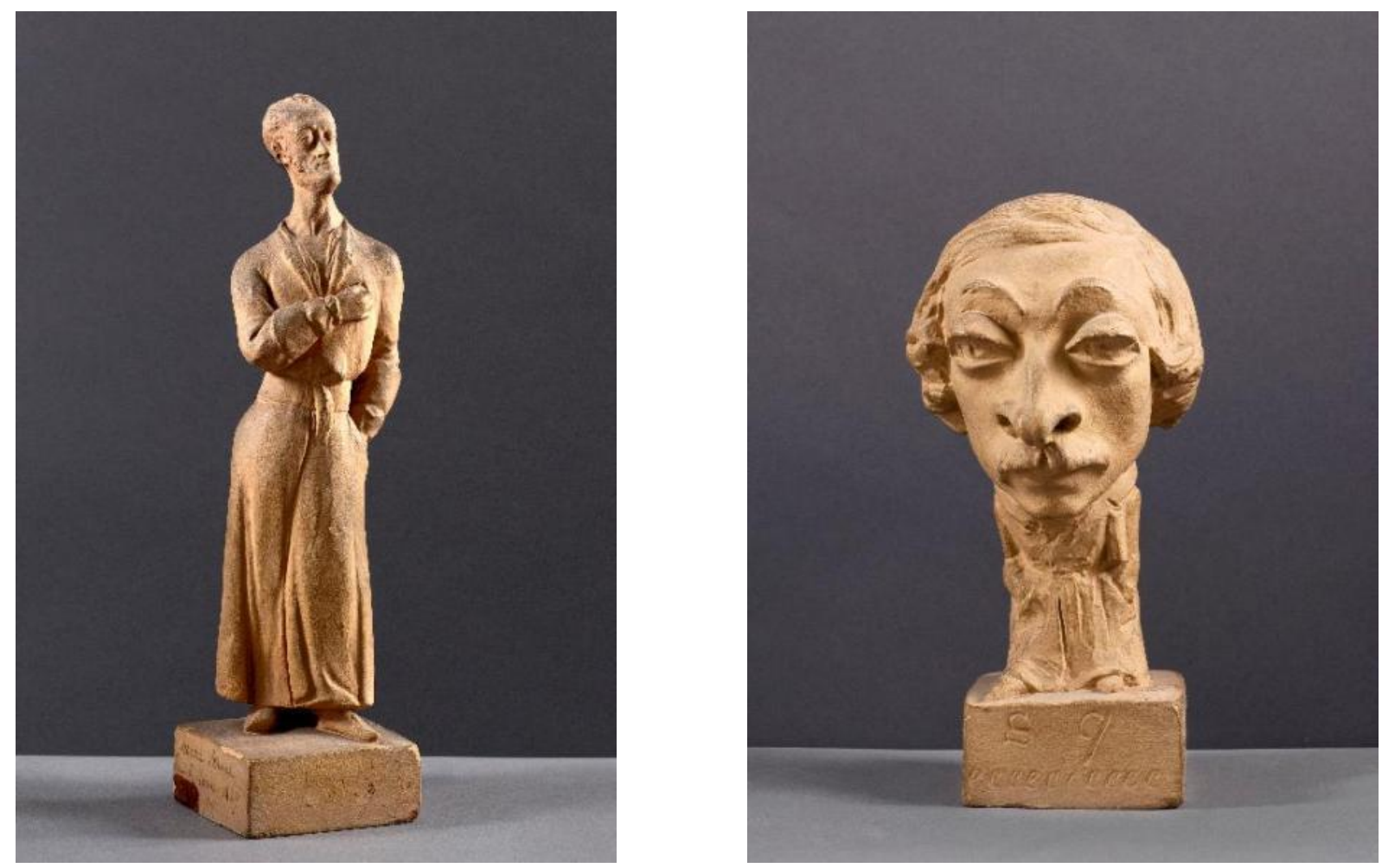

Imagem 108 e 109.. Retrato de Horace Vernet (1789-1863), editor musical e Retrato de Léon Escudier (18211881), estudioso de música. Executado por Dantan, Jean Pierre (dito Dantan Jeune), terracota, 1832 e 1841, respectivamente.

Fonte: Disponível em <http://a80-musees.apps.paris.fr/Portail/Site/Typo3.asp?lang=FR\&id=accueil>. Acesso em 06 de novembro de 2011

Manuel Bandeira enviara a seu amigo Mário de Andrade foto em que está de robe de chambre. Ou ainda o quadro que retrata Yan de Almeida Prado, dados estes que podem indicar uma prática habitual no período entre determinados segmentos, como o de intelectuais. Possivelmente estivesse aliado a um senso de sofisticação e informação, acerca das novas normas higienistas.

Imagem 110. Yan de Almeida Prado em robe de chambre. Fonte: Coleção Yan de Almeida Prado - Coleção de Artes Visuais do Instituto de Estudos Brasileiros da USP.

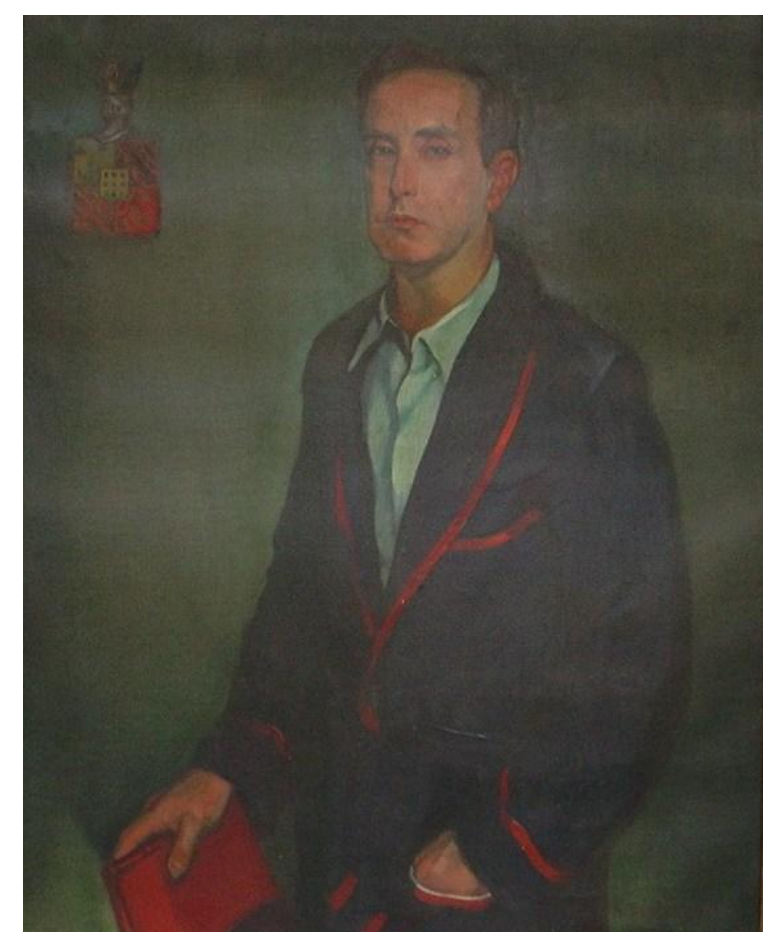



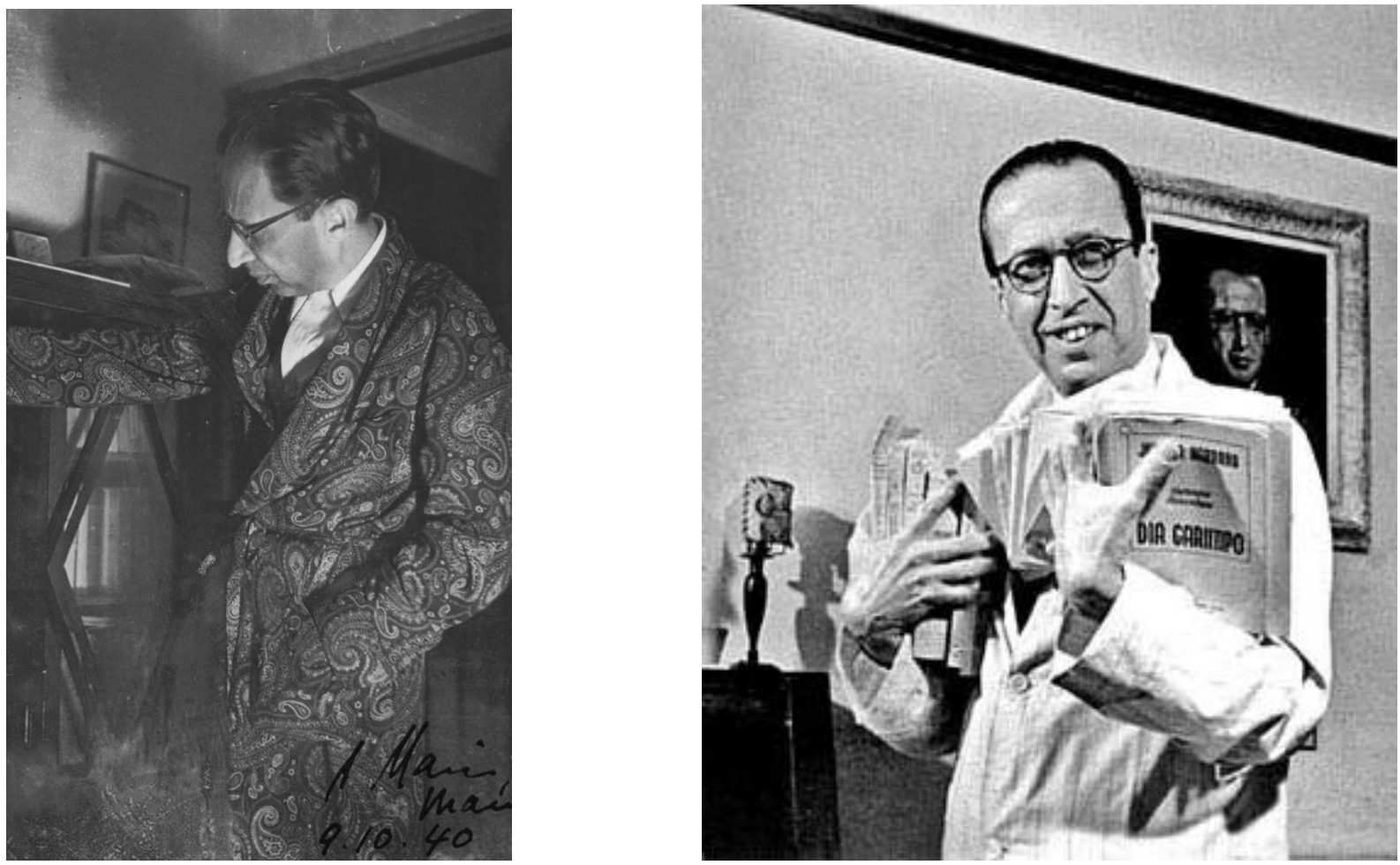

Imagem 111. Manuel Bandeira, 9 out. 1940.

Fonte: Fotografia do Fundo Mário de Andrade - Arquivo do Instituto de Estudos Brasileiros da USP.

Imagem 112. Manuel Bandeira de pijama, segurando livros, entre eles Dia Garimpo, de Julieta Bárbara lançado em 1939.

Fonte: Disponível em <http:\\ antoniolassance.blogspot.com_2011_01_01_archive.html>. Disponível em 22 jul. 2011. 

o capítulo final, Mário entre suas coisas da terra, Em seu texto sobre o Movimento Modernista (1942), Mário de Andrade ao desconfiar de seu passado, faz auto-crítica que legitima sua própria coleção de artes plásticas, ao passo que dá a medida dessa desconfiança. Se por um lado, o autor se coloca desconfiado e em dúvida, por outro são a memória material do colecionador.

Destarte, identificaram-se dois usos distintos, por Mário de Andrade: o térreo e o primeiro andar. O nível ao rés do chão estava ligado às áreas públicas da casa, que todos os moradores frequentavam, já o andar superior, como se verá adiante, dirigia-se à construção da sua imagem pública.

Dessa forma, a sala de visitas e de jantar possuíam exemplares da arte brasileira coetânea, seguindo o padrão vigente, sem irreverência na escolha. Assim, o local das refeições era decorado com paisagens e naturezas-mortas, de artistas que prezavam o bemfazer artístico, sua manufatura, seu lado artesanal, que Mário de Andrade tanto prezava ainda mais quando associado ao virtuosismo do artista e à sua bagagem cultural.

Já a sala de visitas, havia o predomínio de retratos, sejam eles de artistas modernistas, sejam de fotografias e pintura acadêmica, que se compunham com paisagens e objetos ligados ao catolicismo. Eram obras que não possivelmente não causavam tanto impacto quanto outras de sua coleção e mesmo que $A$ estudante russa trouxesse qualquer choque, a disposição dos móveis encarregava-se de deixar os visitantes sempre sentados de costas para a obra.

A saleta de piano, ambiente no qual Mário de Andrade recebia os alunos de piano, revela as multifacetas do colecionador, seja como professor e estudioso da música, seja como estimulador e membro ativo do movimento modernista; todos a demonstrar a importância dos princípios a serem atingidos pela cultura: pesquisa estética, atualização artística e consciência nacional.

Há que se notar a base cultural pretendida com as áreas intermediárias, como o vestíbulo e a escada, por um lado denota ligação com a Semana de Arte Moderna e as descobertas estéticas, tanto no campo da criação, quanto da crítica. E por outro, citações estrangeiras, como Lhote, a dar "lastro" ao colecionador, por ser artista conhecido e reconhecido internacionalmente, sendo bem vindo colocá-los aos olhos de todos os visitantes da casa.

Dessa forma, a exposição da coleção ao olhar revela que Mário de Andrade tinha um projeto de sua casa, em que o térreo destinava-se a intermediação entre os usos da família e seus desejos de colecionador. Fora justamente nos seus domínios da casa, ante-sala e escritório, que trouxe para si as suas preferências reveladas pelas escolhas junto a estes locais.

Assim, podemos concluir que para Mário de Andrade todas as marcas de sua vida de certa forma se projetavam em sua coleção. Importava-lhe tanto os arroubos da juventude, do frescor dos traços, quanto a construção da vida e até da confissão de seu sofrimento, assim como caminhos e lugares de seu viver essencialmente urbano. 
CONSIDERAÇÕES FINAIS 
estudo procurou de certa forma desnaturalizar as obras da Coleção Mário de Andrade, revendo as escolhas do intelectual à luz do que exibe, em que lugar e por que de inúmeras escolhas, que replicam hodiernamente às pesquisas, exposições e reproduções, pautadas na obra-monumento. Para isso, pretendeu-se entender o acervo como uma cultura de época, a revelar a multiplicidade de interesses de Mário de Andrade, realizada com materiais, ferramentas que o autor deixou como legado, juntamente com a construção de sua imagem para a posteridade.

Neste sentido a possibilidade de investigar, analisar e interpretar as escolhas se une ao intento de Mário de Andrade em se inserir na História e construir determinados suportes que garantam, para além da obra de arte como obra, a compreensão da coleção como um corpus que relaciona as suas partes.

Para isso, Mário de Andrade fora generoso ao ter criado um universo documental, capaz de fomentar diversos percursos de entender ao seu pensamento intelectual de forma também ampla. No caso da coleção de artes plásticas, modelava-se a outras coleções, mas não se detinha nesses limites, ao acrescentar elementos de desejos próprios e apostas inovadoras.

O caminho trilhado por este trabalho deu ênfase para a encruzilhada do vir a ser, ocasião em que colecionador deixa sua coleção para a posteridade, num estado latente de movimento das formas, ainda em sua casa com a exposição ao olhar até a incorporação pelo Instituto de Estudos Brasileiros. Este tempo intermediário dominado pelo entre permitiu traçar a relação entre a coleção e seu colecionador por meio da reconstrução do espaço.

Foram fundamentais as fontes investigativas, heterogêneas nas linguagens, semelhantes no enfoque dado ao personagem Mário de Andrade. De sua autoria, a contribuição, em textos literários e críticos e no conjunto epistolar, possibilitou perceber a coleção de artes como recurso de reflexão conectado ao pensamento do autor. De outras naturezas, curtas-metragens associados com as iconografias da casa permitiram reconstruíla muito próxima ao que fora deixado pelo colecionador levando-se em conta de que se encontrava carregada de potencialidade.

O coroamento da análise documental foi ocasionado com o depoimento do Prof. Antonio Candido que elucidara questões próprias desta pesquisa, a partir da sua vivência no ambiente da Lopes Chaves. Nesse sentido, é de semelhante importância o testemunho da Prof.a. Gilda de Mello e Souza, que morara na casa. Ambas as contribuições revelaram aspectos que não foram registrados pelas fontes imagéticas, justamente o movimento que associa as questões do tempo e do espaço.

Para Mário de Andrade, como para outros, o estalo inicial em colecionar fora obras que o emocionassem, sedimentando-se na busca pela pesquisa estética, atualização artística e consciência nacional. O colecionador acompanha, em sua coleção de artes, a produção artística dos diversos momentos que identifica do movimento modernista, que guardam em comum seu traço destruidor, para culminar na fase seguinte a primazia do bem-fazer artístico, da operosidade e da construção após a devastação causada pelo momento anterior. Tal senso crítico constitui diferencial, que ultrapassa o gosto para ser documento de época.

As escolhas de Mário de Andrade levaram a atingir o prestígio e o reconhecimento de sua coleção desde sua formação, que trouxe consigo os problemas típicos da salvaguarda de 
acervo, que podem variar no como, mas cuja essência se mantem de maneira muito semelhante até os dias hodiernos.

A reconstituição das obras expostas ao olhar revela os preceitos norteadores da coleção de obras de arte, a começar pelos compromissos com a casa da família, com usos eminentemente ao convívio familiar, que se adaptavam à nova visualidade sem, contudo, abandonar por completo os fortes esquemas de decoração pré-existente no século XIX. É justamente nos espaços de domínio, que Mário de Andrade exerceu seu cabedal intelectual, potencializando a incorporação das mudanças visuais da arte.

O entrelaçamento de diversos aspecto do material coletado permitiu perceber a intenção deliberada de Mário de Andrade em consolidar o movimento moderno, associada em construir e afirmar sua própria imagem para a posteridade, que culminou na destinação pública das coisas da terra para a Universidade, estribada no tripé cultura, ensino e pesquisa.

A simbiose erigida entre Acervo e Universidade cujo funcionamento permite viver com vantagens recíprocas caracteriza-os como corpus integrado. Assim, o movimento é de mão dupla, sem qualquer hierarquização: a prática do ensino e o fomento à pesquisa dão elementos para o enriquecimento do Acervo, ao mesmo tempo em que a cultura material delineia possibilidades infindáveis de pesquisa e de formação de cidadãos. 
REFERÊNCIAS BIBLIOGRÁFICAS 


\section{Livro}

ALMEIDA, Paulo Mendes de. De Anita ao Museu. São Paulo: Perspectiva, 1976.

ALVARENGA, Oneyda. Mário de Andrade, um pouco. Rio de Janeiro/São Paulo: J. Olympio/Conselho Estadual de Cultura, 1974.

AMARAL, Amaral. Artes plásticas na Semana de 22: subsídios para uma história da renovação das artes no Brasil. São Paulo: Perspectiva, 1970.

. Artes plásticas na Semana de 22. São Paulo: Bovespa, 1992.

. Tarsila: sua obra e seu tempo. 3ed. São Paulo: 34;Edusp, 2003.

Arte para quê? A preocupação social na arte brasileira: 1930-1970. 3 ed. São Paulo: Nobel; Itaú Cultural, 2003.

ANDRADE, Oswald de. Um homem sem profissão: memórias e confissões - sob as ordens de mamãe. 2a ed. São Paulo: Globo, 2002.

ARAUJO, Marcelo Mattos. Os modernistas na Pinacoteca: o museu entre a vanguarda e a tradição. São Paulo: FAU-USP, 2002. (tese de doutorado)

BAUDRILLARD, Jean. O sistema de objetos. São Paulo: Perspectiva, 2000.

BATISTA, Marta Rossetti. Anita Malfatti no tempo e no espaço. 1 ed. São Paulo: 34, 2006, 2 vol.

Bandeiras de Brecheret: história de um monumento (1920-1953). São Paulo: Departamento do Patrimônio Histórico, 1985. . Brasil: 1o tempo modernista - 1917-1929 - documentação. São Paulo: IEB-USP, 1972.

. O crítico e o colecionador. Memória. Ano V. $\mathrm{n}{ }^{0} 17$. São Paulo: Departamento de

Patrimônio Histórica da Eletropaulo, jan/fev./mar. de 1993. . Centenário de nascimento: Victor Brecheret (1894-1955). São Paulo: IEB-USP, 1994.

BENJAMIN, Walter. A obra de arte na era da sua reprodutibilidade técnica. In: Magia e técnica, arte $e$ política: ensaios sobre a literatura e fistória da cultura. São Paulo: Brasiliense, 1994.

BLOM, Phillip. Ter e manter: uma história íntima de colecionadores e coleções. Rio de Janeiro: Record, 2003.

BRADBURY, M. Modernismo guia: geral 1890-1930. São Paulo: Cia. das Letras, 1989.

BRANDI, Cesare. Teoria del restauro. Torino: Eunaudi, 2000.

CALDEIRA, João Ricardo. IEB: origem e significados - uma análise do Instituto de Estudos Brasileiros da Universidade de São Paulo. São Paulo: Oficina do livro Rubens Borba de Moraes / Imprensa Oficial, 2002.

CAMARGOS, Marcia. Villa Kyrial: crônica da Belle Époque paulistana. 2ª ed. São Paulo: Editora SENAC, 2001.

CARVALHO, Vânia Carneiro de. Gênero e Artefato: o sistema doméstico na perspectiva da cultura material - São Paulo, 1870-1920. São Paulo: Edusp / FAPESP, 2008.

CHATEAUBRIAND, Assis. Na cidade de Pereira Ignácio e de Francisco Matarazzo. In: MATTAR, Denise (org.). No tempo dos modernistas D. Olivia Penteado, a Senhora das Artes. São Paulo: MAB FAAP, 2002.

COLI, Jorge; DANTAS, Luiz Carlos da Silva. Sobre O Banquete. In: ANDRADE, Mário. O Banquete. São Paulo: Duas Cidades, 1977. 
D'ALMEIDA, Alfredo Dias. Caravana Farkas (1968/1970): a cultura popular (re)interpretada pelo filme documentário - um estudo de folkmídia. São Paulo, 2003. Dissertação de Mestrado São Paulo: Universidade Metodista.

D’HORTA, Vera. MAM - Museu de Arte Moderna de São Paulo. São Paulo: DBA, 1985.

ECO, Umberto. Como se faz uma tese. 18 ed. São Paulo: Perspectiva, 2002.

FERRARI, Elly Rozo. Escritura de uma exposição: diálogos de uma educadora e acervos pessoais. São Paulo: FE USP, 2010. (tese de doutorado)

GARCEZ MARINS, Paulo César. Habitação e vizinhança: limites da privacidade no surgimento das metrópoles brasileiras. In: História da vida privada no Brasil - República: da Belle Époque à Era do Rádio. NOVAIS, Fernando (org. geral). SEVCENKO, Nicolau (org. do volume). São Paulo: Companhia da Letras, 1998.

GOMES, Paulo Emilio Salles. 10 anos de filmes sobre arte. São Paulo: Filmoteca III Bienal Museu de Arte Moderna de São Paulo, 1955.

HALBWACHS, Maurice. A Memória coletiva. Tradução de Beatriz Sidou. São Paulo: Centauro, 2006.

HERKENHOFF, Paulo. Arte brasileira na coleção Fadel: da inquietação do moderno à autonomia da linguagem. Rio de Janeiro: Andrea Jakobson, 2002.

LOURENÇO, Maria Cecília França. Museus acolhem o Moderno. São Paulo: Edusp, 1999. . Operários da Modernidade. São Paulo: Hucitec; Edusp, 1995.

Transformação do moderno em cultura urbana. In.: Cadernos de História de São Paulo São Paulo: novas fontes, abordagens e temáticas. São Paulo: Museu Paulista da Universidade de São Paulo, n. 5, 1996, p. 8.

MARTINS, Ana Luisa \& SILVA, José Armando Pereira da. Luís Martins: um cronista de arte em São Paulo nos anos 1940. São Paulo: MAM, 2009.

MATTAR, Denise (org.). No tempo dos modernistas D. Olivia Penteado, a Senhora das Artes. São Paulo: MAB FAAP, 2002.

MICELI, Sergio. Imagens negociadas: retratos da elite brasileira (1920-40). São Paulo: Cia. das Letras, 1996.

Nacional estrangeiro: história social e cultural do modernismo artístico em São Paulo. São Paulo: Cia. das Letras, 2003.

MOTTA, Flávio. A Família Artística Paulista. Revista do Instituto de Estudos Brasileiros, São Paulo, 10: 137-175, 1971.

MUSEU de Arte Contemporânea da Universidade de São Paulo. São Paulo: Banco Safra, 1990.

NASCIMENTO, Ana Paula. Espaços e a representação de uma nova cidade: São Paulo (1895-1929). São Paulo: FAU USP, 2009. (tese de doutorado)

NORA, Pierre. Entre a memória e a história: a problemática dos lugares. Projeto História (10): 7-28, dez. 1993.

PEDROSA, Mário. Dos murais de Portinari aos espaços de Brasília. Aracy A. Amaral (org.). São Paulo: Perspectiva, 1981.

Obras completas: textos escolhidos I, II, III e IV. Otilia Beatriz Fiori Arantes (org.). São Paulo: Edusp, 2000

PICCININI, Daisy. Brecheret: a linguagem das formas. São Paulo: Instituto Victor Brecheret, 2004.

POMIAN, Krzysztof. Coleção. Enciclopédia Einaudi. Lisboa: Einaudi, 1985. Vol I História-Memória. 
RAFFAINI, Patrícia Tavares. Esculpindo a cultura na forma Brasil: o Departamento de Cultura de São Paulo (1935-1938). São Paulo: Humanitas; FFLCH-USP, 2001.

RIBEIRO, Maria Izabel Meirelles Branco. O museu doméstico - São Paulo 1890-1920. São Paulo: ECAUSP, 1992. (dissertação de mestrado)

SCHWARTZMAN, S. Tempos de Capanema. São Paulo: Edusp/ Rio de Janeiro: Paz e Terra, 1984.

TELES, Gilberto. Vanguarda européia e modernismo brasileiro: apresentação dos principais poemas, manifestos, prefácios e conferências vanguardistas, de 1857-1972. 18 ed. Petrópolis: Vozes, 2005.

\section{De Mário de Andrade}

AMARAL, Aracy (org.). Correspondência: Mário de Andrade e Tarsila do Amaral. São Paulo: Edusp; IEB-USP, 2001.

ANDRADE, Mário de. Crônica de Malazarte I. América Brasileira, Rio de Janeiro, out. 1923.

. A lição do amigo: cartas de Mário de Andrade a Carlos Drummond de Andrade anotadas pelo destinatário. Rio de Janeiro: José Olympio, 1982.

Entrevistas e depoimentos. Telê Porto Ancona Lopez (org.). São Paulo: T. A.Queiroz, 1983.

. Aspectos da literatura brasileira. São Paulo: Martins Editora, 1957.

. Aspectos das artes plásticas no Brasil. São Paulo: Martins, 1965.

. A Biblioteca Lamego. In: Coleção Alberto Lamego: catálogo dos manuscritos. 2a ed. São

Paulo: IEB USP, 2002.

. Carta ao pintor moço. São Paulo: Boitempo Editorial, 1995.

. Cartas a Manuel Bandeira. Rio de Janeiro: Simões, 1958.

. Cartas a Murilo Miranda. Rio de Janeiro: Nova Fronteira, 1981.

. Cartas de Mário de Andrade a Álvaro Lins. Rio de Janeiro: José Olympio, 1983.

. Cartas de Mário de Andrade a Prudente de Moraes Neto: 1924 - 1934. Rio de Janeiro: Nova Fronteira, 1985.

. Cartas de trabalho: correspondência com Rodrigo Mello Franco de Andrade (1936 - 1945).

Brasília: Ministério da Educação e Cultura, 1981.

. Correspondente contumaz: cartas a Pedro Nava, 1925-1944. Rio de Janeiro: Nova Fronteira, 1982.

. De Paulicéia Desvairada a Café (poesias completas). São Paulo: Círculo do Livro, s/d.

. Macunaíma: o herói sem nenhum caráter. 32 ed. Belo Horizonte: Livraria Garnier, 2001.

- Mário de Andrade e $(m)$ Campos dos Goitacazes: cartas de Mário de Andrade a Alberto Lamego: 1935-1938. Niterói: Eduff, 1992.

. Mario de Andrade, Oneyda Alvarenga: cartas. São Paulo: Duas Cidades, 1983.

. Mário e o pirotécnico aprendiz: cartas de Mário de Andrade e Murilo Rubião. São Paulo:

IEB-USP/ Belo Horizonte: Giordano; UFMG, 1995.

. O banquete. São Paulo: Duas Cidades, 1977.

. O Movimento Modernista. In.:Aspectos da literatura brasileira. 6 ed. Belo Horizonte:

Editora Itatiaia, 2002 (Conferência lida no Salão de Conferências da Biblioteca do Ministério das

Relações Exteriores do Brasil, no dia 30 de abril de 1942, Casa do Estudante do Brasil, Rio de Janeiro). 
O turista aprendiz. São Paulo: Duas Cidades;Secretaria da Cultura, Ciência e Tecnologia, . Os filhos de Candinha. 3 ed. São Paulo: Martins/ Brasília: INL, 1976.

. Paulicea Desvairada. São Paulo: Casa Mayença, 1922.

Vida literária. São Paulo: Hucitec, 1993.

AMARAL, Aracy (org.). Correspondência Mário de Andrade \& Tarsila do Amaral. São Paulo: Edusp; IEB, 2001. (Coleção Correspondência de Mário de Andrade, 2)

BATISTA, Marta Rossetti (org.). Mário de Andrade: cartas a Anita Malfatti: 1921-1939. Rio de Janeiro: Forense Universitária, 1989.

CANDIDO, Antonio (org.) PIO \& MÁRIO: diálogo da vida inteira. A correspondência entre o fazendeiro Pio Lourenço Corrêa e Mário de Andrade. Antonio Candido (traços biográficos); Gilda de Mello e Souza (introdução); Denise Guaranha (texto e notas); Tatiana Longo Figueiredo (texto, datas e revisão ortog.). Rio de Janeiro/São Paulo: Ouro sobre Azul/ SESC-SP, 2009.

FABRIS, Annateresa (org.). Portinari, amico mio: cartas de Mário de Andrade a Portinari. Campinas: Mercado de Letras, Autores Associados /Rio de Janeiro: Projeto Portinari, 1995.

FERNANDES, Lygia (org.). Mário de Andrade escreve: cartas a Alceu, Meyer e outros. Rio de Janeiro: Editora do Autor, 1968.

LOPEZ, Telê Ancona. De São Paulo: cinco crônicas de Mário de Andrade, 1920-1921. São Paulo: Senac, 2004.

. Imagem de Mário de Andrade: fotobiografia de Mário de Andrade. Rio de Janeiro: Edições Alumbramento, 1984. 1976.

(org.). Mário de Andrade: Táxi e crônicas no Diário Nacional. São Paulo: Duas Cidades,

MORAES, Marcos Antônio de (org.). Correspondência: Mário de Andrade \& Manuel Bandeira. 2 ed. São Paulo: Edusp; IEB, 2001. (Coleção Correspondência de Mário de Andrade, 1)

Guaranha (texto e notas). Tatiana Longo Figueiredo (texto, datas e revisão ortog.). Rio de Janeiro / São Paulo: Ouro sobre Azul / SESC-SP, 2009.

\section{Sobre Mário de Andrade}

ALVARENGA, Oneyda. Mário de Andrade, um pouco. Rio de Janeiro: José Olympio/ São Paulo: Conselho Estadual de Cultura, 1974.

AVANCINI, José Augusto. Expressão plástica e consciência nacional na crítica de Mário de Andrade. Porto Alegre: UFRGS, 1998.

BATISTA, Marta Rossetti e LIMA, Yone Soares de. Coleção Mário de Andrade: artes plásticas. 2a ed. São Paulo: IEB-USP, 1998.

BATISTA, Marta Rossetti. Cem obras-primas da Coleção Mario de Andrade: pintura e escultura. São Paulo: IEB-USP, 1993. (Catálogo de exposição)

$$
2004 .
$$

Coleção Mário de Andrade: religião e magia, música e dança, cotidiano. São Paulo: Edusp,

BERRIEL, C. Mário de Andrade hoje. São Paulo: Ensaio, 1990.

BORBA, Rubens Borba de. O engenheiro, o bibliotecário e o sentido de um projeto cultural. Revista da Biblioteca Mário de Andrade. São Paulo 50: 54-59, 1992.

CASTRO, M. Mário de Andrade: exílio no Rio. Rio de Janeiro: Rocco, 1989. 
DUARTE, Paulo. Mário de Andrade por ele mesmo. São Paulo: Hucitec; Secretaria da Cultura, Ciência e Tecnologia do Estado de São Paulo, 1977.

EDIÇÃO comemorativa dos 50 anos da Biblioteca Mário de Andrade. Revista da Biblioteca Mário de Andrade (50), São Paulo, 1992.

FACCIOLI, Valentim. Mário de Andrade e a cidade de São Paulo: aspectos. In: Revista da Biblioteca Mário de Andrade. São Paulo, 50:62-79.

IONTA, M. As cores da amizade: cartas de Anita Malfatti, Oneyda Alvarenga, Henriqueta Lisboa e Mário de Andrade. 1 ed. São Paulo: Fapesp / Annablume, 2007.

LOPEZ, Telê Ancona. A imagem de Mário: fotobiografia de Mário de Andrade. Rio de Janeiro: Alumbramento, 1998.

. Eu sou trezentos, eu sou trezentos e cincoenta. Rio de Janeiro: Agir, 2008.

. Eu sou trezentos, sou trezentos-e-cincoenta: uma autobiografia de Mário de Andrade. São

Paulo: Centro Cultural São Paulo, 1992. (catálogo de exposição)

. Mário de Andrade: ramais e caminho. São Paulo: Duas Cidades, 1972.

MÁRIO de Andrade: diretor do Departamento de Cultura de São Paulo. São Paulo: CCSP, 2003. (catálogo de exposição)

MARTINS, Justino. Presença e Ausência de Mário de Andrade. Ed. Keffel (fotografias). Revista do Globo. Porto Alegre, 23 fev. 1946.

MORAES, Marcos Antonio de (org.). "Tudo está tão bom, tão gostoso..." postais a Mário de Andrade. São Paulo: Hucitec; Edusp, 1993.

Orgulho de jamais aconselhar: a epistografia de Mário de Andrade. São Paulo: Edusp; Fapesp, 2007.

MORAES, R. Lembrança de Mário de Andrade: 7 cartas. São Paulo: Teixeira, 1979.

MOTTA, Flávio L. (org.). Depoimentos 2/ Mário de Andrade. São Paulo: Grêmio FAU-USP, 1966.

POHLIT, Claudéte I. Kronbauer. Mário de Andrade: cronista crítico das artes plásticas. São Paulo: FFLCH-USP, 1996. (dissertação de mestrado).

Revista do Arquivo Municipal [Edição comemorativa dos 45 anos da morte de Mário de Andrade] (198), São Paulo, 1990.

Revista do Patrimônio Histórico e Artístico Nacional - Mário de Andrade (30), Brasília, 2002.

SOUZA, Gilda de Mello e \& CANDIDO, Antonio. A lembrança que guardo de Mário. Revista do Instituto de Estudos Brasileiros, São Paulo, 36: 9-25, 1994, p. 10.

. Homenagem a Mário de Andrade: o colecionador e a coleção. In: BATISTA, Marta

Rossetti e LIMA, Yone Soares de. Coleção Mário de Andrade. Artes Plásticas. São Paulo: IEB USP, 1984.

\section{Catálogos}

CALIL, Carlos Augusto. Mário de Andrade: diretor do Departamento de Cultura. São Paulo: Centro Cultural São Paulo, 2003.

MONTEIRO, Paulo. Exposição Sérgio Milliet e as Bienais. São Paulo: Centro Cultural São Paulo, 2006.

UNIVERSIDADE de São Paulo. Instituto Estudos Brasileiros. Histórico - organização e realizações 1963/1976 / Instituto de Estudos Brasileiros, Universidade de São Paulo. São Paulo: IEB, 1976. 
BATISTA, Marta Rossetti. Centenários Modernistas I: Wilhelm Haarberg (1891 - 1986). São Paulo: Coleção de Artes Visuais IEB USP, 22 maio a 5 jul. 1991.

\section{Obras de Referência}

ARGAN, Giulio Carlo. História da arte como história da cidade. São Paulo: Martins Fontes, 1995.

BATISTA, Marta Rossetti (coord.). ABC do IEB: guia do acervo. São Paulo: Edusp, 1997.

CONSELHO Internacional de Arquivos. ISAD(G): Norma geral internacional de descrição arquivística: 2a ed., adotada pelo Comitê de Normas de Descrição, Estocolmo, Suécia, 19-22 de setembro de 1999, versão final aprovada pelo CIA. Rio de Janeiro: Arquivo Nacional.

NOGUEIRA, Arlinda Rocha; BELLOTO, Heloísa Liberalli; HUTTER, Lucy Maffei; CARDOSO, Maria Cecília de Castro. Coleção Alberto Lamego: catálogo dos manuscritos. 2a ed. São Paulo: IEB USP, 2002.

ZANINI, Walter (coord.). História geral da arte no Brasil. São Paulo: Instituto Moreira Salles / Fundação Djalma Guimarães, 1983.

\section{Sítios consultados}

Museu Antônio Parreiras. Disponível em: <http://www.museusdoestado.rj.gov.br/map/ colecoes4.htm>. Acesso em: 24 jan. 2012.

Sítio da casa-museu Casa de Cultura Euclides da Cunha, São José do Rio Pardo. Disponível em <http://casaeuclidiana.org.br>. Acesso em 25 jan. 2012.

Guia trabalhista. Disponível em: < http:// www.guiatrabalhista.com.br/guia /salario_minimo_1940a1999.htm>. Acesso em: 25 jan. 2012

MANGUE. Rio de Janeiro: Editora Revista Acadêmica, 1943. Álbum contendo 42 reproduções de desenhos originais de Segall, impressos em zincografia, 3 xilogravuras e 1 litografia originais, assinadas pelo artista. Textos de Jorge de Lima, Mário de Andrade e Manuel Bandeira. Disponível em < http:// www.museusegall.org.br/mlsTexto.asp?sSume=13>. Acesso em 25 jan. 2012.

Museum of Modern Art (New York, NY). Portinari of Brazil, 8 out.-17 nov. 1940. [individual 186 obras]. Disponível em <http://www.portinari.org.br/ppsite/ppacervo/ listaevesTipo.asp\#>. Acesso 25 fev. 2012.

Coleção Oscar Americano. <http://www.fundacaooscaramericano.org.br/ fundacao20a.html>. Acesso em 06 fev. 2012.

Leilão da obra La tasse de thé, de Fernand Léger, em 2010. Disponível em <http://www.christies.com/features/fernand-leger-la-tasse-de-the-1093-3.aspx>. Acesso em 05 fev. 2012.

Obra Champs de Mars: La Tour Rouge, de Delaunay, pertencente ao acervo de The Art Institute of Chicago,. Disponivel em <http://www.artic.edu/aic/collections/artwork/ 9503?search_id=1>. Acesso em 04 fev. 2012.

Museu da Energia de São Paulo. Disponível em <http://www.energiaesaneamento.org.br/ redemuseuenergia/edificio.php?id=1>. Acesso em 05 fev. 2012. 
Musée Fabre de Montpellier, ocorreu a exposição "Rugbysme, le rugby et l'art moderne". Disponível em <http://museefabre.montpellier-agglo.com/ index.php/ visiter/ les_expositions/rugbysme_le_rugby_et_I_art_moderne>. Acesso em 06 nov 2011.

MARTÍ. Silas. Quadro que pertenceu a Mário de Andrade vai a leilão em Nova York. Folha de São Paulo. São Paulo, 06 maio 2011. Disponível em < http://www1.folha.uol.com.br /ilustrada/ 910180-quadro-que-pertenceu-a-mario-de-andrade-vai-a-leilao-em-novayork.shtml>. Acesso em 10 set. 2011.

HUMBERT, Frederic. Art \& Rugby at Sotheby's. Disponível em <http://rugbypioneers.blogs.com/rugby/ 2011/07/art-rugby-at-sothebys.html>. Acesso em 22 fev. 2011. CORRÊA, Angelo Mendes Corrêa. Entrevista concedida a Roniwalter Jatobá, nos anos de 1990. Disponível em <http://www.verbo21.com.br/v5/ index.php?option= com_content\&view= article\&id=362: mario-de-andrade - e - jose-bento-ferraz - angelomendes-correa \& catid=64: resenha-e-ensaios-junho-2011\&ltemid=127>. Acesso em 05 fev. 2012.

\section{Filme}

A CASA de Mário de Andrade. SANTOS, Ruy (direção); SOUZA, Gilda de Mello (argumento e roteiro). São Paulo: Rangel Filmes Ltda, 1955. 35 mm, bp, 21 min, 561 m, 24 q. SIWACZENKO, Konstantyn (som); GUARNIERI, Camargo (música Sinfonia no 3); FORSTER, Walter (narração). Cópia deste filme pertence ao acervo filmográfico da Cinemateca Brasileira - Centro de Documentação e Pesquisa - Biblioteca Paulo Emilio Salles Gomes.

Casa de Mário de Andrade. SARNO, Geraldo (direção). FARKAS, Thomaz (fotografia). São Paulo: Departamento de Produção de Filmes Documentários do Instituto de Estudos Brasileiros da Universidade de São Paulo, 1968. Cópia deste filme pertence ao Serviço de Arquivo do Instituto de Estudos Brasileiros da USP.

\section{Documentação}

\section{Correspondência do Fundo Mário de Andrade}

Carta de apresentação de Affonso D'Escragnolle Taunay apresentando Mario de Andrade a Alberto Lamego para as tratativas para a incorporação do acervo deste à Universidade de São Paulo. C, 17 out. 1935. Fundo Mário de Andrade, código de referência: MA-C-CPL6638. Correspondência de Alberto Lamego a Mário de Andrade. Campos dos Goitacazes, 20 maio 1936. Fundo Mário de Andrade, código de referência: MA-C-CPL3885.

Carta a Henriqueta Lisboa de 2 de julho de 1941. Cópia xerografada existente no Fundo Mário de Andrade do Arquivo do IEB-USP.

Carta de Victor Brecheret a Mário de Andrade, [Paris], [1926], código de referência: MA-CCPL1486.

Correspondência de Victor Brecheret a Mário de Andrade. Paris, 19 ago. 1922. Fundo Mário de Andrade, códigos de referências: MA-C-CPL1479.

Correspondência de Victor Brecheret a Mário de Andrade, [Paris], [1923]. Fundo Mário de Andrade, códigos de referências: MA-C-CPL1480. 
Correspondência de Mário de Andrade a José Bento Ferraz, Rio de Janeiro, 23 de outubro de 1939. Fundo José Bento Ferraz - Arquivo IEB USP. Referencia

Correspondência de Mário de Andrade a José Bento Ferraz, Rio de Janeiro, 10 de agosto de 1938. Fundo José Bento Ferraz - Arquivo IEB USP. Referencia

Correspondência de Mário de Andrade a José Bento Ferraz, Rio de Janeiro, 2 de julho de 1938. Fundo José Bento Ferraz - Arquivo IEB USP.

Carta de Maria de Lourdes de Andrade Camargo a Mário de Andrade. São Paulo, 03 set. 1938. Fundo Mário de Andrade, código de referência: MA-C-CPL1568.

Correspondência de Mário de Andrade a José Bento Ferraz, Rio de Janeiro, 10 de agosto de 1938. Fundo José Bento Ferraz - Arquivo IEB USP.

Correspondência de Murilo Miranda a Mário de Andrade. Rio de Janeiro, [ant. 12 mar. 1936]. Fundo Mário de Andrade, código de referência: MA-C-CPL4999.

Correspondência de Mário de Andrade a Murilo Miranda. São Paulo, 12 mar. 1936. Fundo Mário de Andrade, código de referência: MA-C-CPR364.

Correspondência ilustrada de Victor Brecheret a Mário de Andrade. Paris, 14 maio 1924. Coleção Mário de Andrade, da Coleção de Artes Visuais do IEB USP, código de referência: MA-0131.

\section{Documentos não publicados}

MALFATTI, Anita. A chegada da arte moderna. Manuscrito Fundo Anita Malfatti - Arquivo IEB-USP.

ANDRADE, Mário de. O artista e o artesão. Aula inaugural dos cursos de Filosofia e História da Arte, do Instituto de Artes, da Universidade do Distrito Federal em 1938. São Paulo: Centro de Estudos Folclóricos do Gfau, 1955. (Mimeogr.).

\section{Processo}

Processo USP 1967.1.107.31.8.

\section{Filme}

A CASA de Mário de Andrade. SANTOS, Ruy (direção); SOUZA, Gilda de Mello (argumento e roteiro). São Paulo: Rangel Filmes Ltda, 1955. 35 mm, bp, 21 min, 561 m, 24 q. SIWACZENKO, Konstantyn (som); GUARNIERI, Camargo (música Sinfonia no 3); FORSTER, Walter (narração). Cópia deste filme pertence ao acervo filmográfico da Cinemateca Brasileira - Centro de Documentação e Pesquisa - Biblioteca Paulo Emilio Salles Gomes.

Casa de Mário de Andrade. SARNO, Geraldo (direção). FARKAS, Thomaz (fotografia). São Paulo: Departamento de Produção de Filmes Documentários do Instituto de Estudos Brasileiros da Universidade de São Paulo, 1968. Cópia deste filme pertence ao Serviço de Arquivo do Instituto de Estudos Brasileiros da USP.

\section{Entrevista}

Depoimento de Antonio Candido, a A. em 27 out. 2011. 